GUILHERME BARBOSA DE CASTRO

AVALIAÇÃO DA INFLUÊNCIA DAS CONDIÇÕES GEOTÉCNICAS E CLIMÁTICAS NO COMPORTAMENTO HIDROMECÂNICO DE UM SUBLEITO FERROVIÁRIO

São Paulo

2019 
GUILHERME BARBOSA DE CASTRO

\section{AVALIAÇÃO DA INFLUÊNCIA DAS CONDIÇÕES GEOTÉCNICAS E CLIMÁTICAS NO COMPORTAMENTO HIDROMECÂNICO DE UM SUBLEITO FERROVIÁRIO}

Dissertação apresentada à Escola Politécnica da Universidade de São Paulo para obtenção do título de Mestre em Ciências.

São Paulo 


\section{AVALIAÇÃO DA INFLUÊNCIA DAS CONDIÇÕES GEOTÉCNICAS E CLIMÁTICAS NO COMPORTAMENTO HIDROMECÂNICO DE UM SUBLEITO FERROVIÁRIO}

Dissertação apresentada à Escola Politécnica da Universidade de São Paulo para obtenção do título de Mestre em Ciências.

Área de concentração:

Engenharia de Transportes

Orientador:

Prof. ${ }^{\text {a }}$ Dr. ${ }^{\text {a }}$ Rosângela dos Santos Motta 
Autorizo a reprodução e divulgação total ou parcial deste trabalho, por qualquer meio convencional ou eletrônico, para fins de estudo e pesquisa, desde que citada a fonte.

Este exemplar foi revisado e corrigido em relação à versão original, sob responsabilidade única do autor e com a anuência de seu orientador.

São Paulo, de de

Assinatura do autor:

Assinatura do orientador:

\section{Catalogação-na-publicação}

Castro, Guilherme

Avaliação da influência das condições geotécnicas e climáticas no comportamento hidromecânico de um subleito ferroviário / G. Castro -- versão corr. -- São Paulo, 2019.

$184 \mathrm{p}$.

Dissertação (Mestrado) - Escola Politécnica da Universidade de São Paulo. Departamento de Engenharia de Transportes.

1.Ferrovias (infraestrutura) 2.Solo não saturado 3.Influência climática 4.Umidade do solo 5.Infiltração superficial I.Universidade de São Paulo. Escola Politécnica. Departamento de Engenharia de Transportes II.t. 
Aos meus pais, Carlos e Rozangela, e À minha irmã, Marcella, Amores da minha vida. 


\section{AGRADECIMENTOS}

A Deus, por me guiar, iluminar, proteger e abençoar em cada etapa desse trabalho.

Aos meus pais, Carlos Alberto e Rozangela, exemplos de dedicação e garra, por todo o apoio, instruções e constante presença, mesmo de longe. À minha irmã, Marcella, pelo apoio, preocupação, amor e companheirismo.

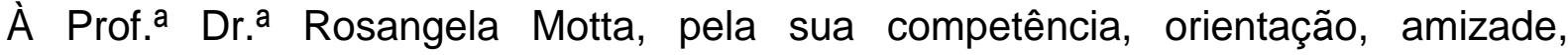
conhecimento, paciência, incentivo na área acadêmica, e por acreditar sempre no meu trabalho. Muito obrigado por tudo.

À Prof. ${ }^{\text {a }}$ Dr. a Liedi Bernucci, exemplo de excelência na área acadêmica e profissional, pela confiança, dúvidas e sugestões que contribuíram significativamente para que esta pesquisa fosse desenvolvida.

Ao pesquisador Dr. José João Pires, pelo companheirismo, ideias, incentivo, dúvidas e conselhos preciosos, que certamente me ajudaram a crescer pessoalmente e profissionalmente, e me manter firme na pesquisa, por mais difícil que ela seja.

Ao grande Prof. Dr. Edson Moura, excelente docente e pesquisador, sempre disposto a ajudar, quando eu mais precisava. Obrigado "Ed", por contagiar felicidade e ânimo no LTP.

À Prof. a Dr. ${ }^{a}$ Kamilla Vasconcellos, exemplo de liderança, dedicação e experiência, pela transmissão do conhecimento e pelos necessários momentos de descontração e risadas.

Ao professor Dr. Massao, por todo o conhecimento transmitido nas suas aulas e por toda a ajuda durante a pesquisa.

Ao professor Dr. Marinho, pelas dúvidas referentes aos solos não saturados, base deste trabalho. 
Aos queridos amigos do LTP Beer: Paulo, Lucas, João, Kazuo, Ingrid, Laura, Leidy, Fernanda, Zila, Márcia, luri, Mateus, Talita, Larissa, Deise, Camila, Rodrigo, Bruno e demais colegas do grupo. Obrigado pela ajuda na pesquisa, parceria, força e descontração. Com vocês o mestrado foi mais leve.

Aos amigos da Geolnfra: Andrei, Uilian, Luana, Adrian e Pedro. Muito obrigado pelo convívio, paciência, ajuda com planilhas e dúvidas relacionadas à geotecnia. Com todo o conhecimento transmitido e a competência de vocês, esta pesquisa se tornou mais fácil.

Ao mestre Robson Costa, pela ajuda, incentivo no meio ferroviário e discussões de resultados da pesquisa. Obrigado pela disponibilidade sempre que eu precisei.

À secretária Diomária, pelo carinho e pela organização e ajuda na preparação de todos os documentos importantes, cruciais nessa trajetória, e aos técnicos: Toninho, Erasmo, Higor e Vanderley, pela ajuda na realização dos ensaios em laboratório.

Aos professores, Drạ. Maria Eugênia, Dr. Faiçal e Dr. Renato, pelos ensinamentos transmitidos e dúvidas.

Ao Prof. Dr. Walter Canales, por todos os conhecimentos e experiência acadêmica transmitida da melhor forma, e por ter me colocado em contato com a pesquisa científica, acreditando sempre no meu potencial.

Ao Laboratório de Mecânica dos Solos (LMS) da EPUSP, pelas suas portas abertas sempre quando precisei realizar os ensaios necessários para esse trabalho.

À Vale S.A., pela concessão de bolsa de fomento à pesquisa e disponibilização dos sensores utilizados nesse trabalho.

À MRS Logística, por disponibilizar o trecho experimental para a realização das campanhas de medição em campo e a todos aqueles que contribuíram direta e indiretamente para que eu conseguisse desenvolver esta pesquisa. 
Não se pode ensinar tudo a alguém. Pode-se apenas, ajudá-lo a encontrar por si mesmo.

(Galileu Galilei) 


\section{RESUMO}

A subestrutura ferroviária é uma parte importante da via permanente, pois seu comportamento pode afetar significativamente o desempenho global da via, impactando em manutenção e custos. $O$ fato é que os materiais da subestrutura, como o subleito, estão no estado não-saturado na maior parte do tempo, e suas propriedades hidromecânicas dependem diretamente do grau de saturação e dos valores de sucção. Além disso, o estado não-saturado do solo é regido pelas ações atmosféricas e climáticas, o que torna fundamental a análise da influência de características ambientais e geotécnicas, tais como a precipitação, evaporação, tipo de solo e drenagem na resposta estrutural do subleito. Países de clima tropical/subtropical, como o Brasil, possuem elevada taxa de precipitação anual, e, por isso, merecem atenção especial quando se trata da interação via-clima. Mudanças da umidade ou sucção ou da taxa de infiltração no interior do subleito podem impactar significativamente no seu estado de tensões. O principal objetivo desta pesquisa foi avaliar a influência da variação da umidade e sucção no comportamento hidromecânico de um subleito ferroviário, localizado na região costeira do estado de São Paulo, considerando-se as características geotécnicas e climáticas locais. A interação via-clima foi investigada através de análises numéricas em elementos finitos (MEF) de infiltração saturada/não-saturada, aplicando-se parâmetros determinados em laboratório e monitoramento de campo. Para as simulações numéricas foi utilizado o software SEEP/W, enquanto no monitoramento de campo foram empregados sensores de matriz granular para medição do potencial matricial no solo. A caracterização mecânica do solo de subleito se baseou em resultados de módulo de resiliência obtidos por ensaios triaxiais cíclicos, em diferentes condições e ciclos de umidade e sucção. As simulações numéricas apresentaram importantes variações da sucção no solo em função das condições geotécnicas e climáticas, verificando-se a significância dos aspectos climáticos no comportamento hidráulico e mecânico do subleito da via férrea.

Palavras-chave: Ferrovias (infraestrutura), Solo não saturado, Influência climática, Umidade do solo, Infiltração superficial 


\begin{abstract}
The track substructure is an important part of a railway that requires attention when considering its whole global mechanical performance. Improving the long-term resistance to deformation behavior and therefore reducing maintenance problems during the operation of a track is always presented between engineers and researchers. The fact is that the substructure materials, such as the subgrade, are mostly in unsaturated state, and their hydro-mechanical properties are directly dependent on saturation degree and suction values. Besides, unsaturated state of the soil is controlled by atmospheric actions and climate conditions. Considering this, it is fundamental to analyze the influence of the environmental and geotechnical characteristics such as precipitation, evaporation, soil type, and drainage in the subgrade structural response. Countries with tropical/subtropical climate, such as Brazil, which have a high average annual precipitation rate, deserve special attention concerning climate-track interaction in railway performance. A little variation in the water content or infiltration rate into the subgrade may affects significantly their stress state. The main objective of this paper is to evaluate the influence of the water content and suction changes on mechanical behavior of a track substructure in a Brazilian coastal region, at São Paulo state, considering geotechnical characteristics and local climate. The climate-track interaction was evaluated through field monitoring and finite element numerical analysis with parameters obtained in the laboratory for all the materials involved. Numerical simulations were performed using SEEPW software and the field monitoring was realized through granular matrix sensors (GMS). Soil mechanical characterization was based on resilient modulus values determined through cyclic triaxial tests in different moisture/suction conditions. Numerical results showed an important variation of soil suction over time in function of geotechnical and climate data. In the simulated scenario, considering tropical local climate it was observed the importance of climate aspects in the hydraulic and mechanical behavior of the geotechnical components of the railway track.
\end{abstract}

Keywords: Railways (infrastructure), Unsaturated soil, Climate influence, Soil moisture, Surface seepage 


\section{SUMÁRIO}

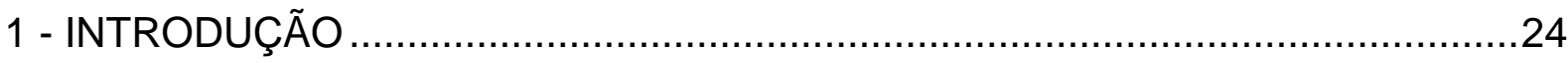

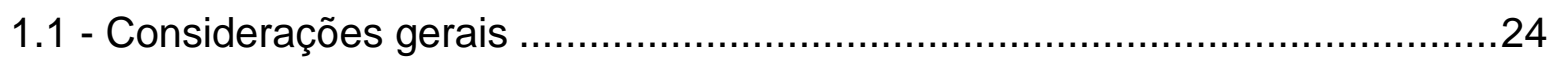

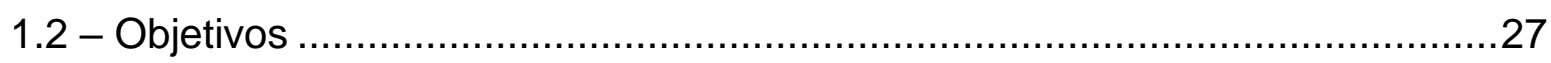

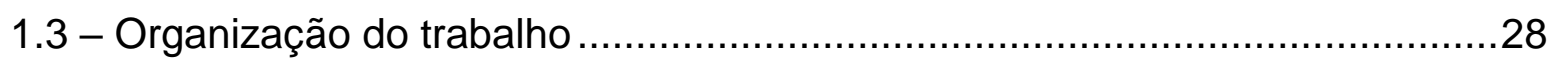

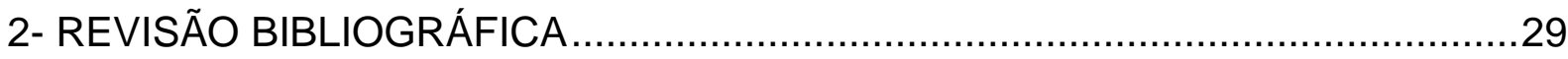

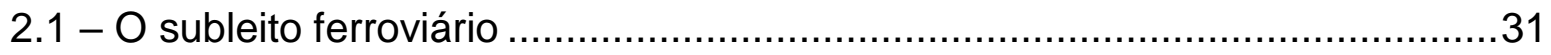

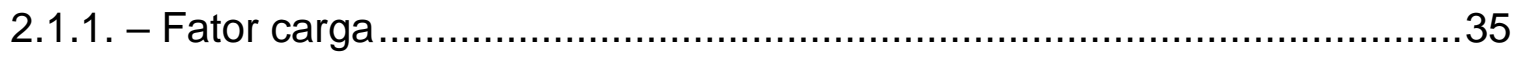

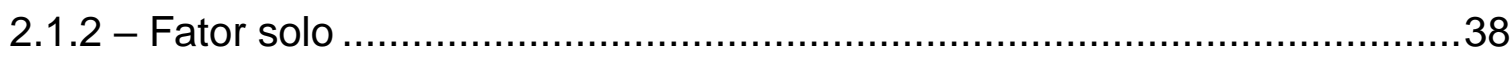

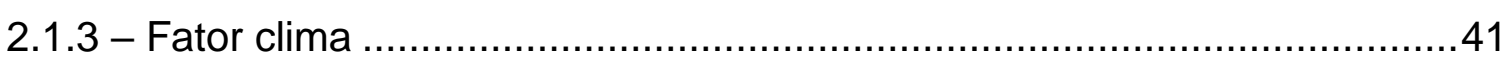

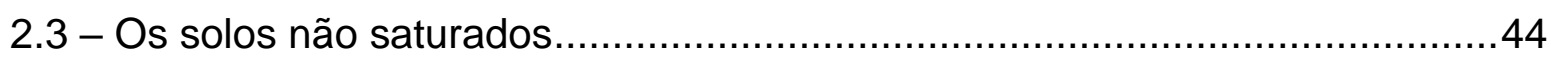

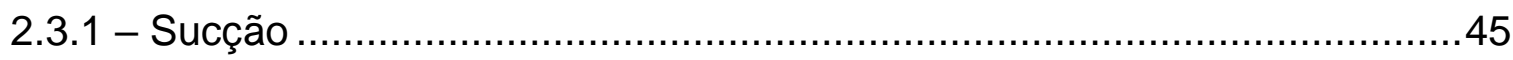

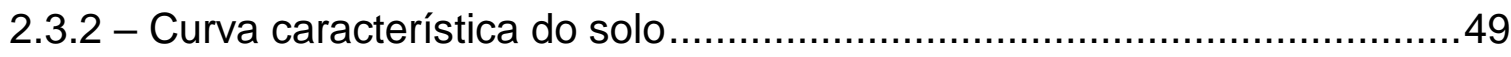

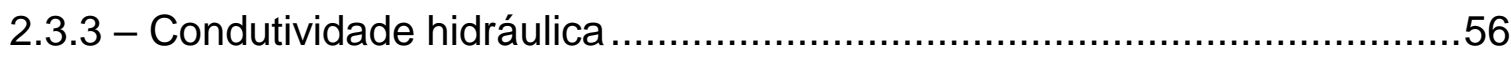

2.3.4 - Métodos de medida e controle da sucção.............................................57

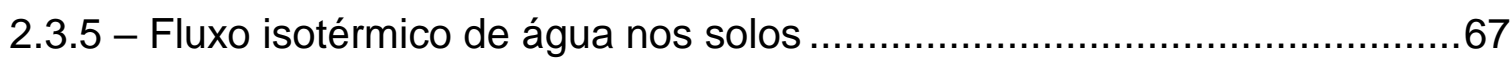

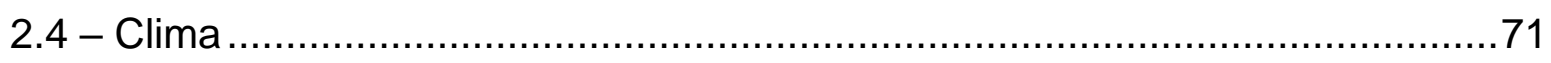

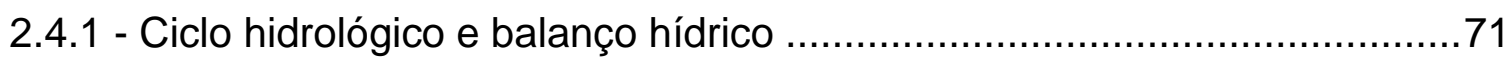

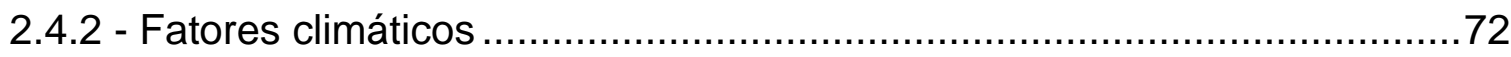

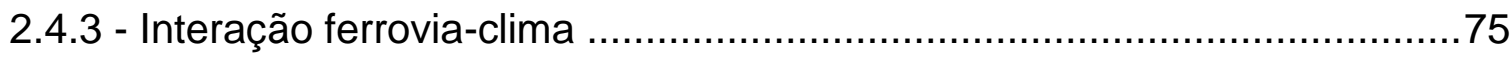

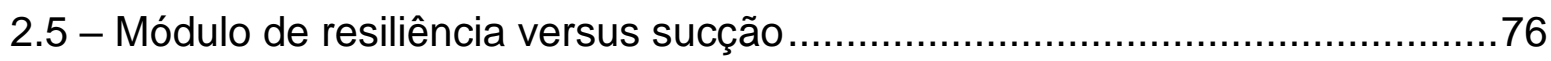

2.6 - Modelagem numérica de fluxo não saturado em meio poroso ........................79

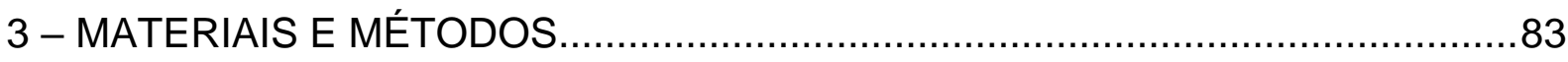

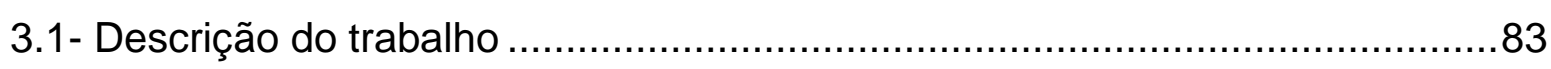

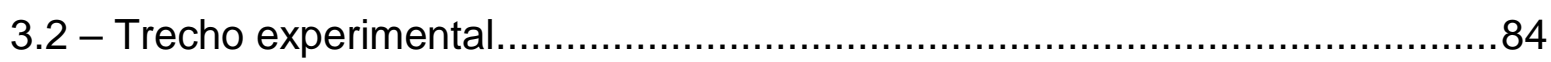

3.3 - Programa experimental em laboratório ................................................. 88

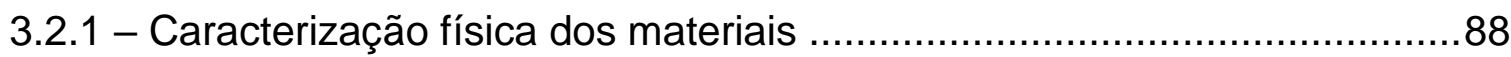

3.2.2 - Caracterização hidráulica dos materiais..............................................

3.2.3 - Caracterização mecânica do solo de subleito .......................................98

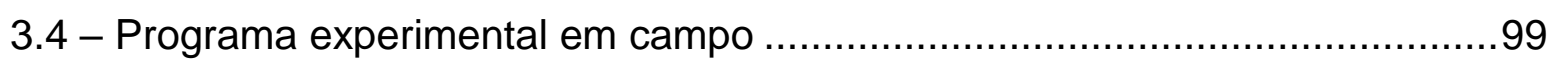

3.5 - Modelagem numérica de infiltração de água pluvial na via férrea................101

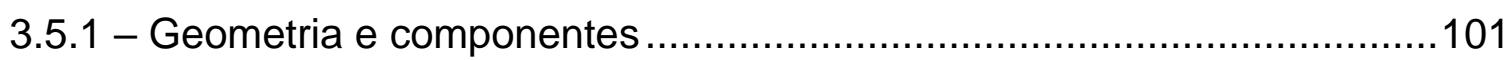




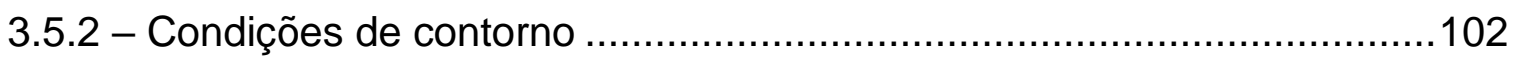

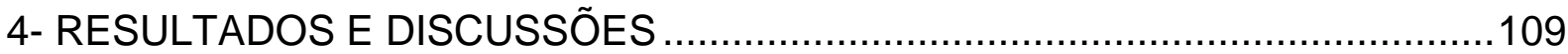

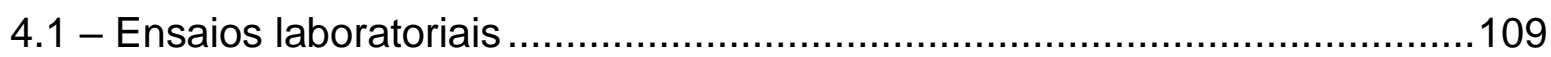

4.1.1 - Caracterização física dos materiais da via permanente .......................109

4.1.2 - Caracterização hidráulica dos materiais da via permanente .................115

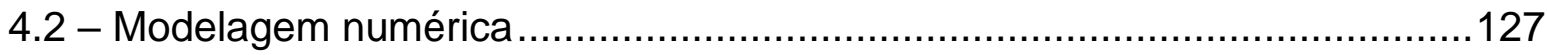

4.2.1 - Balanço hídrico do perfil estrutural da via permanente ….....................129

4.2.2 - Sucção/grau de saturação do subleito versus tempo............................131

4.2.3 - Estações do ano versus comportamento hidráulico do subleito.............132

4.2.4 - Umidade de equilíbrio do subleito ao longo de três anos......................146

4.2.5 - A influência da época de compactação e das características hidráulicas do subleito no seu comportamento hidráulico ...............................................147

4.2.6 - A influência da variação das condições hidráulicas e geométricas do sublastro no comportamento hidráulico do subleito .......................................150

4.2.7 - Nível freático versus comportamento hidráulico do subleito .................157

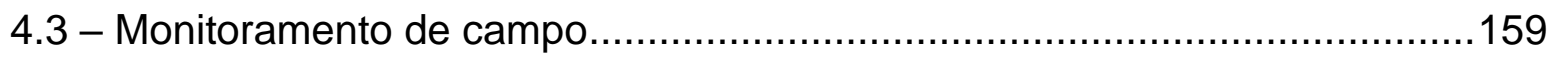

4.4 - Caracterização mecânica do subleito - Módulo de resiliência ......................164

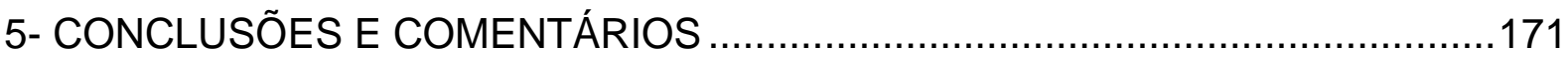

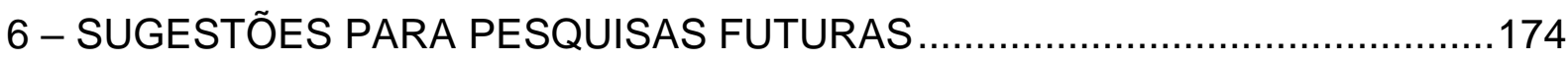

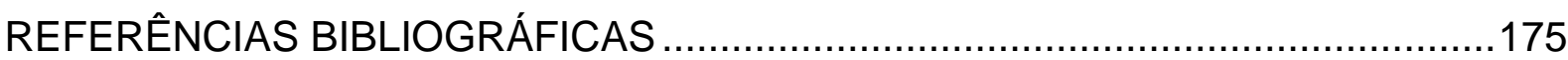




\section{LISTA DE FIGURAS}

Figura 1 - Evolução do transporte de carga nas malhas ferroviárias do Brasil de 2006 a 2016 (em bilhões de TKU).

Figura 2 - Produção de transporte ferroviário de cargas em milhões de toneladas útil (TU) por concessionária em 2016 .25

Figura 3 - Componentes da via permanente lastrada 29

Figura 4 - Presença de água em subleito ferroviário 31

Figura 5 - Ruptura por cisalhamento progressivo no subleito .32

Figura 6 - Deformação plástica excessiva no subleito: (a) seção transversal; e (b) seção longitudinal. .33

Figura 7 - Vazios do lastro preenchidos com lama devido ao bombeamento de finos

Figura 8 - Bombeamento de finos: (a) presença de água; (b) carga cíclica; e (c) prevenção 34

Figura 9 - Distribuição de tensões no subleito ferroviário .......................................37

Figura 10 - Elemento de um solo não saturado. 44

Figura 11 - A mecânica dos solos não saturados: (a) no mundo; (b) classificação .. 45

Figura 12 - Modelo físico do fenômeno da capilaridade .46

Figura 13 - Fenômeno da capilaridade por meniscos capilares .48

Figura 14 - Parâmetros de curva característica. .50

Figura 15 - Curvas características em função do tipo de solo .52

Figura 16 - Efeito da estrutura na sucção do solo. .53

Figura 17 - Efeito da histerese de um solo não saturado ..........................................53

Figura 18 - Sistema utilizado para o ensaio de placa de sucção..............................60

Figura 19 - Esquema da técnica da placa de pressão .............................................62

Figura 20 - Duas configurações do ensaio do papel filtro ......................................63

Figura 21 - Sensores de medição de potencial matricial: (a) GMS; (b) TEROS-21..65 Figura 22 - Calibração Watermark 200SS "Resistência elétrica do sensor versus sucção". .66

Figura 23 - Curva de retenção do disco poroso do sensor TEROS-21 .67

Figura 24 - Elemento de volume de solo ........................................................

Figura 25 - Principais componentes do ciclo hidrológico. .71 
Figura 26 - Precipitação média anual global

Figura 27 - Precipitação total (a), evaporação (b) e temperatura (c) médias mensais de 1981 a 2010 .74

Figura 28 - Esquematização da interação via-clima .75

Figura 29 - Influência do clima nos estados de tensões do solo de um subleito ferroviário .76

Figura 30 - Módulo de resiliência versus sucção do solo .77

Figura 31 - Módulo de resiliência versus sucção do solo .78

Figura 32 - Módulo de resiliência versus tensão desvio por processo de secagem e de secagem-umedecimento .78

Figura 33 - Variação do módulo de resiliência de solo rígido com a sucção e tensão desvio (para tensão de confinamento de $10 \mathrm{kPa}$ ) 79

Figura 34 - Exemplo do gráfico de balanço hídrico obtido no contorno ou superfície do modelo .82

Figura 35 - Esquema da metodologia do estudo .84

Figura 36 - Trecho experimental: (a) coordenadas geográficas; (b) compactação do subleito .84

Figura 37 - Configurações do trecho experimental em Piaçaguera/Raiz da Serra....85 Figura 38 - Média mensal de precipitação, evaporação, temperatura e fluxo efetivo na Baixada Santista de 1981 a 2010 .86

Figura 39 - Coleta de solo do subleito .87

Figura 40 - Ensaio de permeabilidade saturada do solo no Tri-Flex 2: (a) corpo de prova (CP), (b) posicionamento do $\mathrm{CP}$, (c) submissão do $\mathrm{CP}$ à pressão hidrostática; e (d) realização do ensaio. 91

Figura 41 - Método da placa de sucção .92

Figura 42 - Mini-CP's $(3,8$ × 2,0 cm) compactados estaticamente para a obtenção da SWCC .93

Figura 43 - Placa de pressão ou "panela" .93

Figura 44 - Determinação da curva característica a partir de sensores Watermark 200SS: (a) esquematização; (b) instalação.

Figura 45 - Determinação da curva característica do solo utilizando-se sensores Teros-21: (a) esquematização; (b) instalação .96 
Figura 46 - Método do papel filtro: (a) corpo de prova $(3,8 \times 2,0 \mathrm{~cm})$; (b) aplicação do papel filtro; (c) empacotamento do corpo de prova por 7 dias; (d) retirada do papel filtro para pesagem

Figura 47 - Módulo de resiliência: (a) destorroamento; (b) moldagem; (c)

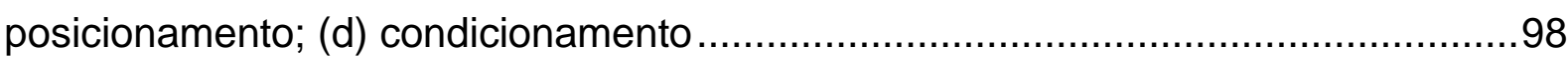

Figura 48 - Configuração transversal de instalação dos sensores Watermark..........99

Figura 49 - Análise de campo: (a) escavação manual; (b) local do sensor K.........100 Figura 50 - Geometria e malha das camadas da via permanente representadas pelo MEF 101

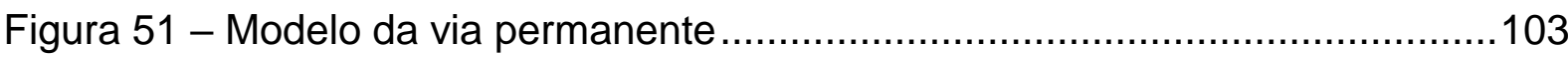

Figura 52 - Localização do nível freático e dos pontos analisados. 107

Figura 53 - Precipitação, evaporação potencial e temperatura diárias de 2016 a 2017 na Baixada Santista 107

Figura 54 - Umidade relativa do ar diária de 2016 a 2017 em Santos. 108

Figura 55 - Curva granulométrica 109

Figura 56 - Granulometria do sublastro granular de campo na faixa $C$ e de uma BGS na faixa $B$ 112

Figura 57 - Granulometria do lastro 114

Figura 58 - Curva característica do solo obtida pelo método 2 (umidade gravimétrica versus sucção) 116

Figura 59 - Curva característica do solo obtida pelo método 2 (umidade volumétrica versus sucção) 116

Figura 60 - Curva característica do solo obtida pelo método 3 (umidade gravimétrica versus sucção)

Figura 61 - Curva característica do solo obtida pelo método 3 (umidade volumétrica versus sucção)

Figura 62 - Curva característica do solo obtida pelo método 1 (umidade gravimétrica versus sucção)

Figura 63 - Curva característica do solo obtida pelo método 1 (umidade volumétrica versus sucção)

Figura 64 - Grau de saturação versus sucção obtida pelo método 1

Figura 65 - Índice de vazios versus sucção obtida pelo método 1 
Figura 66 - Curvas características: solo de campo e outras duas possíveis variações

Figura 67 - Curva de condutividade hidráulica do solo de subleito .......................122

Figura 68 - Curva característica do sublastro granular......................................123

Figura 69 - Curva de condutividade hidráulica do sublastro granular.....................124

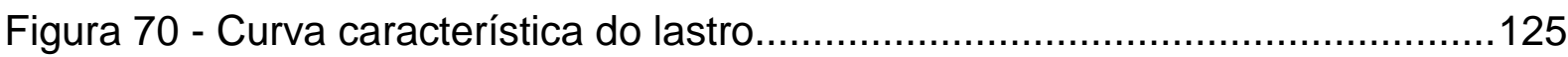

Figura 71 - Curva de condutividade hidráulica do lastro .....................................127

Figura 72 - Variação da sucção versus tempo desconsiderando-se a camada de lastro

Figura 73 - Variação da sucção versus tempo considerando-se a camada de lastro 128

Figura 74 - Balanço hídrico versus tempo para os anos de 2016 e 2017 ...............129

Figura 75 - Evaporação real e potencial.........................................................129

Figura 76 - Evaporação e infiltração efetivas ......................................................130

Figura 77 - Sucção versus as quatro estações do ano para 2016 e 2017 ..............131

Figura 78 - Grau de saturação versus as quatro estações do ano para 2016 e 2017

Figura 79 - Suç̧ão versus tempo (verão de 2016) ………………...................132

Figura 80 - Suç̧ão versus tempo (verão de 2017) …………….......................133

Figura 81 - Sucção versus profundidade (verão de 2016) …………...................134

Figura 82 - Suç̧ão versus profundidade (verão de 2017) …………....................134

Figura 83 - Sucção versus distância transversal (verão de 2016) ..........................135

Figura 84 - Sucção versus distância transversal (2017)......................................135

Figura 85 - Exemplo de drenagem em sublastro granular em condição não saturada 136

Figura 86 - Exemplo de saturação do sublastro granular .....................................136

Figura 87 - Sucção versus tempo (outono de 2016) ..........................................137

Figura 88 - Sucção versus tempo (outono de 2017) ...........................................137

Figura 89 - Sucção versus tempo (inverno de 2016)..........................................138

Figura 90 - Sucção versus tempo (inverno de 2017)........................................138

Figura 91 - Sucção versus profundidade (inverno de 2016) .................................139

Figura 92 - Sucção versus profundidade (inverno de 2017) .................................139

Figura 93 - Sucção versus distância transversal (inverno de 2016) ........................140 
Figura 94 - Exemplo do processo de secagem no perfil da via 140

Figura 95 - Fenômeno de umedecimento do subleito no inverno de 2016 após evento chuvoso

Figura 96 - Fenômeno de umedecimento do subleito no inverno de 2017 após evento chuvoso 142

Figura 97 - Chuva de inverno em 2016 142

Figura 98 - Chuva de inverno em 2017 143

Figura 99 - Sucção versus profundidade após evento chuvoso no inverno de 2016

Figura 100 - Sucção versus profundidade após evento chuvoso no inverno de 2017 144

Figura 101 - Exemplo do ciclo de umedecimento após período chuvoso em 2016.145

Figura 102 - Sucção versus tempo (primavera de 2016) 145

Figura 103 - Sucção versus tempo (primavera de 2017) 146

Figura 104 - Sucção versus tempo em três anos para os dados climáticos de 2016

Figura 105 - Compactação no inverno na umidade ótima 147

Figura 106 - Compactação no inverno com 6\% acima da umidade ótima 148

Figura 107 - Sucção versus tempo para diferentes tipos de solo 149

Figura 108 - Sucção versus tempo para sublastro com ksat $=3,66 \times 10^{-4}$ 150

Figura 109 - Sucção versus tempo para sublastro com $\mathrm{k}_{\text {sat }}=3,66 \times 10^{-6}$ 150

Figura 110 - Sucção versus tempo para sublastro com ksat $=3,66 \times 10^{-8}$. 151

Figura 111 - Sucção versus tempo para sublastro com diferentes sucções residuais 152

Figura 112 - Sucção versus tempo para diferentes condições de compactação do sublastro. 153

Figura 113 - Sucção versus tempo para diferentes extensões do sublastro granular de BGS 154

Figura 114 - Sucção versus tempo para diferentes espessuras de sublastro granular 155

Figura 115 - Escoamento superficial acumulado para diferentes condições de inclinação da via. 156

Figura 116 - Infiltração acumulada para diferentes condições de inclinação da via 156 
Figura 117 - Chuva acumulada para diferentes condições de inclinação da via .....156 Figura 118 - Sucção versus tempo para o ponto A para diferentes níveis freáticos 157 Figura 119 - Sucção versus tempo para o ponto B em diferentes cenários de níveis freáticos 158

Figura 120 - Sucção versus tempo para o ponto E em diferentes cenários de níveis freáticos 158

Figura 121 - Sucção versus tempo de campo em 2018 159

Figura 122 - Calibração dos valores obtidos em campo de umidade e sucção com a curva característica determinada através do método 2

Figura 123 - Sucção versus distância transversal em campo na superfície em 2018 162

Figura 124 - Análise da tensão de sucção do subleito aferidas em campo na superfície 163

Figura 125 - Sucção versus distância transversal em campo em profundidade no ano de 2018 163

Figura 126 - Análise da tensão de sucção do subleito aferidas em campo em profundidade 163

Figura 127 - Tensão desvio versus deformação para a umidade ótima ( $w=18,0 \%$ ) 165

Figura 128 - Tensão desvio versus deslocamento/deformação para a condição secagem-umedecimento $(\mathrm{w}=15 \%)$ 166

Figura 129 - Tensão desvio versus deslocamento/deformação para a condição de umedecimento-secagem ( $\mathrm{w}=15 \%)$ 166

Figura 130 - Módulo de resiliência versus tensão desvio para o CP1, CP2, CP3 e CP4 (escala logarítmica) 167

Figura 131 - Módulo de resiliência versus tensão desvio para o CP1, CP2, CP3 e CP4 (escala aritmética)

Figura 132 - Classificação da qualidade do subleito pela União Internacional de Ferrovias 168

Figura 133 - Valores de sucção obtidos após o ensaio de módulo pelos processos de umedecimento-secagem (UMED-SEC) e secagem-umedecimento (SEC-UMED) .170 


\section{LISTA DE TABELAS}

Tabela 1 - Técnicas para medição de sucção em solos 58

Tabela 2 - Tempo de equilíbrio para o método do papel filtro na determinação da sucção total .63

Tabela 3 - Resumo das propriedades físicas e classificação do solo 112

Tabela 4 - Resumo das propriedades físicas do sublastro granular em três condições 113

Tabela 5 - Análise granulométrica do lastro 114

Tabela 6 - Resultados dos índices físicos do lastro 115

Tabela 7 - Características de moldagem e parâmetros de ajuste da curva característica (método 2) 116

Tabela 8 - Características de moldagem e parâmetros de ajuste da curva característica (método 3) 117

Tabela 9 - Características de moldagem dos corpos de prova (CP) e parâmetros de ajuste das curvas 120

Tabela 10 - Permeabilidade saturada do subleito nas direções $\mathrm{x}$ e $\mathrm{y}$ 121

Tabela 11 - Permeabilidade do sublastro (BGS). 124

Tabela 12 - Permeabilidade do lastro 125

Tabela 13 - Agregados de lastro de acordo com dados de laboratório e local de extração nos EUA 126

Tabela 14 - Dados da curva característica dos materiais 127

Tabela 15 - Dados de permeabilidade dos materiais

Tabela 16 - Precipitação diária acumulada após evaporação máxima 143 


\section{LISTA DE ABREVIATURAS E SIGLAS}

PND Programa Nacional de Desestatização

CNT Confederação Nacional de Transportes

TKU Tonelada Quilômetro Útil

ANTT Agência Nacional de Transportes Terrestres

PIB Produto Interno Bruto

$\mathrm{HH} \quad$ Heavy Haul

IPCC Intergovernmental Panel on Climate Change

BGS Brita Graduada Simples

AREMA American Railway Engineering and Maintenance-of-Way

Association

SUSC

Sistema Unificado de Classificação de Solos

TRB

Transportation Research Board

MCT

Miniatura Compactada Tropical

CBR

California Bearing Ratio

GRAFT

Geopavement and Railway Accelerated Fatigue Testing

SWCC

Soil Water Characteristic Curve

GMS

Granular Matrix Sensors

INMET

Instituto Nacional de Meteorologia

$\mathrm{SP}$

São Paulo

MEF

Método dos Elementos Finitos

LTP

Laboratório de Tecnologia de Pavimentação

LMS

Laboratório de Mecânica dos Solos

USP

Universidade de São Paulo

ABNT

Associação Brasileira de Normas Técnicas

DNER

Departamento Nacional de Estradas de Rodagem

ASTM

American Society for Testing Materials

DERSA

Departamento de Estradas de Rodagem do Estado de São Paulo

HRB Highway Research Board

AASHTO

American Association of State Highway and Transportation Officials

LCT Laboratório de Caracterização Tecnológica

ETCR

Ensaios triaxiais de cargas repetidas 
Departamento Nacional de Infraestrutura de Transportes

LL Limite de liquidez do solo

LP Limite de plasticidade do solo

PT

Potential transpiration

PE

Potential evaporation

PET

Potential evapotranspiration

SCF

Soil cover fraction

INPE

Instituto Nacional de Pesquisas Espaciais

IG

Índice de Grupo (da Classificação HRB de Solos)

ICDD

International Centre for Diffraction Data

ICSD

Inorganic Crystal Structure Database

$\mathrm{CNU}$

Coeficiente de não uniformidade

VEA

Valor de sucção de entrada de ar no solo

METAR

Meteorological Aerodrome Report

LVDT

Linear Variable Displacement Transducer

UIC

Union Internationale des Chemins de Fer 


\section{LISTA DOS PRINCIPAIS SÍMBOLOS}

\begin{tabular}{|c|c|}
\hline$\sigma, \sigma_{d}$ & Tensões total e desvio \\
\hline$u_{a}, u_{w}$ & Pressão do ar e da água \\
\hline$\psi_{t}, \psi_{m}, \psi_{o}$ & Sucção total, matricial e osmótica \\
\hline$h_{c}$ & Altura da coluna d'água \\
\hline$T_{S}$ & Tensão superficial da água \\
\hline$g$ & Aceleração da gravidade \\
\hline$R_{S}$ & Raio de curvatura do menisco \\
\hline$\psi_{m}$ & Sucção matricial \\
\hline$T_{S}$ & Tensão superficial da água \\
\hline$\rho_{w}$ & Massa específica da água \\
\hline$R_{1}$ & Raio de curvatura do menisco menor \\
\hline$R_{2}$ & Raio de curvatura do menisco maior \\
\hline$R$ & Constante universal dos gases \\
\hline$T$ & Temperatura absoluta \\
\hline$v_{w 0}$ & Massa molecular do vapor de água dos poros \\
\hline$u_{v}$ & Pressão parcial de vapor de água nos poros \\
\hline$u_{v 0}$ & Pressão de saturação do vapor de água nos poros \\
\hline$S$ & Grau de saturação \\
\hline$e$ & Índice de vazios \\
\hline$\theta$ & Umidade volumétrica \\
\hline$w$ & Umidade gravimétrica \\
\hline$\gamma_{d}$ & Massa específica aparente seca \\
\hline$\theta_{r}$ & Umidade volumétrica residual \\
\hline$\theta_{s}$ & Umidade volumétrica saturada \\
\hline$\alpha$ & Sucção correspondente à entrada de ar \\
\hline$n, m$ & Constantes empíricas da função proposta por Van Genuchten (1980) \\
\hline$S_{c}$ & Componente capilar, a qual depende exclusivamente dos diâmetros \\
\hline \multicolumn{2}{|c|}{ dos poros e da distribuição dos poros } \\
\hline$S_{a}$ & Componente de adesão \\
\hline$\eta$ & Porosidade \\
\hline$\Theta$ & Teor de umidade volumétrica normalizado \\
\hline
\end{tabular}




$\begin{array}{ll}k(\Theta) & \text { Condutividade hidráulica para um determinado } \Theta \\ k_{s a t} & \text { Condutividade hidráulica saturada } \\ \Theta_{s} & \text { Umidade volumétrica normalizada saturada } \\ g & \text { Aceleração da gravidade } \\ z_{b} & \text { Altura da amostra de solo } \\ z_{a} & \text { Altura do reservatório de água } \\ P & \text { Sucção matricial aferida pelo sensor Watermark } \\ R & \text { Resistência elétrica ou facilidade de circular corrente elétrica pelo } \\ \text { meio poroso } & \\ h & \text { Carga hidráulica total } \\ z & \text { Cota altimétrica de um ponto } \\ \mu & \text { Pressão da água nos poros (piezométrica) em um ponto qualquer } \\ V & \text { Velocidade de percolação intersticial em um ponto } \\ \mathrm{v}_{w} & \text { Velocidade da água } \\ q & \text { Densidade de fluxo; } \\ A & \text { Área da secção transversal por onde ocorre o fluxo } \\ k_{w} & \text { Coeficiente de permeabilidade para a fase da água } \\ \frac{\varphi H}{\varphi z} & \text { Gradiente hidráulico na direção vertical } \\ k(\theta) & \text { Condutividade hidráulica em função do grau de saturação (solos não } \\ \text { saturados) } & \\ \frac{\varphi \theta}{\varphi t} & \text { Frecipitação } \\ q_{x} & \text { Teor de umidade volumétrica por unidade de tempo } \\ q_{y} & \text { Fluxo na direção x } \\ q_{z} & \text { Fluxo na direção y } \\ k_{x} \text { e } k_{y} & \text { Fluxo na direção z } \\ m_{w} & \text { Coeficiente de variação volumétrica } \\ t & \\ I & \text { Fluxos positivos (entrada de água) } \\ O & \end{array}$


$\begin{array}{ll}R_{S r} & \text { Descarga fluvial } \\ R_{g} & \text { Descarga subterrânea } \\ \Delta S & \text { Água infiltrada no solo } \\ \{Q\} & \text { Vetor da quantidade de fluxo nos nós (ações) } \\ {[K]} & \text { Matriz de condutividade hidráulica, determinada pela curva }\end{array}$ característica (matriz de coeficientes relacionada às propriedades de geometria e materiais)

$\{H\}$

Vetor da carga hidráulica total nos nós (variáveis de campo ou desconhecidas)

$k_{\text {sat }} \quad$ Condutividade hidráulica saturada

$D_{15} \quad$ Diâmetro equivalente à porcentagem de $15 \%$ passante

$D_{85} \quad$ Diâmetro equivalente à porcentagem de $85 \%$ passante

$D_{50} \quad$ Diâmetro equivalente à porcentagem de $50 \%$ passante

Gs Densidade real dos grãos

$\gamma \quad$ Massa específica natural do solo

$\varepsilon \quad$ Erro

$\theta_{i} \quad$ Teor de umidade volumétrico previsto

$\theta^{\wedge}{ }_{i} \quad$ Teor de umidade volumétrico medido

$N \quad$ Número total de pontos experimentais

$q_{I} \quad$ Infiltração

$q_{R} \quad$ Escoamento superficial ou runoff

$q_{E}, q_{P}, q_{M} \quad$ Evaporação, precipitação e degelo.

$\alpha_{e} \quad$ Ângulo de inclinação do aterro

$q_{I}^{\text {sim }} \quad$ Fluxo de infiltração simulada

$q_{P E} \quad$ Evaporação potencial

$q_{P E T} \quad$ Evapotranspiração potencial

$\mathrm{q}_{P T} \quad$ Transpiração potencial

SCF Fração de cobertura vegetal do solo

$q_{A E} \quad$ Evaporação real

$W_{v} \quad$ Massa molecular da água

$h_{a} \quad$ Umidade relativa do ar

y Elevação 


\section{1 - INTRODUÇÃO}

\section{1 - Considerações gerais}

A retomada de participação do setor privado no modal ferroviário através do Programa Nacional de Desestatização (PND) pelo Governo Federal em 1992, contribuiu para o aumento do investimento nas malhas federais brasileiras. Além disso, com o intuito de impulsionar a sua produção, as concessionárias de ferrovias investiram na gerência e manutenção da malha concedida. Em decorrência disso, houve em um curto espaço de tempo um aumento da produtividade (CNT, 2015). A Figura 1 mostra a evolução do transporte de carga no sistema ferroviário brasileiro de 2006 a 2016 em bilhões de Tonelada Quilômetro Útil (TKU).

Figura 1 - Evolução do transporte de carga nas malhas ferroviárias do Brasil de 2006 a 2016 (em bilhões de TKU)

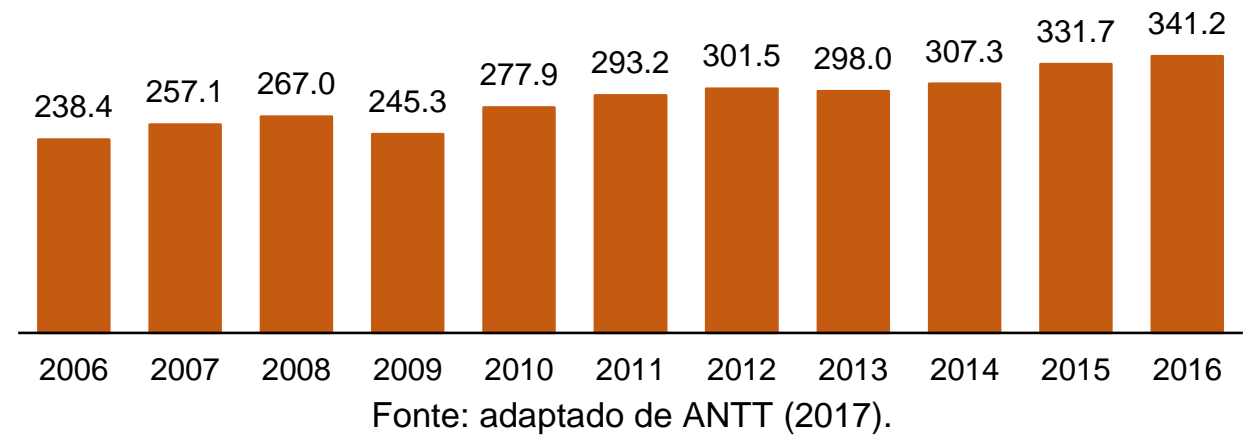

Baseando-se na Figura 1, é possível observar um aumento de $43,1 \%$ no transporte de carga em apenas 10 anos. De acordo com a CNT (2015), isso apresenta o grande potencial do transporte ferroviário de cargas no Brasil que, devido às suas características físicas e econômicas, evidencia a perspectiva de desenvolvimento, a partir de projetos de construção, revitalização e expansão provenientes da parceria público-privado.

A Figura 2 apresenta o transporte ferroviário de cargas por operadora no Brasil em 2016. Ressalta-se que, dentre as 32 vias férreas operantes no Brasil, a malha operada pela MRS Logística (onde está localizado o trecho experimental avaliado nesta pesquisa) está entre as maiores em volume de carga transportado no país. 
Figura 2 - Produção de transporte ferroviário de cargas em milhões de toneladas útil (TU) por concessionária em 2016

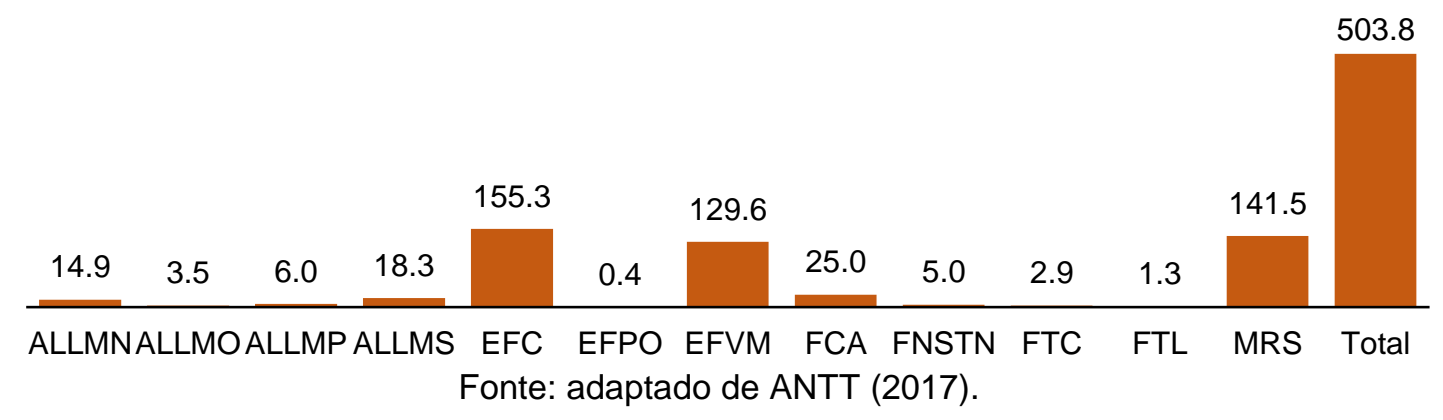

A MRS detém cerca de $20 \%$ da frota ferroviária nacional, compreendendo mais de 18 mil vagões e quase 800 locomotivas. A empresa compreende $1643 \mathrm{~km}$ de ferrovias nos estados de Minas Gerais, Rio de Janeiro e São Paulo, região responsável por aproximadamente metade do Produto Interno Bruto (PIB) brasileiro (https://www.mrs.com.br/empresa, acesso em 14/04/2018).

Segundo a ANTT (2017), a MRS detém cerca de 31,1\% do transporte do minério de ferro em condição heavy haul $(H H)$, considerada a principal comoditie transportada no país $(78,9 \%)$, e apresentou aumento do volume transportado de aproximadamente $40 \%$ nos últimos 10 anos.

A constante mudança das condições operacionais do cenário $H H$, como o aumento da carga por eixo transportada, passa a solicitar a via permanente cada vez mais intensamente, ocasionando a degradação do subleito e, consequentemente, dos componentes da superestrutura, podendo comprometer a geometria da via e elevar os custos com manutenções.

Isso acaba exigindo um comportamento estrutural e capacidade de carga adequados do subleito, a fim de não comprometer o tráfego com paralisações. LópezPita et al. (2007) ressaltam que quando o subleito possui propriedades mecânicas inadequadas, passa a contribuir com uma grande parcela da degradação total da geometria. Li e Selig (1995) e Hasnayn et al. (2017) comentam que a tentativa de correção da perda de geometria da via diante de problemas oriundos do subleito, ao invés da substituição ou melhoramento do solo e/ou instalação e manutenção de dispositivos de drenagem em locais críticos, se faz pelo processo de socaria, considerado altamente dispendioso e de baixa eficiência a longo prazo. 
Li (1994) verificou através de modelos numéricos que o fator que mais influência no módulo de via é o módulo de elasticidade do subleito. Por exemplo, vias onde o lastro passa a apresentar rigidez elevada em decorrência da cimentação de finos oriundos da colmatação e/ou contaminação, podem manter o seu valor de módulo à medida que o subleito se torne mais resiliente ou elástico. Isso acaba reduzindo o possível aumento do desgaste dos componentes da superestrutura, considerados mais caros.

Um dos principais e cruciais fatores que ocasionam problemas no subleito ferroviário é o clima, pois aliado às elevadas cargas por eixo de ferrovias $\mathrm{HH}$ passam a influenciar diretamente a condição de saturação do solo, induzindo à variação da sua capacidade de carga (LI e SELIG, 1995).

Dentro do contexto climático, deve-se ainda considerar que aumentos da temperatura do ar são esperados em nível global e que dentre as suas principais consequências estão as alterações no ciclo hidrológico, mudanças bruscas na frequência e intensidade de eventos extremos, como secas e/ou enchentes podem vir a ocorrer nos próximos anos (IPCC, 2013).

O Brasil, compreendendo os climas tropical/subtropical, apresenta elevadas taxas de precipitação no verão e taxas consideráveis de evapotranspiração durante o inverno. Esses eventos ocasionam uma dinâmica ou variação do fluxo da água nos poros do solo compactado, a qual é variável em função do tempo, pois depende diretamente das condições climáticas e do próprio estado de saturação do solo, que pode estar saturado ou não saturado (abaixo ou acima do lençol freático, respectivamente) (FREDLUND e RAHARDJO, 1993).

Rahardjo et al. (2011) e Han et al. (2015) reforçam que o aumento do grau de saturação (S) de um solo compactado, em função da ocorrência de eventos climáticos, é um fator significativo na degradação das suas propriedades de resistência, tais como a rigidez e módulo de resiliência. Isso ocorre devido à diminuição da sucção (tensão negativa de tração na água típica de solos não saturados, resultante da diferença da pressão entre o ar e a água) em períodos de chuva intensa e duradoura, sendo considerada a causa de inúmeras rupturas em aterros compactados (FREDLUND e RAHARDJO, 1993). Portanto, é determinante a aplicação dos princípios da mecânica 
dos solos não saturados, em termos de fluxo, tensões e deformações, considerandose a sucção como o fator fundamental no estado de tensões do subleito.

Yang et al. (2008) comentam que, em decorrência disso, tem-se aumentado consideravelmente a aplicação da mecânica dos solos não saturados no estudo do comportamento hidromecânico de subleito ferroviário nos últimos anos. Porém, tal abordagem é realizada em países onde o clima, a geologia, pedologia e as configurações operacionais das ferrovias são diferentes do cenário brasileiro, sendo necessária, portanto, sua exploração nacionalmente.

Tal conhecimento se torna relevante para fornecer subsídios em critérios de dimensionamento de perfis de subleito, no que tange à seleção e/ou substituição de materiais em vias novas e antigas, em procedimentos de construção e/ou manutenção. Assim, diante de ações climáticas extremas do clima tropical, pode-se proporcionar um melhor desempenho à via permanente no que tange a níveis desejáveis de segurança, velocidade, eficiência, transporte de carga, manutenções reduzidas e aumento da vida útil dos seus componentes.

Baseando-se no exposto, este trabalho busca avaliar a influência do clima e das condições geotécnicas nas propriedades hidráulicas e mecânicas do material do subleito de um trecho ferroviário experimental, considerando-se as ações climáticas.

\section{2 - Objetivos}

Essa dissertação tem como objetivo principal contribuir para um maior entendimento do comportamento hidromecânico de um subleito ferroviário exposto às variações climáticas, ou seja, em condições não saturadas. Para isso, foram feitas análises de dados provenientes de:

- Monitoramento da variação de umidade e sucção de um subleito ferroviário através de instrumentação de trecho experimental em campo;

- Caracterização física e hidráulica do material de solo do subleito da via permanente; 
- Modelagem numérica de infiltração em perfil estrutural da via permanente, baseando-se nas propriedades físicas e hidráulicas dos seus materiais constituintes obtidos em laboratório, e em dados reais de clima;

- Caracterização mecânica em laboratório do solo de subleito em condições não saturadas.

\section{3 - Organização do trabalho}

Este trabalho de pesquisa foi dividido em 6 capítulos:

- O primeiro apresenta uma breve introdução a respeito do tema proposto, assim como a sua justificativa;

- O segundo consiste em uma revisão bibliográfica sobre o comportamento do subleito ferroviário, aplicando-se os fundamentos dos solos não saturados com a influência do clima, assim como a variação do módulo de resiliência em função da umidade;

- O terceiro capítulo descreve o local do trecho ferroviário experimental estudado neste trabalho, assim como a metodologia adotada em laboratório e em campo para a realização desse estudo. Ressaltam-se os métodos e procedimentos utilizados para a determinação da relação entre o teor de umidade e a sucção do solo de subleito e uma breve descrição do software SEEP/W e suas características operacionais;

- O quarto capítulo apresenta as análises e os resultados dos testes experimentais em laboratório, tais como: caracterização física e hidráulica dos materiais da via e o comportamento resiliente em diferentes condições de umidade, obtendo-se a relação entre o módulo de resiliência e a sucção. Além disso, apresenta-se a variação da sucção ao longo do ano, através dos dados provenientes do modelo numérico e do monitoramento de campo;

- O quinto apresenta as conclusões dos resultados deste trabalho;

- O sexto finaliza com sugestões para pesquisas futuras relacionadas a interação viaclima. 


\section{2- REVISÃO BIBLIOGRÁFICA}

A via permanente lastrada ou convencional, responsável por guiar os trens com segurança e proporcionar rolamento suave no contato roda-trilho, funciona como uma estrutura elástica multicamadas, projetada para resistir aos danos ocasionados pelas cargas do material rodante e pelos fatores ambientais (MUNIZ DA SILVA, 2002). De acordo com Selig e Waters (1994), ela é composta por duas partes com diferentes componentes: a superestrutura e subestrutura. No âmbito desta pesquisa, a superestrutura irá compreender os trilhos, apoios, fixações e dormentes, e a subestrutura compreenderá as camadas de lastro, sublastro e o subleito (estes dois últimos são foco deste trabalho), como mostra a Figura 3.

Figura 3 - Componentes da via permanente lastrada

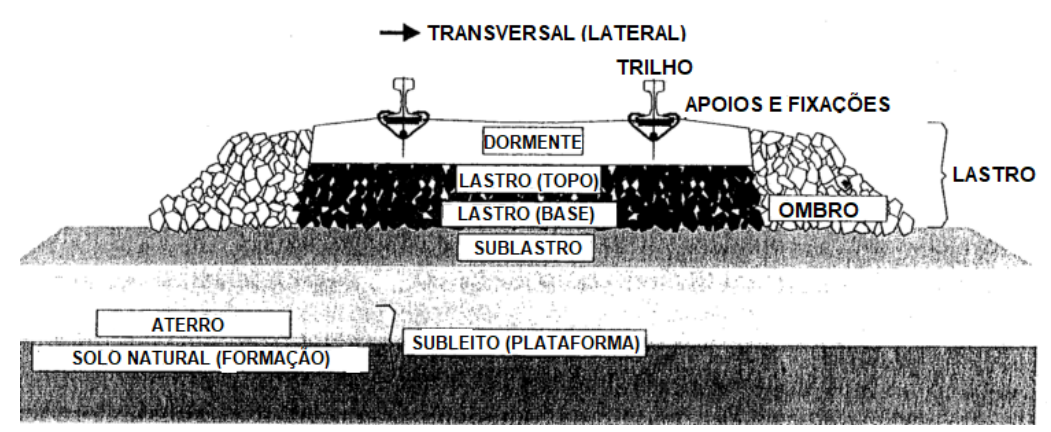

Fonte: adaptado de Selig e Waters (1994).

O sublastro pode ser composto de material granular (BGS), solos locais estabilizados quimicamente (cimento, asfalto, cal, etc.), misturas asfálticas e geossintéticos. Segundo Selig e Waters (1994), esta camadade deve atender às seguintes funções: (i) dissipar as tensões oriundas do tráfego a valores menores do que a capacidade de carga do subleito; (ii) evitar o contato do subleito com o lastro evitando o bombeamento de finos; e (iii) drenar a água proveniente da chuva que infiltra no lastro, e transportá-la diretamente para dispositivos de drenagem laterais da via, a fim de que não comprometa o comportamento do subleito.

O subleito pode ser composto por solo natural ou transportado. É conhecido também por "plataforma" ou fundação, na qual a via é construída, apresentando como função proporcionar apoio adequado para as camadas sobrejacentes. De acordo com Selig e Waters (1994), o fato de que as tensões induzidas pelo tráfego alcançam 
profundidades de $5 \mathrm{~m}$, aproximadamente, a partir da base dos dormentes, evidencia a importância do subleito quanto a sua influência no desempenho e na manutenção da ferrovia.

Embora as cargas oriundas do tráfego possam atingir a profundidade anteriormente mencionada, é comum haver uma preocupação especial com as propriedades do subleito em torno de 1 a 2 m abaixo da base do dormente (FORTUNATO, 2005). Tal afirmação pode estar atribuída à existência de maior interação entre o subleito e os efeitos climáticos nessas profundidades, que pode ocasionar maiores oscilações das condições de saturação do solo.

Como a via permanente é considerada um sistema estrutural em camadas ou pavimento ferroviário (MUNIZ DA SILVA, 2002), deformações excessivas no subleito podem ocasionar recalques diferenciais nas camadas superiores, comprometendo a geometria da via férrea. Desse modo, é crucial que elevadas quantidades de água provenientes das precipitações sejam adequadamente removidas de tal forma que a integridade da via seja mantida.

Subleitos ferroviários compostos por solos finos, tais como os solos argilosos e siltosos, são mais propícios à perda de capacidade de suporte devido sua sensibilidade particular à variação da umidade (GHATAORA e RUSHTON, 2012). Por isso que, subleitos rígidos também podem vir a sofrer amolecimento e degradação em decorrência dos fenômenos climáticos (GATHAORA et al., 2006).

Para que a via desempenhe um bom comportamento, ou seja, possibilite o transporte do material rodante de forma contínua, com estabilidade e eficiência, sem perda de geometria e recalques diferenciais, é necessário que cada elemento da mesma cumpra adequadamente suas respectivas funções.

Assim, todo o sistema pode proporcionar resiliência e, ao mesmo tempo, rigidez adequadas, limitando o desgaste e as deformações permanentes diante das condições operacionais impostas (FORTUNATO, 2005; HAY, 1982). 


\section{1 - 0 subleito ferroviário}

A carga transmitida no contato roda-trilho sempre alcança o subleito (ou plataforma ferroviária). Dentre suas funções principais, podem ser destacadas (HAY, 1982; PROFILLIDIS, 2006; INDRARATNA et al., 2011): (i) apresentar rigidez e capacidade de carga adequadas para permitir passagem dos trens de forma estável e segura em velocidades especificadas; (ii) evitar deformações plásticas excessivas; (iii) facilitar a drenagem garantindo menores custos com manutenções na via a longo prazo ao proporcionar uma plataforma suave e nivelada para a camada de lastro.

De acordo com Selig e Waters (1994), para que o subleito possa desempenhar suas funções é necessário que o mesmo não apresente os seguintes problemas estruturais: (i) ruptura por cisalhamento e adensamento em decorrência do seu peso próprio e sobrecargas; (ii) deformações plásticas excessivas diante das cargas repetidas geradas pela passagem dos trens aliadas aos ciclos de secagem e umedecimento decorrentes dos fenômenos climáticos; e (iii) ruptura por cisalhamento progressivo em decorrência das cargas dinâmicas e da presença de água na estrutura.

A presença de água no subleito pode ocorrer em decorrência de chuvas intensas aliadas à sistemas de drenagem deficientes. Segundo Rushton e Ghataora (2014), problemas de drenagem proporcionam o acúmulo de uma grande quantidade de água na parte superior do subleito ferroviário, ocasionando seu amolecimento e possível ruptura, os quais estão aliados à perda da capacidade de suporte (Figura 4).

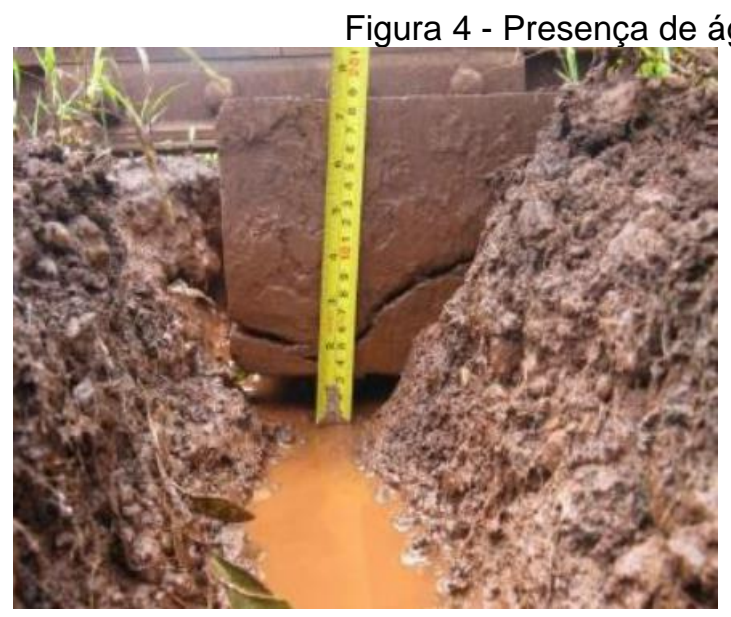

(a)

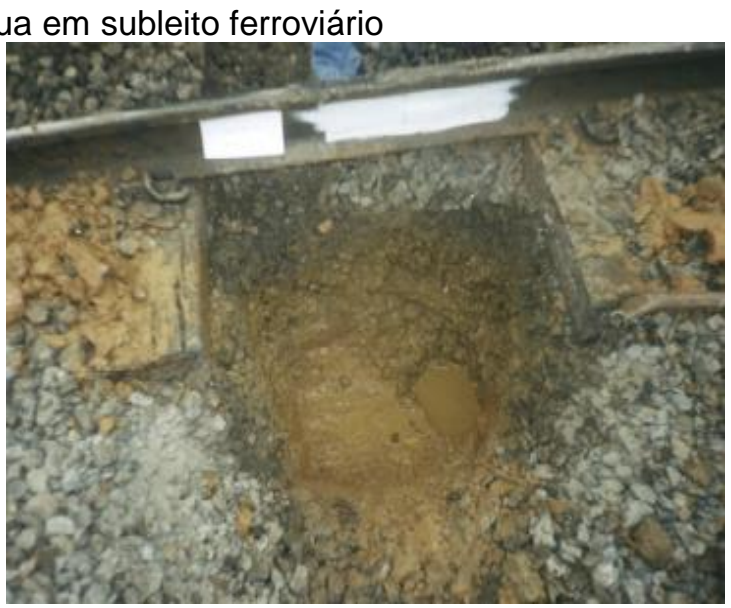

(b)

Fonte: (a) Cordeiro et al. (2015); (b) Paiva et al. (2015). 
Usman et al. (2015) desenvolveram diagramas de análises e relações existentes entre a qualidade dos sistemas de drenagem da via permanente (capacidade de extrair-se a água da subestrutura) e os tipos de ruptura ocasionadas no subleito. Dentre eles, podem ser destacados como os tipos mais comumente relatados na literatura e na prática (LI e SELIG, 1995, 1998): (i) ruptura por cisalhamento progressivo; (ii) deformação plástica excessiva e; (iii) bombeamento de finos.

A ruptura por cisalhamento progressivo é originada na superfície do subleito quando o seu plano de ruptura é cisalhado, em decorrência das cargas cíclicas elevadas aliadas à presença de água, e depende do tipo e da umidade do solo (Figura 5).

Figura 5 - Ruptura por cisalhamento progressivo no subleito

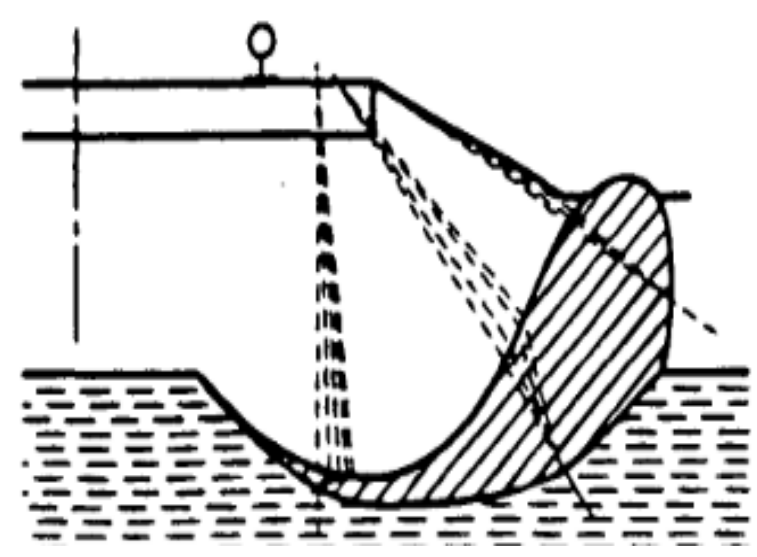

(a)

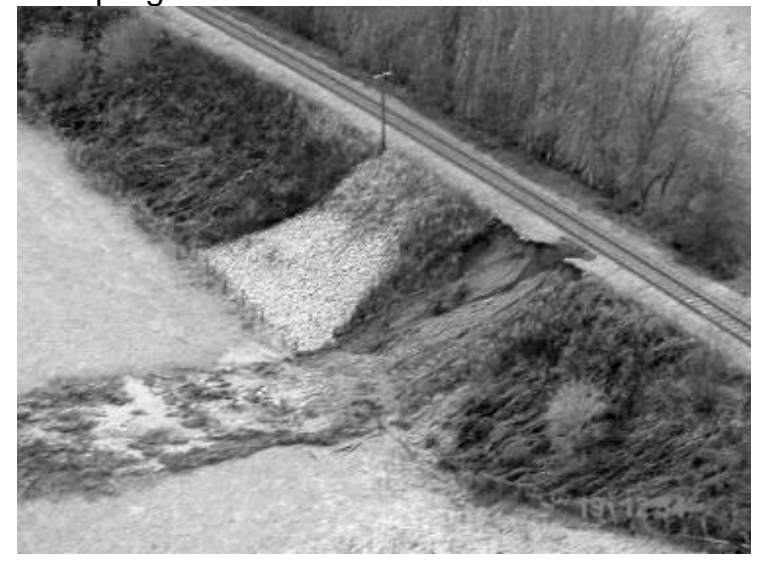

(b)

Fonte: adaptado de (a) Li (1994) e Li e Selig (1995, 1998); e (b) Glendinning et al. (2009).

De acordo com Li e Selig $(1995,1998)$, esse tipo de ruptura é caracterizado quando o solo entra em colapso por cisalhamento, de tal forma que um plano de baixa resistência é propagado gradualmente, empurrando a massa de solo adjacente para cima.

Muniz da Silva (2002) comenta que, apesar de importante, a ruptura é rara em pavimentos, ocorrendo geralmente as deformações permanentes, as quais são tradicionalmente consideradas na manutenção das vias permanentes ferroviárias, pois podem provocar a perda de geometria. Isso ocorre à medida que surgem deformações plásticas excessivas ou recalques diferenciais na superfície do subleito que, de forma geral, resulta em bolsões de lastro (Figura 6). 
Figura 6 - Deformação plástica excessiva no subleito: (a) seção transversal; e (b) seção longitudinal

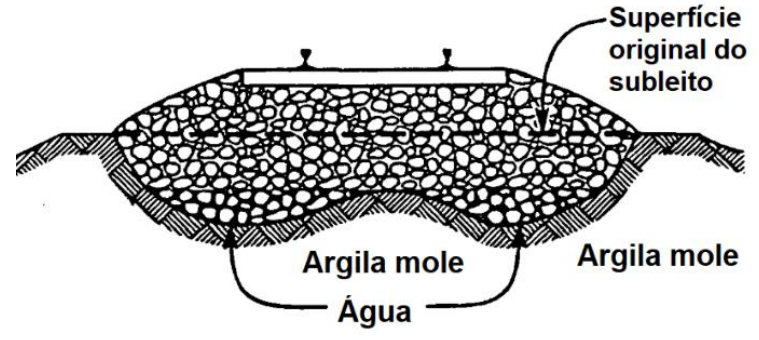

(a)

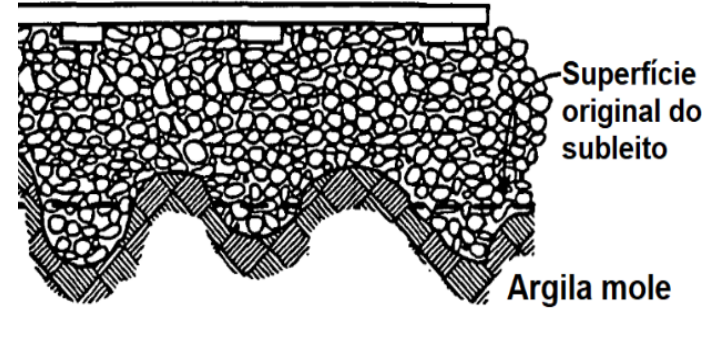

(b)

Fonte: adaptado de Usman et al. 2015.

Esses bolsões expressivos no subleito são oriundos de deformações plásticas por cisalhamento decorrentes das cargas cíclicas provenientes do tráfego e da presença de água no sistema, combinadas ao longo do tempo (LI e SELIG, 1995, 1998; USMAN et al. 2015).

O bombeamento de finos é considerado a ascensão partículas finas de solo do subleito para o lastro devido, também, à presença de água aliada as cargas dinâmicas durante a sua operação. Isso pode provocar a cimentação do conjunto lastro-finos quando a água evapora, e o aumento da rigidez do lastro no caso da ocorrência de material cimentante e, consequentemente, contribuir para o desgaste dos trilhos em decorrência da maior tensão transmitida pelo material rodante. Além disso, pode resultar na perda da sua capacidade de carga, devido a perda do contato entre os agregados do lastro e, consequentemente, na perda de geometria da via. Segundo Usman et al. (2015), isso impacta a qualidade de rolamento, aumentando a quantidade de manutenções e diminuindo a velocidade operacional (Figuras 7 e 8 ).

Figura 7 - Vazios do lastro preenchidos com lama devido ao bombeamento de finos

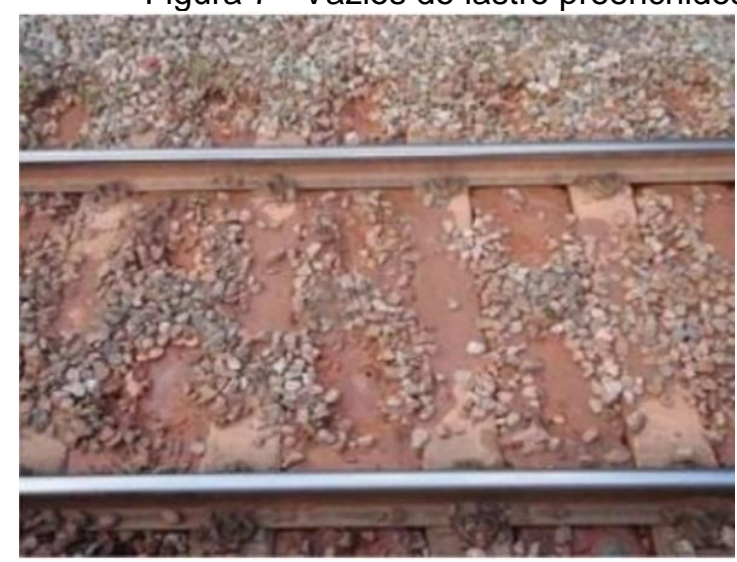

(a)

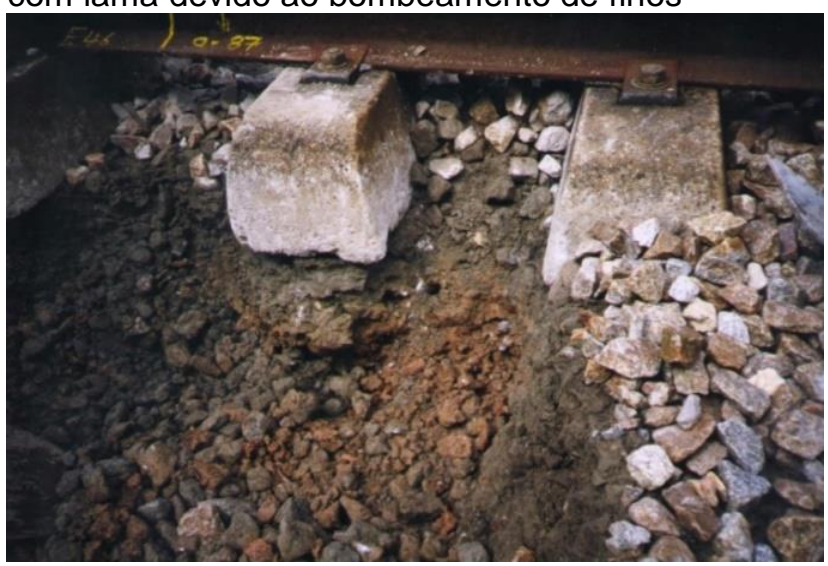

(b)

Fonte: (a) Usman et al. (2015); (b) Fortunato (2005). 
Figura 8 - Bombeamento de finos: (a) presença de água; (b) carga cíclica; e (c) prevenção

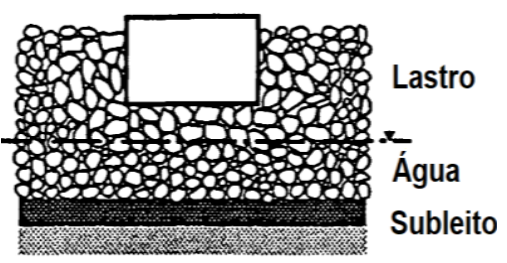

(a)

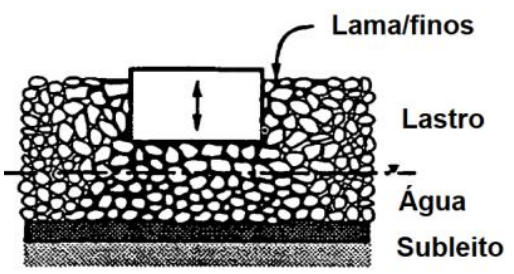

(b)

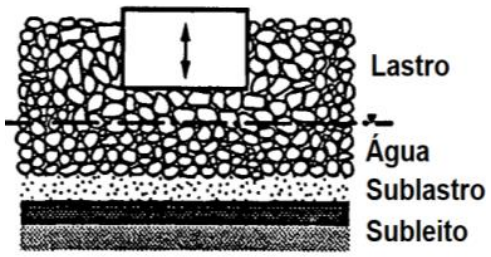

(c)

Fonte: adaptado de Li e Selig (1995).

Além desses tipos de degradação, podem ser citados também (FORTUNATO, 2005; USMAN et al., 2015): (i) liquefação, caracterizada pela perda da resistência ao cisalhamento em decorrência do aumento da pressão neutra imediata, quando a estrutura de solo granular sofre vibrações originadas da passagem dos trens; (ii) ruptura global por cisalhamento, originada pela elevada carga dos trens associada à resistência inadequada do solo e o aumento da umidade, podendo ser catastrófica; (iii) adensamento, considerada deformação volumétrica do solo induzidas pelo aumento do próprio peso do aterro construído; e (iv) expansão e contração ocasionadas pela variação de umidade (secagem e umedecimento) nos solos não saturados.

$\mathrm{Na}$ construção de novas linhas férreas, o tipo de solo, a resistência mecânica ou capacidade de suporte do subleito e as condições hidrogeológicas da região, são parâmetros que devem ser levados em consideração durante o processo de dimensionamento. A partir de uma análise acurada dessas propriedades, torna-se possível determinarem-se premissas de projeto tais como: a intensidade de carga que a via pode ser solicitada (carga por eixo), tipos dos dormentes e a espessura do lastro que deverão ser executados (PROFILLIDIS, 2006). Tal afirmação se torna verídica, à medida que projetistas devem dimensionar o subleito levando em consideração toda e qualquer variável que pode vir a modificar seu comportamento durante sua atividade.

No que se refere às linhas antigas, o aumento da carga por eixo decorrente da constante demanda de transporte de carga e da velocidade operacional passa a solicitar o subleito com tensões mais elevadas comprometendo o seu comportamento. Isso torna indispensável a análise das suas características sob a influência tanto do 
aumento da quantidade e intensidade das cargas repetidas do tráfego (PROFILLIDIS, 2006), quanto da variação da sua condição de saturação, os quais estão diretamente relacionados às variações climáticas.

Segundo Li et al. (1994) e Li e Selig (1995), tanto em linhas novas quanto em linhas antigas, as principais causas dos problemas no subleito podem ser agrupadas da seguinte forma: fatores relacionados ao carregamento, às propriedades do material de solo e ao clima.

\subsection{1. - Fator carga}

A qualidade de uma via e sua capacidade de carga ao longo tempo são influenciadas diretamente por alguns fatores tais como a carga por eixo imposta pelo veículo ferroviário, variações de temperatura e a velocidade de tráfego. Para López-Pita (2006), os tipos dos trens e do material transportado assim como sua velocidade influencia na degradação da via, pois amplificam as cargas dinâmicas e aceleram a sua deterioração.

É notório que as cargas dinâmicas ou cíclicas merecem destaque dentre as cargas atuantes na via pois geram maiores tensões verticais e dependem da velocidade, geometria e defeitos na via devido ao impacto e a vibração. Apesar de que a carga nominal por eixo de um veículo ferroviário seja medida para uma condição estática, ou seja, quando o trem está parado, são as cargas dinâmicas laterais e verticais que determinam as tensões reais solicitadas por esse mesmo veículo em uma dada velocidade sob uma via férrea.

Segundo Doyle (1980) e Fortunato (2005), o impacto vertical em decorrência da velocidade e das irregularidades e deteriorações na via (juntas, soldas, geometria e módulo de via) é um dos fatores que podem ocasionar as cargas dinâmicas. Em outras palavras, a mudança na direção do movimento da roda gera uma ação rápida no trilho que resiste a tal movimento através da sua rigidez e inércia, denominada impulso. 
Para Indraratna et al. (2011), a quantidade ou tonelagem transportada ao longo do tempo é um fator que indica possível deterioração da qualidade e do desempenho da ferrovia, sendo um indicador para possíveis manutenções e renovações necessárias. Isso quer dizer que, quanto maior a quantidade de cargas transportadas em uma via férrea, maior a probabilidade de danos e imperfeições no contato roda-trilho e nos seus componentes e a necessidade de manutenções preventivas e corretivas.

A frequência de vibração, em decorrência do carregamento dinâmico, influencia significativamente não somente no comportamento dos componentes da superestrutura, como também da subestrutura, principalmente em altas velocidades (SELIG e WATERS, 1994). Isso devido ao fato de que quanto maior a velocidade, maior se torna a intensidade ou amplitude da carga.

Baixas frequências $(0,5-1 \mathrm{~Hz})$ são causadas por defeitos oriundos do material rodante ou massa suspensa, as quais geram acelerações horizontais e verticais. Em contrapartida, elevadas frequências $(2000 \mathrm{~Hz})$ são consequências das irregularidades geométricas presentes na via (dormentes, rodas e superfície do trilho), que dependem diretamente da sua qualidade (ESVELD, 2001; PROFILLIDIS, 2006).

Os solos de subleito estão menos propensos a solicitações quando comparados com as camadas superiores de lastro e sublastro, por estarem mais distante da superfície. Por isso, usualmente, as cargas impostas na via são admitidas e analisadas na zona superior do subleito, a menos que uma região mais profunda apresente variações bruscas de umidade e densidade (INDRARATNA et al., 2011).

Apesar disso, as tensões no subleito merecem atenção significante. Trevizo (1991) relata que um aumento de 33 para 39 toneladas por eixo (18\%) faz com que as tensões e as deflexões no subleito sofram um acréscimo de $10 \%$ a 30\%, considerado elevado. $O$ autor ainda acrescenta que tal acréscimo de carga/eixo pode ser suficiente para ocasionar uma quantidade significante de manutenções ligadas a problemas no subleito em ferrovias típicas norte-americanas. 
Isso ocorre, pois, tensões maiores que a tensão de ruptura de um aterro compactado podem causar a sua deterioração, em termos de deformações permanentes, impactando diretamente a geometria da via. A Figura 9 mostra a distribuição típica de tensões no subleito, a partir da tensão de contato roda-trilho.

Figura 9 - Distribuição de tensões no subleito ferroviário

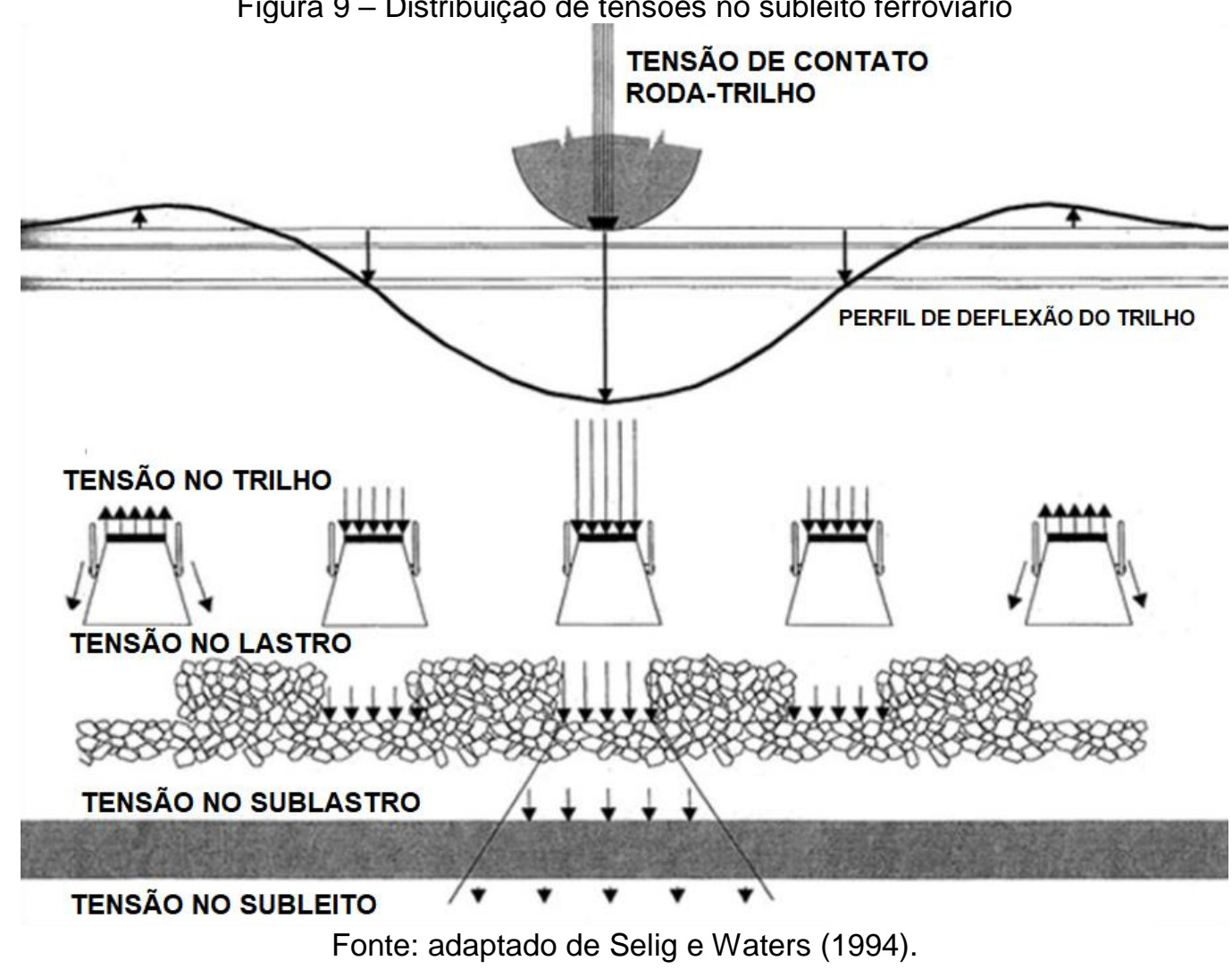

Diversos métodos foram desenvolvidos para a medição da tensão máxima no topo do subleito, com base na distribuição de tensões e deformações em duas dimensões, podendo ser encontrado no manual da AREMA (2013). Tais métodos foram desenvolvidos considerando-se a teoria da elasticidade para as camadas de lastro, sublastro e subleito, sendo transpostas em uma camada equivalente ou meio semiinfinito, o que não representa a realidade.

Apesar de simplificadora, essa análise não é representativa do que realmente acontece em campo, pois desconsidera o efeito das cargas dinâmicas características do cenário $\mathrm{HH}$ em diferentes condições de subleito, as propriedades e a heterogeneidade dos materiais granulares, como o módulo de elasticidade (E) e o coeficiente de Poisson $(\mu)$, além de qualquer tipo de deformação plástica ocorrente. 
Além disso, a AREMA (2013) recomenda que as tensões exercidas no contato sublastro/subleito devem ser inferiores a $172 \mathrm{kPa}$, para subleitos com boa capacidade de suporte. Do ponto de vista da mecânica dos pavimentos, um subleito rígido ou pouco resiliente, por deslocar-se pouco, absorve a maior parte da carga transmitida pelo tráfego, resistindo a maiores tensões. Porém, o valor estipulado pela AREMA (2013) não deve ser considerado uma regra, pois a resistência do subleito varia em função dos componentes da via, das condições operacionais, do clima e tipo de solo.

\subsection{2 - Fator solo}

Segundo Hay (1982), o subleito é composto do material solo, com diferentes propriedades quanto à composição físico-química e desempenho mecânico. O conhecimento e a aplicação adequada dos seus princípios e engenharia são significativamente importantes para projetos, construções e manutenções da via. Por isso, segundo o mesmo autor, é preciso saber qual tipo de solo utilizar em uma condição específica e como lidar com um solo já existente que não pode ser desprezado.

Com relação às características dos solos, as mesmas também estão relacionadas aos problemas no subleito ferroviário em função da existência de dois grandes grupos os quais acabam por influenciar o seu comportamento: finos (silte e argila) e granulares (areia e pedregulho).

Dentre as suas principais diferenças, o tamanho das partículas e a sua constituição mineralógica são fatores que influenciam significativamente no seu comportamento pois estão diretamente ligadas à sensibilidade do solo ao contato com a água. Os solos mais finos são mais sensíveis à presença da água que os solos granulares, se tornando mais plástico e expansivos. Segundo Lambe e Whitman (1969), isso ocorre devido a sua maior superfície específica e composição química dos argilominerais presentes em sua estrutura, como a montmorilonita, os quais proporcionam capacidade de adsorção e retenção de água particulares. 
Por outro lado, Vargas (1977) relata que os solos finos apresentam um importante parâmetro, a coesão, considerada pelo mesmo uma contribuinte à resistência ao cisalhamento fornecida pela fração argila. Ou seja, quanto maior a quantidade de finos em um solo, menor é a redução da coesão quando o mesmo se encontrar em situações de inundação comparado a solos arenosos, tendo como consequência um menor decréscimo de sua resistência. Desse modo, o comportamento dos solos coesivos é determinado pela forma e tamanho dos grãos, que depende do tipo de argilomineral presente na estrutura.

Quando se trata de tipos diferentes de solo, é importante comentar-se a respeito das classificações existentes, visto que cada sistema de classificação foi desenvolvido para expressar concisamente, sem descrições detalhadas, as características gerais dos solos da região na qual o sistema foi desenvolvido (PINTO, 2006). Isso se deve tanto às diferentes formações geológicas e pedológicas, quanto do clima local.

O mesmo autor comenta que dentre as diversas classificações de solos existentes, destacam-se o Sistema Unificado de Classificação de Solos (SUCS), muito utilizado na engenharia de barragens e o Transportation Research Board (TRB), aplicado na área de transportes. Ressalta-se que ambos os sistemas levam em consideração a granulometria e os limites de consistência (limites de Atterberg).

Considerando-se as regiões tropicais ou de clima tropical úmido, nas quais o Brasil está presente, a utilização de dos sistemas mencionados anteriormente nem sempre é recomendada, visto que muitas vezes não representam o comportamento do solo local, levando à exclusão de alguns solos de bom desempenho para a estrutura de pavimentos e desse modo, despertando dúvidas a respeito da sua adequação (BERNUCCI, 1995).

Segundo Nogami e Villibor (1995), isso é devido ao fato de que os solos tropicais possuem maiores variações mineralógicas quando comparados aos solos de regiões de clima temperado, em função do clima quente e úmido peculiar, que influenciam nos processos geológicos e pedológicos do local de origem. 
Esta afirmação faz sentido à medida que sistemas de classificação tradicionais não conseguem avaliar e visualizar as características intrínsecas dos solos tropicais, como a existência de minerais cimentantes e a sua sensibilidade à água, as quais estão relacionadas à sua gênese (alteração química, transporte e sedimentação etc.). Assim, segundo Vargas (1977), cada classificação genética do solo terá sua validade restrita às circunstâncias particulares de um determinado meio ambiente.

De acordo com o Comitê de Solos Tropicais da Associação Internacional de Mecânica dos Solos e Engenharia de Fundações, destacam-se no "meio ambiente" brasileiro, dois grandes grupos (NOGAMI e VILLIBOR, 1995): (i) saprolítico ou solo residual de alteração de rocha, resultado da decomposição in situ da rocha "mãe", mantendo de maneira nítida a estrutura desta; e o (ii) laterítico, considerado uma variedade de solos maduros superficiais evoluídos pedologicamente através do processo de lixiviação de sílica e bases da superfície, típicos das partes bem drenadas das regiões tropicais úmidas.

Segundo Bernucci (1995), os solos lateríticos são formados a partir do processo físicoquímico avançado da laterização em regiões onde há elevadas taxas de precipitação aliada às temperaturas elevadas. A mesma autora relata que, em decorrência das condições climáticas favoráveis ao rigoroso intemperismo, a fração argila dos solos lateríticos é constituída essencialmente de argilominerais do grupo mineralógico das caulinitas e de hidróxidos e óxidos hidratados de ferro e/ou alumínio.

Tais componentes, considerados agentes cimentantes, promovem estabilidade à estrutura do solo (micro e macropartículas) e conferem-lhe um comportamento peculiar quando na presença de água, tal como a redução da adsorção (BERNUCCI, 1995). Isso pode ocasionar o aumento da resistência ao cisalhamento e à compressão, devido à redução do volume dos poros, o maior entrosamento ou aproximação entre os grãos e, consequentemente, maior a força normal de contato.

Por fim, considerando-se a predominância dos solos lateríticos no Brasil, Nogami e Villibor (1981) desenvolveram uma metodologia de classificação, conhecida por MCT (Miniatura, Compactada e Tropical) a partir de pesquisas científicas e análises de 
campo com solos lateríticos do Estado de São Paulo para aplicação na pavimentação rodoviária. Assim, foram propostas duas novas classes de solo: lateríticos e não lateríticos.

\subsection{3 - Fator clima}

Além da carga atuante no solo de um pavimento e das suas características, entender o seu comportamento com relação ao clima é necessário, pois o mesmo está relacionado à variação das condições do seu estado de saturação (quantidade de água presente no sistema), este último associado com seu comportamento mecânico, devido a atuação da tensão de sucção no esqueleto do solo (diferença entre a pressão de ar e água nos solos não saturados).

É importante recordar que a ideia da influência da variação das condições climáticas em camadas de solos em pavimentação vem da época do desenvolvimento do método para o cálculo do Índice de Suporte Califórnia (CBR) pelo California Division of Highways em 1930. Tal propriedade avalia o potencial de ruptura de subleito a partir da sua capacidade de carga estática em rodovias sob condições de saturação relativas ao fenômeno do degelo da primavera norte-americana (BALBO, 2007).

Bernucci (1995), Li e Selig (1995) e Medina (1997) relatam que, em países de clima frio e temperado (temperaturas menores que $0^{\circ} \mathrm{C}$ ), a variação da temperatura do solo gerada por ciclos de congelamento e degelo, afetam o desempenho da estrutura do pavimento. Isso ocorre devido ao fato de que o solo em uma determinada condição de umidade e sucção pode sofrer contração ou expansão. Segundo Medina (1997), em regiões tropicas como o Brasil, a umidade de equilíbrio dos pavimentos tende, geralmente, a apresentar valores inferiores que a umidade ótima. Camacho (2002) cita que, em função disso, os valores de sucção do solo decrescem e, consequentemente, podem provocar a redução do módulo de resiliência.

Em ferrovias, a presença do lastro sobrejacente ao subleito torna a situação ainda mais crítica. Por ser um sistema aberto e devido a elevada permeabilidade e índice de vazios do lastro, o subleito está exposto às condições atmosféricas em todas as 
direções, favorecendo a infiltração e o acúmulo de água proveniente das chuvas. Mesmo a via possuindo uma camada de sublastro, seja ele granular, asfáltico ou laterítico, com sua função drenante, a umidade pode atingir o subleito pelas laterais da via ou mesmo pelo próprio sublastro, dependendo das suas características e condições físicas, provocando a perda de rigidez do solo.

Desse modo, a interação entre o clima e a variação das condições geotécnicas do subleito da via férrea ao longo tempo, deve ser investigada através da mecânica dos solos em condições não saturadas, considerando-se a capacidade de retenção e de infiltração de água de um perfil de solo compactado. Alguns autores pesquisaram sobre tal interação.

Ferreira et al. (2011) e Cardoso et al. (2012) analisaram a evolução de deformações no subleito ferroviário provocadas por fatores ambientais e climáticos ao longo do tempo. Para isso, utilizaram o modelo de elementos finitos CODE_BRIGHT para análises hidro-termo-mecânicas. Assim, concluíram que, as deformações permanentes podem ocorrer em função das condições climáticas e impactar a geometria da via e, por isso, devem ser consideradas na fase de dimensionamento e no planejamento de intervenções de manutenção.

Ferreira e Teixeira (2012) investigaram a influência da aplicação de diferentes soluções para sublastro (betuminoso e granular) com base no comportamento hidrotermo-mecânico da via, utilizando o mesmo modelo de elementos finitos dos autores anteriormente mencionados. A partir das análises obtidas, verificou-se que períodos chuvosos, a solução de sublastro betuminoso proporcionou reduções no grau de saturação em até 30\% comparado ao sublastro granular, apresentando uma solução eficiente contra os efeitos climáticos.

Alves (2018) ao estudarem a aplicação de sublastro betuminoso na via permanente ferroviária em comparação com o sublastro granular, verificaram que uma camada "impermeável" sobrejacente ao subleito, pode manter a umidade deste em equilíbrio, gerando um obstáculo tanto para a evaporação quanto para a infiltração. 
Cui (2016) monitorou a variação da sucção e umidade ao longo das estações do ano através de sensores de sucção instalados no interlayer (camada geotécnica formada pela mistura entre o lastro e solo de subleito) de uma via férrea para elevadas velocidades. Os dispositivos foram instalados a 20, 30 e $50 \mathrm{~cm}$ de profundidade tanto protegidos sob a via, quanto nas suas extremidades. Os resultados mostraram que o lastro, além de facilitar a presença de água no subleito, também dificulta a sua evaporação, mantendo valores baixos de sucção comparado à parte externa da via.

Hasnayn et al. (2017) simularam fenômenos de enchente e pós enchente e de procedimentos de socaria em uma via experimental de grande escala em laboratório, através da instrumentação de sensores de sucção do subleito e solicitação cíclica através de um atuador (GRAFT facility). Após as análises, os autores verificaram que o subleito merece atenção, devendo ser analisado, especialmente após períodos de chuva intensa que provocam enchentes. Além disso, concluíram que nesse período, o processo de socaria não foi efetivo, em decorrência da condição do subleito. Por fim, observaram que menores valores de sucção provocaram melhorias no desempenho da via.

Lopes (2017) analisou a aplicabilidade de quatro tipos de solos tropicais (finos e granulares, lateríticos e não lateríticos) com o objetivo de aplicá-los como sublastro de uma via permanente ferroviária a partir do entendimento das suas características hidráulicas e mecânicas. A partir dos resultados de ensaios laboratoriais e modelagem numérica de infiltração utilizando o modelo IVFlow, a autora concluiu que os solos lateríticos estudados, apresentaram elevadas sucções, baixa permeabilidade susceptibilidade a água.

Menezes et al. (2017) estudou o comportamento da umidade do solo de subleito ferroviário quando submetido à precipitação para diferentes perfis de plataforma através do mesmo modelo numérico utilizado pela autora mencionada no parágrafo anterior. Concluiu-se que o solo não restringiu a percolação de água e que o perfil de subleito em via singela com aterro obteve desempenho superior aos demais perfis estudados quanto a infiltração de água da chuva. 
A inexistência de um sistema de drenagem eficiente na via acarreta variações nas suas respostas mecânicas em função das variações climáticas, induzindo deformações permanentes significativas além de outros defeitos nos componentes da via, especialmente nas suas camadas geotécnicas (LÓPEZ-PITA et al., 2006).

Consequentemente, tais deformações ocasionam variações nos parâmetros geométricos, que estando fora dos limites prescritos em norma, podem causar interrupções ao tráfego (PIRES, 2015). Desse modo, percebe-se que é preponderante entender-se como funciona a relação via-clima, ou seja, de que modo a água proveniente do ciclo hidrológico interage e interfere no estado e comportamento dos solos não saturados.

\section{3 - Os solos não saturados}

Diferentemente dos solos saturados $(S=100 \%)$ ou completamente secos ( $\mathrm{S}=0 \%$ ), com duas fases (água e sólidos ou ar e sólidos, respectivamente), a condição não saturada $(0 \%>S>100 \%)$ é composta por quatro, tais como água, ar, sólidos e menisco (interface água/ar) (FREDLUND e MORGENSTERN, 1977; FREDLUND et al., 1978).

Segundo Fredlund (1996), a partir de tais conhecimentos, o mundo geotécnico ficou dividido pelo nível horizontal do lençol freático, em duas partes: abaixo do nível ou zona saturada, e acima ou zona não saturada. A Figura 10 mostra um exemplo de um elemento de solo não saturado.

Figura 10 - Elemento de um solo não saturado

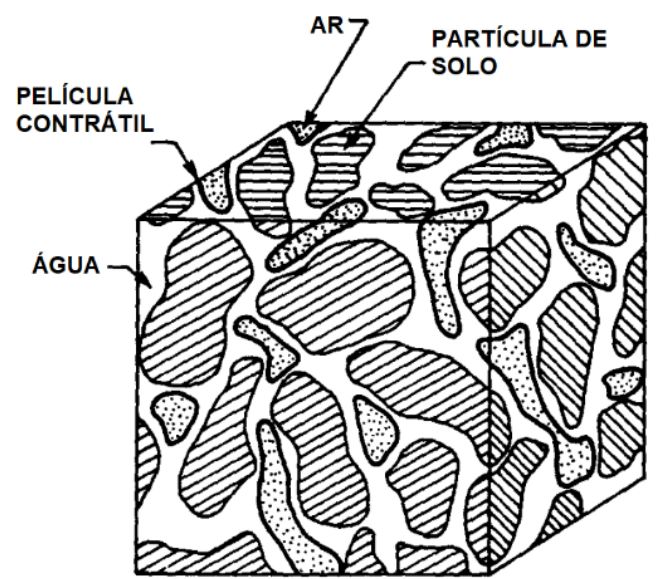

Fonte: adaptado de Fredlund e Morgenstern (1977). 
A zona saturada compreende a região onde a poropressão é positiva e o comportamento do solo é governado pela tensão efetiva $\left(\sigma-u_{w}\right)$. Com relação à zona não saturada, o comportamento mecânico do solo é governado por duas variáveis independentes, a tensão normal efetiva $\left(\sigma-u_{a}\right)$ e a sucção matricial ( $\left.u_{a}-u_{w}\right)$ (Figura 11).

Figura 11 - A mecânica dos solos não saturados: (a) no mundo; (b) classificação

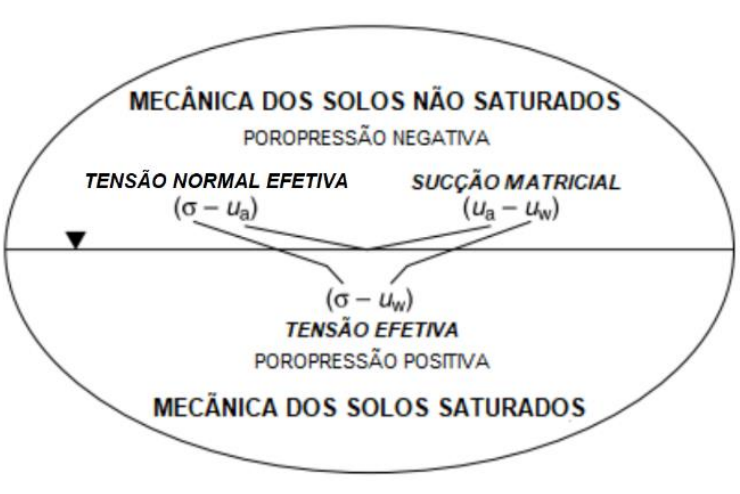

(a)

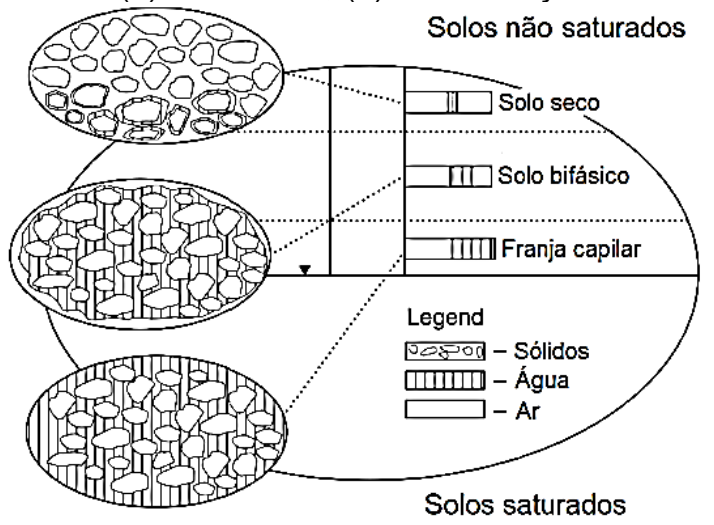

(b)

Fonte: adaptado de Fredlund (1996)

\subsection{1 - Sucção}

A sucção é a quantidade de energia necessária para absorver ou reter água no interior do solo quando há água livre para fluir (LEE e WRAY, 1995). Para Stuermer (1998), a sucção no solo é a força necessária para movimentar a água contida nele e pode ser dividida em sucção matricial $\left(\psi_{m}\right)$ e a sucção osmótica ( $\left.\psi_{o}\right)$ (Equação 1$)$.

$$
\psi_{t}=\psi_{m}+\psi_{o}
$$

Onde:

$\psi_{t}-$ sucção total;

$\psi_{m}$ - sucção matricial;

$\psi_{o}$ - sucção osmótica.

A sucção matricial é resultante da combinação da capilaridade (macroestrutura) com as forças de adsorção (microestrutura). A sucção osmótica é caracterizada por uma tensão adicional no sistema trifásico, provocada por diferentes concentrações de sais 
presentes dissolvidos na fase líquida (FREDLUND e RAJARDJO, 1993; MARINHO, 1997).

\section{Sucção matricial}

Para compreender o significado da sucção matricial no solo, é necessário primeiramente entender o fenômeno da capilaridade. Considerando-se um tubo de pequeno diâmetro em contato com uma superfície livre de água, até a mesma subir e atingir uma posição de equilíbrio, forças de adsorção entre a água e o vidro do tubo aliadas à baixa pressão atmosférica dentro do mesmo fazem com que a água suba. Quanto maior o raio do tubo, menor é a altura de água (h) (CARDOSO, 2006).

Assim, a altura que a água consegue alcançar depende da natureza do material do solo em questão e o diâmetro dos vazios. Como pode ser observado na Figura 12, à medida que a altura da coluna de água se eleva, maior é a tensão superficial necessária para sustentar tal coluna.

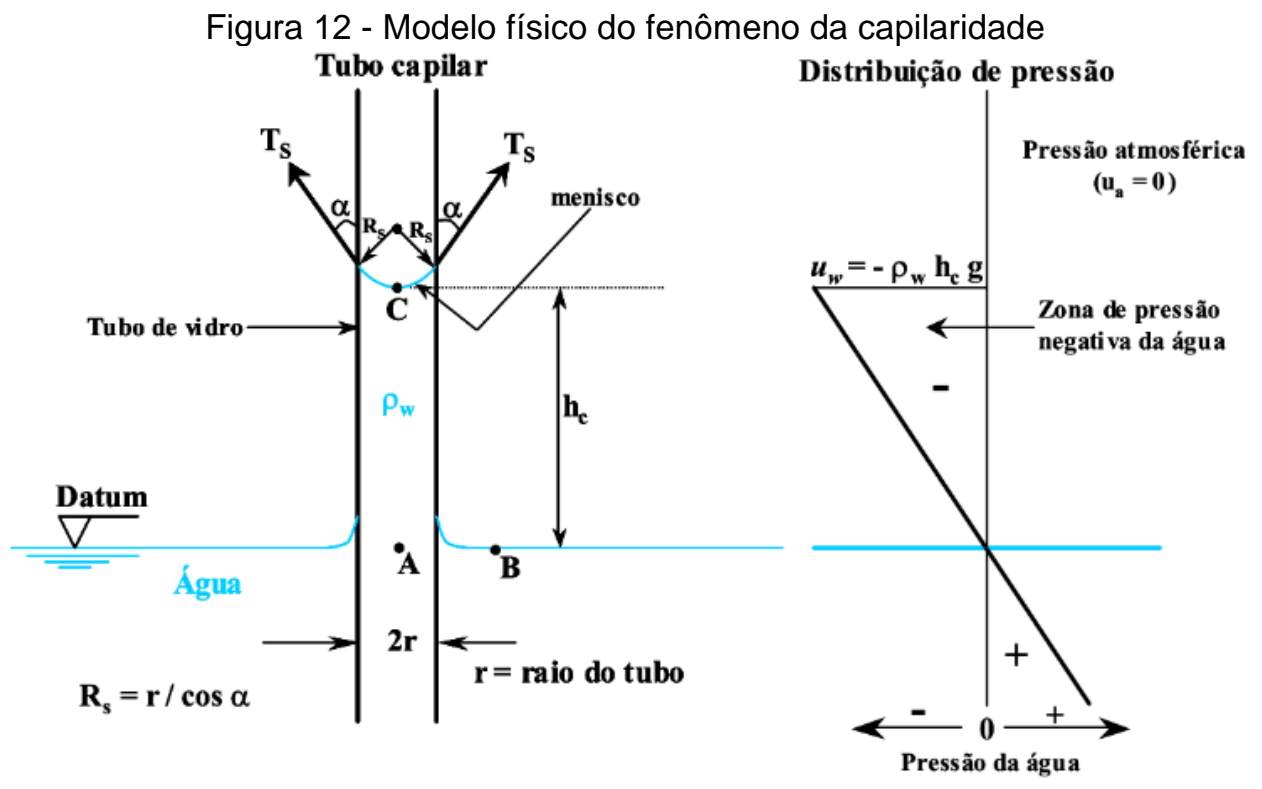

Fonte: Mendes (2008).

A partir do modelo da Figura 12, considerando o somatório das forças verticais, é possível a obtenção da máxima altura de ascensão de água, $h_{c}$, a qual é representada pela Equação (2).

$$
h_{c}=\frac{2 T_{S}}{\rho_{w} g R_{S}}
$$


Onde:

$h_{c}$ - altura da coluna d'água;

$T_{S}$ - tensão superficial da água;

$g$ - aceleração da gravidade;

$R_{S}$ - é o raio de curvatura do menisco;

$\rho_{w}$ - massa específica da água.

Além disso, pode-se observar a partir da mesma Figura 12, que os pontos A, B e C estão em equilíbrio hidrostático (MENDES, 2008). Nessas condições, qualquer ponto de água acima do ponto A apresenta pressão negativa, de sustentação da coluna de água, enquanto que abaixo do ponto em questão, a pressão é positiva, em decorrência da pressão hidrostática. No ponto $\mathrm{C}$, a pressão do ar é correspondente à atmosférica e a pressão da água é negativa e igual à sucção matricial (Equação 3).

$$
\psi_{m}=-u_{w}=\left(u_{a}-u_{w}\right)=\rho_{w} g h_{c}=\frac{2 T_{s}}{R}
$$

Para o caso de o menisco apresentar dois raios de curvatura, a Equação (4) pode ser representada pela Equação (4) (LU e LIKOS, 2004).

$$
\psi_{m}=\left(u_{a}-u_{w}\right)=T_{s}\left(\frac{1}{R_{1}}+\frac{1}{R_{2}}\right)
$$

Onde:

$\Psi_{m}$ - sucção matricial;

$T_{S}$ - tensão superficial da água;

$u_{a}$ - pressão do ar;

$u_{w}$ - pressão da água;

$R_{1}$ - é o raio de curvatura do menisco menor;

$R_{2}$ - é o raio de curvatura do menisco maior.

O raio de curvatura $\left(R_{s}\right)$ é semelhante ao raio dos poros de um solo. Quanto menor for o raio dos seus poros, maior será a sucção matricial e vice-versa (Figura 13). 
Figura 13 - Fenômeno da capilaridade por meniscos capilares

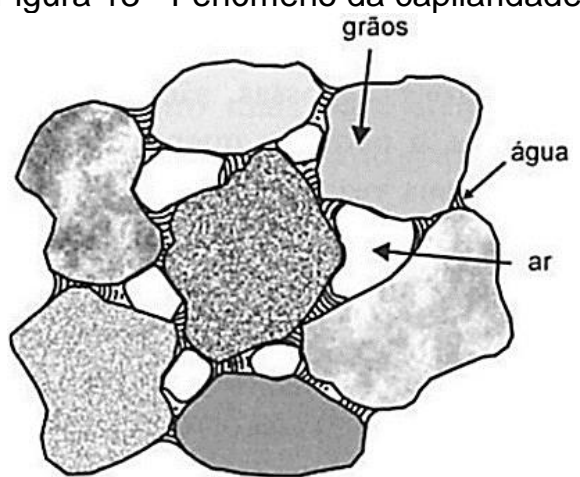

(a)

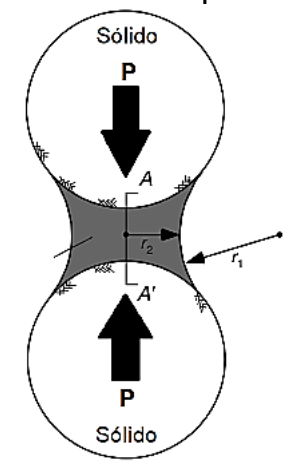

(b)

Fonte: adaptado de (a) Pinto (2006); (b) Lu e Likos (2004).

Pinto (2006) comenta que esses meniscos, através da tensão superficial negativa da água ou sucção matricial (força P), tende a aproximar as partículas do solo, surgindo dessa forma, um aumento da componente normal ou uma coesão aparente a qual tende a influenciar diretamente no seu estado de tensões e no seu comportamento mecânico, aumentando a resistência ao cisalhamento.

Marinho (1997) diz que a sucção também pode ser definida em função da umidade relativa do ar, ou seja, em função das pressões parcial e de saturação do vapor de água dos poros (Equação 5). Para a determinação da sucção, é necessário determinar-se a energia livre total da água intersticial a um determinado valor de umidade, que está diretamente relacionada com a energia de vapor livre. Esta última, varia em função da umidade relativa, ou seja, quanto maior a sucção, maior será a umidade relativa do ar, e menor a energia livre da água nos poros.

$$
\psi_{m}=\frac{R T}{v_{w 0} w_{v}} \cdot \ln \left(\frac{u_{v}}{u_{v 0}}\right)
$$

Onde:

$\psi_{m}$ - sucção matricial;

$R$ - constante universal dos gases;

$T$ - temperatura absoluta;

$v_{w 0}$ - massa molecular do vapor de água dos poros;

$u_{v}$ - pressão parcial de vapor de água nos poros;

$u_{v 0}$ - pressão de saturação do vapor de água nos poros. 


\section{Sucção osmótica}

Segundo Marinho (1997), a sucção osmótica ou pressão osmótica ( $\psi_{\mathrm{o}}$ ) é a parcela da sucção total causada por efeitos osmóticos sendo função da concentração química da água no interior do solo. Em outras palavras, solutos presentes no solo tendem a manter ou prender a água nos seus interstícios, segurando-a e evitando de escapar através da evaporação. A tensão ou pressão necessária para extrair uma quantidade infinitesimal de água desse meio é denominada sucção osmótica.

A influência e importância da sucção osmótica no comportamento mecânico dos solos não saturados foi estudado por vários autores e admitida não tão importante - talvez insignificante - quanto à sucção matricial. Por isso, somente a sucção matricial foi considerada neste trabalho, considerada suficiente para descrever o comportamento dos solos não saturados, e igual à sucção total (FREDLUND e RAHARDJO, 1993).

\subsection{2 - Curva característica do solo}

A curva característica (SWCC - Soil Water Characteristic Curve) é a relação constitutiva entre a sucção $(\psi)$ e a umidade volumétrica $(\theta)$ ou grau de saturação $(S)$ do solo (Equação 6). É um parâmetro muito utilizado na geotecnia, com o intuito de representar o comportamento dos solos não saturados e permitindo avaliar a capacidade de retenção de água nos seus poros.

$$
\theta=\frac{S e}{1+e}=S \eta=\gamma_{d} w
$$

Onde:

$S$ - grau de saturação;

$e$ - índice de vazios;

$\eta$-porosidade;

$\theta$ - umidade volumétrica;

$w$ - umidade gravimétrica;

$\gamma_{d}$ - massa específica aparente seca do solo. 


\section{Parâmetros da curva característica do solo}

Segundo Van Genuchten (1980), a curva característica pode ser definida por quatro parâmetros, sendo destacados: umidade volumétrica saturada $\left(\theta_{s}\right)$, umidade volumétrica residual $\left(\theta_{r}\right)$, a sucção de entrada de ar $(1 / \alpha)$ e a curva de dessorção ou secagem $(\Delta \psi / \Delta \theta)$.

A pressão ou sucção de entrada de ar representa a diferença entre as pressões de água e ar necessária para drenar o poro de maior dimensão do solo. Por outro lado, a pressão de início do estágio residual corresponde à pressão necessária para gerar uma remoção adicional de água do solo, por isso sendo representada por valores elevados. A Figura 14 mostra um exemplo de uma curva característica de retenção de água no solo.

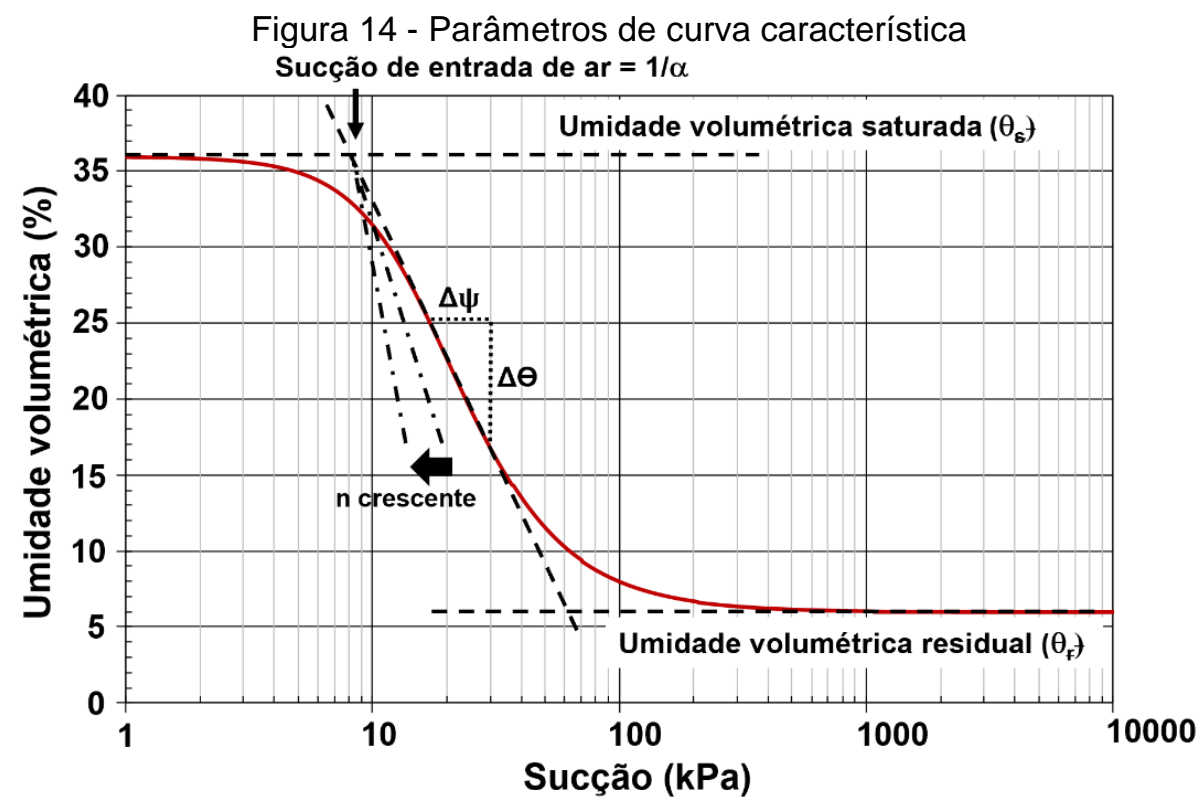

Assim a curva característica passa a ser dividida em três estágios (FREDLUND e RAHARDJO, 1993):

- Estágio saturado ou antes da entrada de ar: a sucção no solo aumenta, porém ainda é muito baixa, de modo que a umidade volumétrica permanece a mesma e as forças capilares mantêm a água no interior dos maiores poros, evitando a drenagem;

- Estágio de transição ou após a entrada de ar: os poros maiores do solo começam perder água, permitindo a entrada de ar. Desse modo, a tensão de sucção aumenta, 
aproxima as partículas e diminui o tamanho dos seus poros, reduzindo a umidade consideravelmente. Vazios com de diâmetro menores se esvaziam e concentram a água em elevadas sucções;

- Estágio residual: sucções elevadas e baixos valores de umidade restringem ainda mais a drenagem da água. Tal estágio é considerado o limite inferior a partir do qual qualquer aumento da sucção, pouco afeta os valores de umidade.

O valor da entrada de ar pode ser obtido através de um procedimento gráfico proposto por Fredlund e Xing (1994). Sua determinação é feita pela intercessão entre a reta horizontal, correspondente à umidade volumétrica saturada, com a reta tangente que passa pelo ponto de inflexão da curva. De outro modo, o teor de umidade volumétrica residual pode ser determinado pela intercessão desta última com a reta tangente a curva que passa pelo valor de sucção de $10^{6} \mathrm{kPa}$.

Segundo Oliveira (2004), não existe um valor exato para a umidade residual e que ela é considerada por alguns autores como 0 ponto de murcha ${ }^{1}$ das plantas, correspondente a $1500 \mathrm{kPa}$.

\section{Fatores que influenciam a curva característica do solo}

Devido a diferenças entre os diversos tipos de solos existentes, a curva apresenta características diferentes, que dependem da macro e microestrutura do solo (contato entre as partículas), entrada de ar e variações volumétricas (LU e LIKOS, 2004).

Esta curva é a ferramenta base e crucial na análise do comportamento hidromecânico de um solo não saturado. Fornece informações que facilita o entendimento das propriedades do solo, como a condutividade hidráulica e térmica (análises de fluxo de água, ar e calor), resistência ao cisalhamento tanto quanto o módulo de resiliência (RODRIGUES, 1997).

\footnotetext{
${ }^{1} \mathrm{Na}$ agricultura, ponto de murcha permanente é o conteúdo de água presente no solo de tal modo que abaixo dele a planta não consegue mais extraí-la ou sugá-la. Ou seja, o solo está tão seco e com elevadas sucções, que a pequena quantidade de água existente permanece aderida fortemente às partículas de solo.
} 
Dentre os fatores que influenciam na sucção ou na forma da curva característica, podem ser relatados (FREDLUND e RAHARDJO, 1993; RODRIGUES, 1997):

- Granulometria e mineralogia do solo: a granulometria está relacionada à sucção em função da curva de retenção ou característica. Solos finos ou argilosos, por apresentarem alta capacidade de armazenamento de água, precisam de valores elevados de sucção para obter uma diminuição no seu grau de saturação (elevado valor de entrada de ar). Já os solos arenosos, possuem mais facilidade em perder a água retida em seus poros maiores, devido ao tamanho das suas partículas, necessitando de menores valores de sucção para ocorrer a dessaturação (VANAPALLI et al., 1999) (Figura 15).

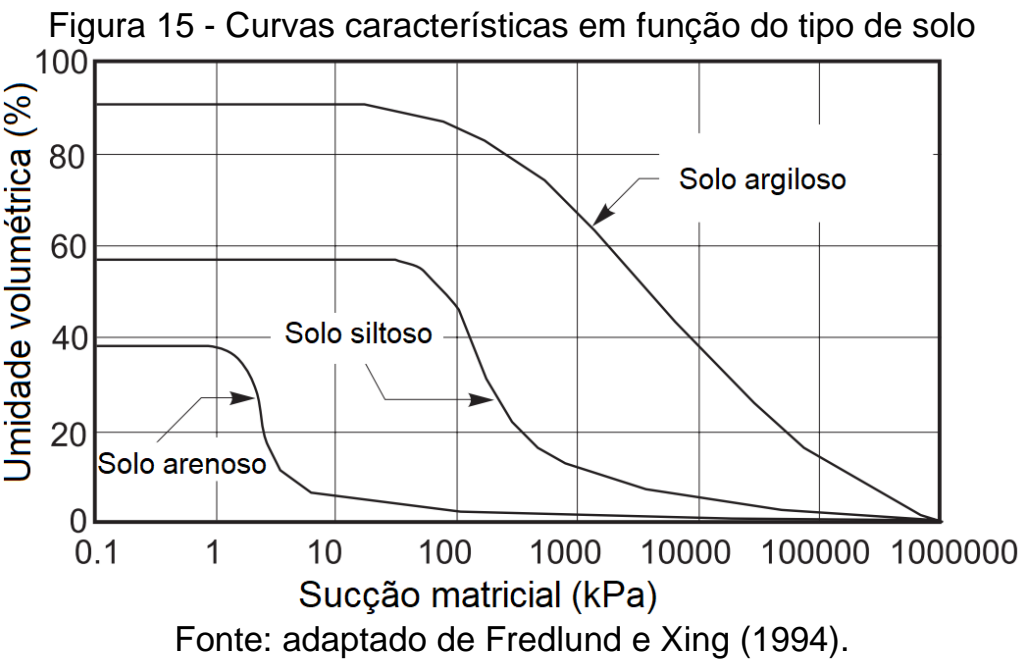

- Estrutura do solo: a sucção ou energia necessária para remover uma parte infinitesimal de água de um solo é dependente do tamanho dos seus poros e da tensão superficial entre suas partículas. Poros maiores exigem energias menores. Desse modo, para tensões superficiais constantes, a sucção necessária para a remoção de água depende da estrutura do solo (PHILLIP, 1996). Segundo Gerscovich (2001), quando o solo passa pelo processo de compactação no ramo úmido, o volume de vazios se torna reduzido e homogêneo, prevalecendo assim poros de pequenos diâmetros que passam a controlar o seu esqueleto. Dessa forma, a capacidade de retenção de água e a resistência à dessaturação do solo são maiores, passando a ser controladas pela microestrutura. Por outro lado, quando o solo possui estruturada 
após ser compactado no ramo seco, as agregações ou clusters formam grande poros interconectados, sendo controlado pela macroestrutura (Figura 16).

Figura 16 - Efeito da estrutura na sucção do solo

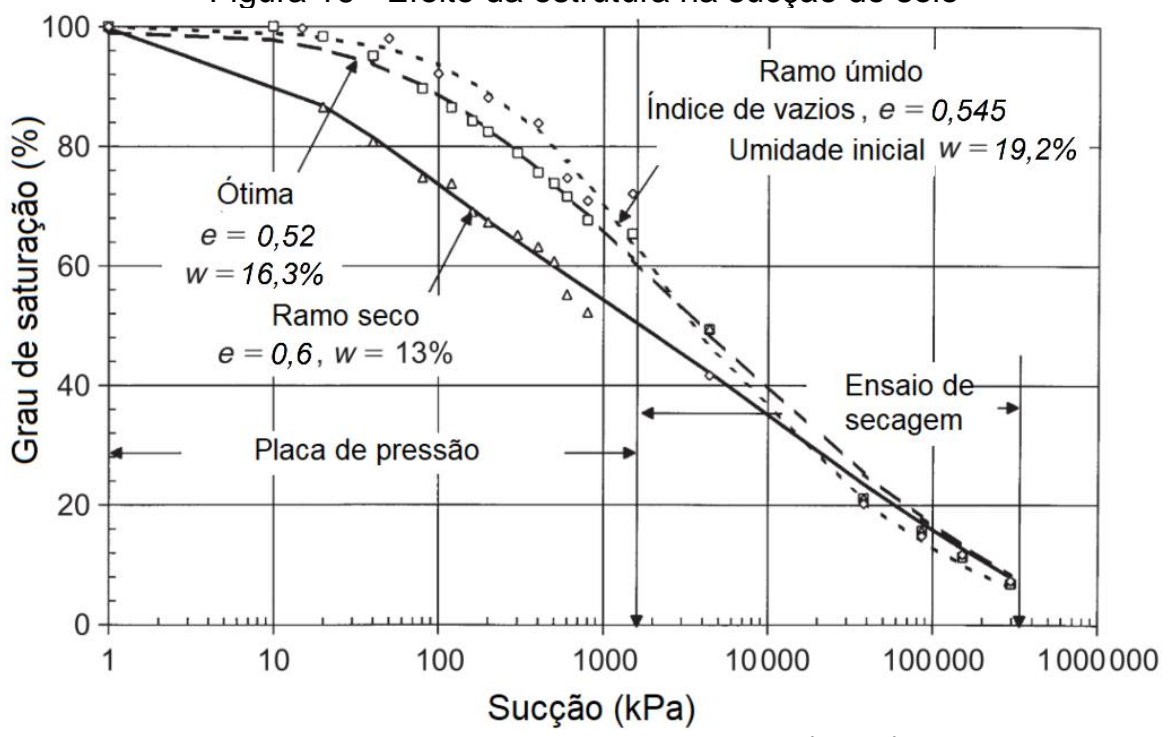

Fonte: adaptado de Vanapalli et al. (1999).

- Ciclo de umedecimento e secagem (histerese): a curva característica de uma amostra de solo varia em função da histerese, ou seja, a umidade é maior em um processo de secagem do que a observada no processo de umedecimento para um mesmo solo (GERSCOVICH, 2001). A Figura 17 apresenta o gráfico de uma histerese.

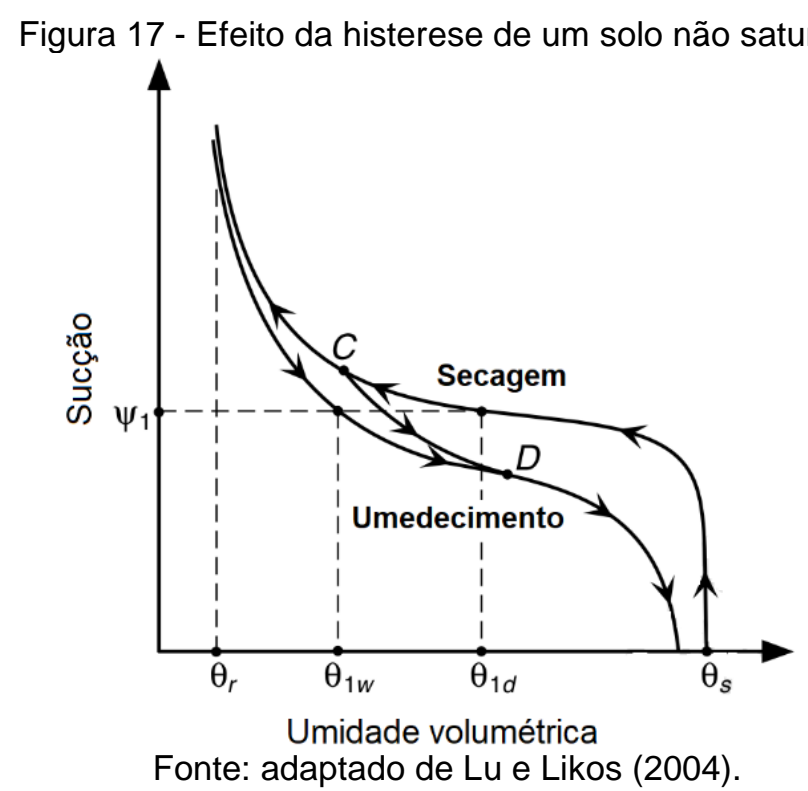

Esse fenômeno ocorre devido à não uniformidade geométrica dos vazios, da presença de ar ou mesmo alguma possível mudança ou rearranjo estrutural decorrente do 
ressecamento ou inchamento do solo durante o fluxo de água e ar (HILLEL ${ }^{2}, 1971$ apud GERSCOVICH, 2001).

\section{Modelos matemáticos para o ajuste da curva característica do solo}

Como foi dito, o estudo e caracterização de um dado meio poroso não saturado exige a determinação da curva característica de retenção de água. Tal curva é obtida em laboratório utilizando diversas técnicas que serão abordadas nos próximos tópicos.

Segundo Machado e Zuquette (2004), para se utilizarem as informações provenientes de ensaios laboratoriais em análises numéricas de fluxo, resistência, balanço hídrico e determinação da umidade de campo, é necessário ajustá-las através de ajustes matemáticos. Tais ajustes podem ser realizados utilizando várias formulações encontradas na literatura (BROOKS e COREY, 1964; VAN GENUCHTEN, 1980; FREDLUND e XING, 1994).

No presente trabalho, foi utilizada a equação proposta por Van Genuchten (1980) (Equação 7). Os principais parâmetros associados com esta equação foram apresentados, de forma simplificada, na Figura 14.

$$
\theta=\theta_{r}+\frac{\theta_{s}-\theta_{r}}{\left[1+|\alpha \psi|^{n}\right]^{m}} ; \quad m=1-\frac{1}{n}
$$

Onde:

$\theta_{r}$ - umidade volumétrica residual;

$\theta_{s}-$ umidade volumétrica saturada;

$\alpha$ - sucção correspondente à entrada de ar;

$\psi$ - sucção matricial;

$n$ e $m$ - constantes empíricas.

${ }^{2}$ HILLEL, D. Soil and water: physical principles and processes. New York: Academic Press, INC, 288p, 1971. 
Gerscovich e Sayão (2002) relatam e comentam sobre a aplicabilidade dessas equações no ajuste de dados experimentos obtidos com 11 solos brasileiros. $O$ modelo de Van Genuchten (1980) foi um dos que apresentaram os melhores ajustes.

Os ensaios laboratoriais utilizados para a obtenção dos dados da curva característica possuem relativamente elevado custo e ao mesmo tempo são considerados laboriosos. Levando em consideração tal afirmação, modelos preditivos foram desenvolvidos para se estimar a curva característica do solo, como a proposta por Aubertin et al. (2003), utilizada neste trabalho (Equação 8).

$$
S_{r}=\frac{\theta}{\eta}=S_{c}+S_{a}^{*}\left(1-S_{c}\right)
$$

Onde:

$\theta$ - umidade volumétrica;

$S_{c}$ - grau de saturação referente à capilaridade, a qual depende exclusivamente dos diâmetros dos poros e da distribuição dos poros;

$S_{a}^{*}$ - grau de saturação referente à adesão, a qual está associada a fina membrana de água que envolve a partícula de solo e depende da sucção $(\psi)$, tamanho da partícula $\left(D_{10}\right.$ e $\left.D_{60}\right)$, coeficiente de não uniformidade $(C N U)$ e da porosidade do solo $(\eta)$; $\eta$ - porosidade.

Aubertin et al. (2003) propôs uma equação para estimar a curva característica a partir de propriedades básicas dos materiais geotécnicos tais como a distribuição granulométrica $\left(D_{60}\right.$ and $\left.D_{10}\right)$, umidade volumétrica saturada $\left(\theta_{\mathrm{s}}\right)$ e limite de liquidez (LL). Esta equação é uma modificação do método de Kovacs (1981), baseado na representação do grau de saturação, considerando componentes de capilaridade e adesão.

De uma forma geral, os modelos de estimativa da curva característica se baseiam no conceito de similaridade da mesma com a distribuição granulométrica, que indiretamente está relacionada à distribuição do volume de vazios e do tamanho dos poros. Apesar disso, tal similaridade não considera o arranjo estrutural, a uniformidade 
geométrica dos vazios e a inexistência da variação de volume nos processos de umedecimento e secagem (GERSCOVICH, 2001).

\subsection{3 - Condutividade hidráulica}

Como já foi mencionado, a umidade volumétrica do solo diminui à medida que a sucção aumenta e vice-versa. O decréscimo de umidade ocorre devido ao aumento do volume de ar no interior dos poros do solo.

O aumento do volume de ar gera uma descontinuidade da fase da água, desse modo, reduzindo caminhos disponíveis para a percolação da água e consequentemente impactando a condutividade hidráulica não saturada do sistema (PARK e FLEMING, 2006).

Para Fredlund et al. (1994), a condutividade hidráulica é a propriedade mais variável da engenharia geotécnica, podendo variar mais de 10 ordens de magnitude, desde materiais mais permeáveis como pedregulhos até os menos permeáveis como as argilas, sendo considerado o maior obstáculo na análise de problemas de infiltração.

Diferentemente do solo saturado, o qual possui condutividade hidráulica máxima e constante, tal condutividade hidráulica no solo não saturado depende do teor de umidade volumétrica $(\theta)$ e do grau de saturação $(S)$, os quais estão relacionados à sucção $(\psi)$. A função de condutividade hidráulica $K(\psi)$ (relação entre sucção e o coeficiente de permeabilidade) pode ser definida através de resultados de ensaios laboratoriais.

Assim como a curva de retenção, o tempo e o custo são obstáculos para a obtenção direta ou experimental da curva ou função condutividade hidráulica, necessitando dessa forma a sua estimativa e ajustes através de métodos indiretos. Tais métodos podem ser relações constitutivas ou modelos estatísticos obtidos com mais frequência em laboratório, como a curva característica. Neste trabalho foi utilizado a função semiempírica de condutividade hidráulica, que teve como base a equação de ajuste da 
curva característica proposta por Van Genuchten (1980) referida anteriormente (Equação 9).

$$
(\Theta)=\frac{k(\Theta)}{k_{s a t}}=\Theta^{\frac{1}{2}}\left[1-\left(1-\Theta^{\left(\frac{1}{m}\right)}\right)^{m}\right]^{2}
$$

Onde:

$\Theta-\frac{\theta-\theta_{r}}{\theta_{s}-\theta_{r}}=$ teor de umidade volumétrica normalizada;

$k(\Theta)$ - condutividade hidráulica para um determinado valor de $\Theta$;

$k_{\text {sat }}$ - condutividade hidráulica saturada;

$\Theta_{S}$ - umidade volumétrica normalizada saturada.

Segundo Mendes (2008), os modelos estatísticos levam em consideração a dependência da condutividade hidráulica e da curva característica com relação à porosimetria e o tipo de solo em questão. Além disso, todos os modelos propostos na literatura em geral necessitam de quatro variáveis: os teores de umidade volumétrico saturado $\left(\theta_{s}\right)$ e residual $\left(\theta_{r}\right)$, valor da sucção da entrada de ar e o coeficiente de permeabilidade ou condutividade hidráulica saturada.

\subsection{4 - Métodos de medida e controle da sucção}

Considerando-se a importância da sucção matricial para solução de problemas em obras geotécnicas (hidráulicos e mecânicos), a sua medição em solos não saturados foi um grande avanço, tanto para a obtenção da curva característica com amostras em laboratório, quanto em situações de campo. Segundo Fredlund e Rahardjo (1993) e Marinho (1997), diversos métodos foram propostos com a finalidade de se determinar a relação constitutiva entre a sucção $(\psi)$ e a umidade volumétrica $(\theta)$ dos solos. Tais métodos podem ser classificados em diretos e indiretos, os quais variam em função do tipo de sucção medida, o intervalo de medição e o tempo de equilíbrio com o solo.

Os métodos diretos de medição da suç̧ão são realizados com base na medição da resistência à tração da água nos poros. Por outro lado, os métodos indiretos são 
aqueles realizados com base na determinação de parâmetros, como a umidade relativa e as condutividades elétrica e hidráulica, os quais são relacionados com a sucção através de equações de calibração (conversão de medições de um sinal para outro). A Tabela 1 resume alguns dos métodos existentes de medida e controle de sucção, tanto quanto sua componente de sucção medida e o tempo de aquisição ou sensibilidade ao equilíbrio com o solo.

Tabela 1 - Técnicas para medição de sucção em solos

Técnica

Medida de sucção Intervalo $(\mathrm{kPa})$ Tempo de equilíbrio

\begin{tabular}{cccc}
\hline Psicrômetro & total & 100 a 71000 & minutos \\
\hline Papel filtro (com contato) & matricial & 30 a 30000 & 7 dias \\
\hline Papel filtro (sem contato) & total & 400 a 30000 & $7-14$ dias \\
\hline Sensor de condutividade térmica & matricial & 30 a 3000 & semanas \\
\hline Placa de sucção & matricial & 0 a 90 & semanas \\
\hline Placa de pressão & matricial & 0 a 1500 & horas \\
\hline Tensiômetro padrão & matricial & 0 a 100 & minutos \\
\hline Tensiômetro osmótico & matricial & 0 a 1500 & horas \\
\hline Tensiômetro tipo Imperial College & matricial & 0 a 1800 & minutos
\end{tabular}

Fonte: adaptado de Fredlund e Rahardjo (1993), Ridley e Wray (1995) e Marinho (1997).

Segundo Rodrigues (1997), a verificação e escolha de tais métodos dependem de quatro fatores: precisão, custo, complexidade de procedimento e o tempo para a realização dos ensaios. Como mencionado, vários são os métodos de medição de sucção, sendo destacados neste presente trabalho: placa de sucção, placa de pressão, papel filtro e sensores de medição do potencial matricial do solo.

As técnicas da placa de pressão e sucção e do papel filtro utilizados na obtenção da curva característica em laboratório são consideradas rotineiras. Isso ocorre devido aos seus intervalos de medição da sucção, sendo possível, dessa forma, obter-se a curva inteira: placa de sucção (de 0 até $30 \mathrm{kPa}$ ), placa de pressão (de 30 a $400 \mathrm{kPa}$ ) e papel filtro para pressões superiores à $400 \mathrm{kPa}$ (MARINHO, 1994).

Com relação às medições da sucção em campo, alguns instrumentos foram desenvolvidos, como o tensiômetro, considerado uma técnica de medição direta 
(RIDLEY e BURLAND, 1993; FREDLUND e RAHARDJO, 1993; MARINHO, 1997). Tal método apresenta limitações e dificuldades, como a realização de medições em um número elevado de locais em campo além do baixo intervalo de leitura.

Em função da necessidade de equipamentos mais flexíveis (práticos), sensores de medição indireta do potencial matricial do solo foram desenvolvidos (FREDLUND e RAHARDJO, 2012). Tais sensores são inovações (significativas) de um dos mais antigos sensores para medição de sucção matricial, conhecido por bloco poroso de gesso.

O bloco poroso de gesso se baseia no princípio de que a sua umidade causa variações na resistência ou condutividade elétrica dos seus poros. A partir de um resistor elétrico no interior do gesso, se torna possível inferir a sucção em função da sua umidade, que é a mesma umidade do solo ao entrar em equilíbrio com o mesmo. A correlação entre a resistividade ou condutividade elétrica e a sucção é denominada calibração. Em outras palavras, quanto maior a quantidade de água em um meio poroso, maior o fluxo de corrente elétrica, ou seja, menor a resistência elétrica e, consequentemente, menor a sucção devido a maior teor de umidade.

Segundo Fredlund e Rahardjo (2012), o gesso foi considerado o meio poroso mais adequado para a medição da resistência elétrica, pois a velocidade do seu processo de saturação é elevada, possui baixo intervalo de equilíbrio o que melhora sua sensibilidade e excelente condutividade elétrica quando em contato com a água.

Mais detalhes com relação a outros métodos de medição e controle de sucção foram apresentados na literatura e podem ser encontrados em Fredlund e Rahardjo (1993), Ridley e Wray (1995), Marinho (1997) e Fredlund e Rahardjo (2012).

\section{Placa de sucção}

O método da placa de sucção se baseia na imposição de valores de sucção diretamente ao solo através da diferença de cotas entre uma placa porosa e um reservatório de água, a qual induz o equilíbrio hidráulico entre a placa porosa e o corpo 
de prova (CP). Se a placa estiver com sucção menor que a amostra de solo, ou seja, com maior teor de umidade, a água tende a fluir da placa para a amostra (Figura 18).

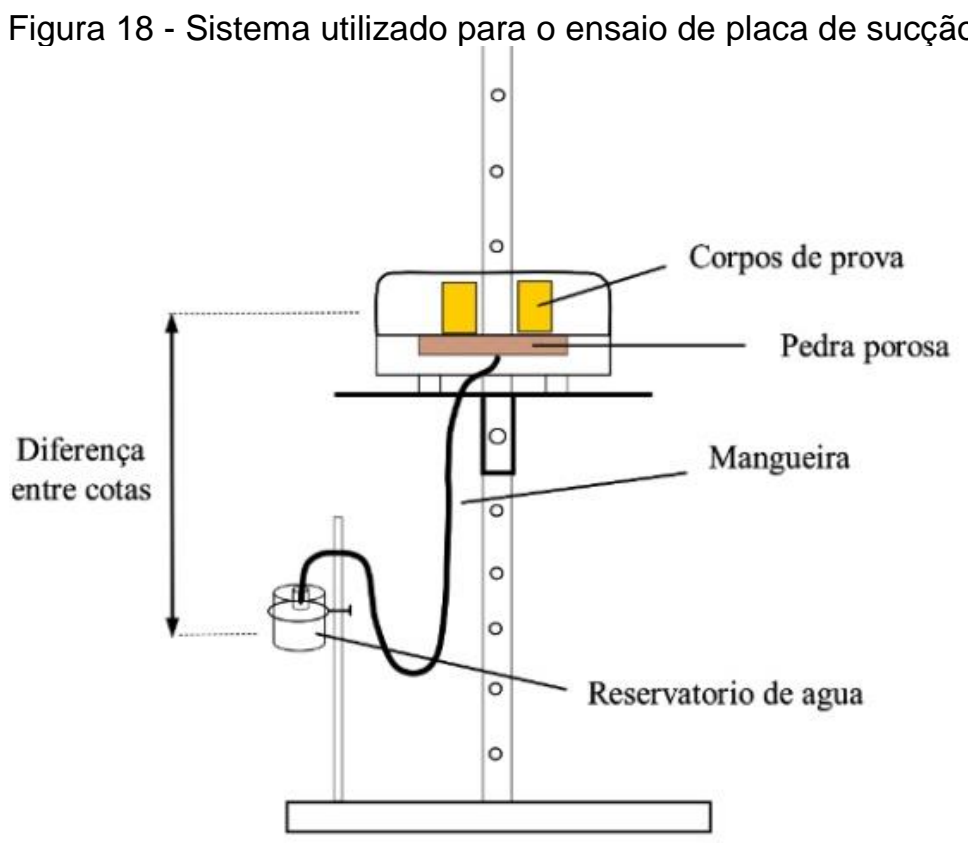

Fonte: Cardoso (2006)

As pedras porosas que devem ser utilizadas nesse ensaio devem possuir o valor da entrada de ar elevado de tal forma que a pedra permaneça saturada constantemente, sem passagem de ar (CARDOSO, 2006). A presença de ar no sistema dificultaria o fluxo de água pelo mesmo. A Equação 10 mostra o cálculo da sucção matricial.

$$
u_{a}-u_{w}=\rho_{w} * g *\left(z_{a}-z_{b}\right)
$$

Onde:

$u_{a}$ - pressão do ar;

$u_{w}$ - pressão da água ou poropressão;

$\rho_{w}$ - massa específica da água;

$g$ - aceleração da gravidade;

$z_{b}$ - altura da amostra de solo;

$z_{a}-$ altura do reservatório de água.

CARDOSO (2006) comenta que a altura máxima que a pedra porosa deve estar localizada em relação ao reservatório é de $9 \mathrm{~m}$ (90 kPa de sucção), pois a partir desse 
valor, o sistema pode cavitar ${ }^{3}$. Em decorrência da limitação do pé direito do ambiente ou sala na qual o sistema está instalado, é comum que a sucção máxima imposta seja restrita à $30 \mathrm{kPa}$ (diferença de cotas de, aproximadamente, $3 \mathrm{~m}$ de coluna d'água).

\section{$\underline{\text { Placa de pressão }}$}

O método da placa de pressão se baseia em um dispositivo, o qual é composto por um cilindro de latão, apresentando base de mesmo material com uma pedra porosa circular acoplada ao seu centro, formando uma câmara. Tal pedra deve possuir entrada de ar elevada, geralmente possuindo em torno de $500 \mathrm{kPa}$. A câmara é um requisito para a aplicação da técnica de translação de eixos, desenvolvida por Hilf4, 1956 apud $\mathrm{Ng}$ e Menzies, 2007, com o intuito de se atingirem medições de sucção acima da pressão atmosférica (100 kPa) e evitar-se a cavitação do sistema.

Basicamente, a amostra de solo é conectada ao ambiente externo através da pedra porosa. Aplicando-se uma pressão no interior da câmara (sucção desejada), a pedra tende a perder água e, assim, induz a drenagem da água do corpo de prova (CP), a qual tende a sair pelo tubo de drenagem. Isso faz com que o valor da diferença entre a pressão de ar e água ( $\left.u_{a}-u_{w}\right)$ aumente, até que o sistema fique em equilíbrio com tal pressão imposta (RIDLEY e RAY, 1995; OLIVEIRA, 2004). A máxima sucção imposta é equivalente ao valor de entrada de ar da pedra porosa, de tal forma a deixá-la constantemente saturada.

É crucial que o ambiente interno da câmara esteja completamente vedado de forma a suportar elevada pressão de ar. Tal pressão é proveniente de um compressor de ar, ligado a um regulador de pressão, a um manômetro e à tampa. A base deve ser composta por dois orifícios, um ligado a uma bureta graduada para medição do volume de água drenado e estabilização, enquanto o outro é destinado à circulação de água.

\footnotetext{
${ }^{3}$ A cavitação é o fenômeno de formação de bolhas de ar em um líquido podendo ocorrer através da redução da pressão, aumento de temperatura ou por difusão. Qualquer presença de bolha de ar pode provocar interferência no fluxo de água, seja no instrumento, seja no solo (MARINHO, 1995).

${ }^{4} \mathrm{HILF}, \mathrm{J}$. W. An investigation of pore-water pressure in compacted cohesive soils. Ph.D. thesis, tech. Memo. No. 654. U.S. Department of the Interior, Bureau of Reclamation, Design and Construction Division, Denver, Colorado. 1956.
} 
A Figura 19 apresenta um rascunho do equipamento que aplica a técnica de translação de eixos.

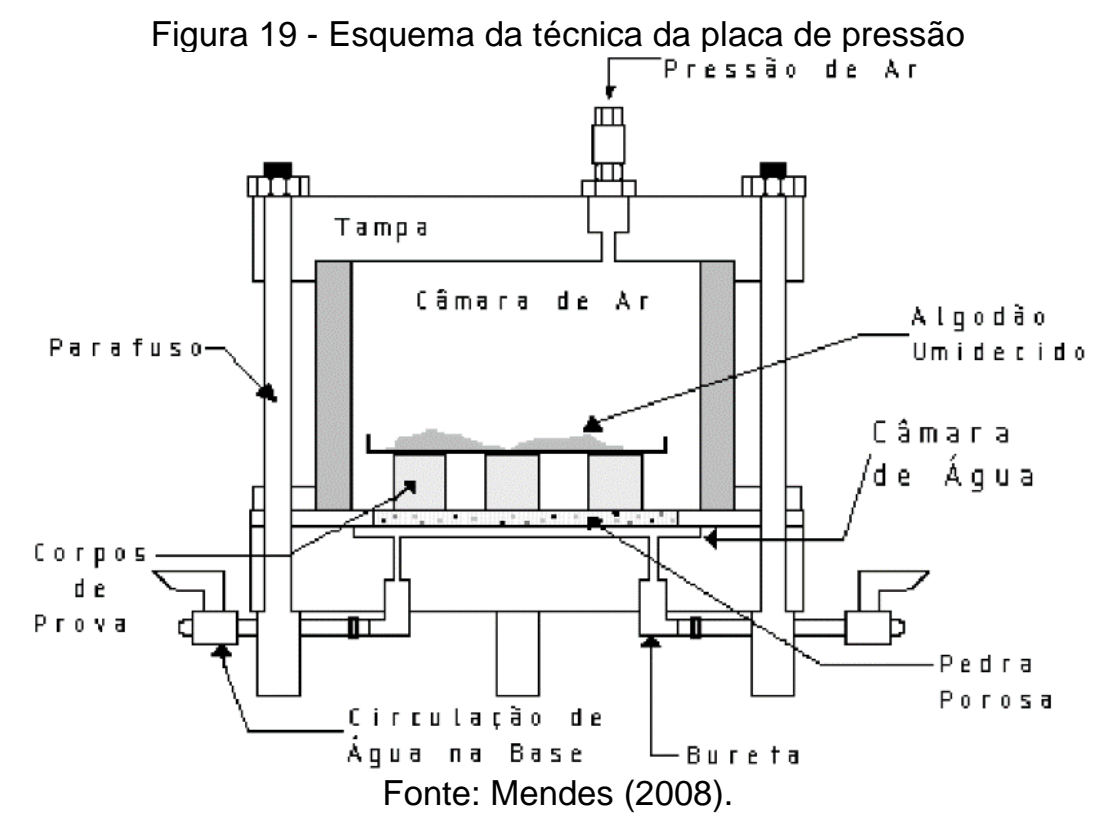

\section{Método do papel filtro}

O ensaio do papel filtro é um método de medição indireta da sucção, pois se supõe que ocorra o equilíbrio entre a umidade do papel filtro e a umidade de uma amostra de solo através da troca de água entre os dois meios pelo princípio de adsorção e equilíbrio (MARINHO, 1995). Além disso, tal técnica é muito utilizada em decorrência da sua facilidade, baixo custo e extensa faixa de medição, apesar da necessidade de cuidado durante sua execução e na interpretação dos seus resultados (MENDES, 2008).

Marinho $(1995,1997)$ relata que o uso do papel filtro é essencial para a medição de sucções elevadas, devido a sua boa capacidade de absorção de umidade (entre 6\% e 175\%) e alcance de sucções (entre 3 kPa e 29000 kPa) para o tipo Whatman n 42.

Além disso, a partir dele, pode-se extrair a sucção matricial ou a sucção total (MARINHO, 1994). Quando o papel está em contato com o corpo de prova (CP) através do fluxo capilar, a sucção matricial é medida. Por outro lado, a sucção total pode ser medida quando o mesmo está separado da estrutura de solo através do fluxo 
de vapor. O fluxo capilar implica em uma interação com o papel filtro sem que a molécula de água perca continuidade, enquanto que o fluxo de vapor ocorre quando moléculas de água escapam da superfície do solo vencendo tanto forças capilares quanto osmóticas (MARINHO, 1994). A Figura 20 mostra um esquema adaptado do método do papel filtro na determinação da sucção total e da sucção matricial.

Figura 20 - Duas configurações do ensaio do papel filtro

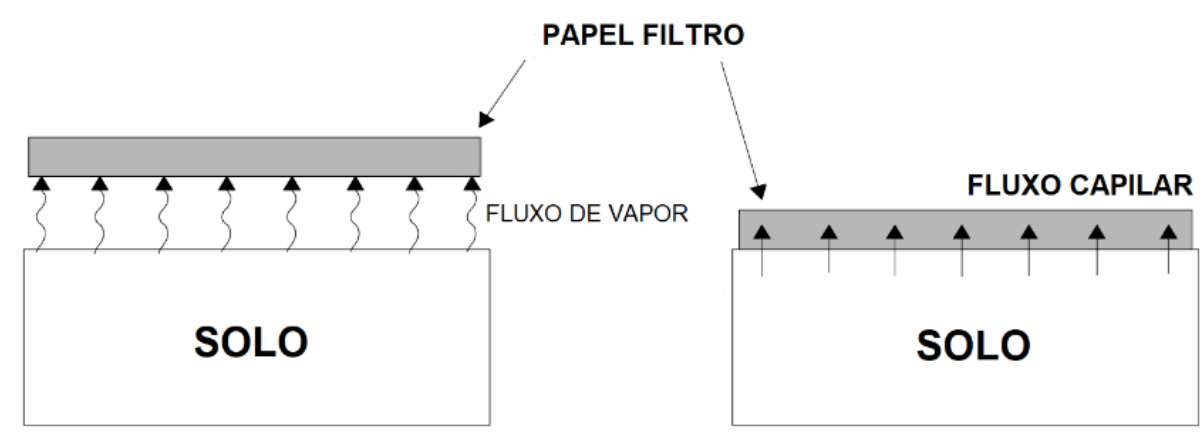

Fonte: adaptado de Marinho (1994).

O tempo de equilíbrio de umidade entre o papel filtro e o solo é um ponto importante a ser tratado. Segundo Marinho (1995), o tempo máximo de 7 dias é o suficiente para a estabilização ou equilíbrio de fluxo de um meio para o outro na determinação da sucção matricial. Por outro lado, o tempo de equilíbrio para a determinação da sucção total pelo papel filtro depende do nível de sucção, como mostra a Tabela 2.

Tabela 2 - Tempo de equilíbrio para o método do papel filtro na determinação da sucção total

\begin{tabular}{cc} 
Nível de sucção $(\mathrm{kPa})$ & Tempo de equilíbrio (dias) \\
\hline $0-100$ & Indeterminado $(<30)$ \\
\hline $100-250$ & 30 \\
\hline $250-1000$ & 15 \\
\hline$>1000$ & 7 \\
\hline \multicolumn{2}{c}{ Fonte: Marinho (1994). }
\end{tabular}

Os dois tipos de papéis filtro mais comumente utilizados são: Whatman ㄲo 42 e o Scheicher \& Schell no 589 (FREDLUND e RAHARDJO, 1993; MARINHO, 1997). A correspondência entre o valor de sucção a ser determinada e o respectivo teor de umidade do papel é feita a partir de uma curva de calibração específica para cada tipo de papel utilizado, como explica a norma ASTM D5298 (2016). 
Diversas curvas de calibração foram determinadas por pesquisadores e publicadas na literatura, as quais podem ser encontradas em Marinho (1994). Dentre as curvas de calibração definida para o papel filtro Whatman $n^{\circ} 42$, pode-se destacar a curva obtida por Oliveira (2004), representada pelas Equações 11 e 12:

- para umidades do papel filtro $<30 \%$ :

$$
\psi(k P a)=10^{(7,91-3,8 w)}
$$

- para umidades do papel filtro $>30 \%$ :

$$
\psi(k P a)=10^{(5,75-2,34 w)}
$$

Onde:

$\psi$ - sucção matricial;

$w$ - umidade gravimétrica do papel filtro.

\section{Sensores de sucção matricial (blocos porosos)}

Dentre os sensores para medição da sucção matricial do solo existentes, podem ser citados nesse trabalho o sensor de matriz granular (GMS 200SS), desenvolvido pela IRROMETER Company, e o sensor TEROS-21, desenvolvido pela METER Group.

Os sensores GMS 200SS e TEROS-21 operam de forma similar ao bloco poroso de gesso, com base no princípio da condutividade elétrica e permissividade dielétrica (SHOCK et al., 1998; MENDES, 2008; ALMEIDA, 2011; FREDLUND e RAHARDJO, 2012). Inicialmente desenvolvidos para a área agronômica na medição da sucção matricial e umidade do solo em processos de irrigação, apresentam algumas vantagens quando comparados aos demais instrumentos de medição de sucção do solo em campo. 
Dentre as suas vantagens, se podem citar: baixo custo, isenção de manutenção, facilidade de operação, resistência à salinidade presente no solo e elevada faixa de medição, 0 a -200 kPa, para o GMS 200SS, -9 a -100.000 kPa, para o TEROS-21.

Os sensores GMS 200SS possuem eletrodos envolvidos por uma matriz granular (areia quartzosa e gesso comprimidos), enquanto os sensores TEROS-21 possuem eletrodos envolvidos por duas pedras porosas (Figura 21).

Figura 21 - Sensores de medição de potencial matricial:

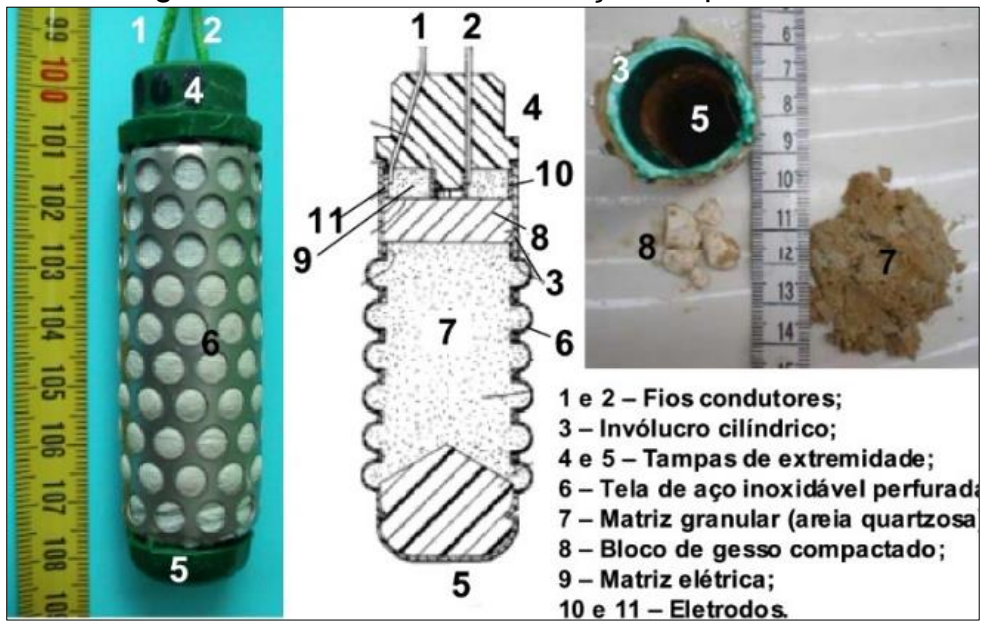

(a)

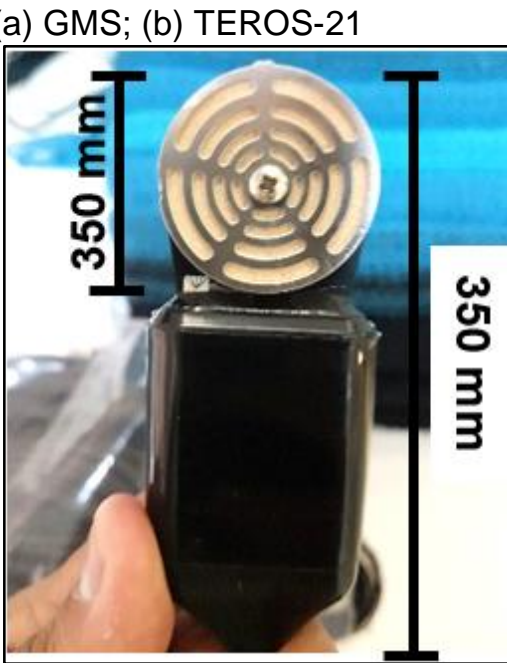

(b)

Fonte: (a) Mendes (2008).

Vale ressaltar que, para a conversão dos valores de resistência elétrica e permissividade dielétrica em tensão de sucção, ambos os sensores possuem sua própria calibração, baseada na curva característica da sua respectiva matriz porosa.

Com relação ao sensor GMS 200SS, a calibração de fábrica foi realizada para um solo específico sendo necessária calibração adicional em campo e/ou em laboratório para outro tipo de solo utilizado (THOMPSON et al., 2006; GANJEGUNTE et al., 2012). A calibração utilizada para os sensores fabricados mais recentemente foi proposta por Shock et al. (1998), representada pela Equação 13 e Figura 22.

$$
P=\frac{(-3,213) * R-4,093)}{\left(1-0,009733 * R-0,01205 * T_{s}\right)}
$$


Onde:

$P$ - sucção matricial aferida pelo sensor;

$R$ - resistência elétrica ou facilidade de circular corrente elétrica;

$T_{s}$ - temperatura do solo.

Figura 22 - Calibração Watermark 200SS "Resistência elétrica do sensor versus sucção"

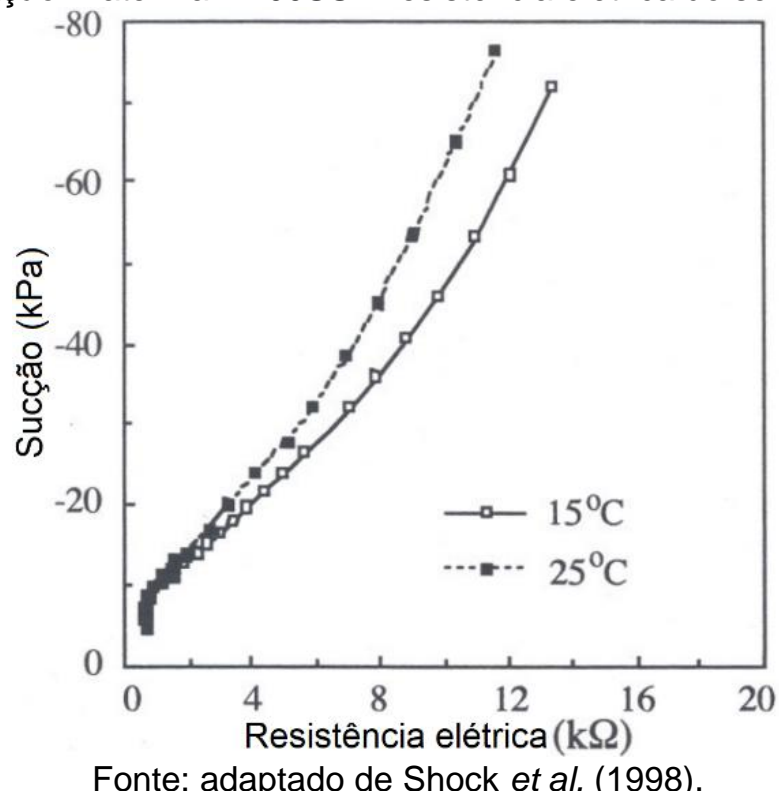

A Equação (13) compreende uma calibração obtida para um intervalo de 10 a $80 \mathrm{kPa}$. Para valores abaixo de $10 \mathrm{kPa}$ e acima de $80 \mathrm{kPa}$, extrapolações lineares típicas são utilizadas na literatura. O manual do fabricante ressalta que os valores de sucção variam em função da temperatura do solo, e no caso de falta de dados de temperatura do solo, uma temperatura padrão de $24^{\circ} \mathrm{C}$ deve ser admitida.

A calibração de uso do TEROS-21, se baseia na umidade de dois discos porosos e os seus respectivos valores de sucção matricial através das suas curvas características, para uma determinada permissividade dielétrica. Tais discos foram dimensionados, de tal forma que o valor da entrada de ar estivesse compreendido em um intervalo considerável, possibilitando a sua aplicação para solos com diferentes capacidades de retenção (TEROS-21 Manual, 2018).

Com base nisso, a pedra porosa só irá perder água ou drenar, se o solo em contato alcançar o seu respectivo valor de entrada de ar. Além disso, é possível determinarse a temperatura do solo através de termistores que variam em função da sua 
resistência elétrica. Flutuações da temperatura pode afetar a capacidade de leitura para sucções matriciais inferiores à $500 \mathrm{kPa}$ (TEROS-21 Manual, 2018). A Figura 23 mostra o gráfico da curva característica da pedra porosa, determinada e obtida no manual do fabricante.

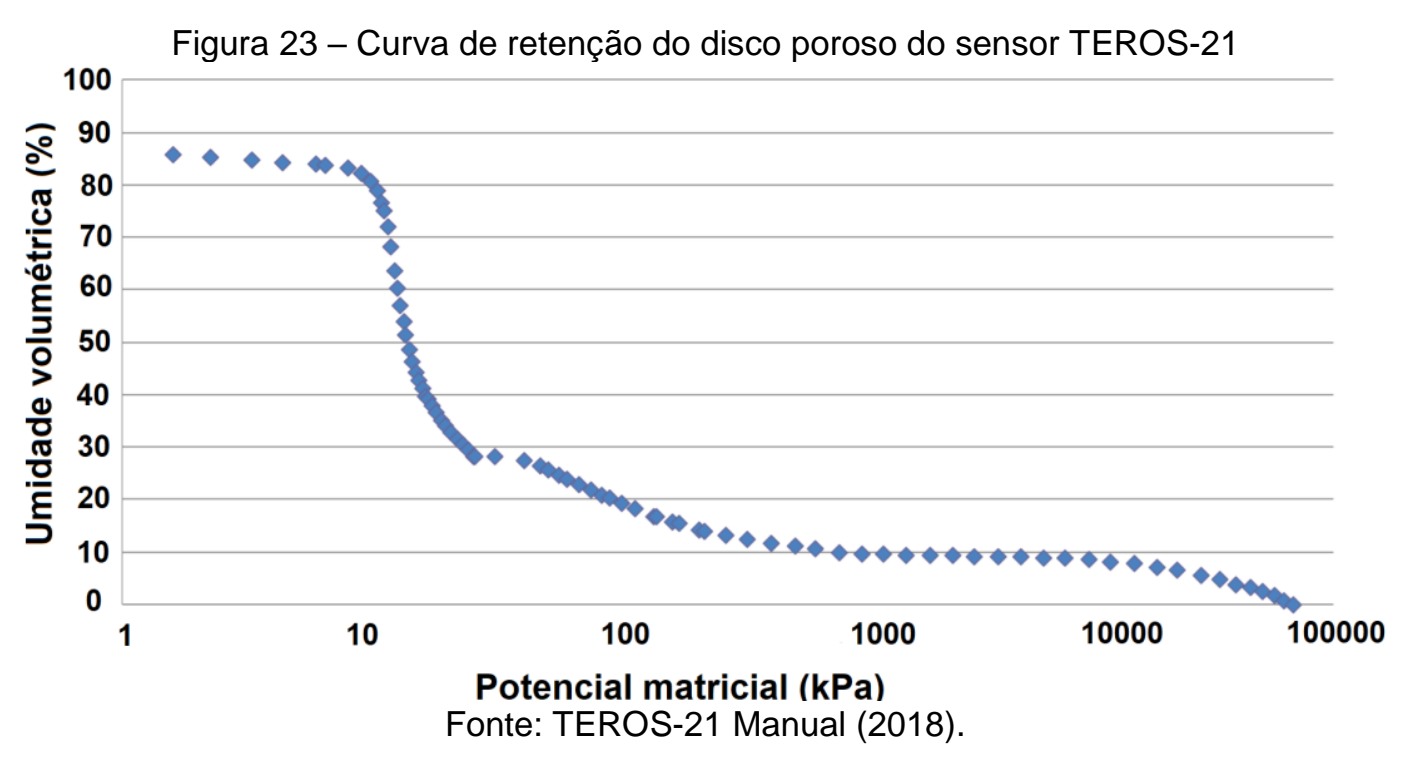

\subsection{5 - Fluxo isotérmico de água nos solos}

Sabe-se que o fluxo de água através dos poros do solo é oriundo da diferença de pressão entre dois pontos do meio poroso, um com mais energia (maior teor de umidade) e o outro menos (menor teor de umidade). Tal dinâmica pode ocorrer após eventos chuvosos, processos de irrigação, ou seja, a partir de qualquer acúmulo de uma lâmina d'água sobre a superfície do solo ("poças").

Além da quantidade de água disponível, a infiltração depende de outros fatores: tipo de solo, umidade inicial do solo, declividade do terreno, intensidade e duração da chuva ou irrigação e da temperatura (que está associada à viscosidade e peso específico do fluido). Segundo Fredlund e Rahardjo (1993), o fluxo de água ou infiltração no interior do solo pode ser dividido em dois tipos: saturado e não saturado.

\section{Fluxo de água em solos saturados}

O fluxo saturado na Mecânica dos Solos Clássica é governado pela equação de Bernoulli para um fluxo permanente de um fluido não viscoso, incompressível e de 
densidade constante e um tubo de água corrente (AZEVEDO NETO, 1998). Tal fluxo corresponde a soma de três tipos de energia: altimétrica, piezométrica e cinética, explicitadas em ordem pela Equação (14) (FREDLUND e RAHARDJO, 1993; PINTO, 2006).

$$
h=z+\frac{u}{\rho_{w}}+\frac{V^{2}}{2 g}
$$

Onde:

$h$ - carga hidráulica total;

$z$ - cota altimétrica de um ponto;

$u$ - pressão da água nos poros (piezométrica) num ponto qualquer;

$\rho_{w}$ - massa específica da água;

$V$ - velocidade de percolação intersticial em um ponto;

$g$ - aceleração da gravidade.

Considerando-se que a carga cinética é desprezível em comparação à carga altimétrica e piezométrica, a energia total no solo pode ser representada pela Equação (15).

$$
h=z+\frac{\mu}{\rho_{w}}
$$

Darcy postulou em 1856 a lei que governa e quantifica o fluxo de água no solo saturado, ressaltando que a densidade de fluxo é proporcional ao gradiente hidráulico na direção vertical (Equação 16). O sinal negativo na Equação (16) está relacionado ao sentido do fluxo, que ocorre no sentido inverso ao seu gradiente, ou seja, de pontos com maior potencial para pontos com menor potencial.

$$
v_{w}=\frac{q}{A}=-k_{w} * \frac{\varphi H}{\varphi z}
$$


Onde:

$\mathrm{v}_{w}$ - velocidade da água;

$q$ - densidade de fluxo;

$A$ - área da secção transversal por onde ocorre o fluxo;

$k_{w}$ - coeficiente de permeabilidade para a fase da água;

$\frac{\varphi H}{\varphi z}$ - gradiente hidráulico na direção vertical.

\section{Fluxo de água em solos não saturados}

Segundo Fredlund e Rahardjo (1993), para que a lei de Darcy, apresentada pela Equação (17), fosse válida para o fluxo de água em solos não saturados (RICHARDS, 1931), a condutividade hidráulica não saturada do solo não pode ser adotada como constante, mas sim função do teor de umidade volumétrico do solo e consequentemente da sucção matricial.

$$
q=-k(\theta) * \frac{\varphi h}{\varphi z}
$$

Onde:

$q$ - densidade de fluxo;

$k(\theta)$ - condutividade hidráulica em função do grau de saturação, para os solos não saturados.

O princípio da conservação de massa (Equação 18) estabelece que, para um dado volume elementar de solo, a taxa de água que é perdida ou ganha é conservada e igual ao fluxo efetivo de entrada e saída. Tal princípio, conhecido também por lei da continuidade, surgiu com o intuito de se determinar o fluxo em solos não saturados em várias direções, sob condições isotérmicas, variando-se em função do tempo e do espaço como resultado de dois mecanismos: (i) variações climáticas; e (ii) capacidade de retenção de água no solo (Figura 24) (LU e LIKOS, 2004).

$$
\frac{\varphi\left(\rho_{w} \theta\right)}{\varphi t}=-\rho_{w}\left(\frac{\varphi q_{x}}{\varphi x}+\frac{\varphi q_{y}}{\varphi y}+\frac{\varphi q_{z}}{\varphi z}\right)
$$


Onde:

$\frac{\varphi \theta}{\varphi t}$ - teor de umidade volumétrica por unidade de tempo;

$q_{x}$ - fluxo na direção x;

$q_{y}$ - fluxo na direção y;

$q_{z}$ - fluxo na direção z;

$\rho_{w}$ - massa específica da água.

Figura 24 - Elemento de volume de solo

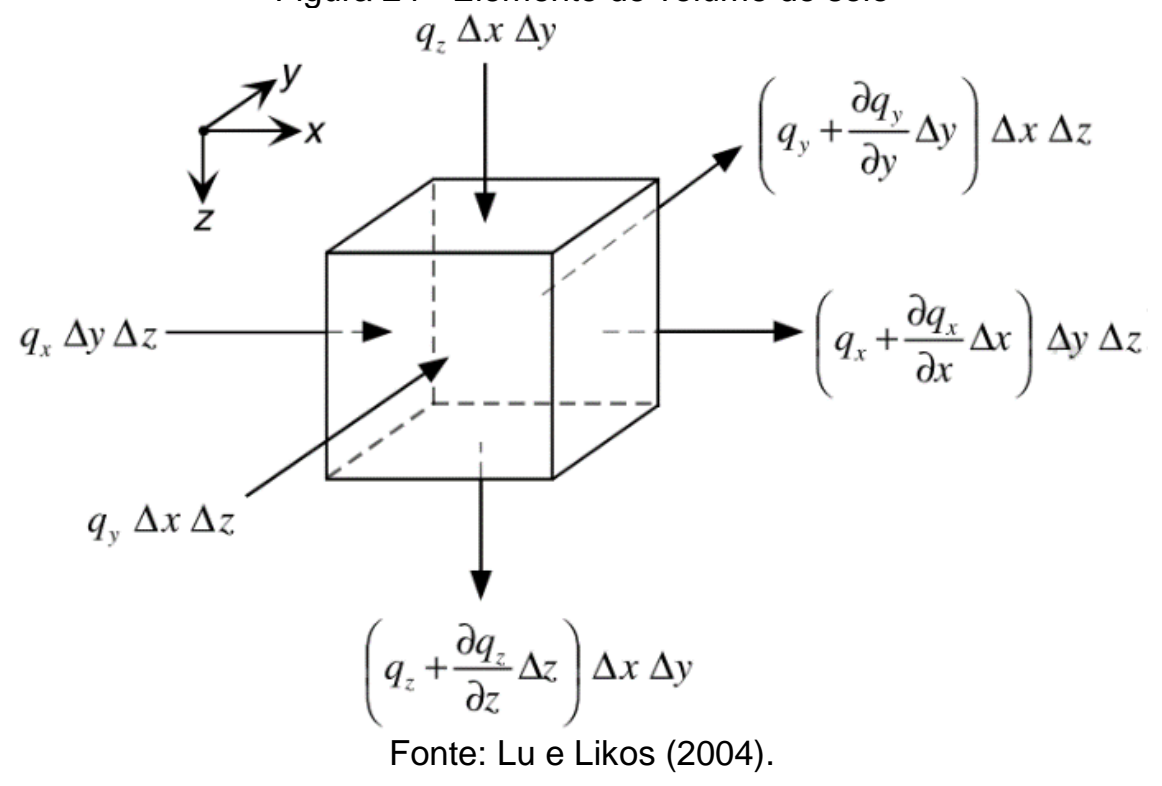

Desse modo, ao substituir-se a Equação (17) na Equação (18), e assumindo-se massa específica da água constante, obtém-se a equação de Richards (1931), que governa o fluxo não saturado em mais de uma direção (2D/3D) (Equação 19).

$$
k_{x} \frac{\partial^{2} h}{\partial x^{2}}+k_{y} \frac{\partial^{2} h}{\partial y^{2}}+k_{z} \frac{\partial^{2} h}{\partial z^{2}}=\frac{\partial \theta}{\partial t}=m_{w} \rho_{w} \frac{\partial h}{\partial t}
$$

Onde:

$h$ - carga hidráulica total;

$k_{x}, k_{y}$ e $k_{z}$-condutividade hidráulica saturada na direção x, y e z;

$\theta$ - umidade volumétrica;

$\rho_{w}$ - massa específica da água;

$m_{w}$ - coeficiente de variação volumétrica;

$t$ - tempo. 


\section{4 - Clima}

\subsection{1 - Ciclo hidrológico e balanço hídrico}

O ciclo hidrológico pode ser definido como o fenômeno que rege a circulação fechada da água entre dois grupos, tais quais a superfície terrestre, a qual abrange os continentes (litosfera) e oceano (hidrosfera), e a atmosfera, devido às correntes aéreas que se deslocam tanto no estado de vapor, como também no estado líquido e sólido (TUCCI, 2000). É possível começar a descrevê-lo a partir do vapor de água presente na atmosfera, que a partir de condições climáticas específicas, condensa dando origem às precipitações.

A partir das precipitações, a água que atinge o solo segue vários caminhos. Devido ao fato de o solo ser um meio poroso, ocorre infiltração de toda a precipitação que chega ao solo até que a superfície do mesmo não se satura, podendo ser absorvida pelas raízes das plantas e/ou infiltrar no lençol freático que normalmente deságua nos rios e mares. Quando o solo começa a se saturar em profundidade, a água infiltrada começa a diminuir, sendo comandada pelo estado de tensões capilares nos seus poros, que variam em função das condições climáticas locais, e pela gravidade, iniciando o processo de escoamento superficial (Figura 25).

Figura 25 - Principais componentes do ciclo hidrológico

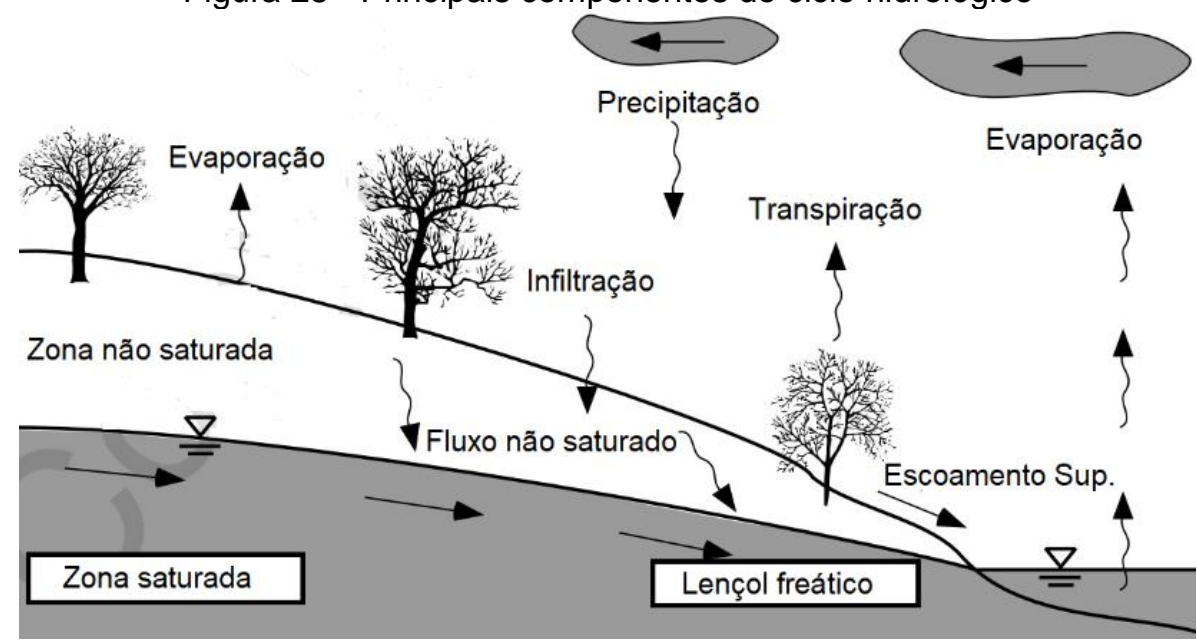

Fonte: adaptado de Lu e Likos (2004).

O escoamento superficial se torna uma pequena rede de drenagem, em decorrência da erosão de partículas de solo causada por pequenos filetes de água em seus 
trajetos aliada à topografia preexistente, que segue em direção a uma rede de cursos de água mais estáveis, formada por rios e oceanos.

Tucci (2000) reforça que a rede de drenagem mais estável é o oceano, o qual em função de uma complexa interação com fatores físicos e meteorológicos, tais como os ventos, rotação da Terra, variação da energia solar absorvida, evapora para a atmosfera, fechando o ciclo hidrológico. Dessa forma, a quantidade de água distribuída em cada uma das partes do ciclo hidrológico, pode ser expressa pela Equação (20) (CHOW, 1959):

$$
I-O=P-E T-R-R_{g}=\Delta S
$$

Onde:

I - Fluxos positivos (entrada de água);

$O$ - Fluxos negativos (saída de água);

$P$ - Precipitação;

ET - Evapotranspiração;

$R_{s r}$ - Descarga fluvial;

$R_{g}$ - Descarga subterrânea;

$\Delta S$ - Água infiltrada no solo.

Percebe-se que, a partir do balanço hídrico, se torna possível quantificar-se a água presente em cada etapa do ciclo hidrológico. A oscilação dos fluxos de umidade e infiltração na interface solo-clima, se dão especificamente pelas características ou condições climáticas da região tais como a temperatura, a intensidade e frequência de eventos pluviométricos, índices de evapotranspiração e umidade.

\subsection{2 - Fatores climáticos}

O clima, conjunto de todos os estados da atmosfera numa dada região ao longo dos anos durante um longo intervalo de tempo, é influenciado e caracterizado por elementos denominados fatores climáticos, os quais impactam a temperatura, umidade, pluviosidade, etc. (CHOW, 1959; SANT'ANNA-NETO, 2003). Dentre eles, 
podem ser citados a latitude, altitude, relevo, continentalidade, maritimidade, vegetação, massas de ar e urbanização. A Figura 26 mostra a variação da precipitação média anual no globo terrestre em função do fator latitude.

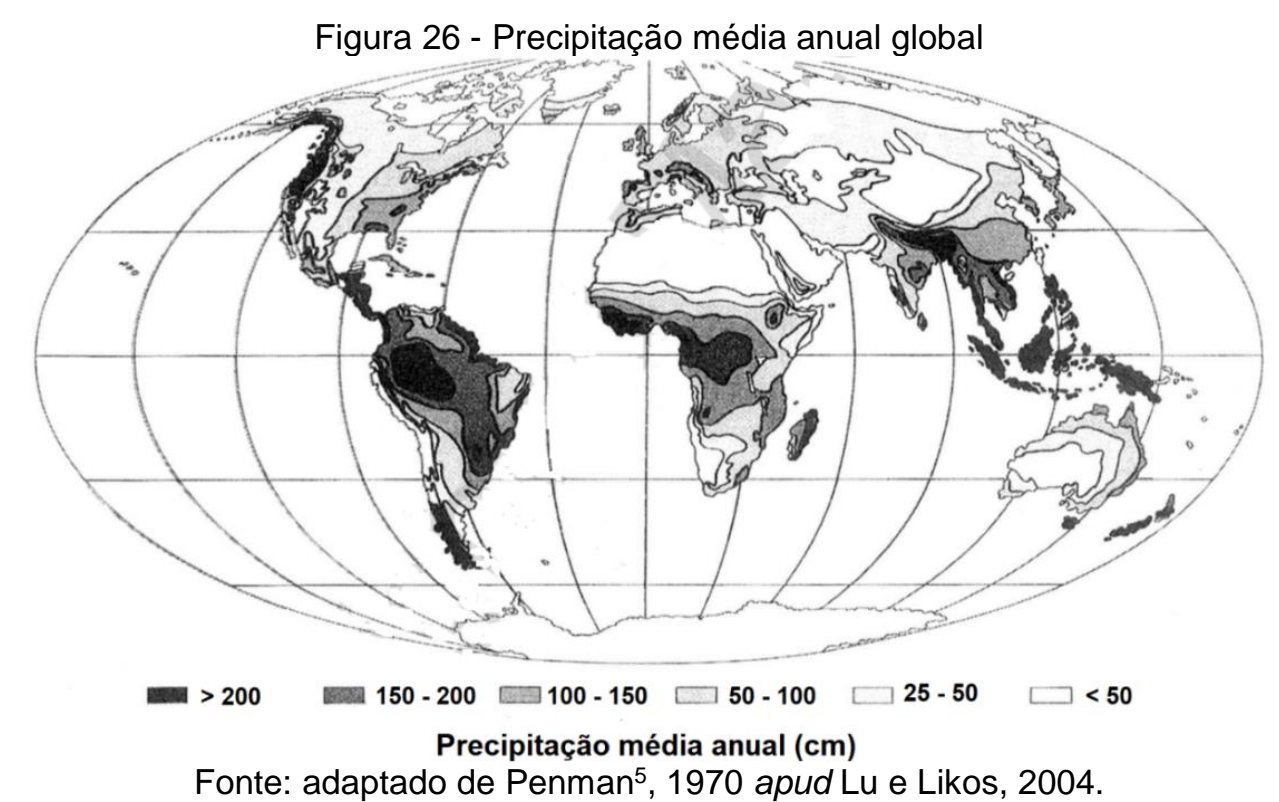

De acordo com a Figura 26, os índices pluviométricos permanecem sempre elevados nas proximidades da linha do Equador, onde as radiações solares incidem de forma mais direta. À medida que ocorrem variações da latitude, as temperaturas diminuem e, dessa forma, menores serão os índices de aquecimento, umidade, precipitação e infiltração ocorrentes na interface solo-clima (CHOW, 1959). Além disso, a evaporação também varia na superfície terrestre, a qual depende da intensidade de radiação solar, do baixo teor de umidade relativa do ar e da disponibilidade de água.

O Brasil, localizado entre 0 e 40 graus de latitude na direção sul, possui precipitações superiores às evaporações (PEIXOTO e KETTANI, 1973). Classificado pelos climas equatorial, tropical e temperado, possui grande variabilidade dos fatores climáticos como relevo, latitude, altitude, massas de ar e correntes marítimas as quais está sujeito. A partir dos mapas dos dados históricos mensais de precipitação, temperatura e evaporação no Brasil de 1981 a 2010 (INMET, 2018), se pode observar a diferença do clima entre o primeiro e o segundo semestre. Na Figura 27, merece destaque o

5 PENMAN, H. L. The water cycle. Scientific American, 233(3), 54-33, 1970. 
estado de São Paulo, com a sigla "SP", localizado na região sudeste e considerado o local de estudo deste trabalho.

Figura 27 - Precipitação total (a), evaporação (b) e temperatura (c) médias mensais de 1981 a 2010
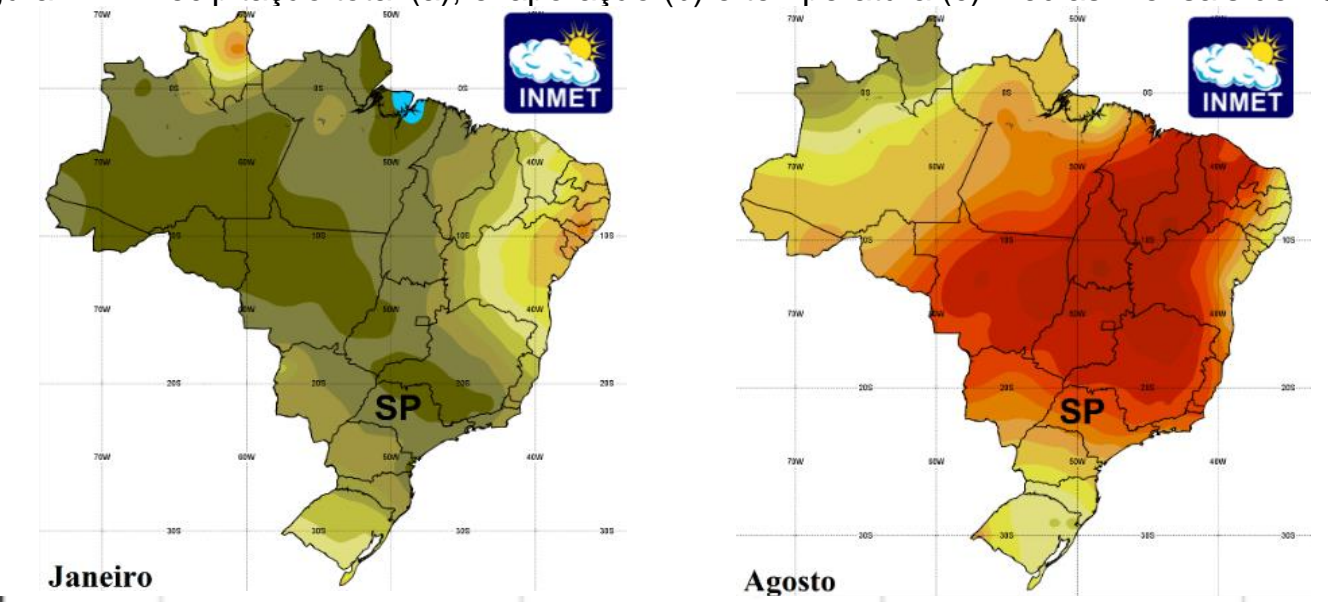

(a)
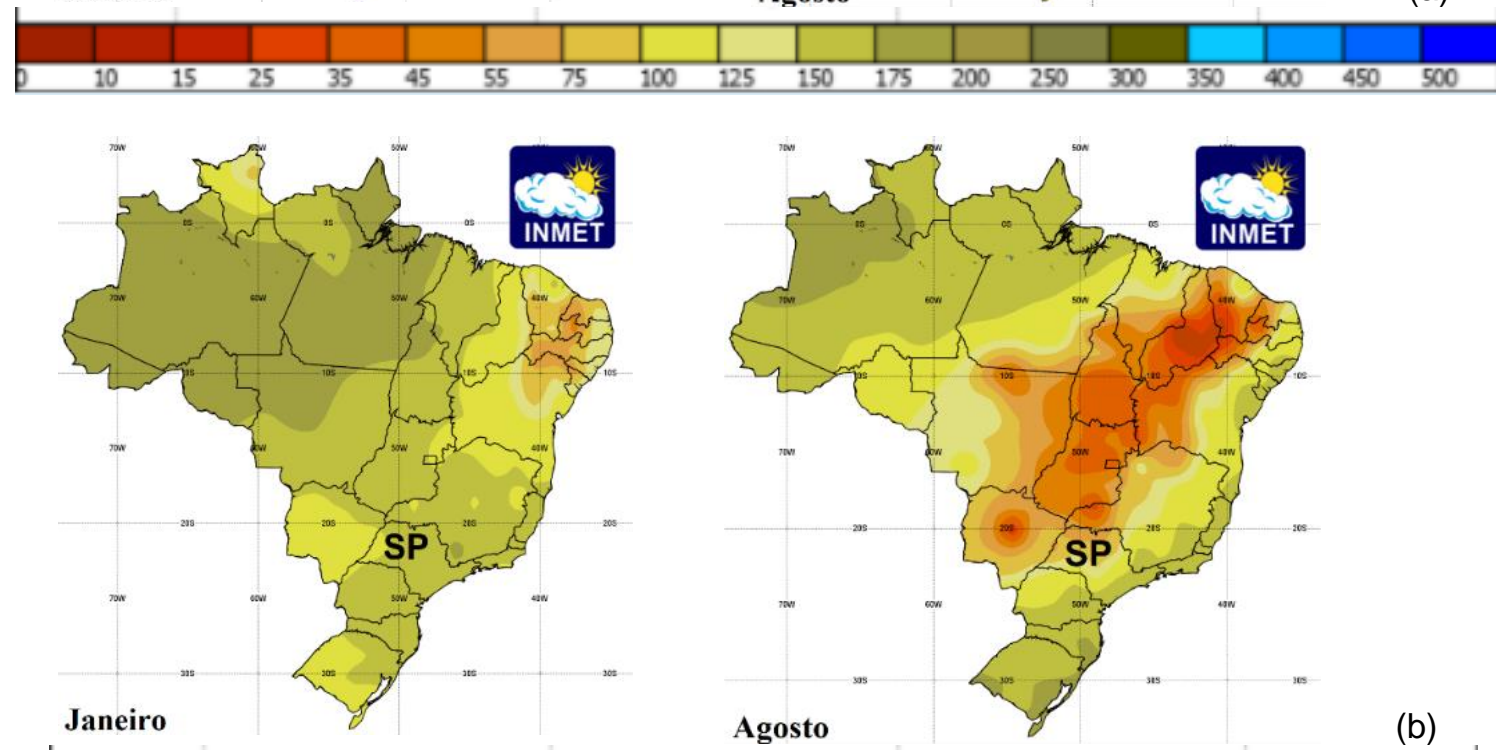

\begin{tabular}{|l|l|l|l|l|l|l|l|l|l|l|l|l|l|}
\hline 10 & 50 & 100 & & & & & & & & & & & \\
\hline
\end{tabular}

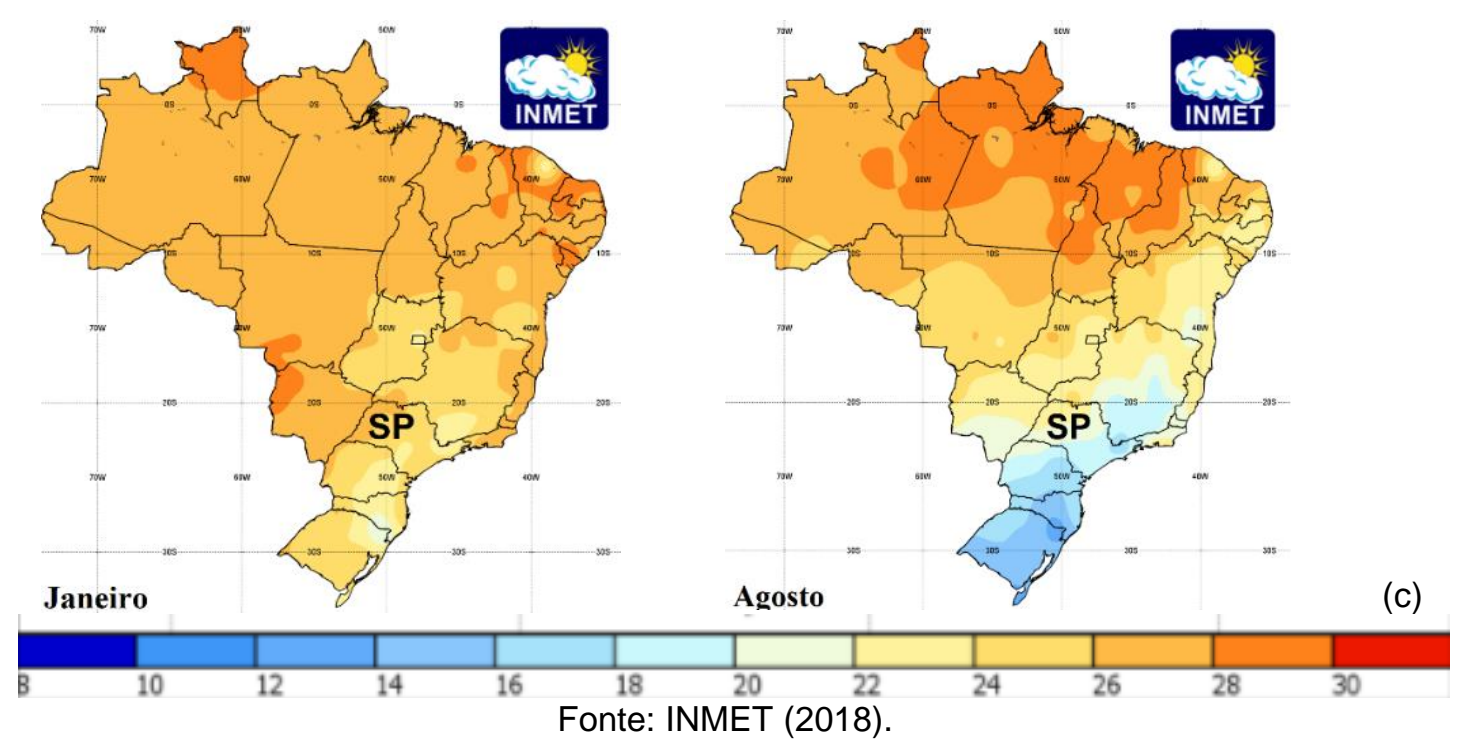




\subsection{3 - Interação ferrovia-clima}

Em geral, os solos de subleito de pavimentos estão situados na zona vadosa ou não saturada (acima do lençol freático), assim como a maioria das estruturas de engenharia projetadas com solos compactados, sendo bastante sensível às condições climáticas locais.

Lu e Likos (2004) explicam que a variação da umidade e da sucção do solo em função do clima é uma característica singular dos solos não saturados. A Figura 28 mostra o esquema dessa interação solo-clima.

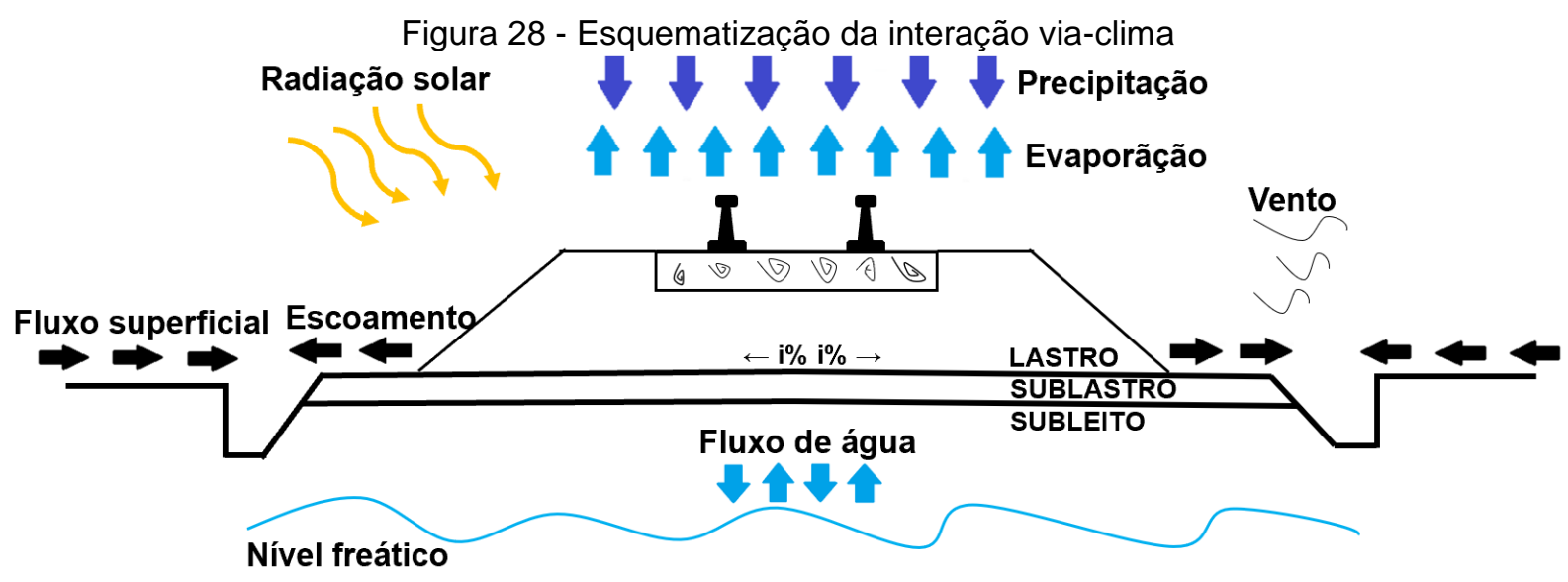

Para Fredlund e Rahardjo (1993), as condições climáticas são os principais fatores responsáveis pela condição não saturada do solo. Segundo os mesmos autores, a água é removida do mesmo através da evapotranspiração, através do fluxo ascendente, e inserida por fluxo descendente pelas precipitações, ambos fatores do ciclo hidrológico. O primeiro tende a ocasionar trincas, relacionadas a retração do solo (secagem) e a segunda tende a saturar o meio particulado.

Todos os anos, aterros compactados estão submetidos a variações das condições climáticas. Essas variações provocam comportamentos de contração e expansão no solo em função da variação da distribuição da pressão neutra ou poropressão. Dessa forma, pode-se dizer que a distribuição da poropressão adquire diversas configurações ao longo da profundidade (FREDLUND e RAHARDJO, 1993). 
Segundo Fredlund e Rahardjo (1993), variações das condições climáticas influenciam significativamente as proximidades da superfície do solo. Em climas áridos e semiáridos, que possuem taxas de evaporação superiores à taxa de precipitação além de baixos níveis freáticos, contrações e trincas no solo ocorrem. Esse fenômeno é causado quando a poropressão negativa ou tensão de sucção nos poros em todas as direções, excede a tensão de confinamento a que o solo está submetido.

Em climas tropicais e subtropicais, nos quais a precipitação excede a evaporação, o encharcamento do solo ou aumento da poropressão gera além da expansão, uma perda significativa da resistência ao cisalhamento, que está ligada ao módulo de resiliência e capacidade de suporte (FREDLUND e RAHARDJO, 1993), dois parâmetros cruciais na pavimentação. A Figura 29 mostra o perfil de umidade e sucção em função dos fenômenos climáticos.

Figura 29 - Influência do clima nos estados de tensões do solo de um subleito ferroviário EVAPOTRANSPIRAÇÃO

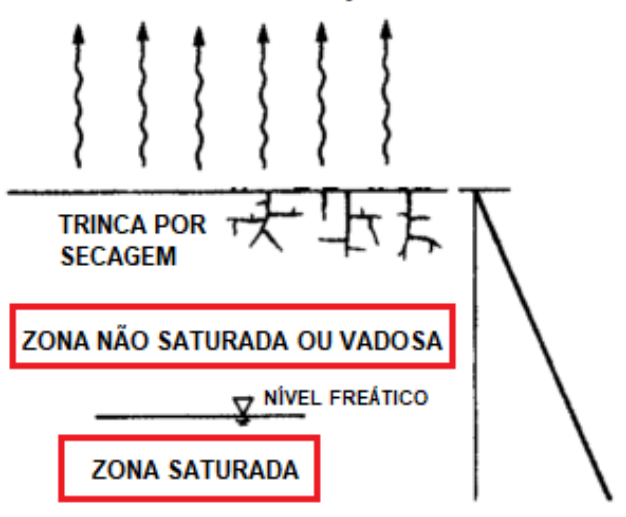

TENSÃO TOTAL

$(\sigma)$

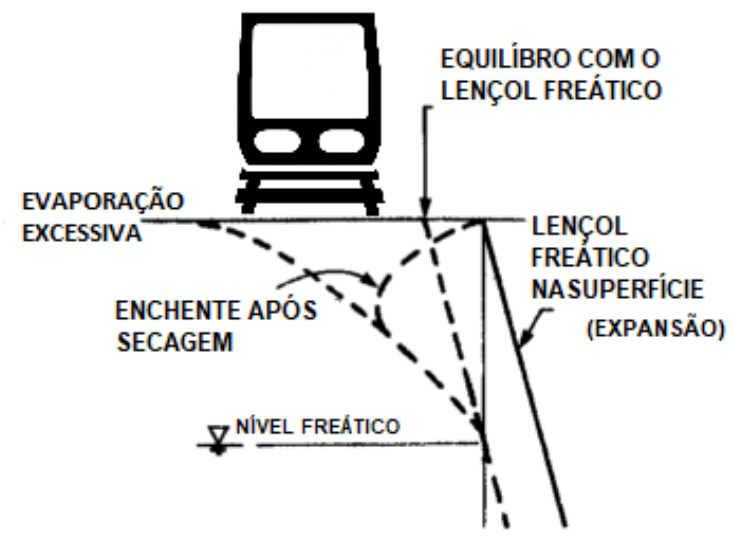

PRESSÃO DO AR

$\left(u_{a}\right)$
PRESSÃO DA ÁGUA

$\left(u_{w}\right)$

Fonte: adaptado de Fredlund e Rahardjo (1993)

\section{5 - Módulo de resiliência versus sucção}

Dentre os fatores os quais influenciam no comportamento resiliente de solos podem ser citados: a carga ou duração da carga, frequência de aplicação da carga, tamanho dos grãos, níveis de tensões e grau de saturação ou umidade (LOTTMAN, 1976; LI e SELIG, 1994). Como este último está constitutivamente relacionado com a tensão de sucção, diversos estudos vieram à tona com o intuito de entender a influência da sucção no módulo de resiliência $\left(\mathrm{Mr}_{\mathrm{r}}\right)$. 
Sabe-se que a variação da umidade de materiais de solo na pavimentação depende diretamente das condições climáticas da região que foram aplicados, das suas características hidráulicas e das condições de drenagem locais. Por outro lado, a mecânica dos solos não saturados explica que a variação sazonal da umidade no solo altera o seu estado de tensões, devido à variação da sucção matricial. Portanto, a forma mais racional para a avaliação do efeito da variação das condições climáticas no módulo de resiliência é a consideração da sucção como variável determinante do estado de tensões do solo de subleito, considerando que somente a umidade não é capaz de explicar o seu comportamento não saturado.

Por isso, vários pesquisadores têm avaliado o comportamento de solos compactados em termos de sucção matricial, tais como Fredlund et al. (1975), Edil e Motan (1979), Rodrigues (1997), Phillip (1996), Yang et al. (2008), Ng et al. (2012) e Han e Vanapalli (2016). Edil e Motan (1979) identificaram e quantificaram em laboratório o efeito da umidade (Wot $\pm 2 \%$ ) de dois tipos de solo de subleito, em termos de sucção, nas características resilientes e de resistência sob condições típicas de carga em pavimento rodoviário. Os autores verificaram um crescimento do módulo de resiliência para valores de sucção entre $100 \mathrm{kPa}$ até a sucção crítica $(800 \mathrm{kPa})$, sendo que a partir desta o módulo de resiliência decresce, provavelmente devido a redução da umidade e, consequentemente, da atuação da sucção no esqueleto do solo (Figura 30).

Figura 30 - Módulo de resiliência versus sucção do solo
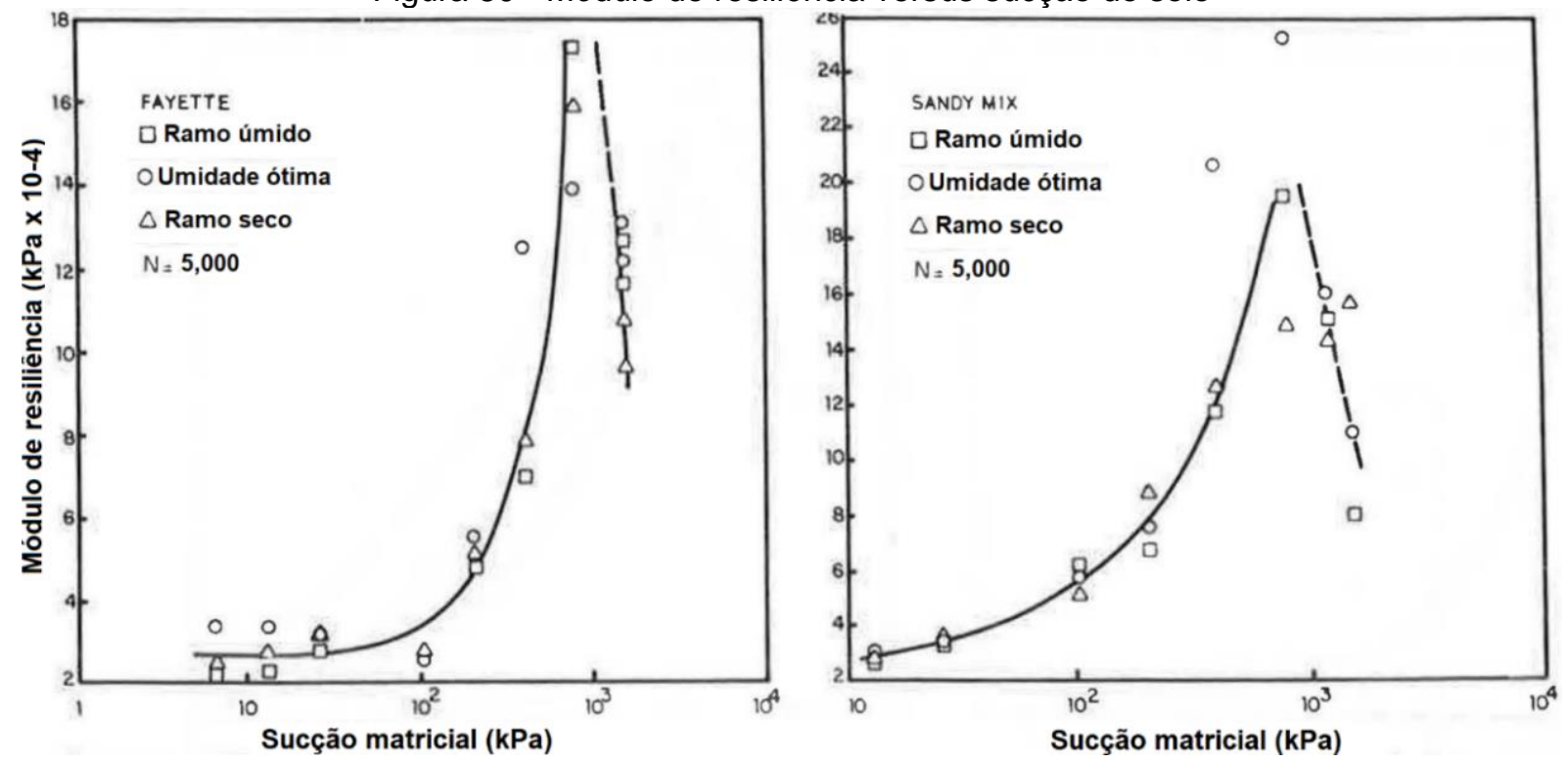

Fonte: adaptado de Edil e Motan (1979). 
Rodrigues (1997) avaliou a influência da sucção no módulo de resiliência de quatro solos com diferentes características geotécnicas comumente utilizados em subleito de pavimentos rodoviários. Para tanto foram realizados ensaios triaxiais de cargas cíclicas em laboratório nas condições Wot, Wot $-2 \%$ (secagem), Wot $+2 \%$ (umedecimento) e secagem e umedecimento, utilizado o método do papel filtro para medição de sucção após o ensaio (Figuras 31 e 32).

Figura 31 - Módulo de resiliência versus sucção do solo

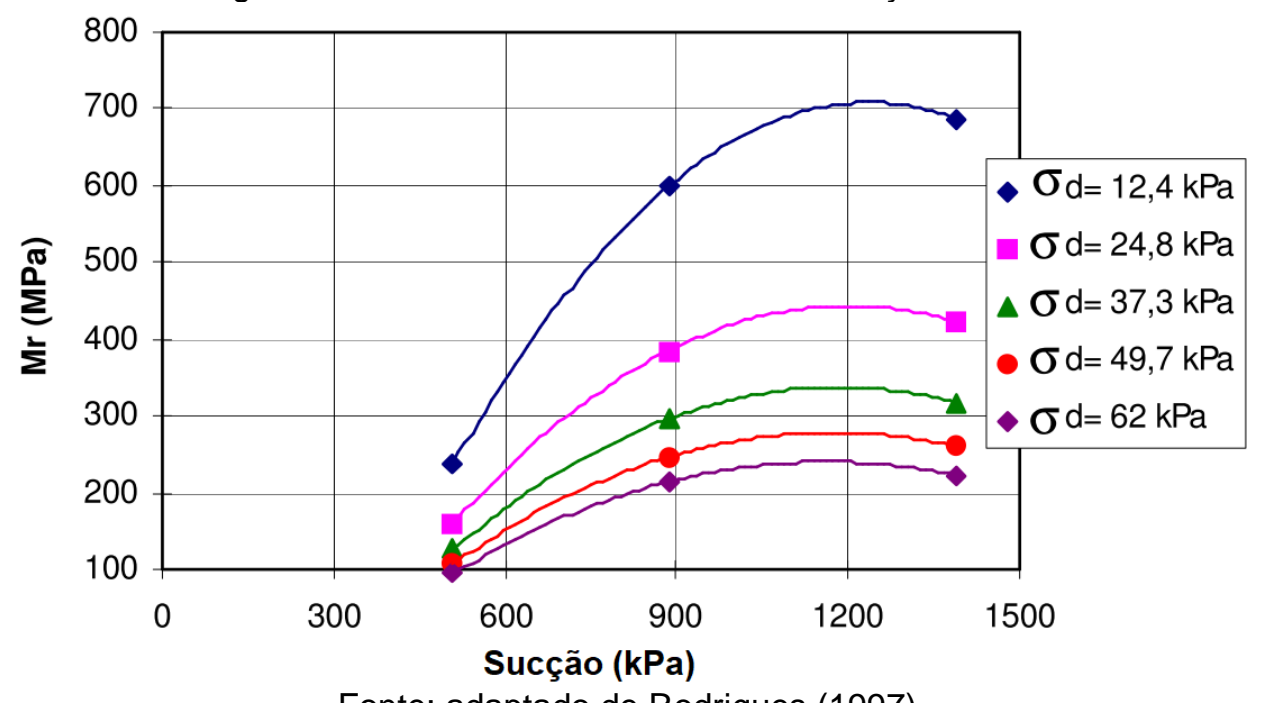

Fonte: adaptado de Rodrigues (1997).

Figura 32 - Módulo de resiliência versus tensão desvio por processo de secagem e de secagemumedecimento

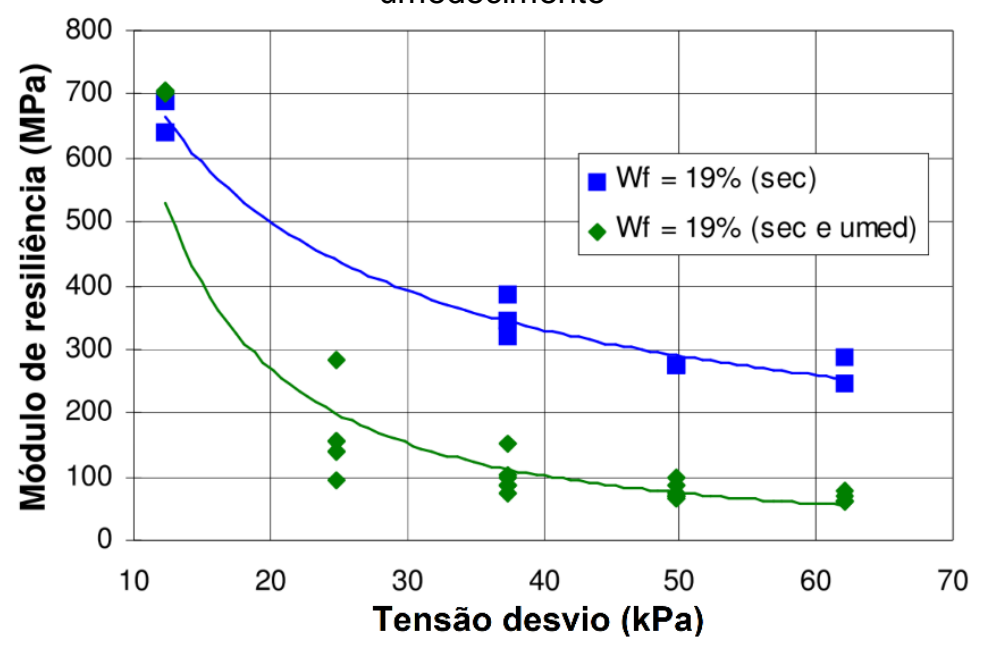

Fonte: adaptado de Rodrigues (1997).

Assim como Edil e Motan (1979), o autor observou que o aumento da sucção provoca um incremento no valor do módulo de resiliência até atingir um valor máximo, a partir do qual o módulo decresce ou permanece constante para qualquer valor de tensão desvio. Além disso, o autor verificou que o solo secando e umedecendo possui maior 
módulo de resiliência, quando comparado com a trajetória de secagem somente, em decorrência da histerese.

Phillip (1996) investigou a relação entre o módulo de resiliência e a sucção total para um solo expansivo de subleito. Verificou-se pelo autor um aumento do módulo de resiliência em função do aumento da tensão de sucção até um valor máximo a partir do qual a sução tende a se tornar constante. Isso foi verificado durante ensaios com variação da tensão desvio e tensão de confinamento constante (Figura 33).

Figura 33 - Variação do módulo de resiliência de solo rígido com a sucção e tensão desvio (para tensão de confinamento de $10 \mathrm{kPa}$ )

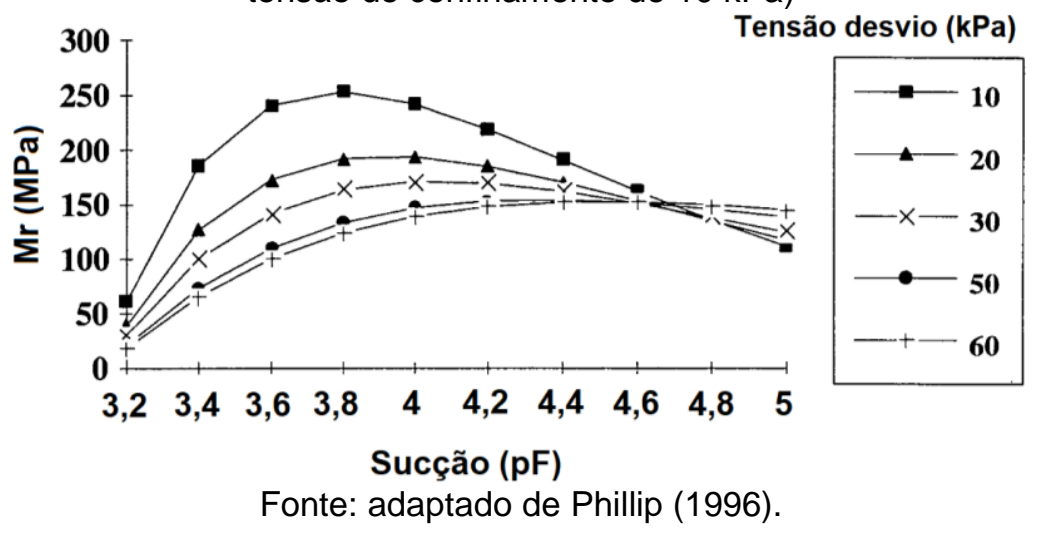

Segundo Fredlund et al. (1975), Vanapalli et al. (1999), Yang et al. (2008) e Ng et al. (2012), a tensão aplicada ( $\sigma_{3}$ e $\sigma_{1}$ ) nos corpos de prova durante o ensaio de módulo de resiliência influencia o valor da sucção $\left(u_{a}-u_{w}\right)$. Isso ocorre devido a alteração da microestrutura e variação da capacidade de retenção do solo. Apesar disso, a medição da sucção através do papel filtro ou sua dedução a partir da curva característica do solo após o ensaio triaxial de carga é bastante utilizada, devido à abordagem não saturada dos solos, simplicidade e baixo custo (YANG et al. 2005).

\section{6 - Modelagem numérica de fluxo não saturado em meio poroso}

A modelagem numérica realizada neste trabalho foi feita por meio do software SEEPW, desenvolvido pela GeoSlope International Ltd. A escolha desse programa ocorreu devido a: (i) possibilidade de análises e verificação de gráficos representativos de frentes de infiltração de água e seu armazenamento em perfis de solo; (ii) representação da condição não saturada do solo através da equação da curva característica proposta por Van Genuchten (1980), a qual foi utilizada no ajuste dos 
dados obtidos em laboratório; (iii) utilização de dados climáticos diários locais, como precipitação, evapotranspiração, velocidade do vento e temperatura do ar; (iv) multifuncionalidade em termos de condições de contorno; e (v) simplicidade de uso devido à sua interface autoexplicativa.

SEEP/W é um modelo numérico desenvolvido para simular matematicamente processos físicos reais de fluxo de água em meios particulados, em função do clima. Suas análises são dedicadas para fluxos estacionário e transiente saturado/não saturado em uma, duas ou três dimensões, através do método dos elementos finitos (MEF).

Além disso, é possível incluírem-se dados climáticos de evapotranspiração potencial, precipitação, radiação solar, velocidade do vento e temperatura. Caso não seja possível a obtenção de dados de evapotranspiração, o modelo permite estimá-la a partir dos dados de velocidade do vento e radiação solar pelos modelos de PenmanMonteith e Penman-Wilson.

Seu princípio de cálculo numérico, se baseia na solução da carga de fluxo da equação de Richards (1931), anteriormente citada no item 2.3.5, através do método de Galerkin de elementos finitos. Uma descrição dessa integração pode ser encontrada em Geoslope (2012b). A análise de infiltração ou fluxo no SEEP/W, segue o princípio da lei de Darcy, é solucionada pela Equação (21).

$$
\{Q\}=[K]\{H\}
$$

Onde:

$\{Q\}$ - vetor da quantidade de fluxo nos nós (ações);

$[K]$ - matriz de condutividade hidráulica, determinada pela curva característica (matriz de coeficientes relacionada às propriedades de geometria e materiais);

$\{H\}$ - vetor da carga hidráulica total nos nós (variáveis de campo ou desconhecidas).

As propriedades dos materiais, as quais são representadas pela matriz [K], são todos os inputs do programa, estipulados pelo usuário, determinados em laboratório e/ou 
estimados a partir de equações já existentes. As condições de contorno de infiltração são especificadas a partir de uma das matrizes fundamentais: $\{H\}$ ou $\{Q\}$.

Por exemplo, quando o usuário define a geometria, as propriedades dos materiais e o fluxo (condição de contorno), o simulador gerará soluções de pressão ou carga hidráulica. Quando a carga hidráulica é definida como condição de contorno, os resultados matemáticos desconhecidos serão em termos de fluxo. Ou seja, o simulador reunirá toda a informação definida pelo usuário em cada ponto de Gauss de cada elemento, aplica-a na equação de fluxo escrita em cada nó e, por fim, computa os valores desconhecidos, fluxo ou carga.

A relação entre a umidade/sucção e a condutividade hidráulica não saturada é definida a partir de modelos analíticos, tais como o de Van Genuchten (1980) e o de Fredlund et al. (1994). Desse modo, a estimativa ou determinação de funções de condutividade hidráulica utilizam a curva característica medida ou estimada ou a permeabilidade saturada dos materiais. No caso de se utilizar o ajuste de Van Genuchten (1980), tanto para a representação das curvas características quanto a de condutividade hidráulica, os dados de entrada do modelo referentes ao material de solo são:

- teores de umidade volumétricos saturado $\left(\theta_{\mathrm{s}}\right)$, residual $\left(\theta_{\mathrm{r}}\right)$ e inicial $(\theta)$;

- coeficiente de permeabilidade saturada $\left(\mathrm{k}_{\mathrm{sat}}\right)$;

- parâmetros geométricos da curva característica de ajuste do modelo.

Por outro lado, se por ventura a curva característica tiver que ser estimada pelo método de Aubertin et al. (2003) e a curva de condutividade hidráulica por Fredlund et al. (1994), os dados de entrada do respectivo material geotécnico são:

- umidade volumétrica saturada $\left(\theta_{\text {sat }}\right)$ ou porosidade $(\eta)$;

- diâmetro que passa $10 \%\left(D_{10}\right)$;

- diâmetro que passa 60\% (D60);

- limites de consistência;

- coeficiente de permeabilidade saturada (ksat). 
Por fim, após todas as análises serem realizadas, é possível obter-se os dados de saída (outputs) tais como dados climáticos acumulados na superfície, teores de umidade volumétrico, carga hidráulica e fluxo instantâneo e acumulado na superfície e em qualquer ponto do modelo. Os fluxos que saem do sistema ou malha, como escoamento e evaporação, são computados como negativos (-). Por outro lado, os fluxos hídricos que entram no sistema ou malha, como a infiltração e a precipitação, possuem sinal positivo (+), como mostra as cores através da Figura 34.

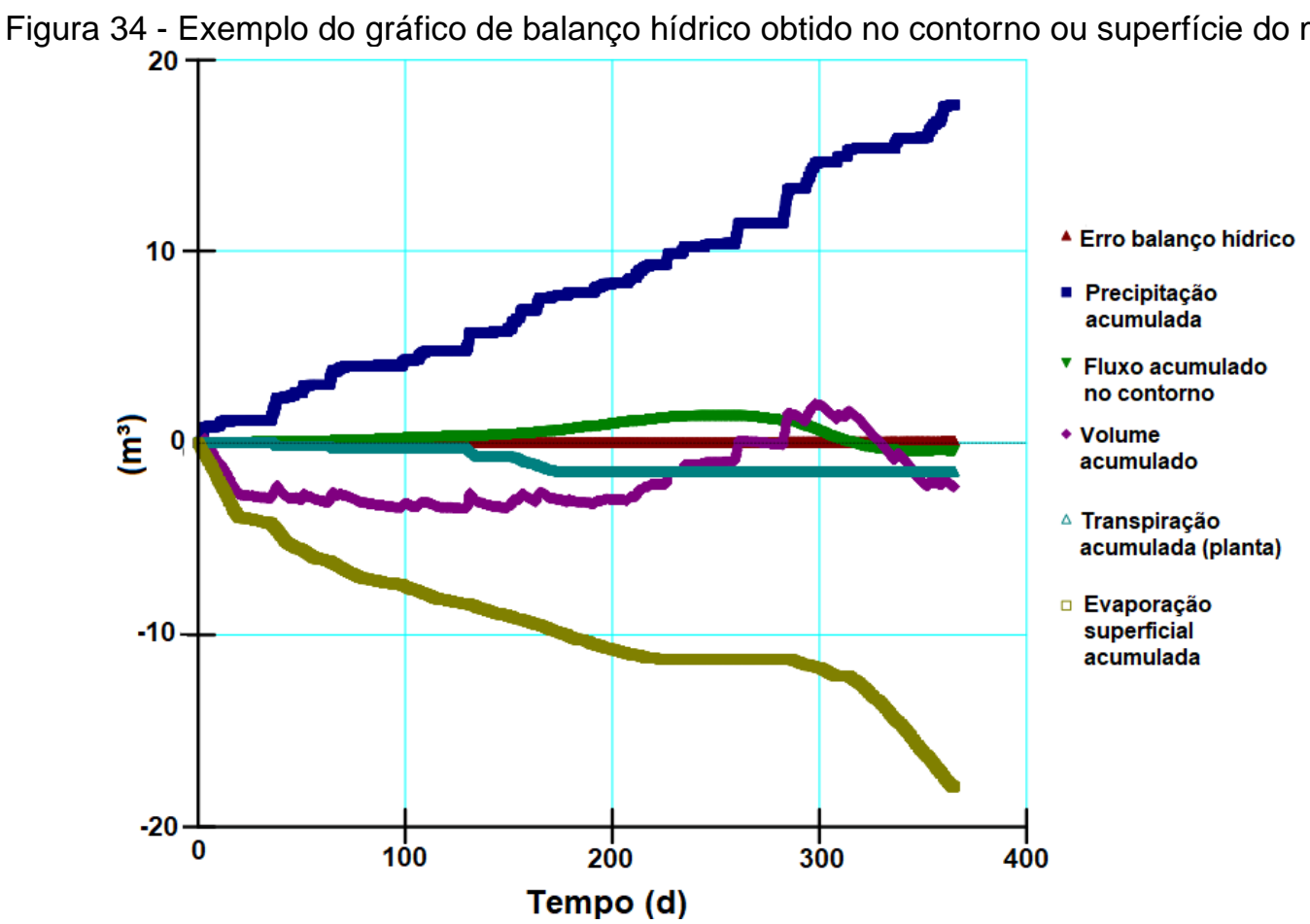

Fonte: adaptado de VADOSE/W Manual Geoslope (2014).

Vale comentar que, além das análises considerando o processo de fluxo de água isotérmico na fase líquida, através da diferença de pressão e da gravidade, o SEEP/W proporciona o desenvolvimento de simulações considerando o fluxo de água térmico e isotérmico na fase de vapor (Fick's law). O fluxo de vapor não foi abordado nesta pesquisa, pois, de acordo com Rose ${ }^{6}, 1963$ apud Camacho, 2002, o fluxo isotérmico de vapor de água pode assumir importância relativa maior que os fluxos na fase líquida, especialmente quando o solo apresenta sucções elevadas (maiores que 500 kPa), ou seja, quando a continuidade da fase líquida já não existe.

\footnotetext{
${ }^{6}$ ROSE, D. A. Water movement in porous materials: Part 2 - The separation of the components of water movement. British Journal of Applied Physics, 14, 491-496, 1963.
} 


\section{3 - MATERIAIS E MÉTODOS}

\section{1- Descrição do trabalho}

Este trabalho contou com a oportunidade de avaliação de um trecho de via permanente em operação, o qual foi reabilitado e aproveitado para a análise do subleito quanto à variação da umidade/sucção, ocasionada pela infiltração e evaporação de água relacionadas às condições climáticas locais, através de instrumentação de campo e de simulações em modelo numérico de fluxo de água.

Dados e informações relacionadas à construção e reabilitação do trecho foram abordados e descritos na dissertação de mestrado de Alves (2018), a qual deu início aos estudos na via desse local. O material de subleito coletado foi submetido à ensaios de módulo de resiliência em laboratório, em diferentes condições de saturação com base nos dados obtidos em campo, a fim de se tentar representar a influência climática no seu comportamento mecânico.

O monitoramento do subleito foi realizado através de sensores de medição do potencial matricial do solo e de um datalogger (ou aquisitor de dados), tendo sido executadas campanhas de medição semanais com o intuito de se verificar a condição de saturação e a variação dos valores de sucção do solo.

Paralelamente, um modelo numérico em elementos finitos de infiltração saturada/não saturada foi desenvolvido para simular e representar o fluxo transiente de água da chuva no perfil de subleito estudado. Tal modelagem foi realizada em função dos dados climatológicos da região onde a via foi construída.

Diante dos dados obtidos através do monitoramento de campo e da modelagem numérica, foram feitas as análises dos valores de sucção e umidade no perfil transversal da via ao longo do ano. Por fim, tais resultados foram comparados e utilizados como condicionante em ensaios de módulo de resiliência em laboratório. Parâmetros não determinados em laboratório foram estimados e/ou obtidos na literatura. A Figura 35 representa e resume a metodologia utilizada nesta pesquisa. 
Figura 35 - Esquema da metodologia do estudo

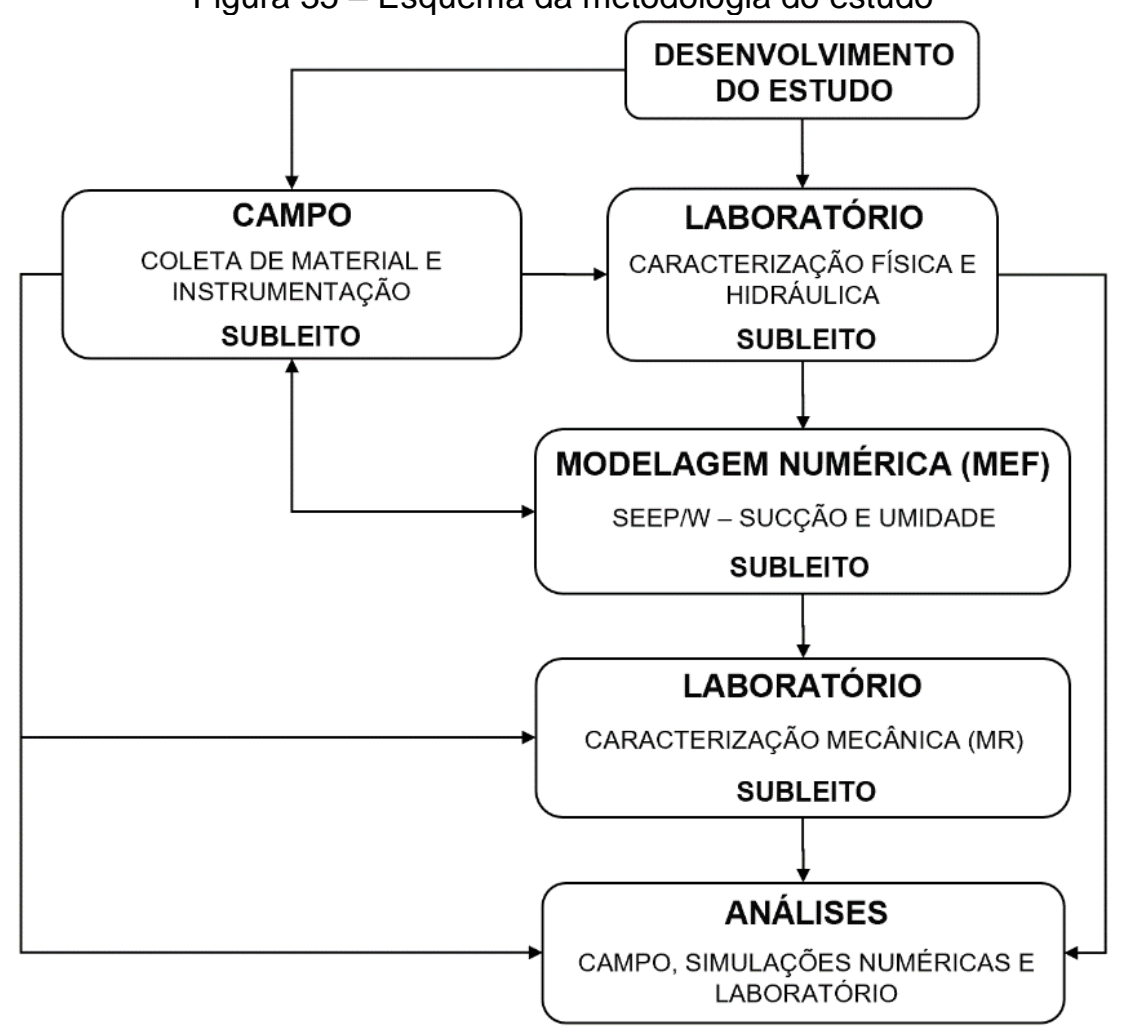

\section{2 - Trecho experimental}

\section{Localização e configuração da via permanente}

O trecho de via permanente estudado em questão está localizado entre as regiões de Piaçaguera e Raiz da Serra, próximo à cidade de Santos (litoral do Estado de São Paulo), sendo operado pela empresa MRS Logística (Figura 36).

Figura 36 - Trecho experimental: (a) coordenadas geográficas; (b) compactação do subleito

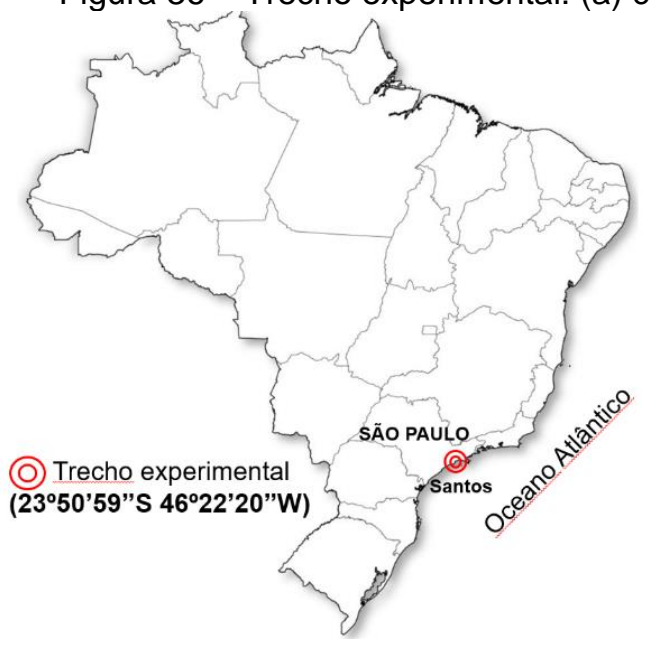

(a)

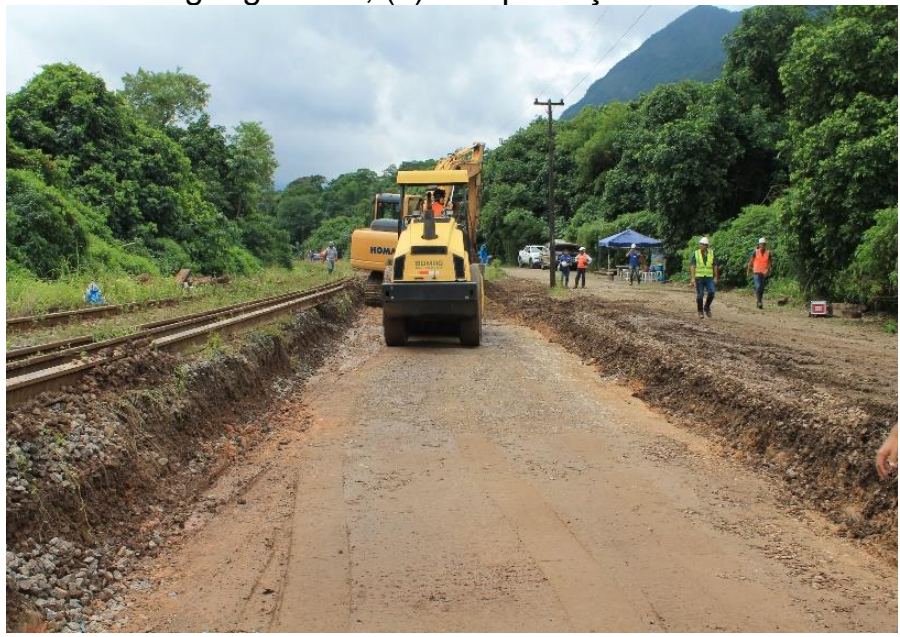

(b) 
De acordo com Alves (2018), o segmento foi implementado com a renovação de cerca de $0,50 \mathrm{~m}$ da camada de lastro da ferrovia, cuja construção foi feita em maio de 2017, sendo aplicado diretamente sobre o subleito e logo após submetido à processos de socaria. Segundo a mesma autora, a via na qual o trecho experimental foi construído tem previsão de transportar 91 milhões de toneladas brutas transportadas (MTBT's) em 2019 e 93 MTBT's em 2020. Suas condições operacionais, em termos de carga e velocidade, são aproximadamente $28 \mathrm{t} /$ eixo e $45 \mathrm{~km} / \mathrm{h}$, respectivamente. Observou-sese que seu perfil estrutural original é composto por bitola larga $(1,60 \mathrm{~m})$, trilhos TR-57 ou 115RE (AREMA), dormentes de madeira $(2,80 \times 0,24 \times 0,17 \mathrm{~m})$ espaçados em 0,54 m, fixações elásticas do tipo Deenik e uma camada de lastro assentada diretamente sobre o subleito.

O trecho abordado nesta presente pesquisa, com $20 \mathrm{~m}$ de extensão, compreende a seguinte configuração de subestrutura, aproximadamente: (i) 0,30 m de espessura de lastro; (ii) 0,10 m de espessura de sublastro granular de brita graduada simples (BGS), compactada sobre um subleito. Referente ao nível freático (NA), não foi possível observá-lo através de perfuração com trado helicoidal nas proximidades da via até $5 \mathrm{~m}$ de profundidade. A Figura 37 mostra a configuração do trecho abordado nesta pesquisa.

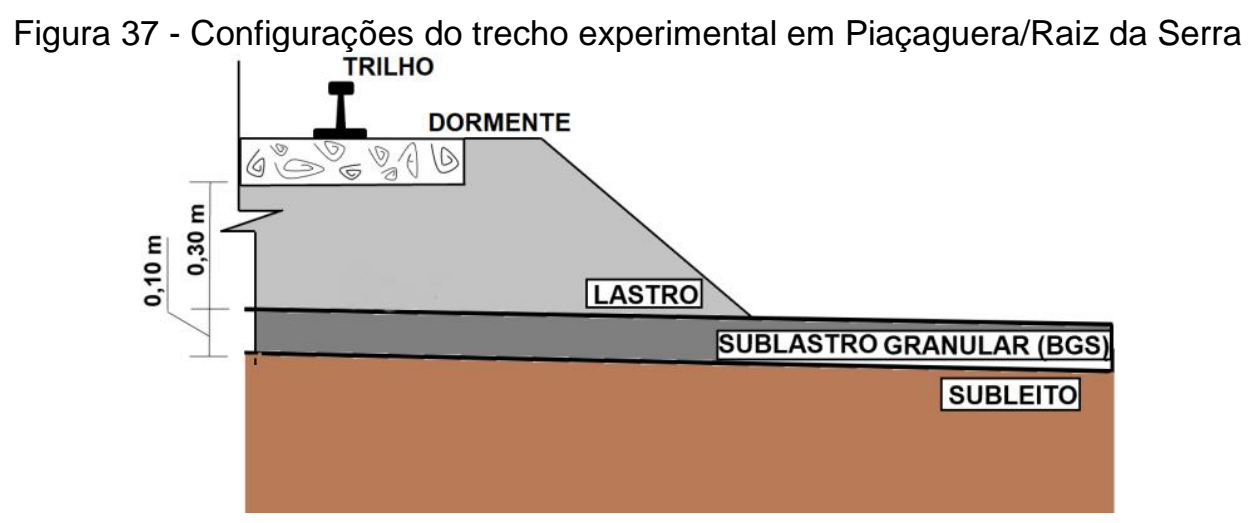

Solo e clima

No ano de 1859, quando a ferrovia em questão foi construída, os engenheiros responsáveis pela obra tiveram uma série de dificuldades, como às relacionadas às condições geotécnicas (solos muito erosivos) e climáticas (úmido e chuvoso durante o ano inteiro) locais (SOUKEF JUNIOR e BUSNARDO FILHO, 2016). 
Segundo Massad (1986), o solo dessa região foi formado através da ocorrência de uma distribuição caótica de argilas não lateríticas heterogêneas moles a muito moles (holocênicas). Estas são consideradas de baixa qualidade para obras civis, principalmente aquelas que solicitam cargas dinâmicas como as ferrovias, que devido ao fato de apresentarem elevada porcentagem de finos e não serem lateríticas, possuem elevada plasticidade, baixa capacidade de carga e resistência ao cisalhamento, tendo potencial para provocar recalques diferenciais na via. Dentro desse contexto, é importante relatar que se verificou a possível existência de uma camada de agregados graúdos (tipo rachão) sob a plataforma de solo na região do trecho experimental (provavelmente implementada com o intuito de proporcionar uma maior capacidade de suporte para a via). Tal observação foi feita quando da tentativa de perfuração da plataforma para a instalação de um poço de inspeção de nível d'água nas adjacências da via (a partir de uma determinada profundidade, aproximadamente 2 m, não foi mais possível penetrar o trado).

Com relação às condições climáticas do local, primeiramente é importante ressaltarse que o estado de São Paulo, localizado no sudeste do Brasil, possui uma estação seca e fria (abril a setembro) e outra úmida e quente (outubro a março) (BERNUCCI, 1995). Ademais, cidades costeiras da região, como Santos, possuem taxa de precipitação anual de aproximadamente 2000 mm (INMET, 2018). A Figura 38 apresenta a média mensal de precipitação, evaporação total (Piche), fluxo efetivo e temperatura em Santos de 1981 a 2010.

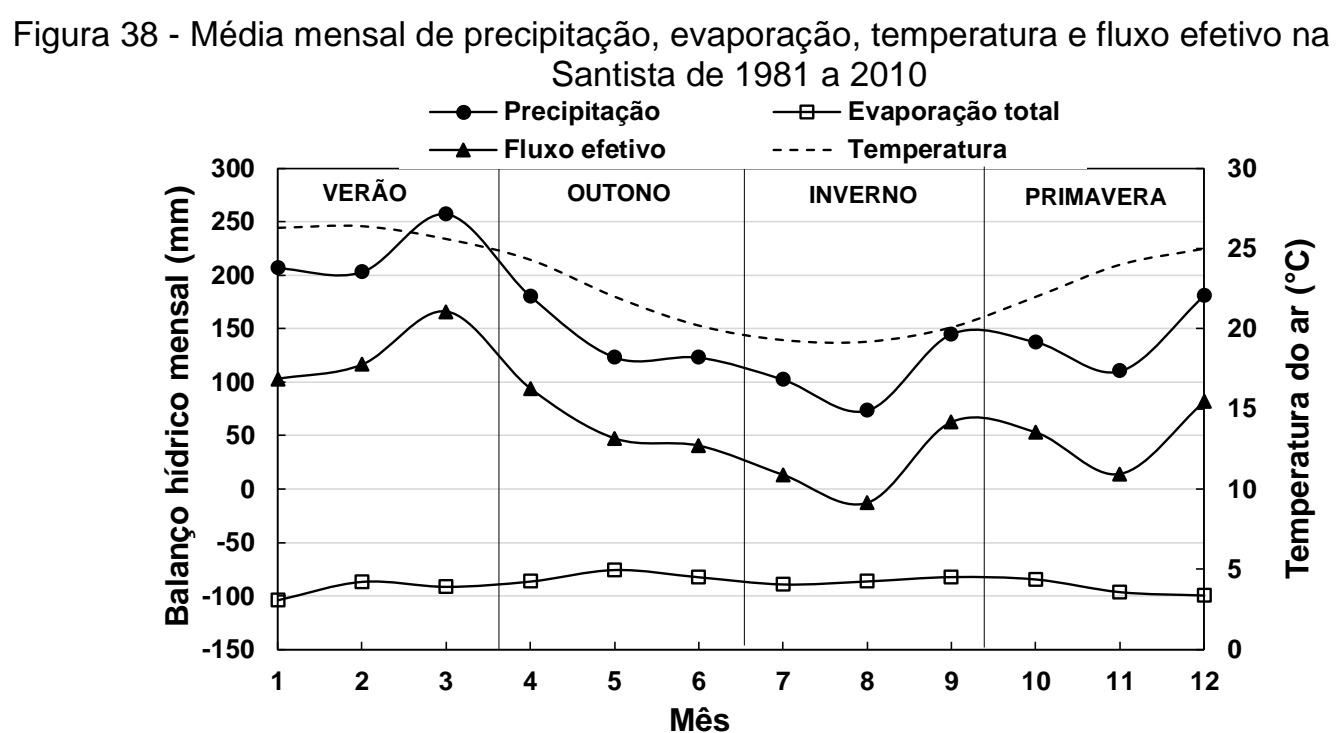

Fonte: INMET (2018). 
Durante a maior parte do ano, a taxa de precipitação excede a taxa de evaporação (fluxo efetivo positivo de água na superfície), podendo provocar um constante excesso de água nos poros do solo de subleito e, consequentemente, um excedente hídrico. Por outro lado, o segundo semestre é caracterizado pela estação menos úmida, em função dos menores valores de fluxo efetivo, evidenciando taxas de evaporação um pouco superior a taxas de precipitação entre os meses de julho e agosto. Adicionalmente, existem intensas variações da temperatura diária. No inverno, ventos provenientes do Noroeste, os quais precedem frentes frias, tendem a elevar a temperatura a $35^{\circ} \mathrm{C}$ ao meio dia, enquanto que promovem uma redução para até $25^{\circ} \mathrm{C}$ pela manhã. $O$ verão em janeiro é usualmente considerado quente, variando entre temperaturas mínimas e máximas médias de $23^{\circ} \mathrm{C}$ a $30^{\circ} \mathrm{C}$, respectivamente. Por outro lado, o inverno em julho alcança temperaturas mínimas e máximas médias de $17^{\circ} \mathrm{C}$ a $24^{\circ} \mathrm{C}$, respectivamente.

\section{Coleta de amostras de solo}

Durante a coleta das amostras observou-se água retida e acumulada no subleito, grãos de lastro misturados ao solo e bombeamento de finos até a superfície do lastro (Figura 39). Cui (2016) comenta que esta camada composta de lastro e solo ou interlayer, é provocada pelo carregamento cíclico e pelo acúmulo de água em solos finos. Ações de incontáveis socarias também podem contribuir para esse fenômeno. Desse modo, devido ao elevado grau de contaminação, não foi possível identificar-se o topo do subleito (separação das camadas de lastro e solo), precisamente.

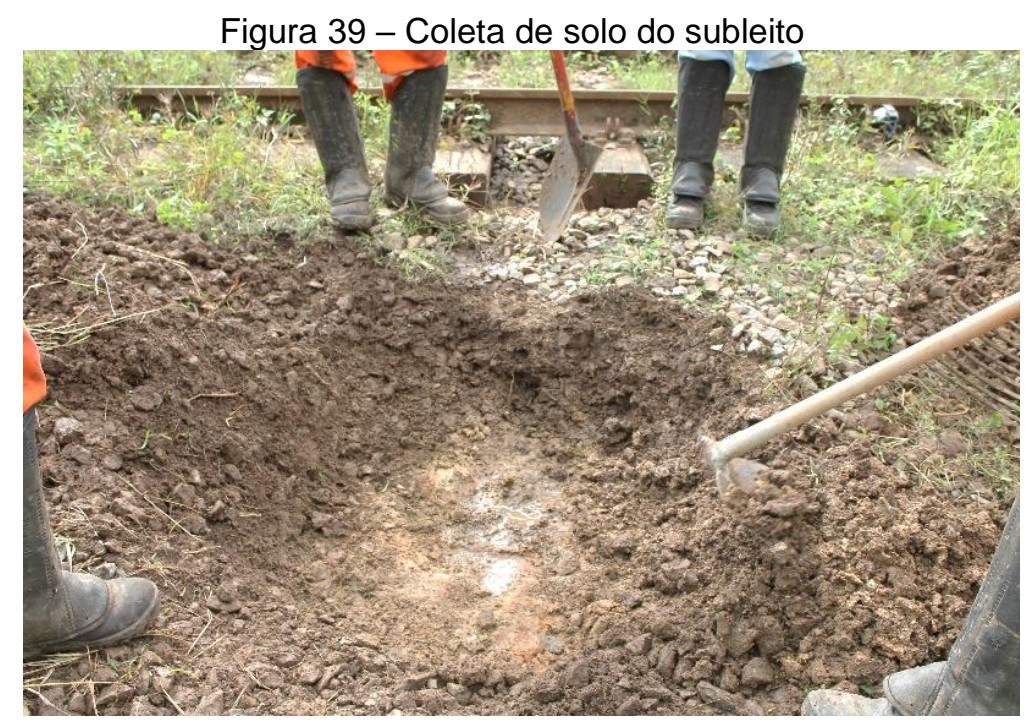


As amostras coletadas foram acondicionadas em sacos plásticos devidamente identificados, sendo posteriormente armazenados no Laboratório de Tecnologia de Pavimentação (LTP) da Escola Politécnica da USP. Prosseguiu-se com a realização de ensaios para caracterização física e hidráulica: análise granulométrica, densidade dos grãos $\left(G_{s}\right)$, massa específica natural $(\gamma)$, massa específica aparente seca $\left(\gamma_{d}\right)$, limites de Atterberg (liquidez e plasticidade), permeabilidade saturada e curva característica do solo.

Vale ressaltar que, além das amostras de solo do subleito, também foram coletadas amostras de material da camada de sublastro que seria instalada no trecho experimental para determinação da curva granulométrica e características hidráulicas.

\section{3 - Programa experimental em laboratório}

A análise granulométrica do lastro, sublastro e subleito, além da classificação MCT e da avaliação mineralógica deste último, foram realizadas e obtidas por Alves (2018), sendo descritos abaixo, os procedimentos e normas utilizados pela autora.

\subsection{1 - Caracterização física dos materiais}

\section{Análise granulométrica}

As análises granulométricas dos materiais de subleito do trecho experimental foram realizadas conforme a ABNT (NBR-7181/2016), por peneiramento e sedimentação. $\mathrm{Na}$ preparação das amostras foi utilizado o procedimento com secagem prévia ao ar e destorroamento da amostra, conforme recomendado pela ABNT (NBR-6457/2016). Com relação às amostras do sublastro granular e do lastro, ambos oriundos de rocha granítica, estes foram submetidos ao processo de peneiramento, de acordo com a ABNT (NM 248/2003).

Segundo Alves (2018), o sublastro granular utilizado em campo foi dimensionado de acordo com a Faixa C da norma (DERSA PE-D00/08), tendo sido esta faixa 
considerada viável do ponto de vista do critério de filtro de Terzaghi proposto em 1922, quanto ao entupimento e à permeabilidade, representado pelas equações 22 e 23.

$$
\begin{gathered}
D_{15}(\text { camada filtro }) \leq 5 D_{85}(\text { subleito }) \\
D_{50}(\text { camada filtro }) \leq 25 D_{50}(\text { subleito })
\end{gathered}
$$

Onde:

$D_{15}$ - diâmetro equivalente à porcentagem de 15\% passante;

$D_{85}$ - diâmetro equivalente à porcentagem de 85\% passante;

$D_{50}$ - diâmetro equivalente à porcentagem de $50 \%$ passante.

Ressalta-se que caso tivesse sido utilizado solo coesivo no sublastro, como o laterítico, o critério de filtro seria questionável, podendo até mesmo não ser atendido. A possibilidade de trincamento e aparecimento de fissuras durante a sua contração e/ou expansão pode permitir novamente a ocorrência do bombeamento de finos e, consequentemente, a contaminação do lastro. Além disso, um sublastro coesivo ou de baixa permeabilidade, pode gerar uma barreira para a água presente no subleito, impedindo a sua drenagem e mantendo-o próximo à saturação.

\section{Densidade real dos grãos}

A densidade dos grãos do solo de subleito foi obtida através dos procedimentos da norma (DNER-ME/093/94), com uso de amostra preparada com secagem prévia. Com relação ao material de sublastro granular (BGS), as densidades dos agregados graúdos e miúdos foram obtidas pela empresa USICITY.

Para representar-se o lastro de campo, os dados de densidade real dos grãos, massa específica aparente seca $\left(\gamma_{s}\right)$, porosidade ( $\eta$ ) e índice de vazios (e) foram obtidos em Merheb (2014), após comparações com Wnek et al. (2013) e Costa (2016). Os dados de Merheb (2014) foram aplicados neste estudo devido: (i) ao mesmo tipo de rocha, caracterizada como granítica; (ii) a distribuição granulométrica (AREMA 3); e (iii) pela condição estabilizada ou densificada (situação após tráfego com o tempo). 


\section{Limites de Atterberg e classificação do solo}

Os limites de consistência de Atterberg (liquidez e plasticidade) foram obtidos pelas normas ABNT (NBR-6459/2016) e (NBR-7180/2016).

Com relação à classificação do solo estudado, cinco métodos foram utilizados: análise táctil-visual (ASTM D2488-17), Sistema Unificado de Classificação de Solos (SUCS) (ASTM D2487/17), Highway Research Board (HRB) (ASTM D3282/15), Miniatura Compactada Tropical (MCT) e Método Expedito de Classificação de Solos (NOGAMI e VILLIBOR, 1981, 1994; DNER-ME 228/94; DNER-ME 256/94; DNER-ME 258/94; e DNER-CLA 259/96).

\section{Curva de compactação}

O ensaio para a obtenção da curva de compactação do solo e do sublastro foi realizado conforme os procedimentos da norma ABNT (NBR-7182/2016). Para o solo de subleito aplicou-se energia Proctor Normal, com reuso, levando em consideração a ausência de controle durante o processo de compactação em campo. A compactação do material de sublastro granular em laboratório foi realizada aplicandose energia Proctor Modificado, sem reuso, conforme exigido pela norma (DERSA ETDE-P00/008) e não levou em consideração as adversidades construtivas durante o processo de compactação em campo, o qual não passou por controle de qualidade.

Além disso, os dados da curva de compactação obtidos por Alves (2018) através do Proctor Normal para o mesmo material desta pesquisa (FAIXA C), e Virgiliis (2009), através do Proctor Modificado, para uma outra BGS (FAIXA B), foram considerados nesse estudo para fins de comparação e aplicação em modelo numérico.

\section{Mineralogia}

Foi realizado a identificação da estrutura mineralógica do material de solo do subleito. Para tanto, aplicou-se o método da Difração de raios $X$ que compreende o emprego 
de difratômetro de Raios X com detector sensível à posição, do Laboratório de Caracterização Tecnológica (LCT) da Escola Politécnica da USP.

\subsection{2 - Caracterização hidráulica dos materiais}

\section{Permeabilidade ( $\left.k_{\text {sat }}\right)$}

A permeabilidade do solo de subleito foi determinada no Laboratório de Mecânica dos Solos (LMS) da Escola Politécnica da USP, através do permeâmetro triaxial de carga variável, conhecido por Tri-flex 2, segundo a norma ASTM (D5084-16a), seguindo-se os procedimentos adotados por Maciel (2003), Mendes (2008), Mariano (2008), Cardoso (2006) e Lopes (2011). Durante a realização do ensaio, foi considerada a anisotropia do material, ou seja, a permeabilidade saturada nas direções y e x. Por isso, a amostra foi torneada e assentada na base do permeâmetro em duas posições: paralela e perpendicular à compactação (Figura 40).

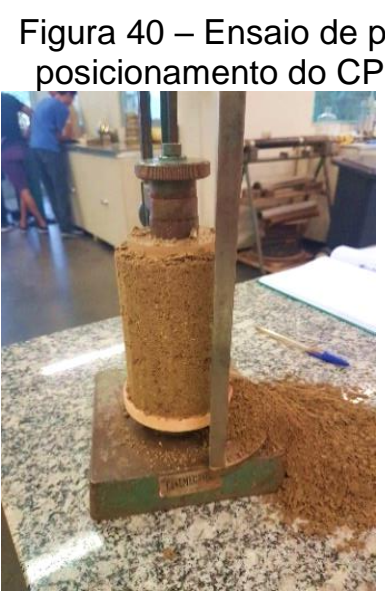

(a)

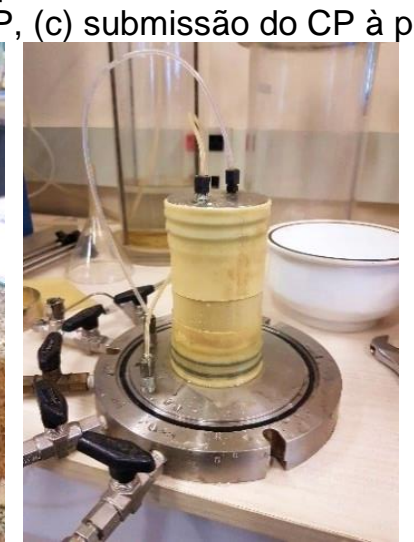

(b)

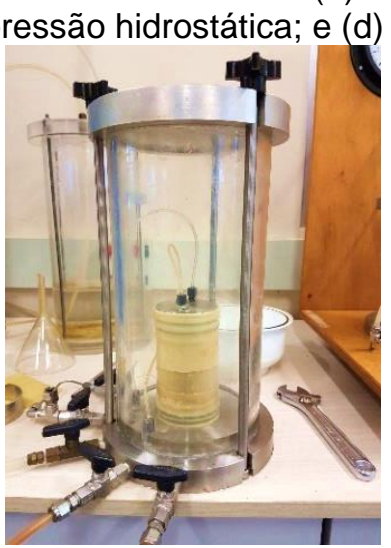

(c)

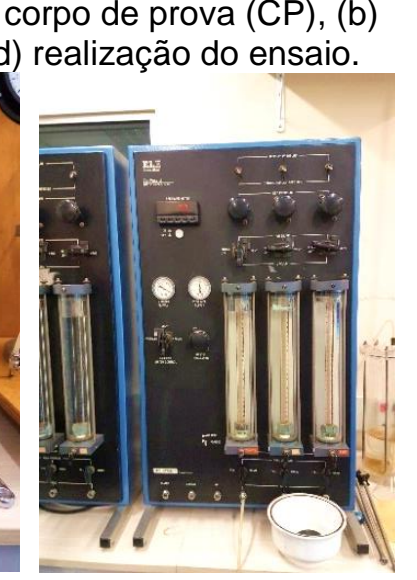

(d)

Devido as dificuldades encontradas na realização do ensaio de permeabilidade saturada do sublastro granular (BGS), seu valor foi estimado através da equação proposta por Moulton (1980) (Equação 24). Além disso, consultou-se Suzuki et al. (2013), que determinou a permeabilidade de britas graduadas classificadas pela Faixa C e B (DERSA ET-P0/005) através da mesma equação, constatando que são iguais $\left(3,66 \times 10^{-4} \mathrm{~cm} / \mathrm{s}\right)$.

$$
k=2,192 \times 10^{2} \times d_{10}^{1,478} \times \eta^{6,654} \times P_{200}^{-0,597}
$$


A equação de Moulton (1980) é função da porcentagem que passa na peneira $n^{0} 200$ $\left(P_{200}\right)$, do diâmetro efetivo $\left(D_{10}\right)$ e da porosidade $(\eta)$. Ou seja, a variação desses parâmetros, seja através da incorporação de uma quantidade maior de finos, ou devido à uma compactação mais energética, pode ocasionar a variação da permeabilidade. O lastro foi considerado uma camada de elevada porosidade (n) e sem capacidade de retenção de água, ou seja, sem contaminação. A permeabilidade saturada foi calculada através da equação de Moulton (1980) a partir dos seus dados de granulometria e comparada com dados da literatura, obtidos através de ensaios com permeâmetros em larga escala, como os realizados por Tenakoon et al. (2012).

\section{Curva característica (SWCC)}

Com o intuito de se determinar a curva característica do solo pelas trajetórias de secagem e umedecimento (histerese), a fim de se tentar reproduzir as possíveis variações sazonais da sucção no subleito ferroviário, além de diminuir a complexidade e o tempo para a sua obtenção, foram utilizados três métodos: (i) placas de sucção e pressão e papel filtro (método 1); (ii) sensores de medição de sucção Watermark e papel filtro (método 2); e (iii) sensores de sucção TEROS-21 (método 3).

No método 1, o primeiro trecho da curva característica do material de solo foi determinado através da aplicação da placa de sucção (Figura 41). O uso desse dispositivo foi aliado ao uso da placa de pressão, para a definição do segundo trecho.

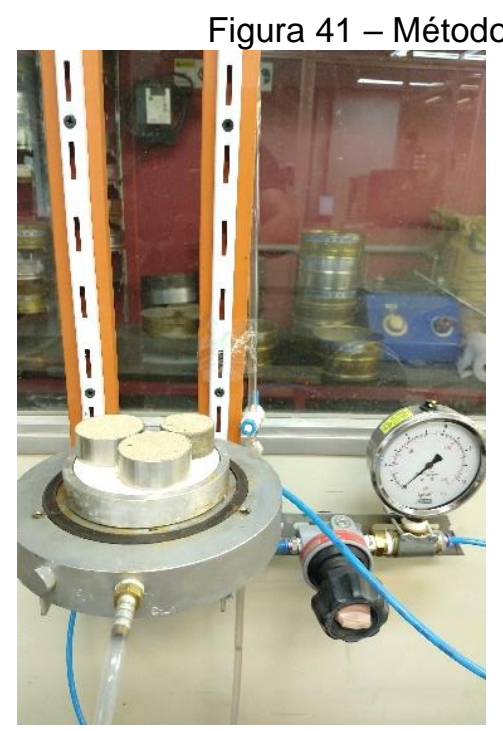

(a)

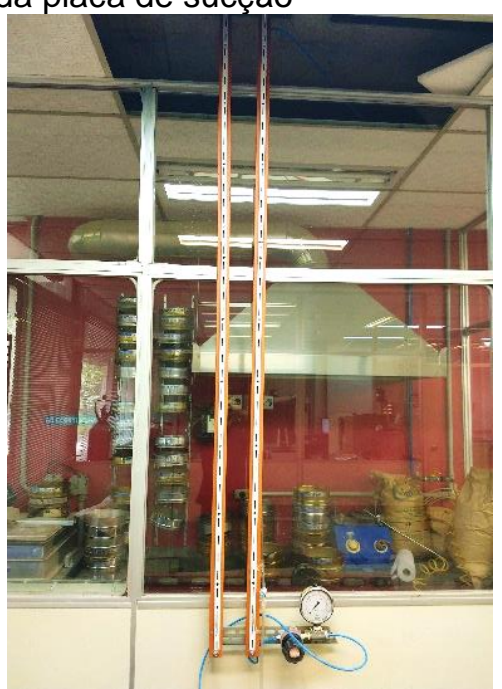

(b) 
A preparação e compactação das amostras foi realizada seguindo dois critérios: (i) a necessidade de se determinar a curva característica para quatro condições de umidade (Wót, Wót $+2 \%$, Wót $+4 \%$ e Wót $+6 \%$ ), ou seja, quatro corpos de prova (Figura 42); (ii) tamanho da pedra porosa para o posicionamento simultâneo das amostras. Desse modo, recorreu-se ao método de compactação estática do solo com prensa hidráulica em pequenos cilindros de diâmetro e altura padronizadas $(3,8 \times 2,0 \mathrm{~cm}$, respectivamente).

Figura 42 - Mini-CP's $(3,8$ × 2,0 cm) compactados estaticamente para a obtenção da SWCC

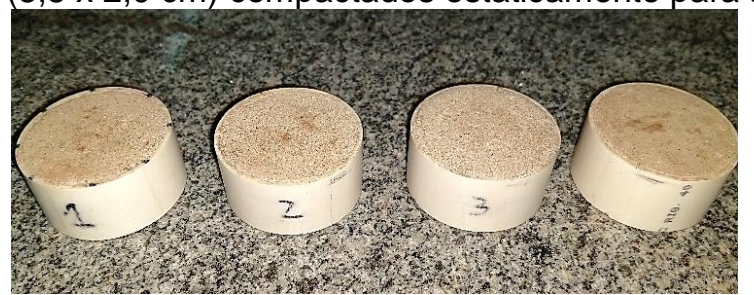

Após a compactação do material de solo, realizou-se a saturação da pedra porosa através de um almofariz pressurizado por 3 dias. Logo em seguida, as amostras foram posicionadas sobre a placa de sucção onde a pedra porosa estava instalada e o ensaio foi iniciado. A altura máxima que a placa atingiu durante o ensaio em laboratório foi de $3 \mathrm{~m}$, correspondendo à um valor de sucção de $30 \mathrm{kPa}$. A partir deste valor, posicionaram-se as amostras de solo sobre a pedra porosa da placa de pressão, com entrada de ar de $400 \mathrm{kPa}$, aplicada no trabalho de Oliveira (2004), conforme a Figura 43.

Figura 43 - Placa de pressão ou "panela"

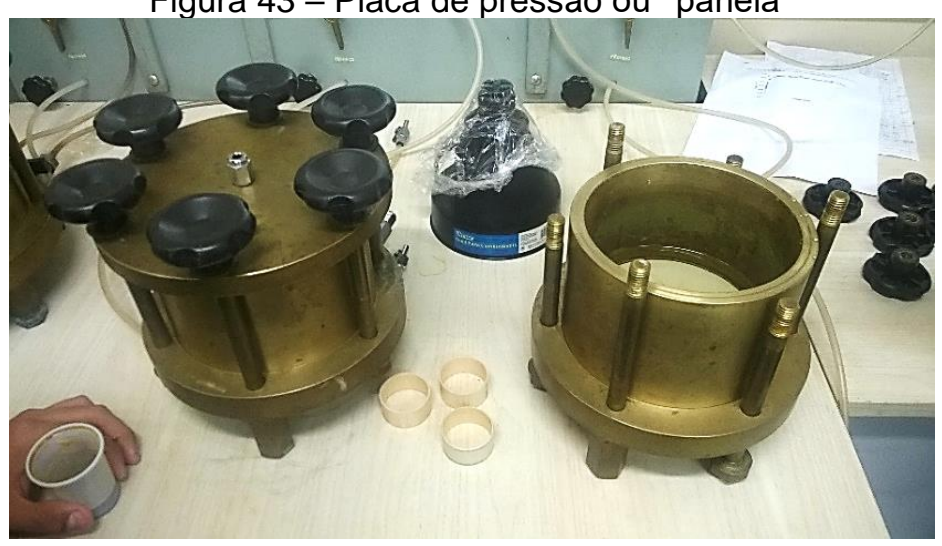

Segundo Chard (2004) e Ganjegunte et al. (2012), é possível se determinar a relação entre a umidade volumétrica e sucção matricial através de sensores Watermark 
200SS devidamente inseridos em solo compactado dentro de recipientes de volume conhecido. Tal método foi utilizado por Ganjegunte et al. (2012) para verificar a acurácia do sensor pela obtenção dos valores de umidade volumétrica, a partir da relação umidade-sucção de uma curva de retenção conhecida, com dados de umidade volumétrica obtidos através da pesagem e determinação de volume diários de um corpo de prova (CP) compactado em laboratório.

Com base nos autores citados, para o método 2 determinou-se a curva característica do solo a partir da utilização de dois sensores Watermark inseridos no topo e na base do corpo de prova compactado dentro do cilindro grande Proctor, de diâmetro $15 \mathrm{~cm}$ e altura $23 \mathrm{~cm}$. A compactação do material de solo foi realizada nas suas condições de umidade ótima e densidade máxima, deixando uma pequena sobra ou espaço vazio no topo do corpo de prova para possível expansão do solo durante umedecimento por imersão em tanque com água. A Figura 44 apresenta o esquema de moldagem e o posicionamento dos sensores em solo compactado dentro do cilindro.

Figura 44 - Determinação da curva característica a partir de sensores Watermark 200SS: (a) esquematização; (b) instalação.

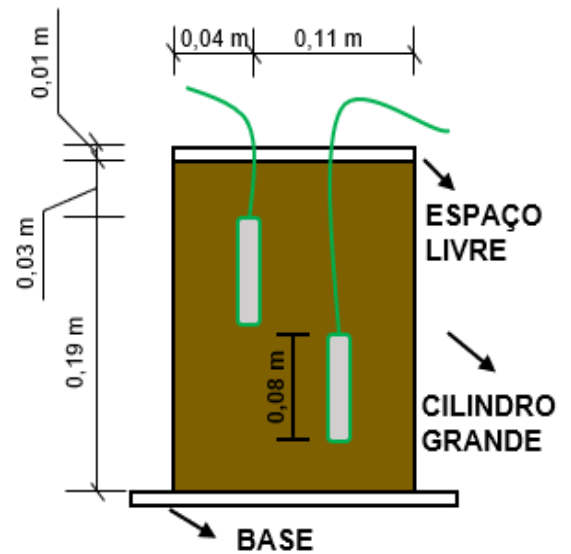

(a)

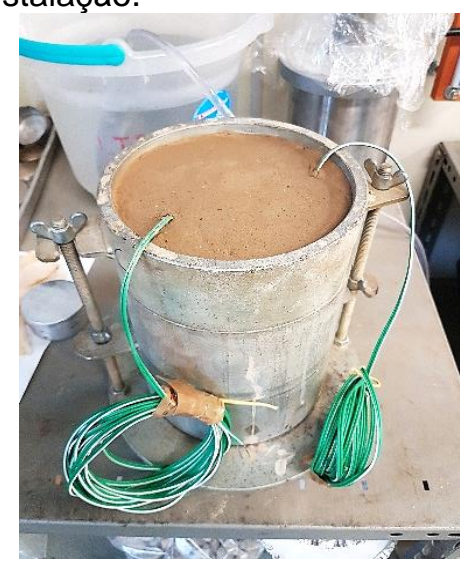

(b)

O procedimento de perfuração foi realizado de acordo com o manual do fabricante e Mendes (2008). Através de uma marreta e um cilindro com bordas em forma de lâmina, perfurou-se o corpo de prova em dois pontos, próximos ao fundo (ponto A) e a superfície (ponto B), com diâmetro um pouco maior que correspondente ao diâmetro do sensor, de tal modo a permitir a instalação dos sensores e posterior reaplicação do solo extraído misturado com água. Os sensores foram posicionados de tal forma a 
estar devidamente em contato ("arrodeado") com o solo, ou seja, a fim de não sofrer nenhuma influência de contato da parede metálica do cilindro e do furo utilizado pelo outro sensor. Após a instalação dos sensores devidamente saturados e a reposição do solo no seu respectivo furo, colocou-se o conjunto (base perfurada, cilindro e colarinho metálicos, solo compactado e sensores), em um tanque com água e deixado até a sua saturação.

O controle de saturação foi realizado a partir do cálculo de seus índices físicos como também, pela leitura dos sensores, até aferir $0 \mathrm{kPa}$ de sucção correspondendo a um material saturado. Logo em seguida, deixou-se o material drenar e realizaram-se pesagens diárias e verificação da sua umidade volumétrica, tanto quanto a leitura de ambos os sensores.

O monitoramento da sucção se deu por um logger 900M Monitor desenvolvido pela Irrometer. O logger, desenvolvido para efetuar medições em campo, possui intervalo de leitura que vai de 1 min a $24 \mathrm{~h}$, podendo também ser utilizado para medições instantâneas. Foi determinado um intervalo de coleta de dados de 2 em 2 h, considerando que este seria suficiente para que o solo pudesse drenar de forma controlada e, então, passasse pelo procedimento de pesagens.

A partir da experiência obtida com estes sensores, verificou-se que foi atingido o limite de medição destes (sucção de $239 \mathrm{kPa}$ ), o que foi considerada uma limitação. Além disso, pelo fato de tais sensores terem sido instalados em uma grande quantidade de solo compactado, notou-se dificuldade na drenagem do solo, tornando o processo bastante lento.

Dentro deste contexto, para o método 3 buscou-se repetir o mesmo procedimento, desta vez com sensores TEROS-21, capazes de medir sucções mais elevadas, utilizando-se corpos de prova de solo compactado nas mesmas condições de densidade e umidade, em cilindro pequeno Proctor (diâmetro $=10 \mathrm{~cm}$ e altura $=18$ $\mathrm{cm}$, aproximadamente). A Figura 45 mostra fotos do procedimento adotado na utilização do sensor TEROS-21. 
Figura 45 - Determinação da curva característica do solo utilizando-se sensores Teros-21: (a) esquematização; (b) instalação

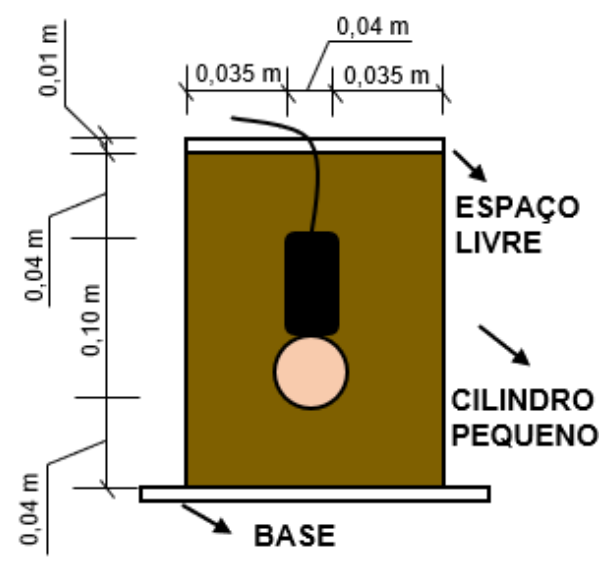

(a)

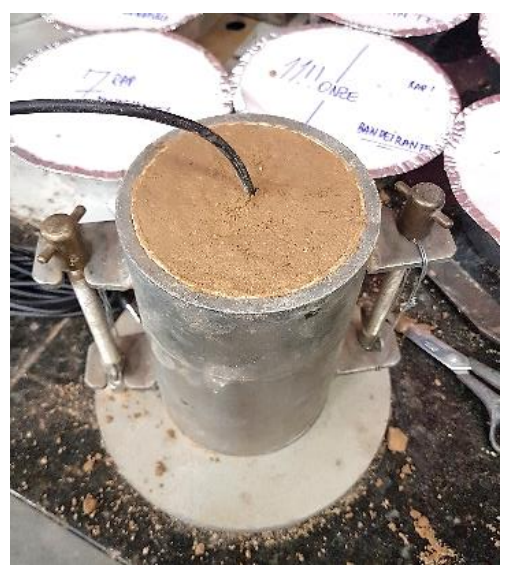

(b)

O processo de saturação também foi realizado a partir da imersão do cilindro em tanque com água. Durante a saturação, um colarinho de diâmetro compatível com o cilindro pequeno foi colocado em sua superfície de modo a se verificar a expansão do solo e evitar perda de material. Tal processo foi controlado através do cálculo de índices físicos e medição da sucção do solo através do sensor, quando o mesmo indicou $-9 \mathrm{kPa}$, considerado o limite inferior de medida de sucção para este instrumento.

Assim como o sensor Watermark, a coleta e armazenamento de dados da sucção pelo TEROS-21 se deu por um logger Em50. O logger, foi projetado também para aplicação em campo e possui intervalo de leitura que vai de $1 \mathrm{~min}$ a $24 \mathrm{~h}$, utilizado também para medições instantâneas.

Considerando-se a limitação das placas de sucção e de pressão no método 1, devido ao valor da entrada de ar da pedra porosa utilizada, foi necessária a aplicação do papel filtro para a obtenção dos valores de sucção do solo após $400 \mathrm{kPa}$. Tal procedimento também foi aplicado no corpo de prova compactado em cilindro grande Proctor, no qual foi possível realizarem-se medições de sucção até $239 \mathrm{kPa}$, considerado o limite superior de aferição dos sensores Watermark 200SS, no método 2.

O ensaio do papel filtro foi realizado conforme a norma ASTM D5298-16. Levando-se em conta o tamanho do corpo de prova e a elevada possibilidade de não 
uniformização da umidade e sucção na superfície e na base, foram utilizados 4 papéis filtros, dois no topo e na base, um em cada porção da sua área total. Foi colocada uma base metálica na superfície superior a fim de garantir o contato pleno do papel filtro com o corpo de prova. $O$ contato dos papéis filtro da base foi garantido em função da própria massa do conjunto. A uniformização da umidade do corpo de prova com o papel filtro durou 7 dias e foi obtida conforme recomendado por Marinho $(1994 ; 1995)$ (Figura 46).

Figura 46 - Método do papel filtro: (a) corpo de prova $(3,8 \times 2,0 \mathrm{~cm})$; (b) aplicação do papel filtro; (c) empacotamento do corpo de prova por 7 dias; (d) retirada do papel filtro para pesagem

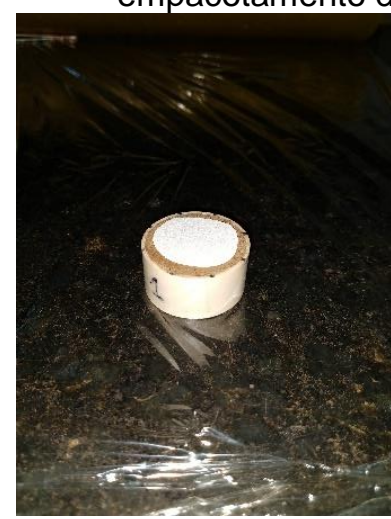

(a)

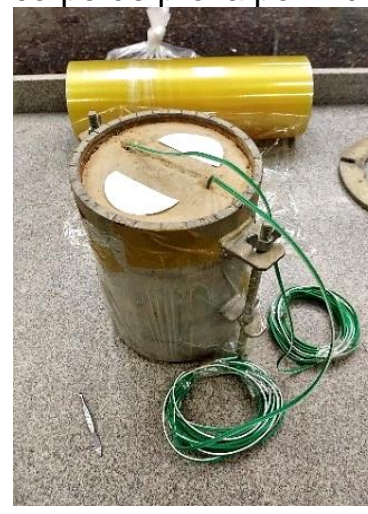

(b)

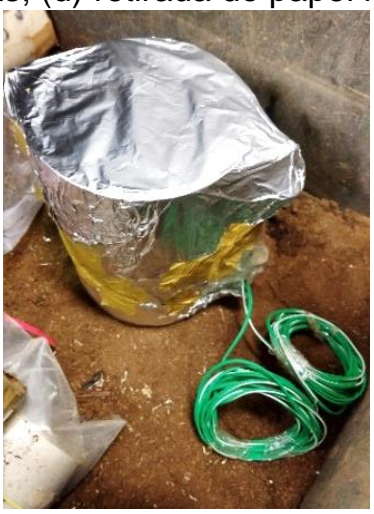

(c)

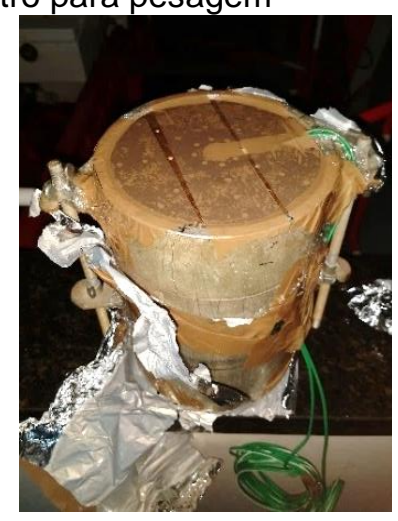

(d)

Após a determinação dos pontos experimentais pelos três métodos expostos, a curva foi determinada a partir do modelo de Van Genuchten (1980) (Equação 6). Os parâmetros de ajustes foram determinados de tal forma que o erro calculado fosse mínimo. Desse modo, foi utilizado o critério de aceitação de ajuste proposto por Gerscovich (2001) para solos tropicais utilizando-se o método dos mínimos quadrados, sugerindo um valor de erro menor do que 4 (Equação 25).

$$
\varepsilon=\frac{1}{N} \cdot \sum_{i=1}^{N}\left(\theta_{i}-\theta^{\wedge}{ }_{i}\right)^{2}<4
$$

Onde:

$\varepsilon$ - erro;

$\theta_{i}$ - teor de umidade volumétrico previsto;

$\theta^{\wedge}{ }_{i}$ - umidade medida;

$N$ - número total de pontos experimentais. 
Com relação aos materiais de lastro e sublastro, foi utilizado o modelo desenvolvido por Aubertin et al. (2003), modificado do modelo de Kovacs proposto em 1981, que torna possível estimar-se a curva característica do material através da sua porosidade (n), granulometria $\left(D_{10}\right.$ e $\left.D_{60}\right)$ e limites de consistência (LL e LP).

Ressalta-se que este método é aplicável para materiais granulares, como a BGS. Yaghoubi et al. (2016) utilizaram a equação de Aubertin et al. (2003) para a determinação da curva característica de materiais granulares de faixa granulométrica parecida com a FAIXA C da BGS, com partículas de tamanho máximo $19 \mathrm{~mm}$.

\subsection{3 - Caracterização mecânica do solo de subleito}

Para avaliar-se e simular-se a influência da variabilidade da condição de saturação/sucção no comportamento mecânico de um solo de subleito ferroviário, ensaios de módulo de resiliência foram realizados em diferentes condições de umidade de compactação, conforme as normas DNIT 134/2010 e DNIT 134/2017.

Para tanto, tal material foi compactado em molde cilíndrico $(10 \mathrm{~cm} \times 20 \mathrm{~cm})$ e submetidos aos seguintes processos: (i) umedecimento-secagem; (ii) secagemumedecimento; (iii) umedecimento; e na (iv) umidade ótima (Figura 47). Essas simulações foram realizadas objetivando-se simularem-se possíveis condições reais de campo, como também, aquelas obtidas através das simulações numéricas e da curva caraterística obtida pelo método 3, apresentada no item 3.2.2.

Figura 47 - Módulo de resiliência: (a) destorroamento; (b) moldagem; (c) posicionamento; (d)

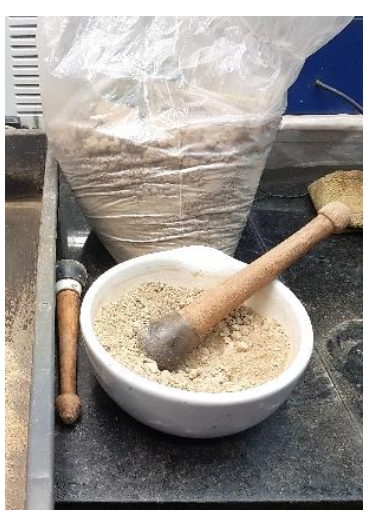

(a)

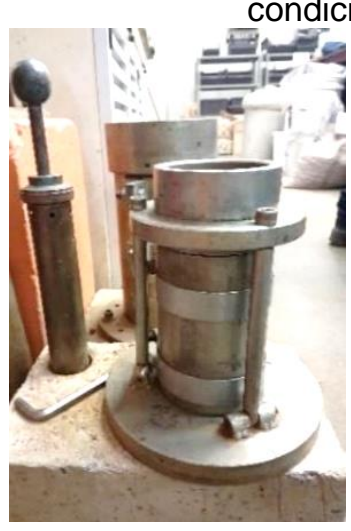

(b)

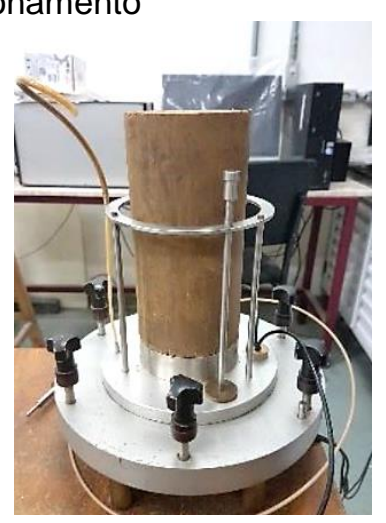

(c)

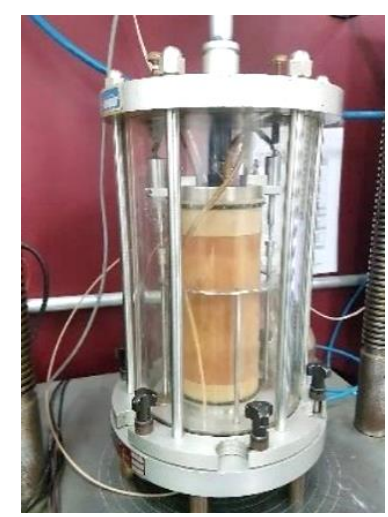

(d) 
Com relação ao processo de secagem e umedecimento, foram executadas as seguintes etapas: (i) compactação na umidade ótima; (ii) secagem até $5 \%$ de umidade; (iii) umedecimento em câmara umidificadora até a umidade de 15\%; e (iv) realização do ensaio de módulo de resiliência.

O processo de umedecimento e secagem foi realizado baseando-se nos seguintes procedimentos: (i) compactação e moldagem do solo na umidade ótima; (ii) umedecimento em câmara umidificadora até $23 \%$ de umidade; (iii) secagem até a umidade de 15\%; (iv) realização do ensaio de módulo de resillência. É importante comentar que, nesse processo, durante a trajetória de secagem de um dia para o outro, a umidade do solo alcançou 14\%. Considerando-se a pequena diferença entre o valor de umidade desejado (15\%) e o encontrado (14\%), decidiu-se aspergir, aproximadamente, $30 \mathrm{~g}$ de água para umedecer novamente a amostra até $15 \%$ de umidade, como previamente havia sido determinado, para então realizar-se o ensaio.

\section{4 - Programa experimental em campo}

Para que se possa entender o comportamento hidráulico da via férrea em função do clima, é crucial realizar-se monitoramento com as condições climáticas e geotécnicas reais de campo. Para tanto, cinco sensores foram instalados em diferentes profundidades $(0,10 \mathrm{~m}$ e $0,30 \mathrm{~m})$ e espaçados lateralmente entre eles $(0,80 \mathrm{~m})$ em um perfil transversal da via, afim de se investigar a variação de sucção ou comportamento hidráulico do solo em condições reais. A Figura 48 apresenta a o posicionamento dos sensores de sucção em campo.

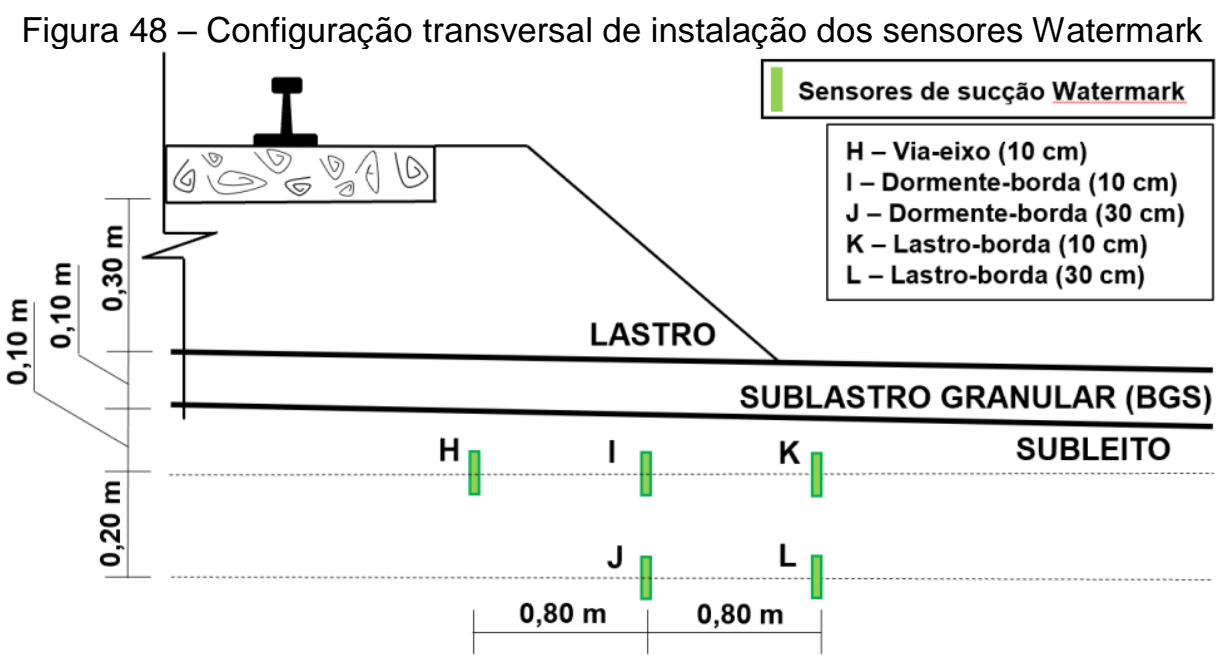


Como já mencionado no item 2.3.4, os sensores de matriz granular nomeados por Watermark 200SS têm como função medir a sucção matricial indiretamente através de correlação com a resistência elétrica. A resistência elétrica é correlacionada com a sucção por uma equação de calibração desenvolvida por Shock et al. (1998), a qual é utilizada pela fabricante como calibração padrão ou de fábrica. Seu intervalo de medida é considerado relativamente elevado, quando comparado com os tensiômetros e os blocos porosos de gesso, compreendendo o intervalo entre $0 \mathrm{e}$ $239 \mathrm{kPa}$. As medições foram realizadas in situ uma vez a cada semana, de abril a dezembro (outono e primavera), através de um logger manual.

Por fim, foi necessário coletarem-se amostras de solo ao redor do sensor $\mathrm{K}$ para verificar, através da curva característica obtida em laboratório, se os valores de umidade gravimétrica obtidos correspondiam aos valores de sucção matricial aferidos em campo, analisando-se tanto a acurácia dos sensores, quanto a condição de saturação do solo. Além disso, coletaram-se também amostras de sublastro granular (BGS) em diferentes pontos sobre o local onde o mesmo sensor havia sido instalado, com o intuito de se observar a sua condição de saturação, considerando-se que uma parte do sensor se encontrava em contato com o mesmo, enquanto que a outra estava em contato com o solo. O processo de coleta está presente na Figura 49.

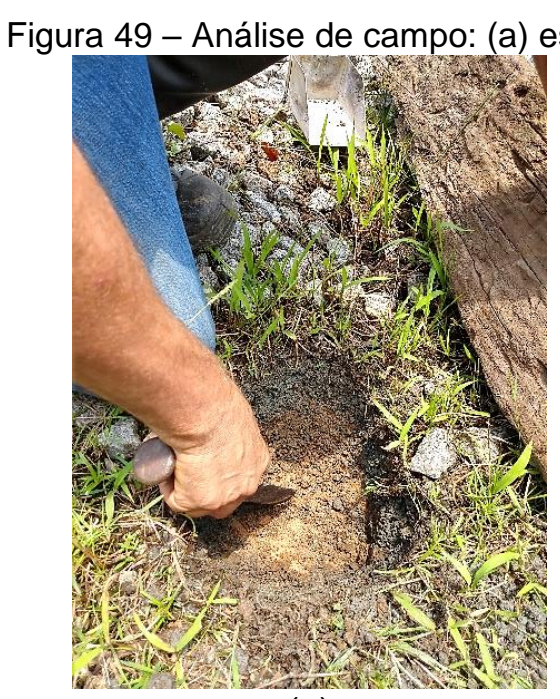

(a)

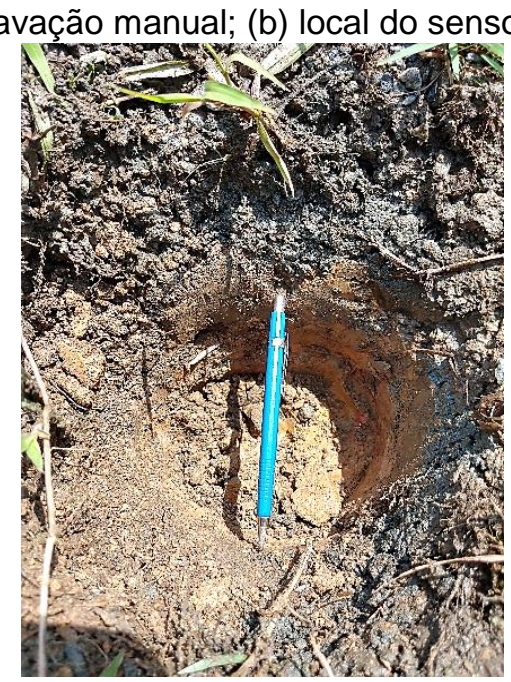

(b)

Por fim, ressalta-se que, antes da instrumentação, um ponto nas adjacências da via permanente foi perfurado com um trado manual, a $5 \mathrm{~m}$ de profundidade, com o intuito de se verificar a presença do nível freático. 


\section{5 - Modelagem numérica de infiltração da água pluvial na via férrea}

\subsection{1 - Geometria e componentes}

O modelo ferroviário desenvolvido neste trabalho, o qual objetivou simular a dinâmica da água pluvial incidente na via férrea (lastro, sublastro e subleito) para as condições climáticas reais de campo, representa uma estrutura bidimensional composta por 2230 elementos e 1585 nós, largura de 7,5 m e declividade transversal de 4\%. Essa declividade foi considerada, com base nos trabalhos de Cardoso et al. (2012), Ferreira et al. (2011), Ferreira e Teixeira (2012), Rushton e Ghataora (2012, 2014), que utilizaram inclinações de 4 e $5 \%$ em ferrovias europeias, e Nabais (2014), que sugere $4 \%$ de inclinação para ferrovias brasileiras.

A largura utilizada se baseou no trabalho de Costa (2016), o qual afirma que as cargas provenientes do material rodante não influenciam nos pontos localizados além dessa distância, mesmo não se considerando uma análise mecânica no modelo. A Figura 50 apresenta as características de malha e as condições geométricas adotadas no modelo.

Figura 50 - Geometria e malha das camadas da via permanente representadas pelo MEF

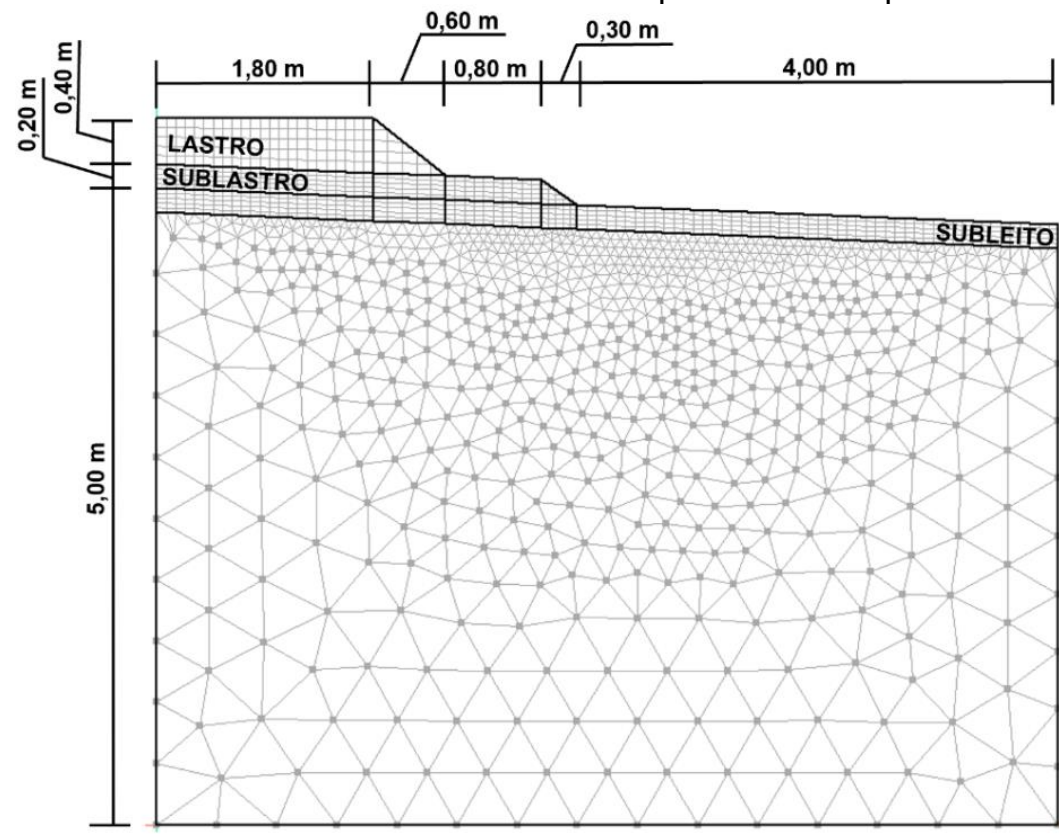

As camadas de superfície, as quais possuem grade de quadrículos com 0,08 m de largura e 0,05 m de altura, foram utilizadas nas camadas de lastro, sublastro e subleito 
para a computação numérica dos cálculos da interação entre o clima e os materiais da via. A dimensão do elemento triangular utilizados no subleito, logo abaixo da camada superficial, foi ajustada com uma dimensão de $0,50 \mathrm{~m}$. O critério de convergência adotado se baseou na diferença mínima entre resultados consecutivos $(0,005 \mathrm{~m})$ e dígitos significativos ( $\mathrm{DS}=2)$. Nota-se que a malha triangular do subleito ao se aproximar da camada de superfície, tende a igualar-se em dimensões dos quadrículos da camada de superfície. Sabendo-se que quanto maior o modelo numérico, maior será a análise e o tempo computacional para geração de dados e maior será a probabilidade de haver problemas de convergência, somente a metade do perfil da via férrea foi considerado.

Desse modo, o modelo é composto por três partes (de baixo para cima): (1) aterro compactado representando o subleito com $5 \mathrm{~m}$ de profundidade; (2) camada de sublastro granular de brita graduada simples com 0,20 m de espessura, considerandose as variações de espessura no campo (10 a $20 \mathrm{~cm}$ ); (3) camada de lastro com espessura de $0,40 \mathrm{~m}$. A profundidade do aterro adotada levou em consideração o limite de perfuração realizada in situ, após não ter sido observado o lençol freático naquele ponto. Além disso, foram considerados diferentes cenários com relação ao subleito, variando-se a sua curva característica, de sublastro granular, este último da seguinte forma: (i) variação da sua espessura; (ii) variação da sua extensão lateral; (iii) condição sem sublastro; e (iv) variação da sua permeabilidade. Com relação à camada de lastro, foram realizadas análises com e sem ela, com a finalidade de comparação e verificação da sua influência nos resultados de sucção no subleito, pois como já foi dito, quanto maior o modelo maiores serão o tempo computacional e os possíveis problemas de convergência.

\subsection{2 - Condições de contorno}

No modelo, a sua superfície pode ser exposta a eventos climáticos, tais como precipitação, evapotranspiração potencial, umidade relativa, temperatura, radiação solar, vegetação e neve, de tal forma a representar a complexa interação via-clima. No presente trabalho, considerando-se a realização de análises de fluxo transiente, as variações climáticas foram simuladas para dois anos consecutivos (2016-2017) e 
em 3 anos, este último levando em consideração somente os dados do ano de 2016, a partir de imposição de eventos de precipitação e de evaporação reais diários. $\mathrm{Na}$ Figura 51, as condições de contorno são apresentadas.

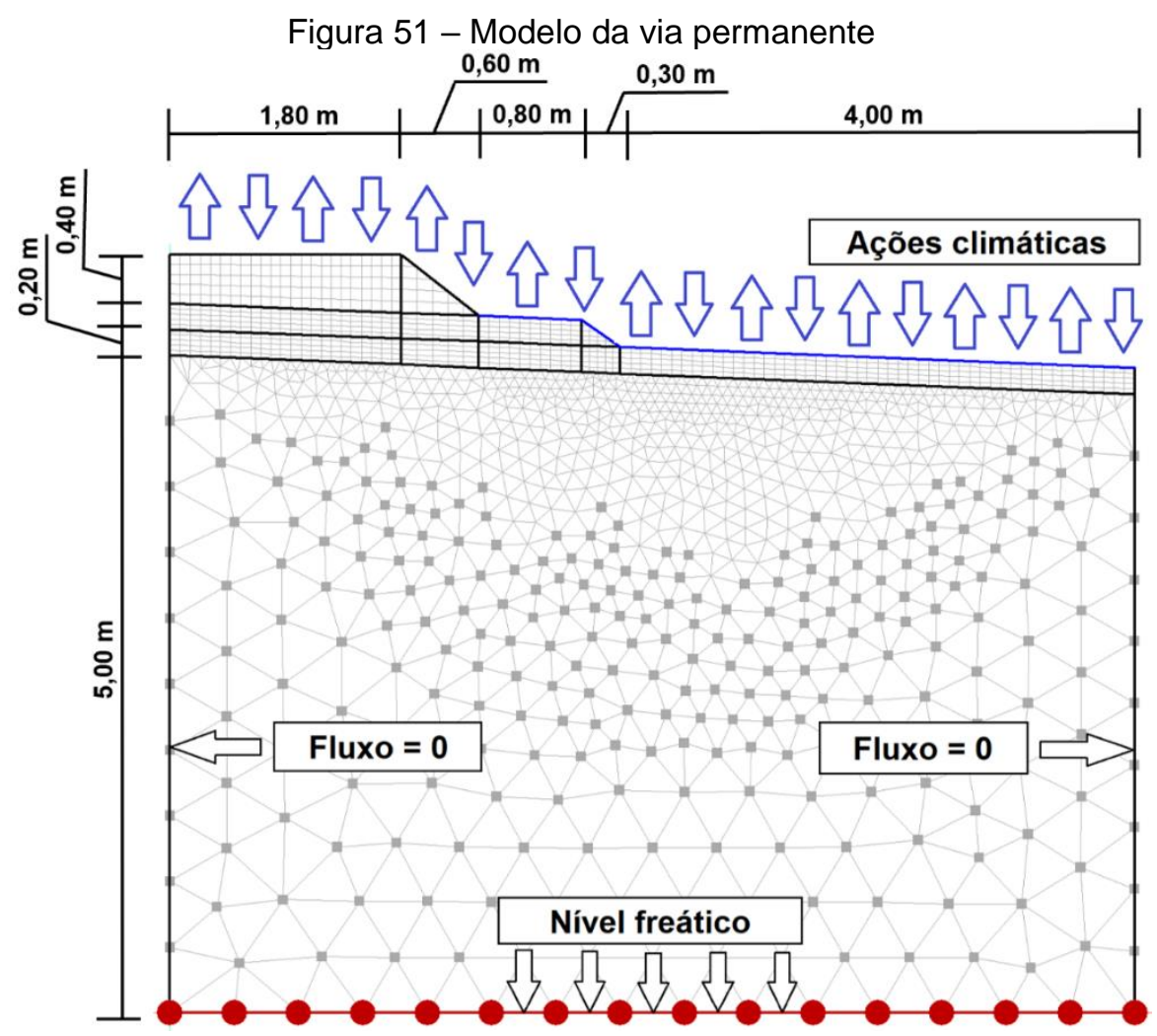

No modelo desenvolvido, a infiltração de água simulada pela condição de contorno solo-clima aplicada na superfície do modelo, é governada e calculada pela equação de balanço hídrico, representada pela Equação (26).

$$
\left(q_{P}+q_{M}\right) \cos \alpha+q_{E}+q_{R}=q_{I}
$$

Onde:

$q_{I}-$ infiltração;

$q_{R}$ - escoamento superficial ou runoff;

$q_{E}$ - evaporação;

$q_{P}$ - precipitação;

$q_{M}$ - degelo;

$\alpha_{e}$ - ângulo de inclinação do aterro. 
A infiltração gerada pela precipitação foi simulada através de três perspectivas. Se a intensidade da chuva é menor do que a infiltrabilidade mínima do solo na superfície, toda a água proveniente da chuva infiltrará no solo $\left(\mathrm{K}_{<} \mathrm{k}_{\mathrm{sat}}\right)$. Quando a taxa de precipitação é constante, a infiltração também é constante. Por fim, quando ela for maior do que a capacidade de infiltração do solo ( $\mid>k_{s a t}$ ), uma parte infiltra no solo, enquanto a outra, é convertida em escoamento superficial. Assim, a quantidade de escoamento superficial (runoff) é calculada no final do time step - intervalo de tempo determinado para cada análise - quando a poropressão é admitida igual a zero (estado saturado) e, então, a infiltração aplicada resulta em "poças d'água" ou acúmulo de água (Equação 27).

$$
q_{R}=q_{I}^{s i m}-\left(q_{P}+q_{M}\right) \cos \alpha-q_{E}
$$

Onde:

$q_{I}^{\text {sim }}$ - fluxo de infiltração simulada.

A evapotranspiração potencial (PET) computada pelo modelo, é dividida entre evaporação potencial (PE) e transpiração potencial (PT). Esta última é baseada na fração cobertura do solo (SCF) ou vegetação. Como nesse trabalho não foi considerada nenhum tipo de cobertura vegetal, a evapotranspiração potencial foi totalmente convertida em evaporação potencial (Equações 28 e 29). Além disso, assumiu-se neste trabalho, que a evaporação só é computada quando não ocorrem eventos de chuva.

$$
\begin{gathered}
q_{P E}=q_{P E T}(1-S C F) \\
q_{P T}=q_{P E T}(S C F)
\end{gathered}
$$

Onde:

$q_{P E}$ - evaporação potencial;

$q_{P E T}-$ evapotranspiração potencial;

$\mathrm{q}_{P T}$ - transpiração potencial;

$S C F$ - fração de cobertura vegetal do solo. 
Porém, para a modelagem do fluxo evaporativo na superfície do solo, deve-se ter o conhecimento dos dados de evaporação real. Rianna et al. (2014) consideram dois estágios para o cálculo computacional do processo físico de evaporação no solo, após o mesmo ter sido umedecido.

No primeiro, o solo atende à demanda evaporativa do clima, ou seja, o solo sempre possui água disponível no interior dos seus poros para evaporar (condição saturada), igualando-se os valores de evaporação potencial e real (evaporação efetiva = evaporação real/evaporação potencial $=1$ ). No segundo, a água presente no interior do solo é limitada, de tal modo, que o mesmo não consegue suprir a demanda evaporativa climática, iniciando-se a sua dessaturação e a redução da sua condutividade hidráulica, provocando a diminuição da evaporação efetiva (condição não saturada).

Desse modo, a partir dos dados diários de evaporação potencial obtidos pelo Instituto Nacional de Pesquisas Espaciais (INPE) para a região da Baixada Santista, utilizouse a Equação 30, proposta por Wilson et al. (1997), para o cálculo e obtenção da evaporação real diária na superfície do modelo.

$$
q_{A E}=q_{P E}\left(\frac{\exp \left(\frac{\psi g W_{v}}{R T}\right)-h_{a}}{1-h_{a}}\right)
$$

Onde:

$q_{A E}$ - evaporação real;

$q_{P E}$ - evaporação potencial;

$\psi$ - sucção matricial;

$W_{v}$ - massa molecular da água;

$R$ - constante universal dos gases;

$T$ - temperatura absoluta;

$h_{a}$ - umidade relativa do ar. 
Como o modelo proposto por Wilson et al. (1997) considera a umidade relativa do ar assim como o mesmo valor de temperatura para o solo, água e ar, foi necessário se obter tais dados através do Meteorological Aerodrome Report (METAR).

Referente ao nível do lençol freático, sua condição de contorno inicial foi referenciada e aplicada na extremidade inferior ou base do modelo, onde foi adotada constância no seu valor durante as simulações. Assim, foram simulados diferentes cenários iniciais com relação à profundidade do lençol freático (distância referente à superfície): (i) $2 \mathrm{~m}$; (ii) $5 \mathrm{~m}$; e (iii) $8 \mathrm{~m}$. Para tanto, aplicaram-se diferentes valores de carga de pressão total $(\mathrm{u})$ na base do modelo (destacado em vermelho na Figura 51), de acordo com a teoria de Bernoulli (Equação 29).

$$
h=\frac{u}{\rho_{w}}+y
$$

Onde:

$u=$ poropressão ou pressão neutra;

$\rho_{w}=$ massa específica da água;

$y=$ elevação.

Para a representação do nível freático a $2 \mathrm{~m}$ da superfície ( $3 \mathrm{~m}$ da base), admitiu-se que o valor da carga de pressão total na base do modelo seria $\mathrm{u}=3 \mathrm{~m}$, ou seja, uma carga de água de $3 \mathrm{~m}$ no local da condição de contorno. Com relação aos limites laterais, estes foram considerados impermeáveis (fluxo $=0$ ). Por isso, variou-se a sua extensão lateral do modelo, a fim de verificar se o seu tamanho influenciaria nos resultados.

Por fim, as análises tiveram como foco principal a camada de subleito nos seguintes locais: (i) na superfície e nas suas proximidades (abaixo e ao lado da via), onde as transferências de massa entre o clima e a via são de maior intensidade; e (ii) em profundidade (de um em um metro), objetivando-se verificar o comportamento hidráulico e o perfil de sucção/infiltração em todo o perfil transversal do subleito em função das ações climáticas e do nível freático. A Figura 52 apresenta as coordenadas dos pontos do subleito analisados no campo e no modelo numérico. 
Figura 52 - Localização do nível freático e dos pontos analisados

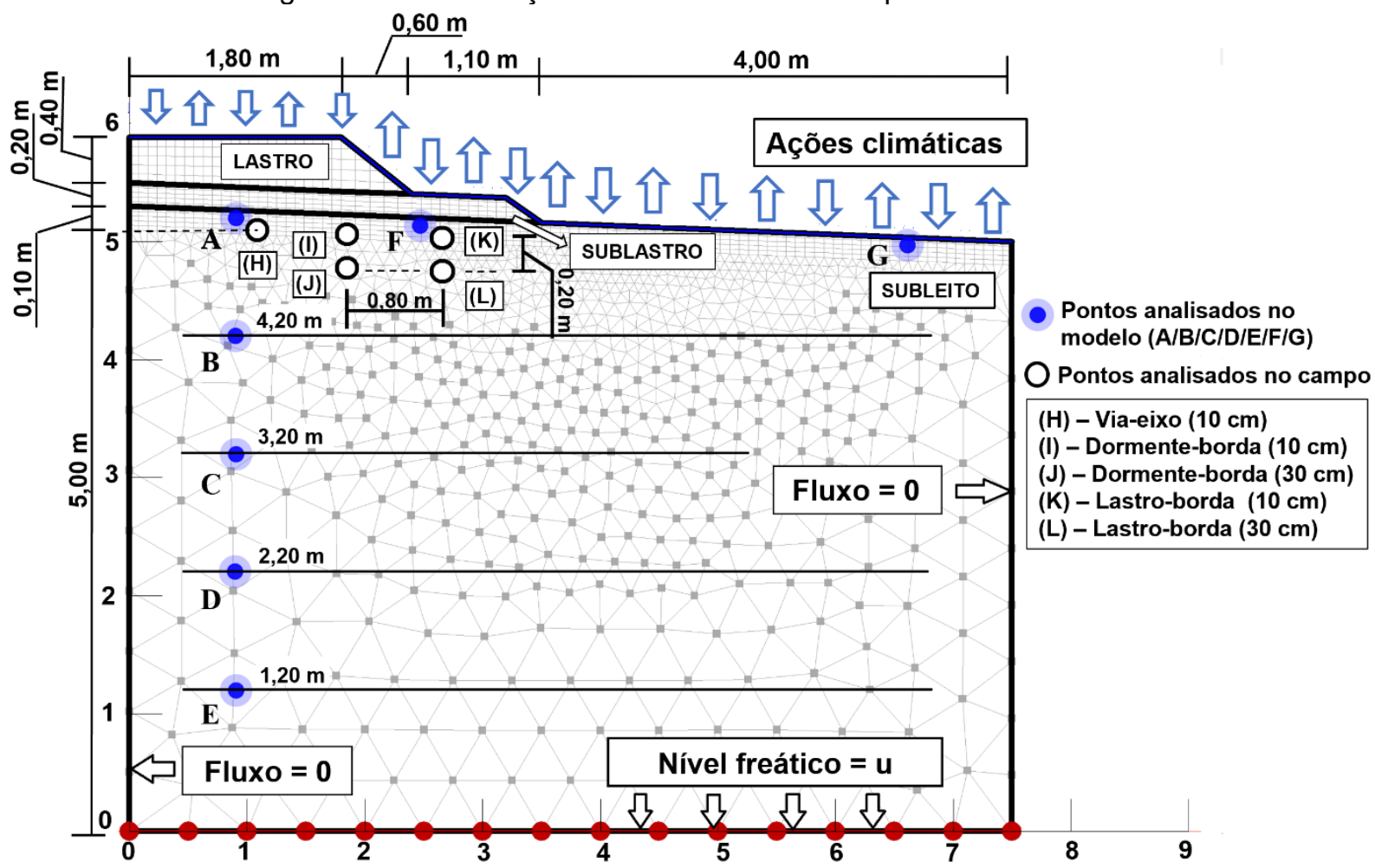

\section{Dados climáticos de Santos (Baixada Santista)}

Dados diários de precipitação, umidade relativa, temperatura e evaporação potencial, para a região onde o trecho está localizado para 2016/2017 de janeiro a dezembro, foram obtidos através do Instituto Nacional de Pesquisas Espaciais (INPE) e do Meteorological Aerodrome Report (METAR) e utilizados no modelo (Figuras 53 e 54).

Figura 53 - Precipitação, evaporação potencial e temperatura diárias de 2016 a 2017 na Baixada Santista

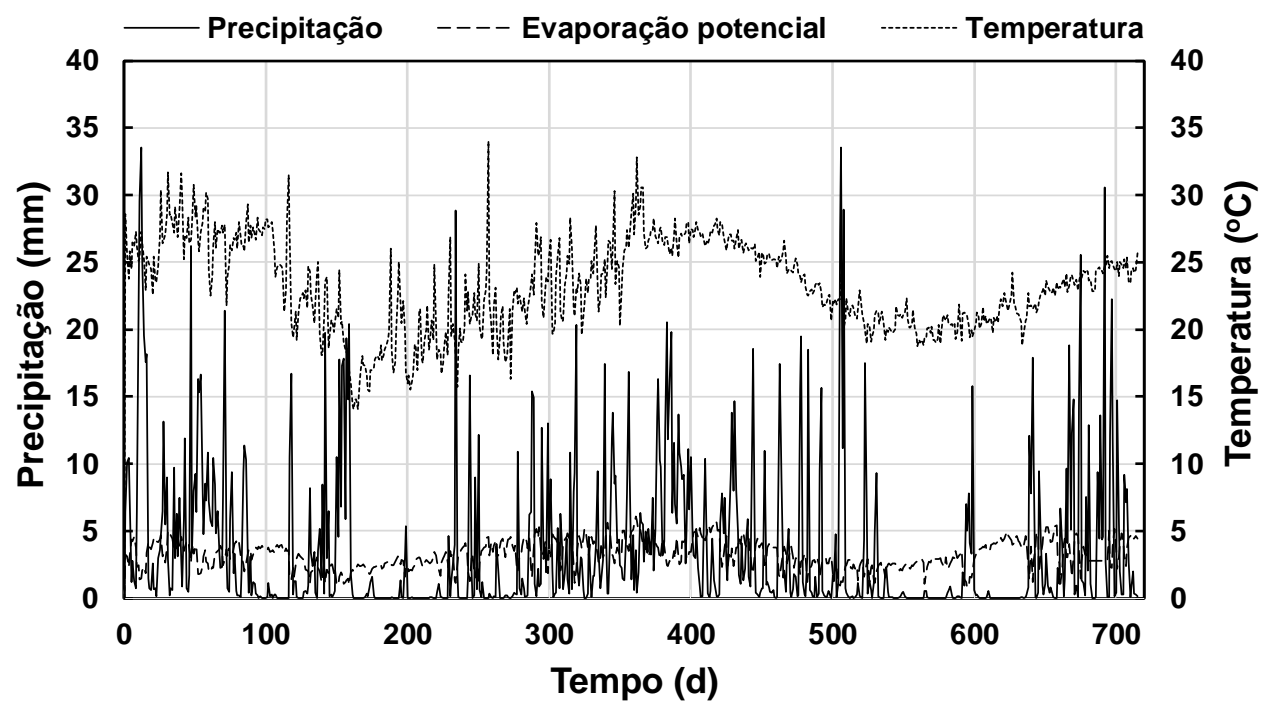


Figura 54 - Umidade relativa do ar diária de 2016 a 2017 em Santos

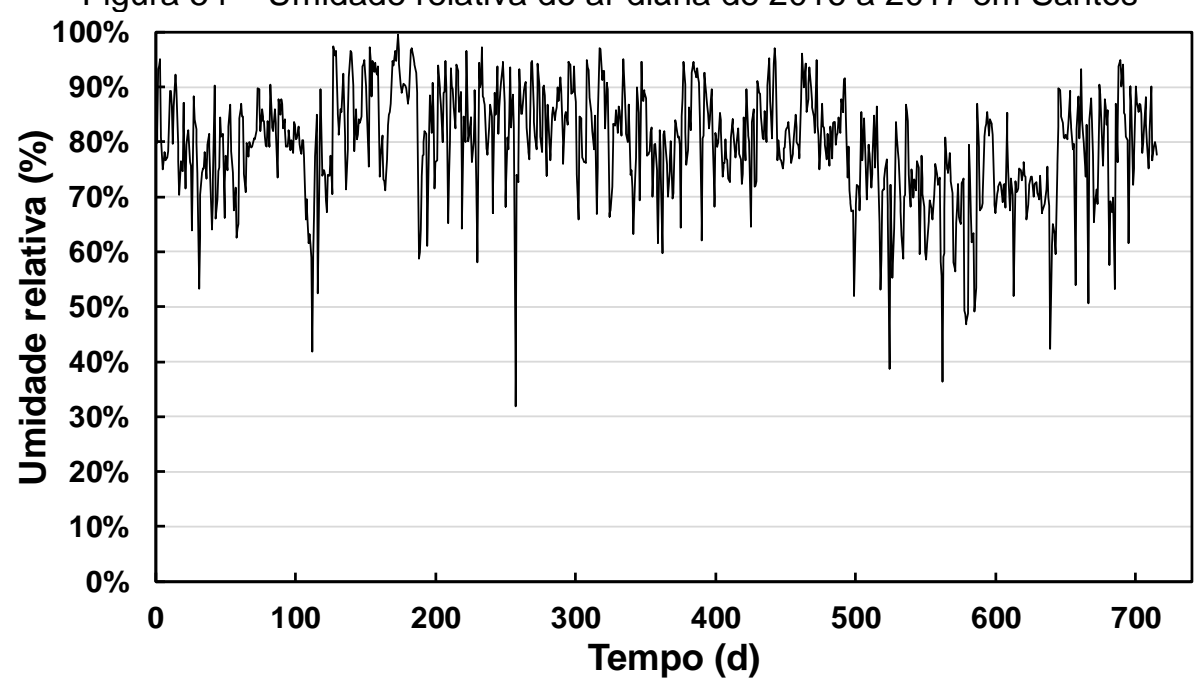




\section{4- RESULTADOS E DISCUSSÕES}

\section{1 - Ensaios laboratoriais}

\subsection{1 - Caracterização física dos materiais da via permanente}

\section{$\underline{\text { Subleito }}$}

A Figura 55 apresenta a distribuição granulométrica do material de solo coletado do subleito da via permanente, a qual evidencia a presença de $6 \%$ de pedregulho, $29 \%$ de areia, $53,5 \%$ de silte e $12,7 \%$ de argila, sendo classificada por uma curva de granulometria contínua densa ou curva bem graduada.

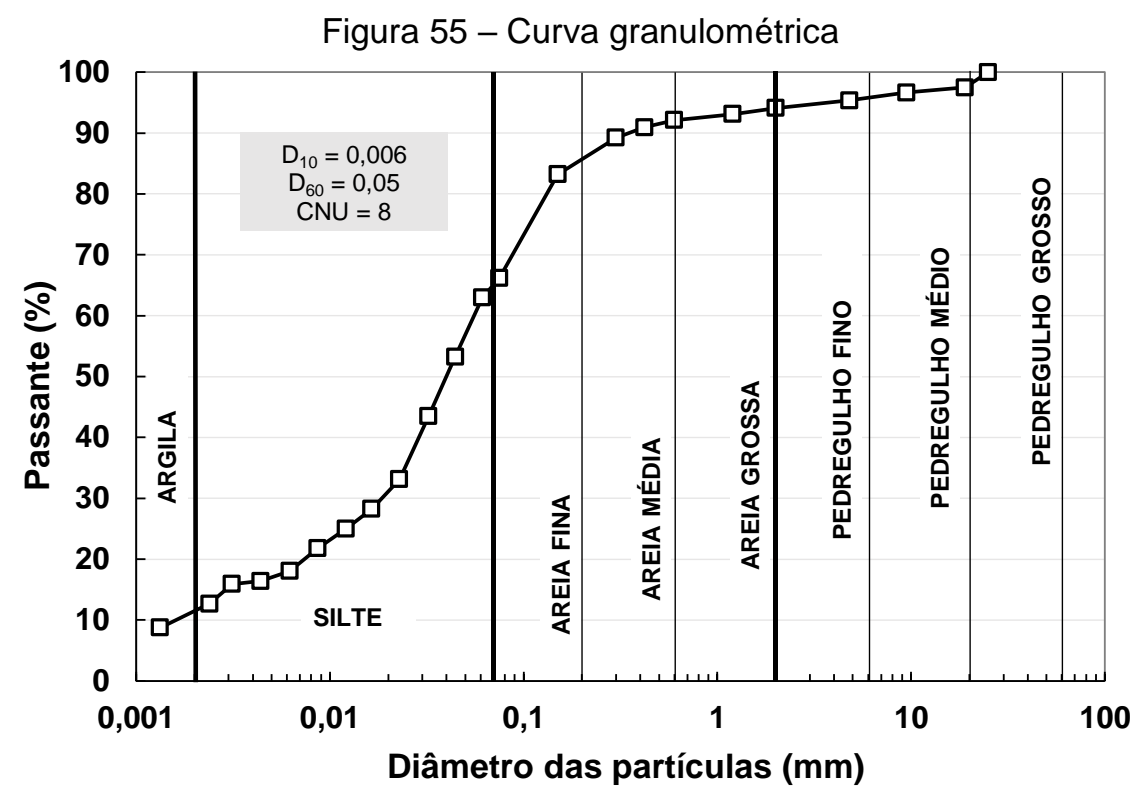

No que se refere ao resultado do ensaio de compactação do solo, foram obtidos valores de massa específica aparente seca e umidade ótima de 1,670 g/cm ${ }^{3}$ e 18,1\%, respectivamente.

Após a realização dos ensaios para a obtenção dos índices de consistência, limite de liquidez (LL) e limite de plasticidade (LP), obtiveram-se como resultados valores correspondentes a $32 \%$ e $27 \%$, respectivamente. Assim, o IP foi de $5 \%$, considerado um solo mediamente plástico, de acordo com a literatura. A densidade real dos grãos obtida pelo ensaio do picnômetro teve como resultado 2,68 . 
A partir dos resultados de granulometria e índices de consistência, o solo foi classificado como solo siltoso inorgânico ou orgânico de baixa compressibilidade (ML ou OL), de acordo com o SUCS, o que coincide com a classificação preliminar realizada como também com a HRB.

Preliminarmente, o material apresentou baixa resistência a seco, reação de média a rápida, e elevada tendência de deterioração antes do alcance do LP (baixa rigidez ou dureza), o que se caracteriza um solo siltoso. Pela classificação HRB o material foi classificado por silte arenoso não plástico ou moderadamente plástico de baixa estabilidade (A-4) com permeabilidade média entre $10^{-3}$ a $10^{-6} \mathrm{~cm} / \mathrm{s}$, possuindo um índice de grupo (IG) de 7. Quanto mais próximo o IG do valor 0 , melhor a qualidade do material para a pavimentação. Desse modo, de acordo com os métodos tradicionais mencionados, este solo é de baixa qualidade para aplicação na estrutura de pavimentos.

Para verificar a qualidade do solo com mais precisão, considerando-se a sua peculiaridade tropical, o ensaio MCT apresentou os seguintes valores dos parâmetros M-MCV (Tabela 3): (i) c' $c^{\prime}=1,48$; (ii) d' $=1,89$; (iii) e' $=2,37$; e (iv) $\mathrm{Pi}=275 \%$. A partir de tais parâmetros, foi possível classificar o solo como NS' ou solo saprolítico siltoarenoso, que corresponde à mesma classificação SUCS e HRB, pelo fato de o mesmo não ser laterítico, não havendo confrontamento entre elas. De acordo com o monitoramento realizado por Nogami e Villibor (1995) no estado de São Paulo, não há presença de solo laterítico no local onde este trabalho se baseia.

Segundo Nogami e Villibor (1995), este solo é peculiarmente tropical resultante do intemperismo local, de constituição predominantemente feldspática-micáceaquartzosa. Suas características mecânicas e hidráulicas, quando compactado na umidade ótima e massa específica aparente seca máxima, se resumem em baixa capacidade de suporte e baixo módulo de resiliência quando imersos em água; elevada erodibilidade; expansibilidade (e') alta; e permeabilidade média.

Por fim, foi realizado o ensaio expedito de classificação do solo, obtendo-se assim os seguintes parâmetros: (i) contração $=0,57 \mathrm{~mm}$; e (ii) penetração $=5 \mathrm{~mm}$. Assim, o 
solo foi classificado como solo não-laterítico siltoso e arenoso (NS'/NA'), de elevada expansibilidade e penetração, ao elevar-se seu grau de saturação.

Com o intuito de se avaliar o comportamento do solo de modo mais aprofundado, foi realizado ensaio de caracterização mineralógica através da difratometria de Raio-X. O estudo foi realizado através do método do pó. A identificação das fases cristalinas, abaixo discriminadas, foi obtida por comparação do difratograma da amostra com os bancos de dados PDF2 do ICDD - International Centre for Diffraction Data e ICSD Inorganic Crystal Structure Database. Segundo Alves (2018), dentre os compostos minerais encontrados, podem ser destacados o quartzo $\left(\mathrm{SiO}_{2}\right)$, caulinita $\left(\mathrm{Al}_{2} \mathrm{Si}_{2} \mathrm{O}_{5}(\mathrm{OH})_{4}\right)$, muscovita $\left(\mathrm{KAl}_{2}\left(\mathrm{Si}_{3} \mathrm{Al}\right) \mathrm{O}_{10}(\mathrm{OH}, \mathrm{F})_{2}\right)$, microclínio $\left(\mathrm{KASi}_{3} \mathrm{O}_{8}\right)$, rectorita $\left(\mathrm{K}_{1,2} \mathrm{Al} 4 \mathrm{Si}_{8} \mathrm{O}_{20}(\mathrm{OH})_{4} 4 \mathrm{H}_{2} \mathrm{O}\right)$, gibsita $\quad(\mathrm{AIOH})_{3}$, zeólita $\quad(\mathrm{AlPO} 4)$ e anfibólio $\left(\mathrm{Al}_{3,2} \mathrm{Ca}_{3,4} \mathrm{Fe}_{4,02} \mathrm{~K}_{0,6} \mathrm{Mg}_{6} \mathrm{NaSi}_{12,8} \mathrm{O}_{44}(\mathrm{OH})_{4}\right)$.

Verificou-se a presença do argilomineral caulinita no solo, considerado mais estável quando comparado com a ilita e a montimorilonita, em decorrência da sua baixa atividade. Além disso, as forças entre suas folhas (maior arranjo estrutural do átomo que se repete formando os argilominerais) são fortes pois resultam provavelmente de ligações de $\mathrm{H}$ e de forças de valência secundária, dificultando a troca catiônica e, consequentemente, tornando-se um material menos expansivo.

Embora exista um argilomineral estável como a caulinita nesse tipo de solo, este possui considerável expansibilidade quando em contato com a água, provavelmente em decorrência da presença de outros minerais presentes, como a muscovita (mica) e a rectorita (esmectita), os quais pertencem ao grupo da montmorilonita.

Esse grupo é, no geral, caracterizado por minerais menos estáveis, devido a elevada capacidade de troca catiônica e superfície específica quando comparado ao grupo da caulinita, contribuindo para que íons hidratados sejam facilmente atraídos, assim ocasionando a expansão do solo ou um comportamento fragilizado na presença de água. Além disso, a existência de quartzo explica a característica arenosa do material, com baixa plasticidade, tornando-se um material de difícil manuseio e moldagem 
durante os ensaios, conforme foi observado. A Tabela 3 apresenta o resumo das propriedades físicas e as classificações do material de solo estudado.

Tabela 3 - Resumo das propriedades físicas e classificação do solo

\begin{tabular}{ccccccccccccc}
\hline Material & $\begin{array}{c}\text { LL } \\
(\%)\end{array}$ & $\begin{array}{c}\text { LP } \\
(\%)\end{array}$ & $\begin{array}{c}\text { Areia } \\
(\%)\end{array}$ & $\begin{array}{c}\text { Silte } \\
(\%)\end{array}$ & $\begin{array}{c}\text { Argila } \\
(\%)\end{array}$ & $\begin{array}{c}\gamma_{\text {dmax }} \\
\left(\mathbf{g}^{\prime} \mathbf{c m}^{3}\right)\end{array}$ & $\begin{array}{l}\mathbf{w}_{\text {ot. }} \\
(\%)\end{array}$ & $\mathbf{G}_{\mathbf{s}}$ & HRB & SUCS & MCT & $\begin{array}{c}\text { Classificação } \\
\text { expedita }\end{array}$ \\
\hline Subleito & 32 & 27 & 29 & 53,5 & 12,7 & 1,670 & 18,1 & 2,68 & A-4 & ML or OL & NS' & NS'/NA' \\
\hline
\end{tabular}

\section{$\underline{\text { Sublastro }}$}

A Figura 56 apresenta a granulometria do sublastro granular aplicado em campo, o qual respeita a Faixa $\mathrm{C}$, e a de um sublastro qualquer compatível com a Faixa B, ambos da mesma especificação DERSA ET-P0/005.

Figura 56 - Granulometria do sublastro granular de campo na faixa C e de uma BGS na faixa B

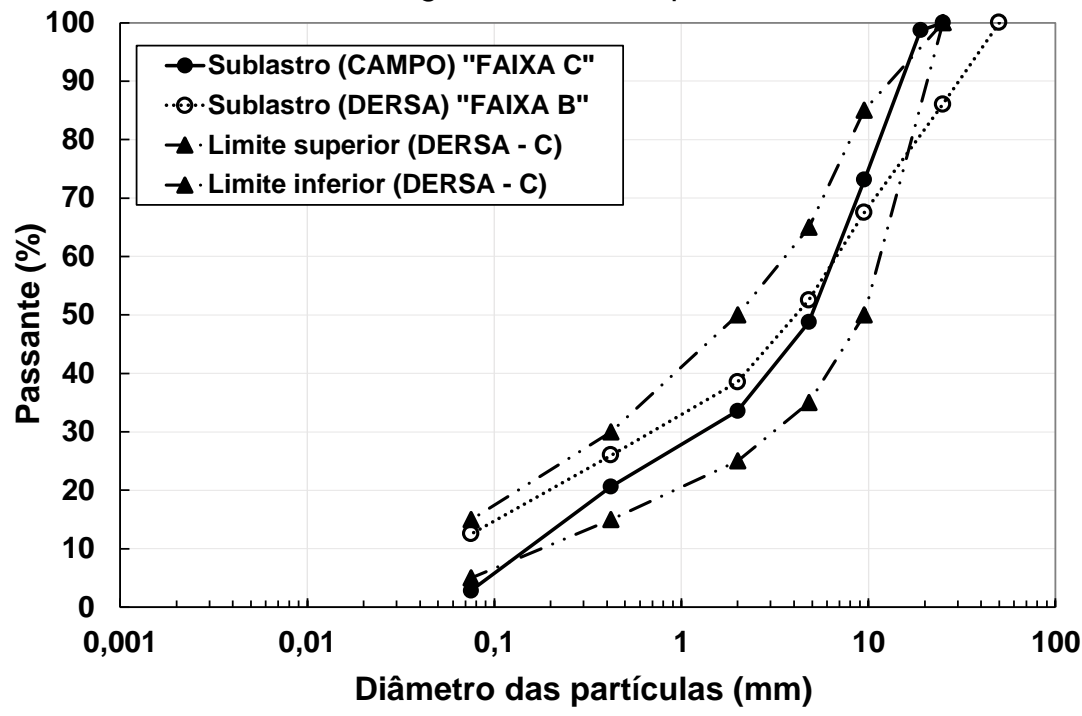

Verificou-se que ambas as curvas granulométricas são próximas, porém a Faixa B é mais bem graduada, enquanto que a Faixa $\mathrm{C}$ é mais uniforme, ou seja, este último caso possui uma menor quantidade de partículas de menor tamanho, o que afeta o arranjo dos grãos e facilita o seu entrosamento.

Sabe-se que o tamanho dos grãos influencia no coeficiente de permeabilidade de materiais granulares. Assim, ressalta-se a importância do diâmetro efetivo (D10) e do coeficiente de não uniformidade (CNU) desses materiais. 
De acordo com os resultados do ensaio de compactação, verificou-se que o sublastro granular de campo possui umidade ótima de 4,4\% e densidade aparente seca máxima de $2,259 \mathrm{~g} / \mathrm{cm}^{3}$, em energia modificada, como exigido pela DERSA ET-DE-P00/008.

Alves (2018) realizou ensaios de compactação com o mesmo material deste trabalho, e verificou que o mesmo possui umidade ótima correspondente à $5,3 \%$ e densidade aparente seca máxima de $2,114 \mathrm{~g} / \mathrm{cm}^{3}$. Os resultados estão coerentes à medida que quando maior é a energia para a compactação de materiais granulares, menor será a sua umidade ótima e maior será sua densidade aparente seca máxima.

Virgiliis (2009) estudou a BGS compatível com os limites da FAIXA B, e encontrou valores de umidade ótima e densidade máxima de $6,5 \%$ e $2,170 \mathrm{~g} / \mathrm{cm}^{3}$, respectivamente. Como a Faixa $\mathrm{B}$ é mais bem graduada que a Faixa $\mathrm{C}$, materiais referentes a ela apresentará maior capacidade de retenção em decorrência da maior de quantidade de finos na amostra, e por isso, sua umidade ótima é maior que a da Faixa C, proporcionando uma menor densidade aparente seca.

A Tabela 4 exibe os índices físicos da BGS para as três condições, compactada nas energias modificada e normal, em diferentes faixas granulométricas, com o intuito de verificar as características físicas de cada situação e como elas podem influenciar no comportamento hidráulico de um subleito ferroviário.

Tabela 4 - Resumo das propriedades físicas do sublastro granular em três condições

\begin{tabular}{|c|c|c|c|c|c|c|c|c|c|c|c|}
\hline Material & $\begin{array}{c}\text { Rocha de } \\
\text { origem }\end{array}$ & $\begin{array}{c}\text { Energia de } \\
\text { compactação }\end{array}$ & $\eta$ & e & $\underset{\left(\mathrm{g} / \mathrm{cm}^{3}\right)}{\gamma_{\mathrm{s}}}$ & $\begin{array}{l}w_{\text {ot }} \\
(\%)\end{array}$ & $\underset{\left(\mathrm{g} / \mathrm{cm}^{3}\right)}{\gamma_{s}}$ & $\mathrm{G}_{\mathrm{s}}$ & $\begin{array}{l}\mathbf{w}_{\text {sat }} \\
(\%)\end{array}$ & $\begin{array}{l}\theta_{\text {sat }} \\
(\%)\end{array}$ & Autor \\
\hline $\begin{array}{c}\text { Sublastro granular } \\
\text { (BGS - Faixa B) }\end{array}$ & Granito & Modificada & 0,178 & 0,22 & 2,169 & 6,5 & 2,344 & 2,640 & 8,3 & 18,1 & $\begin{array}{l}\text { VIRGILIIS } \\
(2009)\end{array}$ \\
\hline \multirow{2}{*}{$\begin{array}{c}\text { Sublastro granular } \\
\text { (BGS - Faixa C) }\end{array}$} & Granito & Modificada & 0,167 & 0,20 & 2,249 & 4,4 & 2,377 & 2,700 & 7,4 & 16,7 & - \\
\hline & Granito & Normal & 0,217 & 0,28 & 2,114 & 5,3 & 2,440 & 2,700 & 10,3 & 21,7 & $\begin{array}{c}\text { ALVES } \\
(2018)\end{array}$ \\
\hline
\end{tabular}

A partir da tabela 4, verifica-se que, das três considerações, a mais susceptível a infiltração de água é a de Alves (2018), em decorrência da menor densidade máxima seca ocasionada pela energia normal, um maior índice de vazios e, consequentemente, porosidade mais elevada. Por outro lado, a BGS da faixa C 
demonstrou possuir maior densidade seca máxima e, consequentemente, menor porosidade, em decorrência da compactação na energia modificada. O material de BGS da faixa B, correspondente ao trabalho de Virgiliis (2009), apresentou valor de porosidade sensivelmente maior que a anterior, podendo assim ser considerada nas análises numéricas em substituição aos dados de campo.

\section{Lastro}

A Figura 57 e a Tabela 5 mostram os resultados da análise granulométrica do lastro aplicado no trecho experimental.

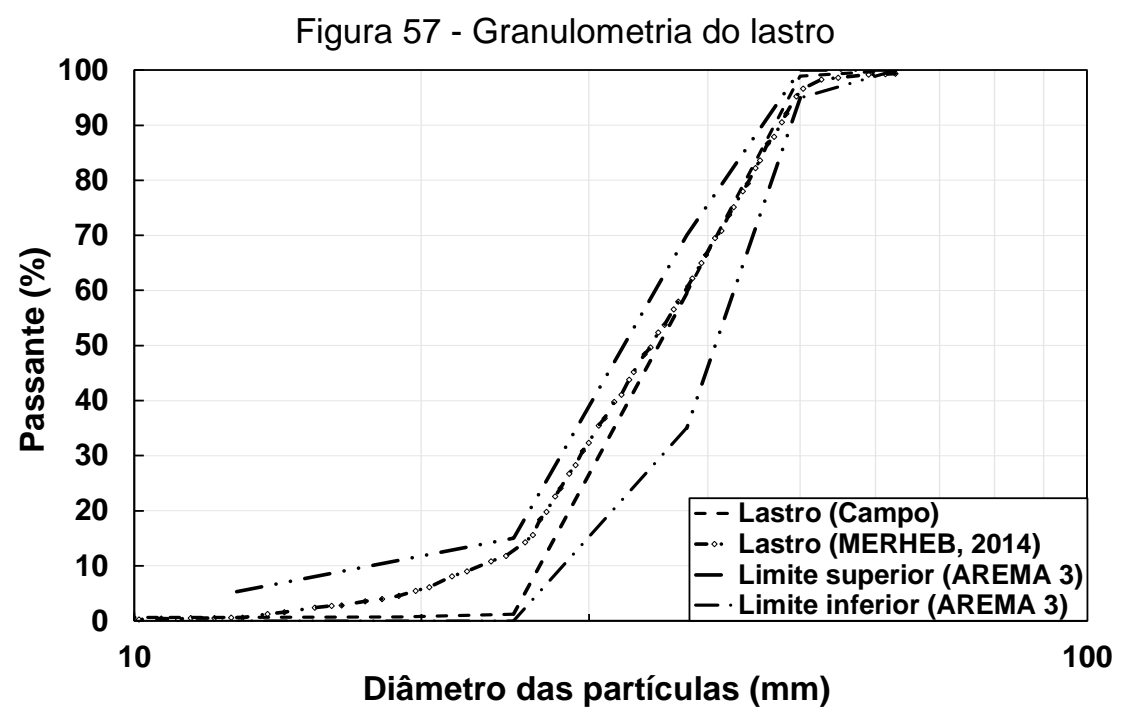

Tabela 5 - Análise granulométrica do lastro

\begin{tabular}{ccccc}
\hline Peneira - mm & $\begin{array}{c}\text { Passante (\%) } \\
\text { Campo }\end{array}$ & $\begin{array}{c}\text { Passante (\%) } \\
\text { (Merheb, 2014) }\end{array}$ & \multicolumn{2}{c}{ AREMA 3 } \\
\hline 63,00 & 100,0 & 100,00 & 100 & 100 \\
\hline 50,00 & 98,9 & 95,25 & 95 & 100 \\
\hline 38,00 & 59,5 & 57,98 & 35 & 70 \\
\hline 25,00 & 1,23 & 11,83 & 0 & 15 \\
\hline 12,50 & 0,64 & 0,52 & 0 & 5 \\
\hline
\end{tabular}

Com o intuito de tentar representá-lo no modelo numérico, dados de densidade aparente seca $\left(\gamma_{s}\right)$, porosidade $(\eta)$ e índice de vazios (e) do lastro foram obtidos a partir de Merheb (2014), após terem sido realizadas comparações com Wnek et al (2013) e Costa (2016). Esses trabalhos foram consultados com o objetivo de se encontrar uma situação que melhor representasse a condição de campo em termos 
de granulometria e índices físicos. Por fim, os dados de lastro obtidos em Merheb (2014) foram aplicados, devido às seguintes condições: mesma distribuição granulométrica (AREMA 3) e densidade elevada ${ }^{7}$ (condição estabilizada ou com menor índice de vazios). A granulometria e as propriedades do lastro utilizadas neste trabalho estão apresentadas pela Tabela 6.

Tabela 6 - Resultados dos índices físicos do lastro

\begin{tabular}{cccccccccc}
\hline Material & $\begin{array}{c}\text { Rocha de origem - } \\
\text { estado }\end{array}$ & $\mathbf{\eta}$ & $\mathbf{e}$ & $\begin{array}{c}\boldsymbol{\gamma}_{\mathbf{s}} \\
\left(\mathbf{g} / \mathbf{c m}^{3}\right)\end{array}$ & $\begin{array}{c}\mathbf{w}_{\text {ot }} \\
(\%)\end{array}$ & $\begin{array}{c}\gamma_{\text {sat }} \\
\left(\mathbf{g} / \mathbf{c m}^{3}\right)\end{array}$ & $\mathbf{G}_{\mathbf{s}}$ & $\begin{array}{c}\mathbf{w}_{\text {sat }} \\
(\%)\end{array}$ & $\begin{array}{c}\boldsymbol{\theta}_{\text {sat }} \\
(\%)\end{array}$ \\
\hline $\begin{array}{c}\text { Lastro com elevada } \\
\text { densificação }\left(>1.59 \mathrm{~g} / \mathrm{cm}^{3}\right)\end{array}$ & $\begin{array}{c}\text { Granito - } \\
\text { estabilizado }\end{array}$ & 0,40 & 0,66 & 1690 & - & 2,850 & 2,817 & 23,0 & 40,0 \\
\hline
\end{tabular}

\subsection{2 - Caracterização hidráulica dos materiais da via permanente}

\section{Subleito}

Foram utilizados três métodos para a determinação dos pontos experimentais da curva característica com histerese do solo e devido à duração e complexidade do ensaio para a sua aquisição, conforme comentado no item 3.2.2: (i) método 1; (ii) método 2; e (iii) método 3.

O método 2 adotado foi baseado na utilização de sensores de medição indireta da sucção, conhecido por Watermark, devidamente inseridos no solo, e do método do papel filtro. Verifica-se que, referente aos sensores Watermark, foi possível se obter uma curva bem definida, com valor de entrada de ar (VEA) correspondente à $30 \mathrm{kPa}$, característico de materiais siltosos, de acordo com Aubertin et al., 1998 apud Gerscovich, 2001.

Além disso, o grau de saturação alcançado no ensaio na fase de saturação, foi de $92 \%$, aproximadamente, considerado elevado. A continuação da curva se deu perfeitamente pelo método do papel filtro, podendo ser determinada a sução residual do solo. As Figuras 58 e 59 apresentam os pontos experimentais obtidos em laboratório e a curva de ajuste desses pontos, respectivamente, obtidos através

\footnotetext{
7 Segundo Wnek et al. (2013), um lastro com elevada densificação possui valores de massa específica maiores que $1,59 \mathrm{~g} / \mathrm{cm}^{3}$.
} 
desses instrumentos e a Tabela 7 apresenta as características de moldagem do corpo de prova (CP) moldado em cilindro Proctor grande e os parâmetros de ajuste.

Figura 58 - Curva característica do solo obtida pelo método 2 (umidade gravimétrica versus sucção)

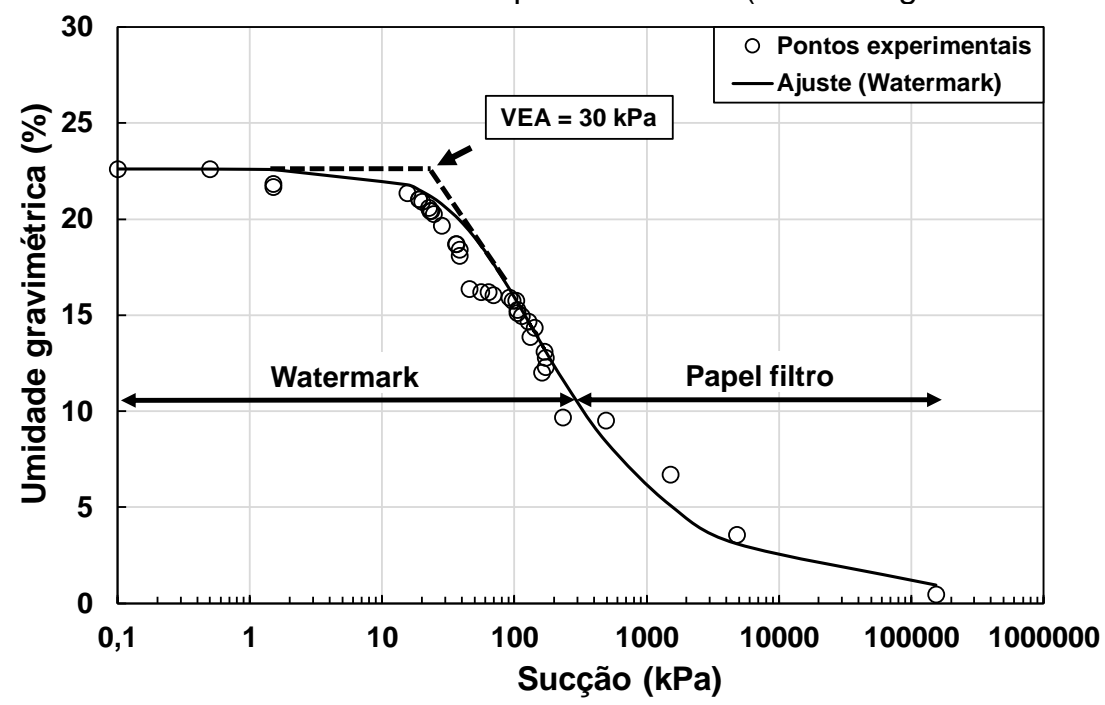

Figura 59 - Curva característica do solo obtida pelo método 2 (umidade volumétrica versus sucção)

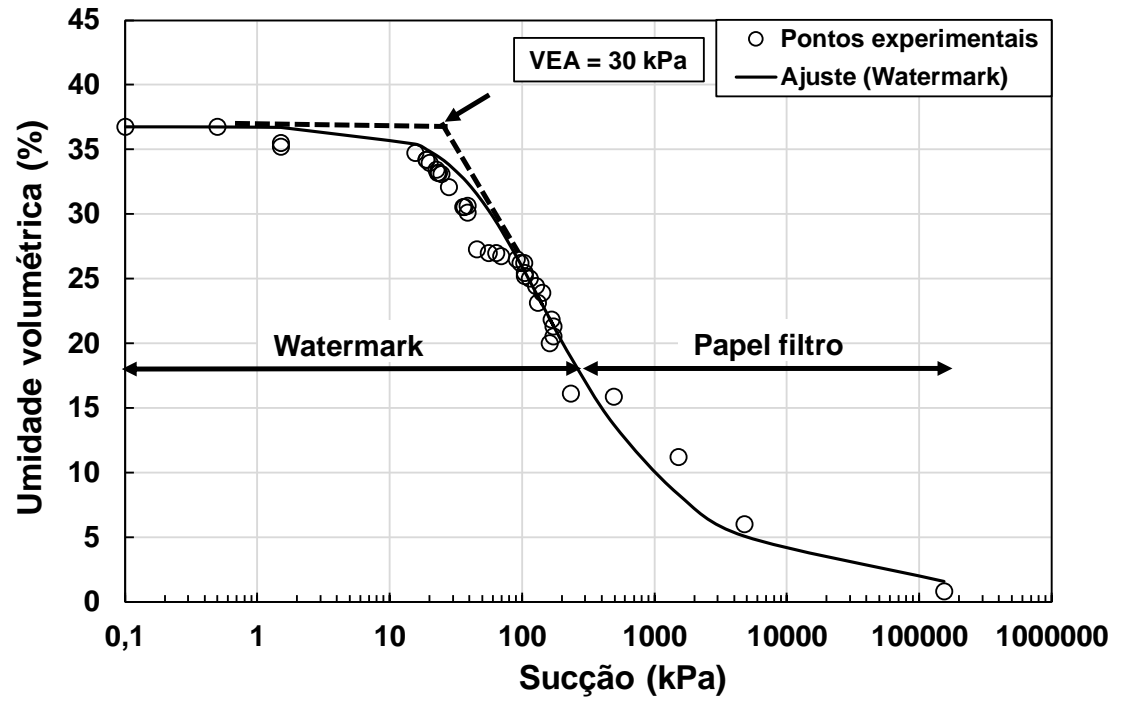

Tabela 7 - Características de moldagem e parâmetros de ajuste da curva característica (método 2)

\begin{tabular}{ccccccccc} 
Subleito & $\begin{array}{c}\text { VEA } \\
(\mathbf{k P a})\end{array}$ & $\boldsymbol{\theta}_{\mathbf{r}}$ & $\boldsymbol{\theta}_{\mathbf{s}}$ & $\boldsymbol{\alpha}$ & $\mathbf{n}$ & Erro & $\begin{array}{c}\gamma_{\mathbf{s}} \\
\left(\mathbf{g} / \mathrm{cm}^{3}\right)\end{array}$ & $\mathbf{w}(\%)$ \\
\hline $\mathrm{CP}$ & 30 & 0,01549 & 0,36750 & 0,0157 & 1,493 & 2,633 & 1,667 & 18,3 \\
\hline
\end{tabular}

O método 3, seguiu-se o mesmo princípio do método 2, porém com o sensor do tipo TEROS-21 e sem a utilização do papel filtro. A ausência do papel filtro se justificou pelo elevado intervalo de medição do sensor TEROS-21, compreendido entre $9 \mathrm{kPa}$ 
e 100.000 kPa de sucção. Assim, admitiu-se que o sensor seria capaz de determinar a curva característica completa do solo. Figuras 60 e 61 apresentam os pontos experimentais obtidos em laboratório e a curva de ajuste determinada para esses pontos, respectivamente, e a Tabela 8 apresenta as características de moldagem do corpo de prova (CP) moldado em cilindro Proctor pequeno, assim como os parâmetros de ajuste da curva.

Tabela 8 - Características de moldagem e parâmetros de ajuste da curva característica (método 3)

\begin{tabular}{ccccccccc} 
Subleito & $\begin{array}{c}\text { VEA } \\
(\mathbf{k P a})\end{array}$ & $\boldsymbol{\theta}_{\mathbf{r}}$ & $\boldsymbol{\theta}_{\mathbf{s}}$ & $\boldsymbol{\alpha}$ & $\mathbf{n}$ & Erro & $\begin{array}{c}\gamma_{\mathbf{s}} \\
\left(\mathbf{g} / \mathrm{cm}^{3}\right)\end{array}$ & $\mathbf{w}(\%)$ \\
\hline $\mathrm{CP}$ & 10 & 0,09036 & 0,36742 & 0,0475 & 1,2806 & 3,3706 & 1,633 & 17,9 \\
\hline
\end{tabular}

Figura 60 - Curva característica do solo obtida pelo método 3 (umidade gravimétrica versus sucção)

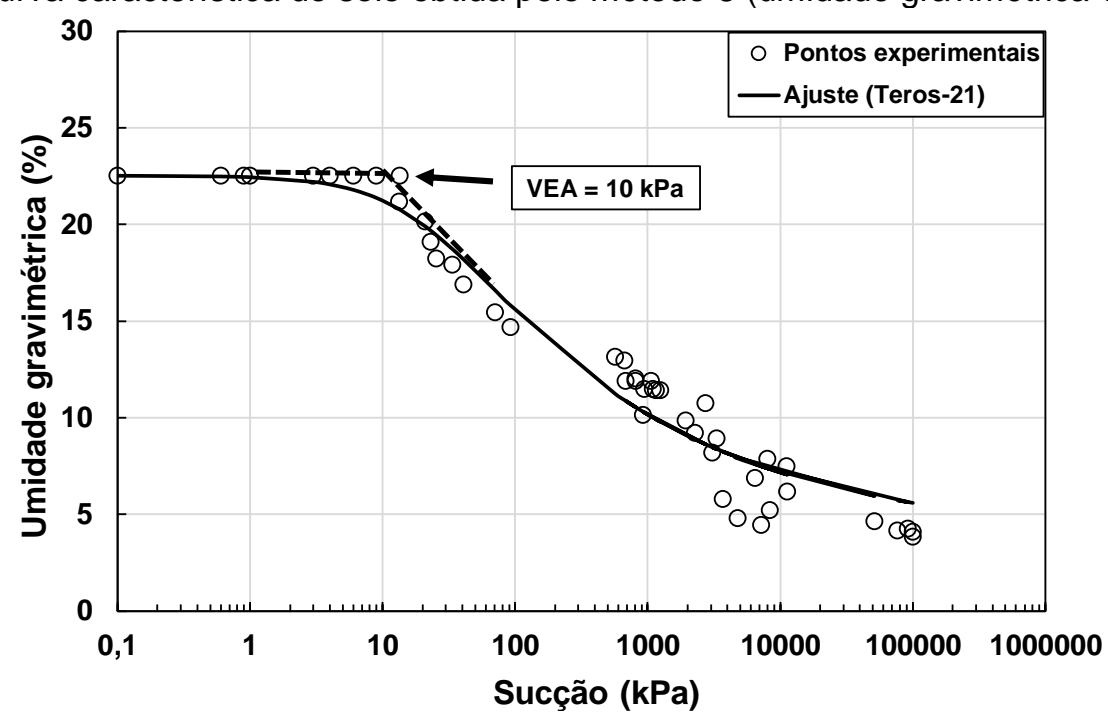

Figura 61 - Curva característica do solo obtida pelo método 3 (umidade volumétrica versus sucção)

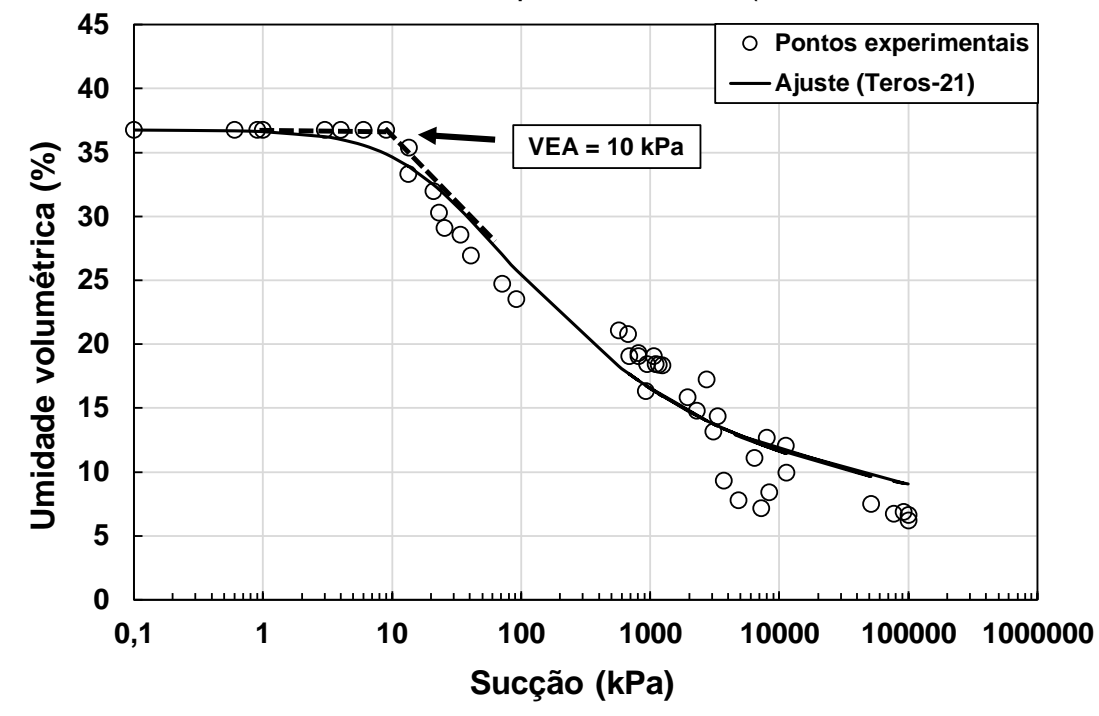


A partir dos dados experimentais, verificou-se que que o solo conseguiu alcançar uma umidade gravimétrica de 23\%, correspondente a $91 \%$ de grau de saturação, aproximadamente, próximo ao valor obtido pelo método anterior. Entretanto, o valor de entrada de ar obtido não condiz com o tipo de solo e com a curva anterior. Por fim, não foi possível a obtenção da curva característica do solo com histerese diante da tentativa de coleta dos dados experimentais através do processo de umedecimento, em função da imprecisão e falta de repetibilidade dos dados, dessa forma sendo considerado um método ineficiente para a determinação da curva característica do solo em laboratório. Ressalta-se que não foi realizada a calibração do sensor, considerando-se que o manual do fabricante garante a sua calibração de fábrica para diferentes tipos de solo, desde os mais finos até os mais grossos, devido à sua matriz porosa.

O método 1, considerado o método clássico na literatura e o mais lento, se baseia utilização da placa de sucção, placa de pressão e papel filtro. Apesar de duradouro, foi possível a determinação da curva característica do solo com histerese somente através dele, pois é possível se ter uma maior precisão e controle nos processos de umedecimento (aspersão de água), na medição de volume dos corpos de prova e na medição da sucção pelo papel filtro, considerado um método consagrado no estudo dos solos não saturados. As Figuras 62, 63, 64 e 65 apresentam os gráficos dos pontos obtidos experimentalmente e o seus respectivos ajustes.

Figura 62 - Curva característica do solo obtida pelo método 1 (umidade gravimétrica versus sucção)

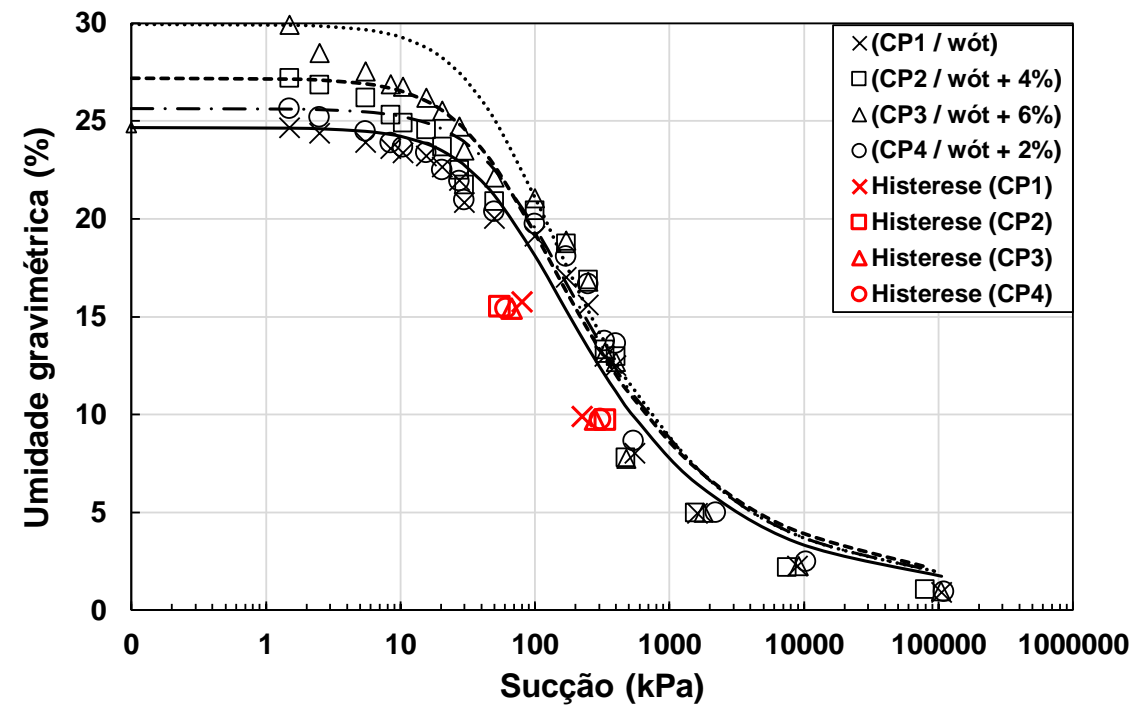


Figura 63 - Curva característica do solo obtida pelo método 1 (umidade volumétrica versus sucção)

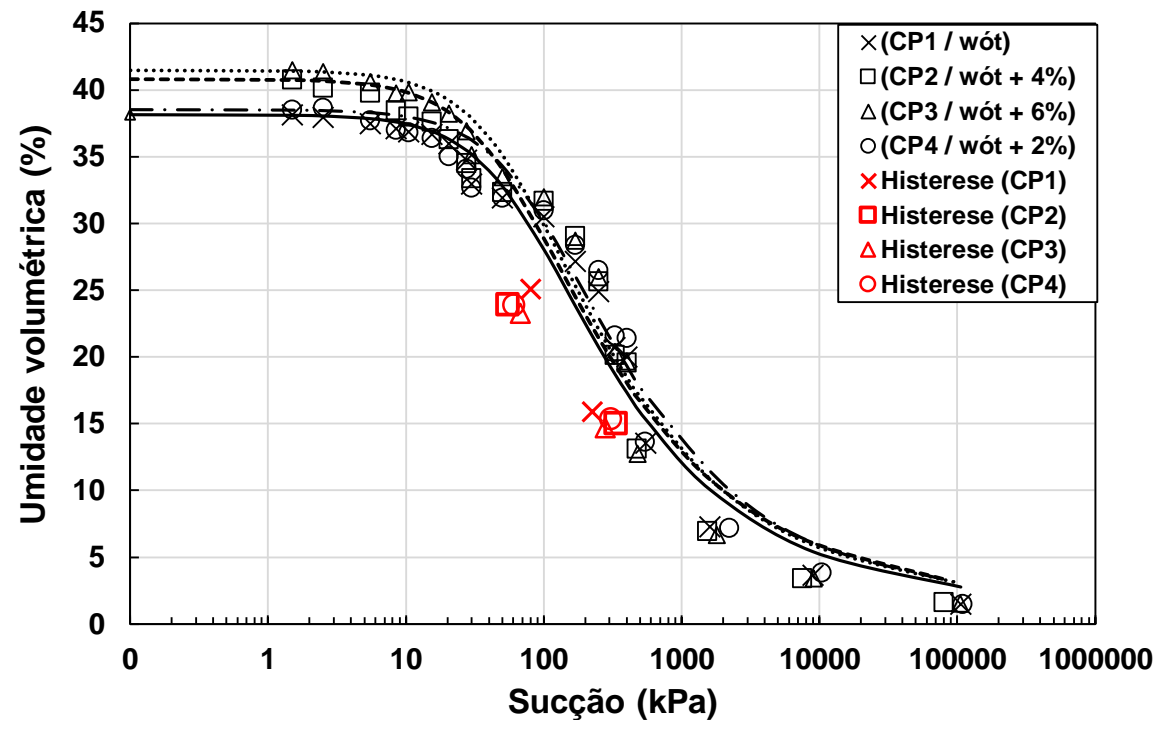

Figura 64 - Grau de saturação versus sucção obtida pelo método 1

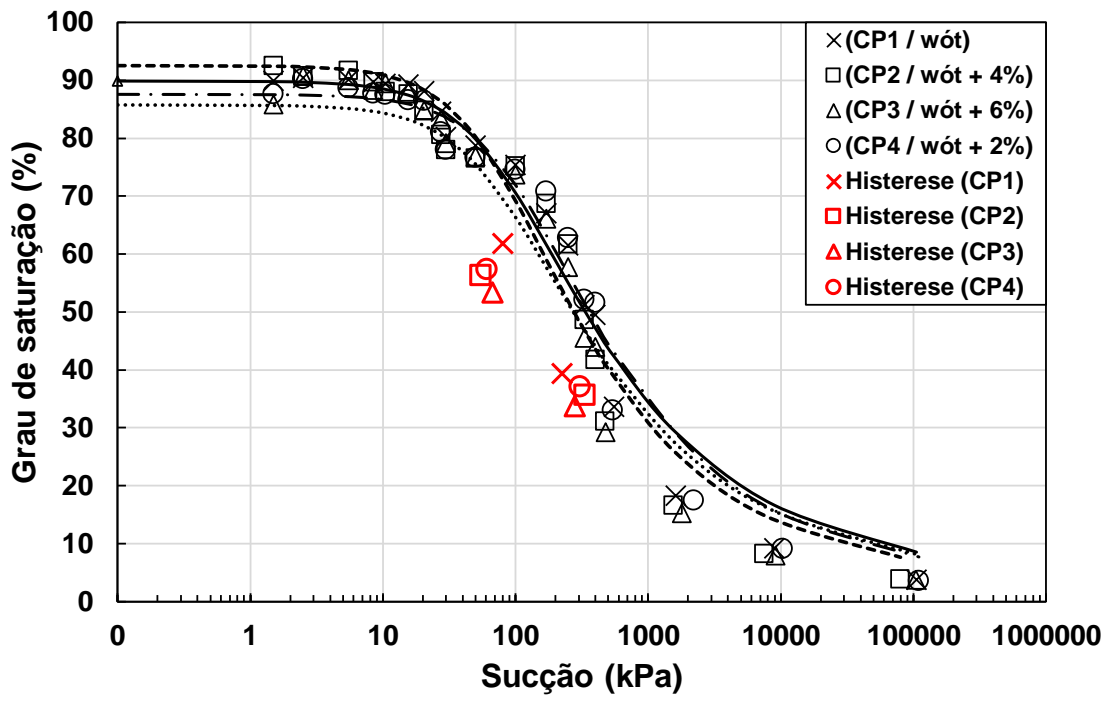

Figura 65 - Índice de vazios versus sucção obtida pelo método 1

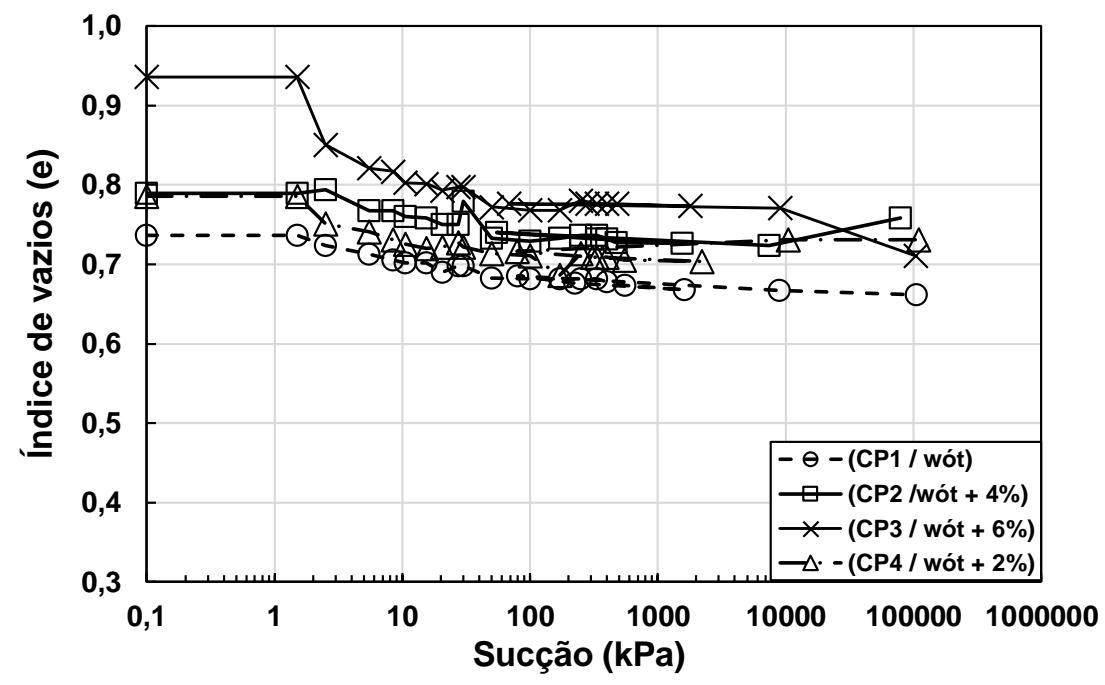


Como esperado, a partir dos pontos experimentais obtidos, verificou-se que a trajetória de secagem é diferente da trajetória de umedecimento, ou seja, o solo apresenta sucções diferentes para uma mesma umidade, obtidas por ambas as trajetórias. Além disso, a partir dos dados de umidade gravimétrica e volumétrica, verificou-se que os valores de sucção de entrada de ar e de umidade volumétrica saturada e residual, são condizentes com a literatura e com os valores obtidos pelo método 2 , respectivamente, para a mesma condição de compactação.

Desse modo, conclui-se que o método 2, considerado mais rápido, pode ser utilizado para a determinação da curva característica desse tipo de solo por secagem, em substituição ao método 1. A Tabela 9 apresenta as características de moldagem dos corpos de prova (CP) de dimensões $3,8 \times 2,0 \mathrm{~cm}$ e os valores dos parâmetros de ajuste obtidos pelo método 1 .

Tabela 9 - Características de moldagem dos corpos de prova (CP) e parâmetros de ajuste das curvas

\begin{tabular}{|c|c|c|c|c|c|c|c|c|c|}
\hline Subleito & $\begin{array}{l}\text { VEA } \\
(\mathrm{kPa})\end{array}$ & $\theta_{r}$ & $\theta_{s}$ & $\alpha$ & $n$ & Erro & $\begin{array}{c}\gamma_{\mathrm{s}} \\
\left(\mathrm{g} / \mathrm{cm}^{3}\right)\end{array}$ & $w(\%)$ & Modelo \\
\hline $\mathrm{CP} 1$ & 30 & 0,02760 & 0,38130 & 0,0149 & 1,457 & 3,42 & 1,6501 & 18,3 & \multirow{4}{*}{$\begin{array}{c}\text { Van } \\
\text { Genuchter } \\
(1980)\end{array}$} \\
\hline CP2 & 25 & 0,03360 & 0,40800 & 0,0182 & 1,457 & 6,34 & 1,5789 & 22,2 & \\
\hline CP3 & 30 & 0,03013 & 0,41494 & 0,0164 & 1,445 & 4,560 & 1,5949 & 24,6 & \\
\hline CP4 & 35 & 0,03014 & 0,38524 & 0,0120 & 1,445 & 4,21 & 1,6152 & 20,9 & \\
\hline
\end{tabular}

Dentre as curvas mencionadas, foi escolhida aquela obtida pelo método 2 para a caracterização hidráulica do material, pois além de ter apresentado o melhor ajuste (menor erro pelo método dos mínimos quadrados), ela foi determinada através da utilização do mesmo tipo de sensor instalado em campo, o que é considerado um aspecto importante no processo de calibração.

Ressalta-se que, a partir da curva característica selecionada, variou-se os seus parâmetros de ajuste, com o intuito de simular um solo mais arenoso $(\alpha=0,0667$ e $n$ (3) e outro mais argiloso ( $\alpha=0,005$ e $n=1,4$ ), obtendo-se duas novas curvas características, que serão utilizadas no item 4.2 para fins de comparação (Figura 66). 
Figura 66 - Curvas características: solo de campo e outras duas possíveis variações

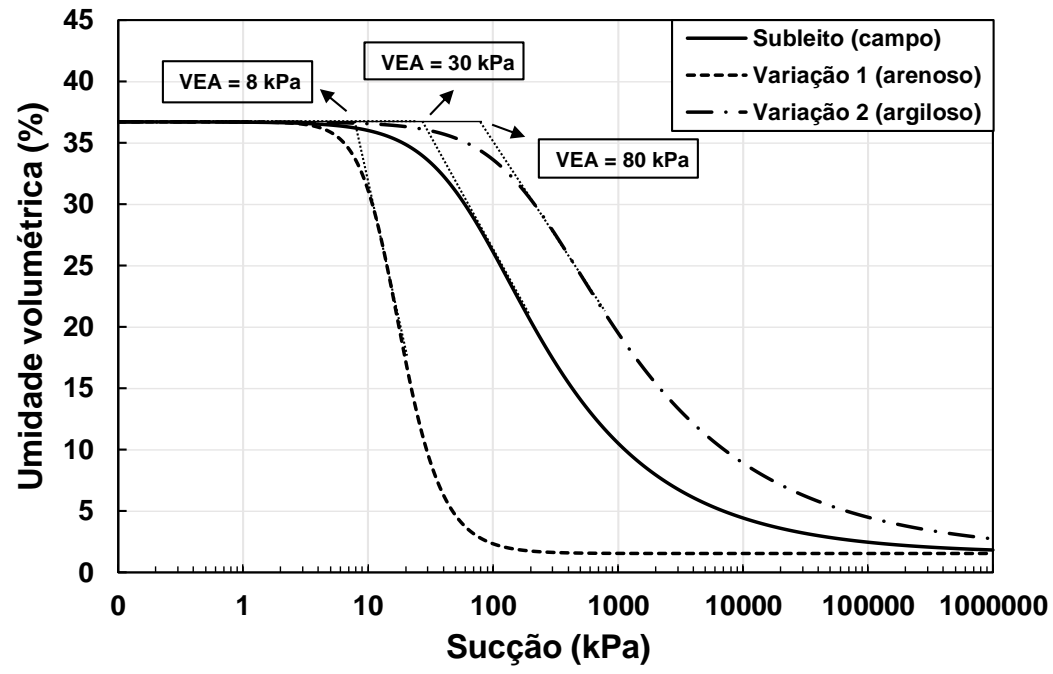

Conforme foi mencionado, o subleito foi considerado anisotrópico neste trabalho, em termos de permeabilidade devido a presença de partículas que podem ser posicionadas em várias direções durante a compactação. A Tabela 10 apresenta os valores de permeabilidade obtidas nas direções x e y, no ensaio Tri-flex 2.

Tabela 10 - Permeabilidade saturada do subleito nas direções $\mathrm{x}$ e y

\begin{tabular}{cccc} 
Materials & $\mathbf{k}_{\text {satx }}(\mathbf{m} / \mathbf{s})$ & $\mathbf{k}_{\text {saty }}(\mathbf{m} / \mathbf{s})$ & $\mathbf{k y} / \mathbf{k x}$ \\
\hline Subleito & $1 \times 10-7$ & $7 \times 10-8$ & 0,7
\end{tabular}

A curva de condutividade hidráulica do solo foi obtida utilizando-se a equação proposta por Van Genuchten (1980), aplicando-se os dados da condutividade hidráulica saturada $\left(\mathrm{k}_{\mathrm{sat}}\right)$ e da curva característica determinada pelo método 2.

Verificou-se que para um valor de sucção residual de aproximadamente $100.000 \mathrm{kPa}$, o solo alcança valores extremamente baixos de condutividade hidráulica não saturada. Ou seja, se o solo estiver submetido à climas áridos, no qual a taxa de evaporação excede a taxa de precipitação proporcionando um déficit hídrico, ele pode ser submetido a processos de secagem intensos, se tornando praticamente impermeável (Figura 67). 
Figura 67 - Curva de condutividade hidráulica do solo de subleito

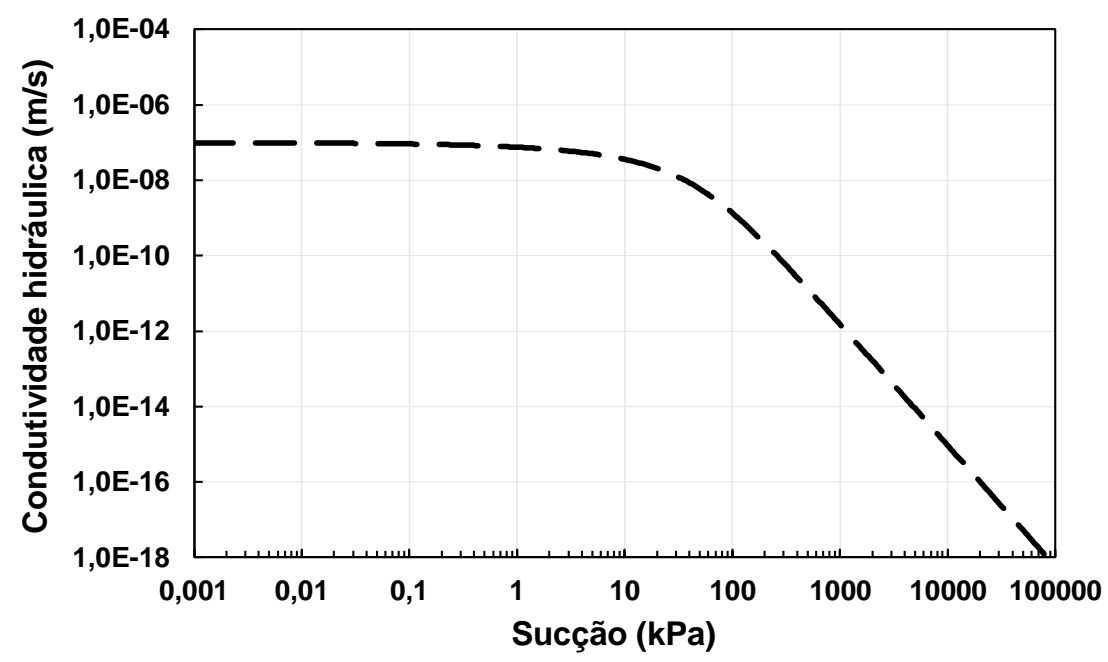

\section{Sublastro}

A curva característica do sublastro granular ou BGS de campo foi determinada a partir da equação proposta por Aubertin et al. (2003). Observou-se que seu valor de entrada de ar foi de aproximadamente 1,5 kPa, típico de materiais arenosos. Além disso, esse valor foi compatível com os valores de entrada de ar encontrados por Yaghoubi et al. (2016), o qual encontrou valores correspondentes à, aproximadamente, 0,5 kPa para materiais britados bem graduados utilizados em pavimentos na Austrália.

Este valor, encontrado também através da equação de Aubertin et al. (2003), foi sensivelmente inferior ao deste trabalho, devido a sua densidade inferior $\left(\gamma_{s}=1,999\right.$ $\mathrm{g} / \mathrm{cm}^{3}$ ) e sua maior uniformidade. Materiais menos densos e mais uniformes possuem maiores porosidades e, consequentemente, menor capacidade de retenção de água e menor valor de sucção da entrada de ar (VEA). A Figura 68 apresenta a curva característica estimada para o sublastro granular. 
Figura 68 - Curva característica do sublastro granular

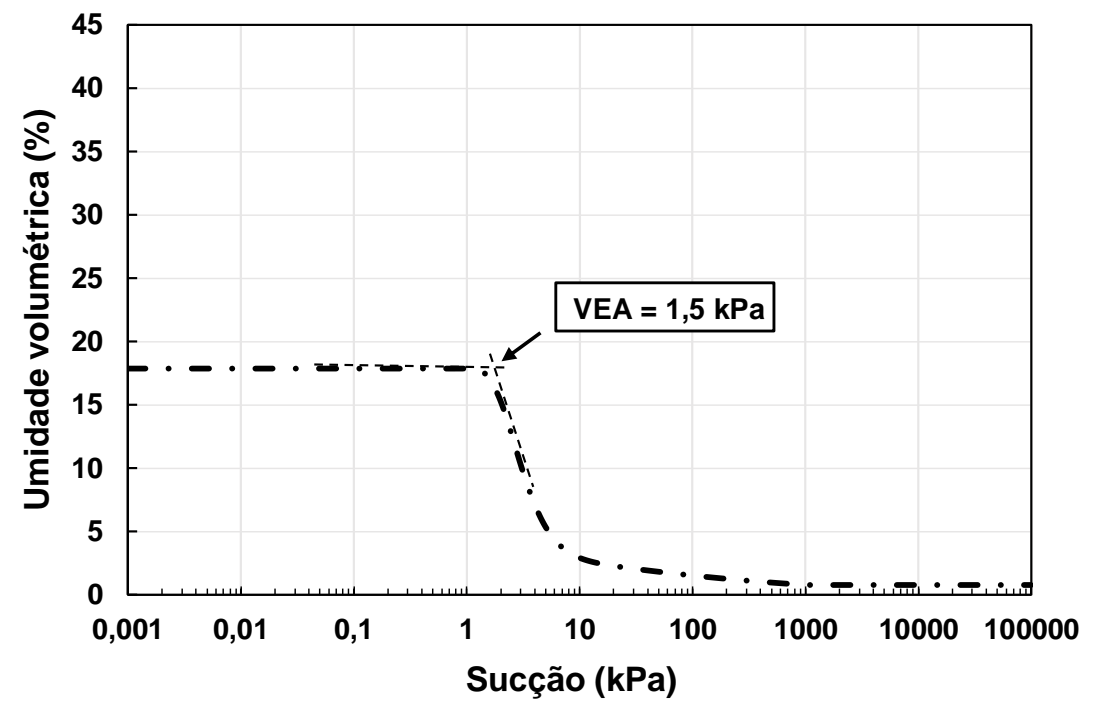

Observou-se que seu valor de entrada de ar foi de aproximadamente 1,5 $\mathrm{kPa}$, típico de materiais arenosos. Além disso, esse valor foi compatível com os valores de entrada de ar encontrados por Yaghoubi et al. (2016), o qual encontrou valores correspondentes à, aproximadamente, $0,5 \mathrm{kPa}$ para materiais britados bem graduados utilizados em pavimentos na Austrália.

Este valor, encontrado também através da equação de Aubertin et al. (2003) para este trabalho, foi sensivelmente inferior ao deste trabalho, devido a sua densidade inferior $\left(\gamma_{s}=1,999 \mathrm{~g} / \mathrm{cm}^{3}\right)$ e sua maior uniformidade. Materiais menos densos e mais uniformes possuem maiores porosidades e, consequentemente, menor capacidade de retenção de água e menor valor de sucção da entrada de ar.

Em termos de permeabilidade, diferentemente do solo de subleito, o sublastro foi considerado isotrópico em termos por ser considerado fragmentos de rocha não coesivo ou um material granular. Tennakoon et al. (2012) explicam que materiais granulares possuem a diferença da condutividade hidráulica vertical e horizontal menor que materiais muito finos como siltes e argilas. A estrutura porosa de materiais granulares com partículas grossas na direção vertical e horizontal é aleatória. Para a análise da condutividade hidráulica do sublastro, foram obtidos diferentes valores de permeabilidade para o mesmo, como apresentado na Tabela 11. 
Tabela 11 - Permeabilidade do sublastro (BGS)

\begin{tabular}{|c|c|c|c|}
\hline & \multicolumn{2}{|c|}{ ksat (m/s) } & \multirow{2}{*}{ Autor } \\
\hline Material & kx & ky & \\
\hline \multirow{4}{*}{$\begin{array}{l}\text { Sublastro } \\
\text { (BGS) }\end{array}$} & $6,33 \times 10^{-7}$ & $6,33 \times 10^{-7}$ & - \\
\hline & $3,66 \times 10^{-6}$ & $3,66 \times 10^{-6}$ & $\begin{array}{l}\text { Suzuki et al. } \\
(2013) \text { - B e C }\end{array}$ \\
\hline & $3,66 \times 10^{-8}$ & $3,66 \times 10^{-8}$ & \multirow{2}{*}{$\begin{array}{l}\text { Variações } \\
\text { possiveis }\end{array}$} \\
\hline & $3,66 \times 10^{-4}$ & $3,66 \times 10^{-4}$ & \\
\hline
\end{tabular}

A partir da curva característica determinada pela equação proposta por Aubertin et al. (2003) e dos valores de permeabilidade para este material, foi possível se estimar a curva de condutividade hidráulica do sublastro, pelo modelo de Fredlund et al. (1994). Assim, obtiveram-se as seguintes curvas expostas pela Figura 69.

Figura 69 - Curva de condutividade hidráulica do sublastro granular

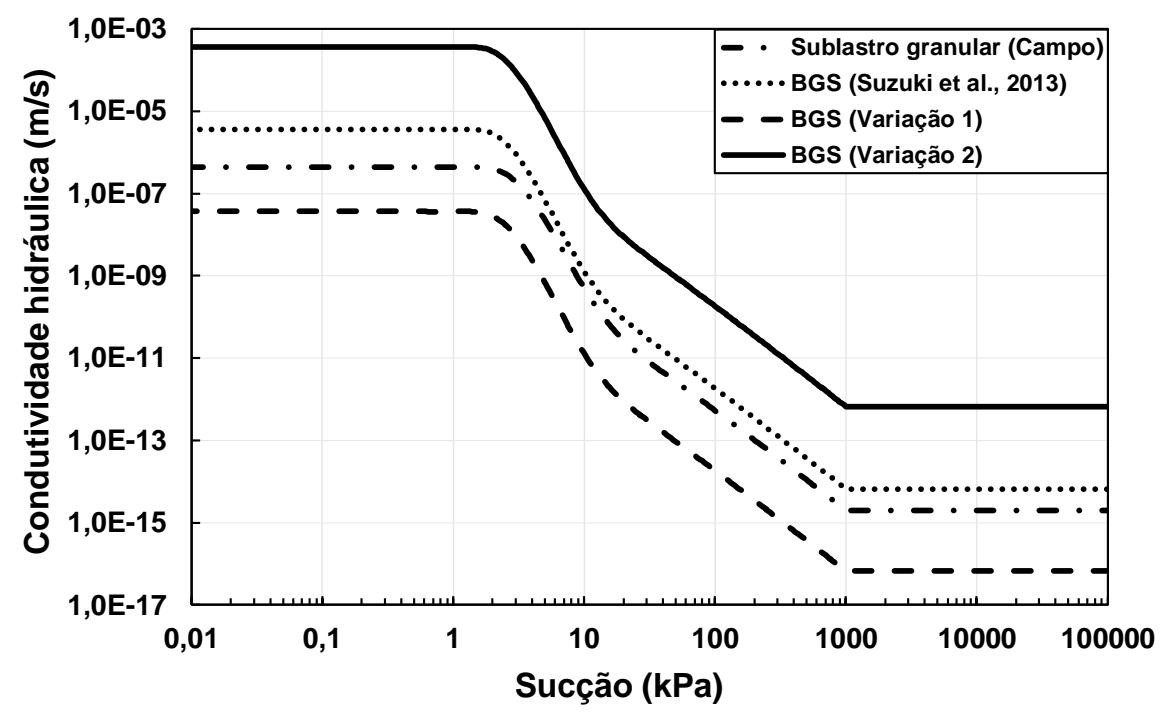

\section{$\underline{\text { Lastro }}$}

Realizou-se uma tentativa de obtenção da curva característica do lastro a partir do modelo proposto por Aubertin et al. (2003), a partir dos seus dados granulométricos e umidade volumétrica saturada (Figura 70 ). 
Figura 70 - Curva característica do lastro

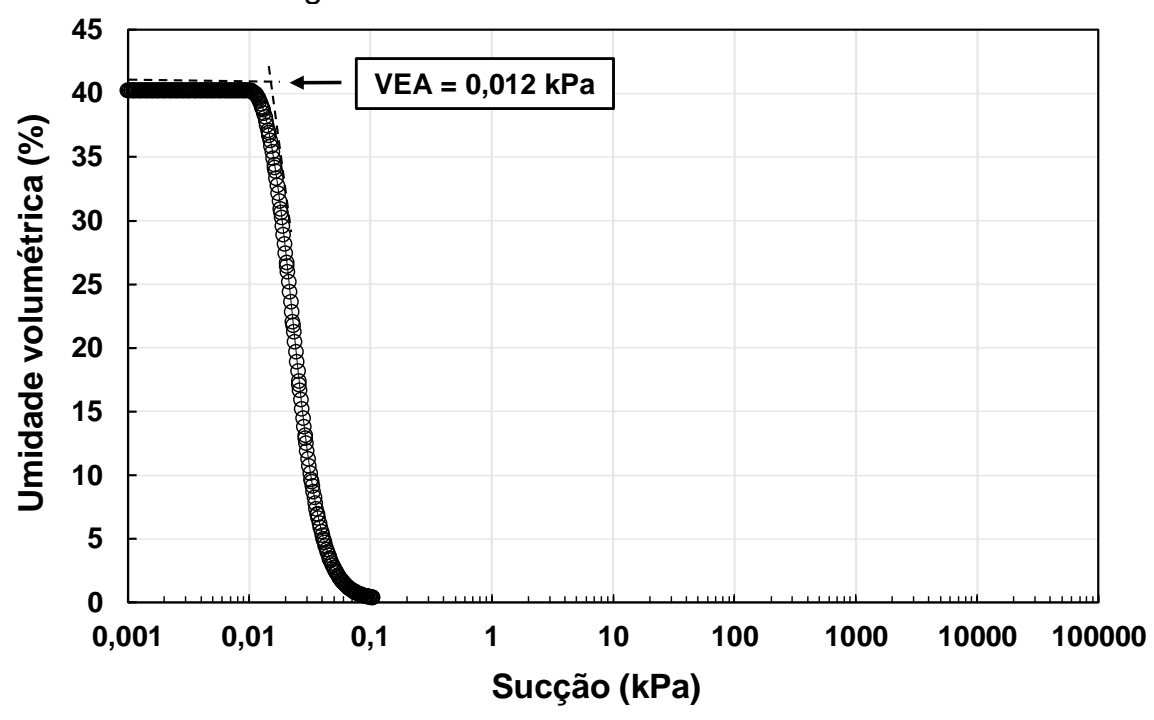

O baixíssimo e inviável valor de entrada de ar correspondente à $0,012 \mathrm{kPa}$, mostra que o lastro em sua condição não contaminada para essa faixa granulométrica (AREMA 3), não contribui para a dissipação de cargas de pressão por ser muito poroso, logo não possui curva característica. Tennakoon et al. (2012) relatam a existência de diversas equações analíticas para a determinação da condutividade hidráulica de solos granulares, as quais são bem aplicáveis na maioria das vezes para areias e siltes.

Enquanto isso, a mudança na condutividade hidráulica de agregados com elevada porosidade como o lastro é usualmente insensível, a menos que uma elevada quantidade de finos venha a preencher os vazios do mesmo, influenciando também na sua capacidade de retenção de água. Apesar disso, foram realizadas análises numéricas para comparar os dois casos, com e sem lastro, que será mostrado no início do item 4.2.

O material de lastro foi considerado isotrópico em termos de permeabilidade $\left(\mathrm{k}_{\mathrm{v}}=\mathrm{k}_{\mathrm{h}}\right)$ e foram obtidos através da equação de Moulton (1980), assim como o sublastro, obtendo-se o valor de $\mathrm{ksat}_{\mathrm{t}}=0,99 \mathrm{~m} / \mathrm{s}$, considerado plausível (Tabela 12).

Tabela 12 - Permeabilidade do lastro

\begin{tabular}{ccc} 
& \multicolumn{2}{c}{ ksat $(\mathbf{m} / \mathbf{s})$} \\
\hline Material & kx & ky \\
\hline Lastro & 0,99 & 0,99 \\
\hline
\end{tabular}


A fim de se verificar se a equação de Moulton (1980) é aceitável para a determinação da permeabilidade do lastro, foram consultados alguns trabalhos na literatura. Wnek et al. (2012), após analisar 13 diferentes materiais de lastro do oeste do rio Mississipi, EUA (pedreiras próximas ao UP railroad system) como mostra a Tabela 13, verificouse que o maior valor encontrado para o índice de vazios foi de 0,82 para lastro considerados de baixa densidade, e o menor valor de 0,48 .

Tabela 13 - Agregados de lastro de acordo com dados de laboratório e local de extração nos EUA

\begin{tabular}{|c|c|c|c|c|c|}
\hline Grupo & $\begin{array}{l}\text { Tipo de } \\
\text { lastro }\end{array}$ & Pedreira (local) & $\begin{array}{l}\text { Densidade } \\
\quad \text { (pcf) }\end{array}$ & $\begin{array}{l}\text { Densidade dos } \\
\text { grãos }\left(G_{s}\right)\end{array}$ & $\begin{array}{l}\text { Índice de } \\
\text { vazios (e) }\end{array}$ \\
\hline \multirow{5}{*}{$\begin{array}{l}\text { Densidade elevada (> } \\
\qquad 99 \text { pcf) }\end{array}$} & Lastro 1 & Granite Canyon, WY & 99,43 & 2,51 & 0,57 \\
\hline & Lastro 2 & Iron Mountain, MO & 99,94 & 2,41 & 0,50 \\
\hline & Lastro 3 & Uvalde, TX & 115,03 & 2,82 & 0,53 \\
\hline & Lastro 4 & Malvern, AR & 99,43 & 2,36 & 0,48 \\
\hline & Lastro 5 & Knippa, TX & 111,43 & 2,74 & 0,53 \\
\hline \multirow{3}{*}{$\begin{array}{l}\text { Densidade média (95- } \\
\qquad 99 \text { pcf) }\end{array}$} & Lastro 6 & Dell Rapids, SD & 96,00 & 2,33 & 0,51 \\
\hline & Lastro 7 & Milford, UT & 96,00 & 2,46 & 0,50 \\
\hline & Lastro 8 & Oroville, CA & 98,06 & 2,60 & 0,65 \\
\hline \multirow{5}{*}{$\begin{array}{c}\text { Densidade baixa (<95 } \\
\text { pcf) }\end{array}$} & Lastro 9 & Piedmont, MO & 94,29 & 2,32 & 0,53 \\
\hline & Lastro 10 & Little Rock, AR & 89,14 & 2,29 & 0,60 \\
\hline & Lastro 11 & North Powder, OR & 94,29 & 2,51 & 0,66 \\
\hline & Lastro 12 & Mill Creek, OK & 94,29 & 2,32 & 0,54 \\
\hline & Lastro 13 & Sierra Blanca, TX & 89,14 & 2,60 & 0,82 \\
\hline
\end{tabular}

Fonte: adaptado de Wnek et al. (2012).

Diante desses valores, verificam-se valores de 0,32 a 0,45 de porosidade $(\eta)$ para 0 lastro bem e mal estabilizados, respectivamente. Isso é equivalente a valores de permeabilidade de 0,1 a $0,97 \mathrm{~m} / \mathrm{s}$. Tennakoon et al. (2012) realizaram ensaios de permeabilidade em grande escala com o lastro para a determinação da sua curva de condutividade hidráulica, obtendo-se assim um valor de $\mathrm{k}_{\mathrm{sat}}=0,3 \mathrm{~m} / \mathrm{s}$, similar àqueles apresentados anteriormente. Ou seja, conclui-se que a equação de Moulton foi eficiente na determinação da permeabilidade do lastro para este trabalho.

A partir do valor da condutividade saturada do lastro ( $\left.k_{\text {sat }}=0,9 \mathrm{~m} / \mathrm{s}\right)$ e da sua curva característica, determinou-se a sua curva de condutividade hidráulica, considerandose a possibilidade de o mesmo estar limpo, possuindo uma permeabilidade constante, até alcançar aquele valor obtido por Tennakoon et al. (2012), para esta mesma condição (Figura 71). 
Figura 71 - Curva de condutividade hidráulica do lastro

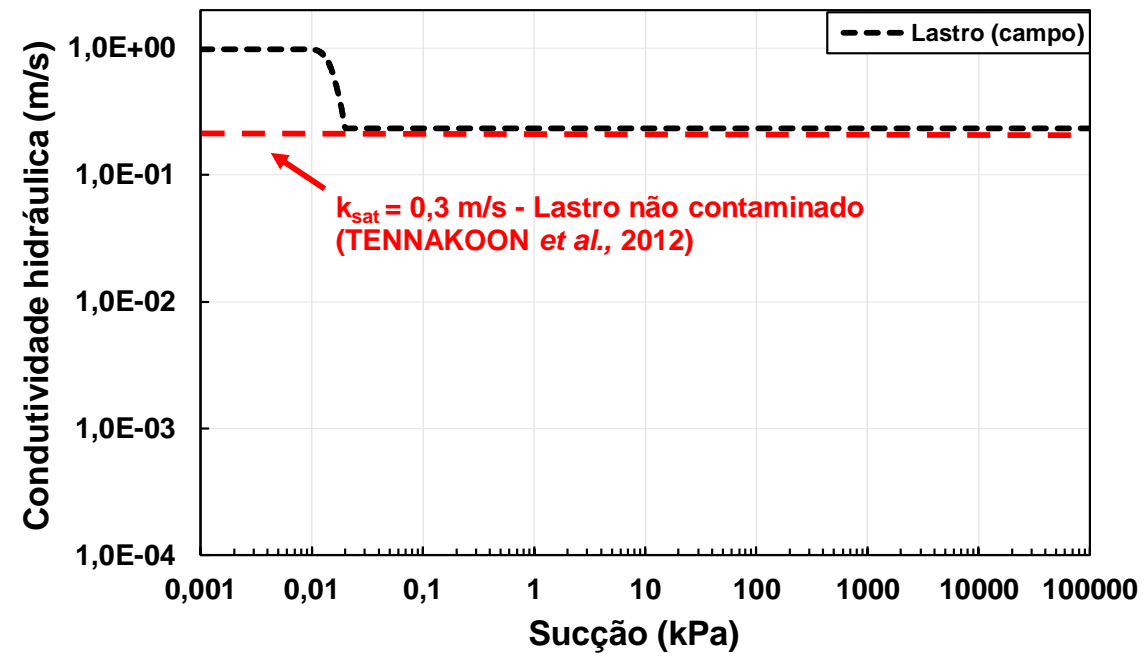

\section{2 - Modelagem numérica}

A partir da caracterização física e hidráulica dos materiais geotécnicos da via permanente em estudo, foi possível desenvolver um modelo numérico de infiltração saturada/não saturada de seu perfil estrutural. Os dados utilizados no modelo e nas análses (inputs) para cada material estão apresentados e resumidos nas Tabelas 14 e 15 .

Tabela 14 - Dados da curva característica dos materiais

\begin{tabular}{|c|c|c|c|c|c|c|c|c|c|}
\hline Material & Análise & $\begin{array}{l}\text { VEA } \\
(\mathrm{kPa})\end{array}$ & $\theta_{\mathrm{r}}$ & $\theta_{s}$ & $\alpha$ & $\mathbf{n}$ & $D_{10}$ & $D_{60}$ & Modelo \\
\hline \multirow{3}{*}{ Subleito } & \multirow{3}{*}{$\begin{array}{c}\text { Não } \\
\text { saturada }\end{array}$} & 30 & \multirow{3}{*}{0,05720} & \multirow{3}{*}{0,36750} & 0,0157 & 1,493 & \multirow{3}{*}{-} & \multirow{3}{*}{ - } & \multirow{3}{*}{$\begin{array}{c}\text { Van Genuchter } \\
(1980)\end{array}$} \\
\hline & & 8 & & & 0,0067 & 3,000 & & & \\
\hline & & 80 & & & 0,0050 & 1,400 & & & \\
\hline Sublastro & $\begin{array}{c}\text { Não } \\
\text { saturada }\end{array}$ & 1,5 & 0,00360 & 0,18000 & - & - & 0,2 & 1,7 & $\begin{array}{c}\text { Aubertin et al. } \\
\text { (2003) }\end{array}$ \\
\hline Lastro & $\begin{array}{c}\text { Não } \\
\text { saturada }\end{array}$ & 0,012 & - & 0,40000 & - & - & - & - & $\begin{array}{c}\text { Aubertin et al. } \\
\text { (2003) }\end{array}$ \\
\hline
\end{tabular}

Tabela 15 - Dados de permeabilidade dos materiais

\begin{tabular}{|c|c|c|c|c|}
\hline \multirow[b]{2}{*}{ Material } & \multicolumn{2}{|c|}{ ksat (m/s) } & \multirow{2}{*}{ Autor } & \multirow{2}{*}{ Item } \\
\hline & kx & ky & & \\
\hline Subleito & $1 \times 10^{-7}$ & $7 \times 10^{-8}$ & - & Todos \\
\hline \multirow{3}{*}{ Sublastro (BGS) } & $3,66 \times 10^{-6}$ & $3,66 \times 10^{-6}$ & $\begin{array}{l}\text { Suzuki et al. } \\
\text { (2013) BGS B e C }\end{array}$ & $\begin{array}{c}4.2 .1 / 4.2 .2 / 4.2 .3 / 4.2 .4 / \\
4.2 .5 . b / 4.2 .6 / 4.2 .7\end{array}$ \\
\hline & $3,66 \times 10^{-8}$ & $3,66 \times 10^{-8}$ & \multirow{2}{*}{$\begin{array}{l}\text { Possíveis } \\
\text { variações }\end{array}$} & 4.2.5.a / 4.2.6 \\
\hline & $3,66 \times 10^{-4}$ & $3,66 \times 10^{-4}$ & & 4.2 .6 \\
\hline Lastro & 0,99 & 0,99 & - & Teste inicial \\
\hline
\end{tabular}


Primeiramente, foi necessário verificar se a camada de lastro sem contaminação influenciaria o comportamento hidráulico do subleito, visto que a sua consideração exige maior memória e tempo computacional. As Figuras 72 e 73 apresentam os gráficos da variação da sucção em função do tempo, considerando-se os dados climáticos de 2016, para a via ferroviária sem e com a camada de lastro.

Figura 72 - Variação da sucção versus tempo desconsiderando-se a camada de lastro

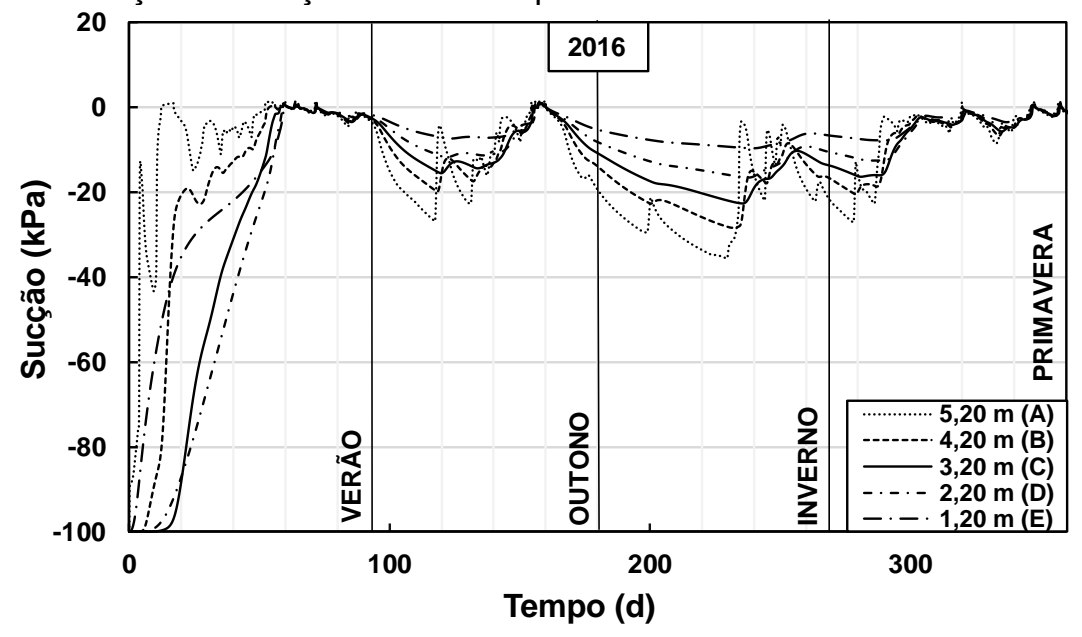

Figura 73 - Variação da sucção versus tempo considerando-se a camada de lastro

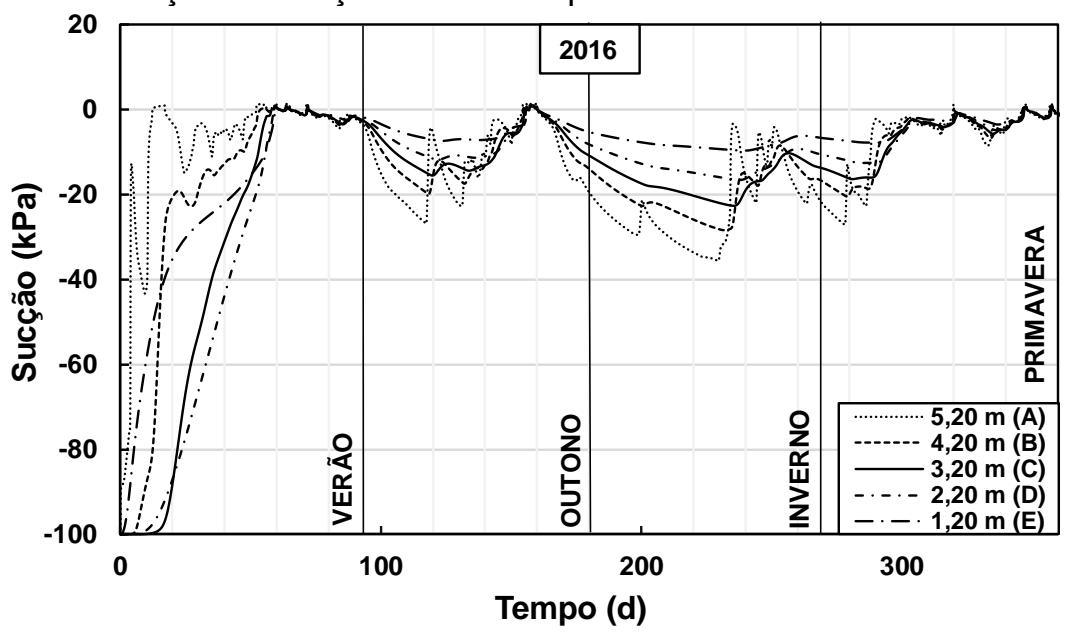

Conforme foi comentado no tópico 3.5, sabe-se que quanto maior o modelo numérico, maior será a análise e o tempo computacional para geração de dados e maior será a probabilidade de haver problemas de convergência. Como não houveram diferenças entre os dois cenários acima, decidiu-se desconsiderar a camada de lastro das análises seguintes, a fim de facilitar os cálculos numéricos. 


\subsection{1 - Balanço hídrico do perfil estrutural da via permanente}

As primeiras simulações e análises de infiltração transiente através do método dos MEF do perfil da via permanente, foram realizadas diariamente, em um intervalo de 715 dias, baseando-se nos dados climáticos de 2016-2017. As quatro estações dos dois anos foram verificadas. O tempo de análise do modelo (time step) foi de 30 minutos. Após a obtenção dos resultados, foi realizada a análise do balanço hídrico, considerando-se os dados obtidos da somatória da precipitação, evaporação real, escoamento e infiltração na superfície (sublastro e subleito) ao longo do ano. As Figuras 74, 75 e 76 apresentam gráficos do balanço hídrico obtido como resultado da modelagem numérica durante dois anos de eventos de precipitação e evaporação.

Figura 74 - Balanço hídrico versus tempo para os anos de 2016 e 2017

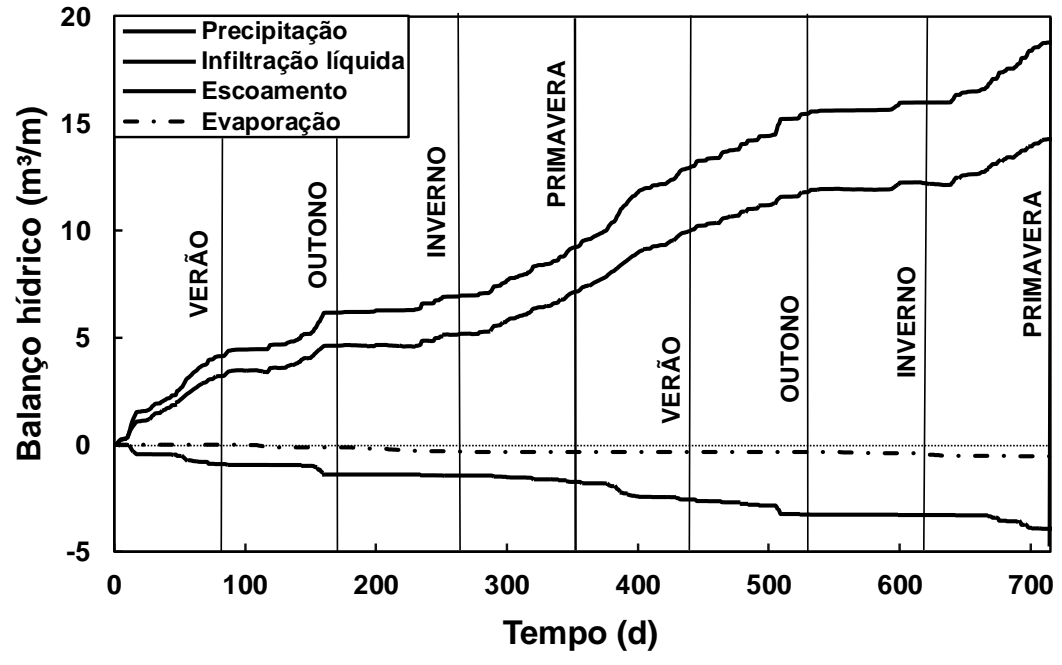

Figura 75 - Evaporação real e potencial

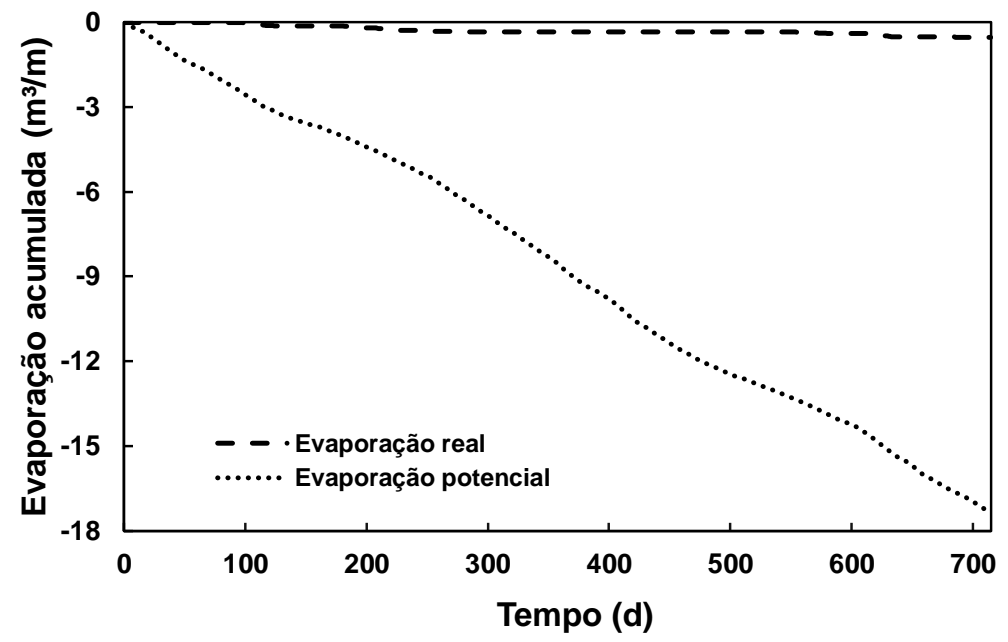


Figura 76 - Evaporação e infiltração efetivas

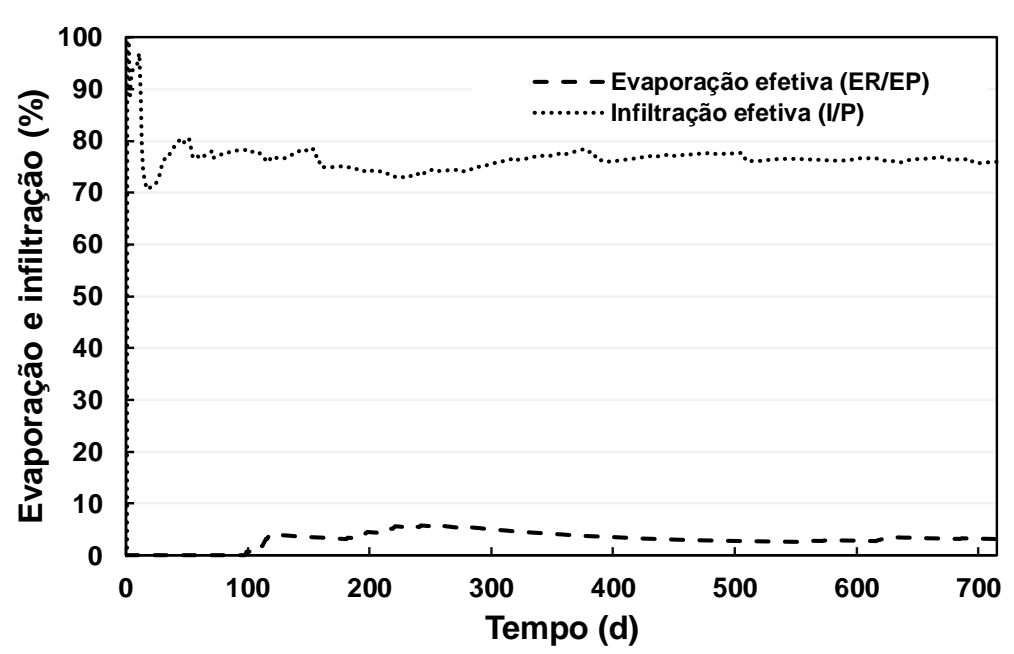

A partir da Figura 74, verificou-se que a infiltração líquida é elevada e resultado da subtração entre a precipitação acumulada, o escoamento e a evaporação real e que a influência do escoamento na infiltração é maior do que a evaporação. Isso pode ser observado também através da Figura 75, a qual evidencia uma diferença significativa entre a evaporação real e a evaporação potencial, correspondendo a $3 \%$ de evaporação efetiva. Apesar da sua baixa influência, verificou-se que a evaporação prevalece durante o inverno, em decorrência da não ocorrência da precipitação.

É importante observar também que o escoamento superficial prevalece somente durante a primavera e o verão, quando a precipitação ocorre em grande quantidade, gerando excedente hídrico. Pode ser observado, a partir da Figura 76, que após 2 anos, o valor de infiltração efetiva (infiltração líquida acumulada dividida pela precipitação acumulada), corresponde a $76 \%$. Isso demonstra que $76 \%$ da precipitação é convertida em infiltração, e os $24 \%$ restantes representam o escoamento superficial e a evaporação real.

A questão da infiltração efetiva foi estudada por diversos autores, dentre eles podem ser destacados Rossi e Donnini (2018), os quais relatam que a infiltração efetiva pode variar de 19 a 88\%, dependendo do tipo de solo. Percebe-se que a infiltração no solo ocorre em maior quantidade, durante a primavera e o verão, quando os eventos chuvosos são mais rotineiros, reduzindo durante o outono e cessando durante o inverno. 


\subsection{2 - Sucção/grau de saturação do subleito versus tempo}

As Figuras 77 e 78 apresentam os gráficos da variação da sucção e da umidade ao longo das quatro estações do ano para os anos de 2016 e 2017, respectivamente.

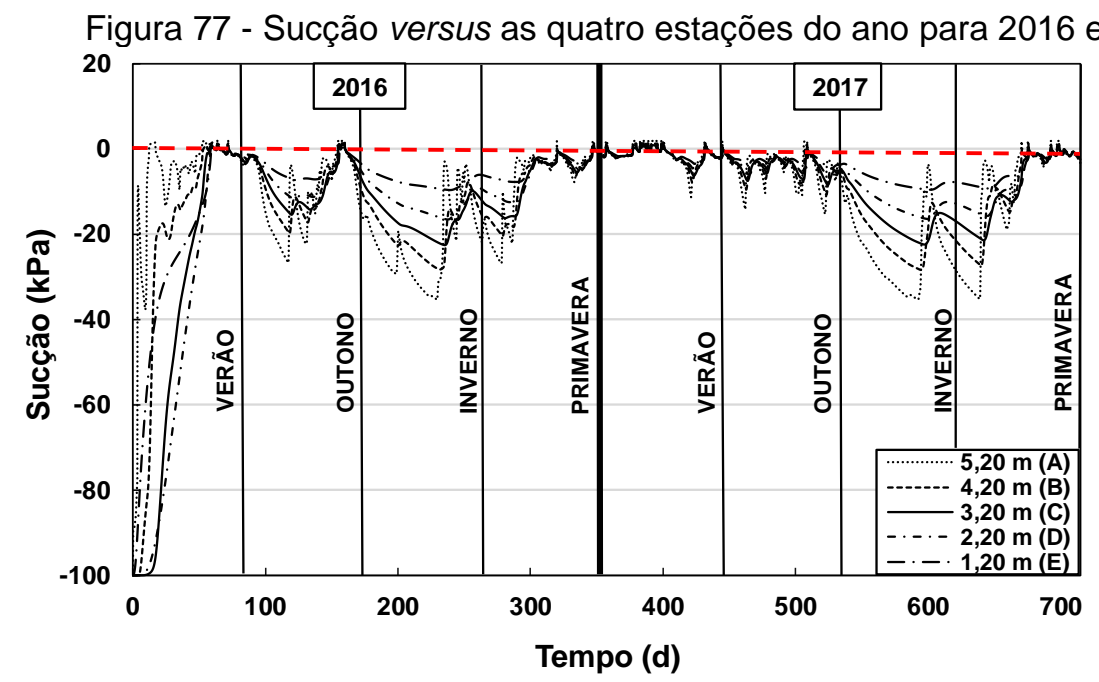

Figura 78 - Grau de saturação versus as quatro estações do ano para 2016 e 2017

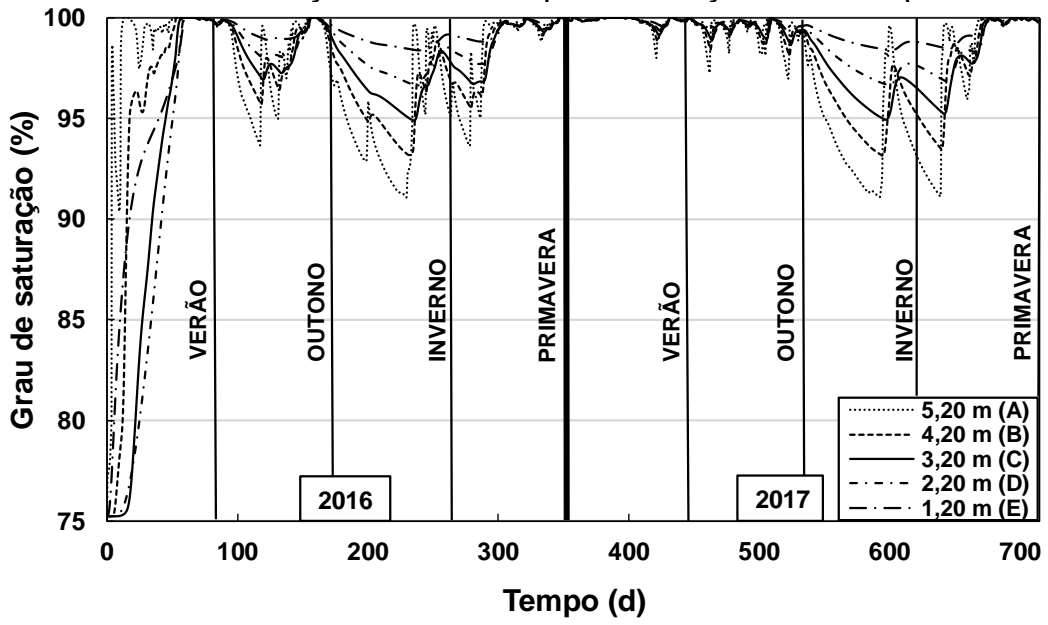

Verifica-se que, ao longo do tempo, o clima da região não permite que o solo retorne para a sua condição de saturação inicial na qual o mesmo foi compactado na umidade ótima (tempo 0) e, além disso, que a variação da sucção é muito baixa. Isso é importante ressaltar pois, todo o gasto energético utilizado para a compactação desse tipo de solo na umidade ótima, não impediu que seu comportamento hidráulico fosse impactado pelo clima. Em outras palavras, os resultaram mostraram que o clima e o tipo de solo são fatores fundamentais que influenciam a umidade de equilíbrio do solo 
de subleito a qual, já se sabe, exerce um importante papel no seu comportamento mecânico. No geral, o solo apresentou aumento nos valores de sucção após os períodos chuvosos serem interrompidos, que acontece no inverno (estação seca), confirmando o que foi mostrado na análise do balanço hídrico.

De acordo com as condições climáticas apresentadas e os dados de poropressão, o subleito demonstrou ter o mesmo comportamento hidráulico em ambos os anos. Baseando-se nisso, verificou-se que a umidade e o grau de saturação se elevam especialmente durante o verão (estação chuvosa), quando seus valores de sucção se mantêm próximo a $0 \mathrm{kPa}$ (condição saturada) nas proximidades da superfície do subleito, podendo contribuir para o aparecimento de deformações permanentes.

\subsection{3 - Estações do ano versus comportamento hidráulico do subleito}

\section{Verão}

O verão em áreas da costa brasileira é caracterizado por uma estação de elevada taxa de precipitação com eventos chuvosos duradouros e/ou intensos (INMET, 2018). Isto ocorre devido as elevadas temperaturas do ar que contribui para o aumento da taxa de evaporação dos oceanos. Considerando-se isto, ciclos de umedecimento e as condições de saturação do subleito foram analisados do dia 0 ao 59, e do dia 360 ao 450 , objetivando-se entender como eventos chuvosos influenciam nos valores de sucção do subleito (Figuras 79 e 80).

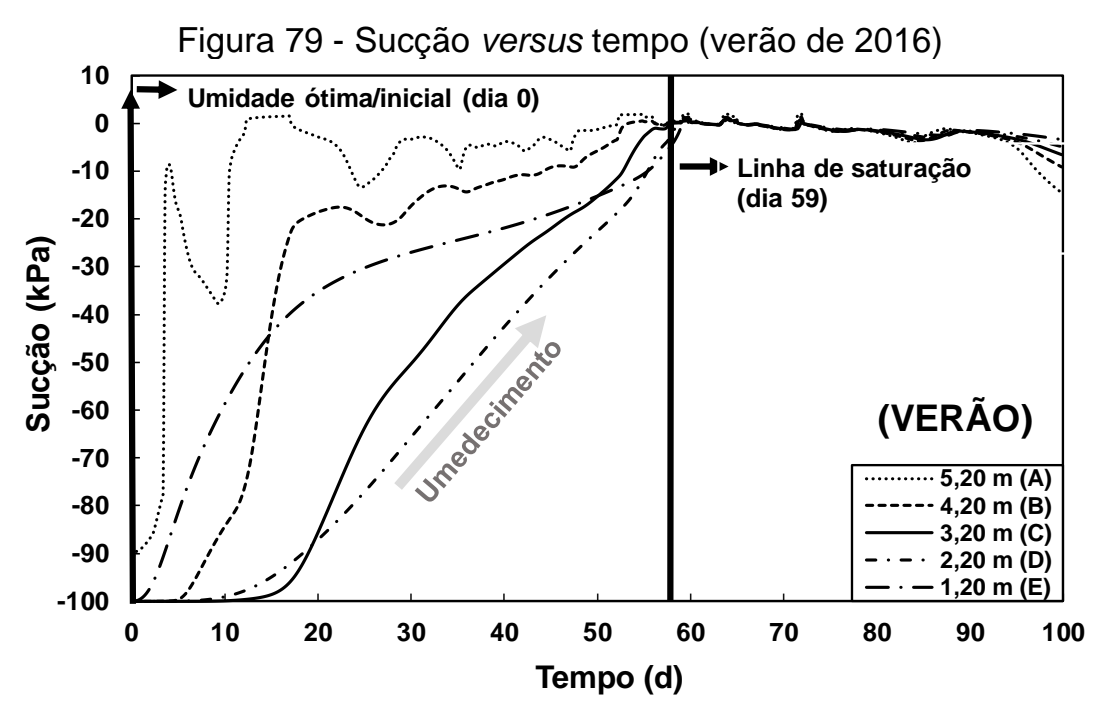




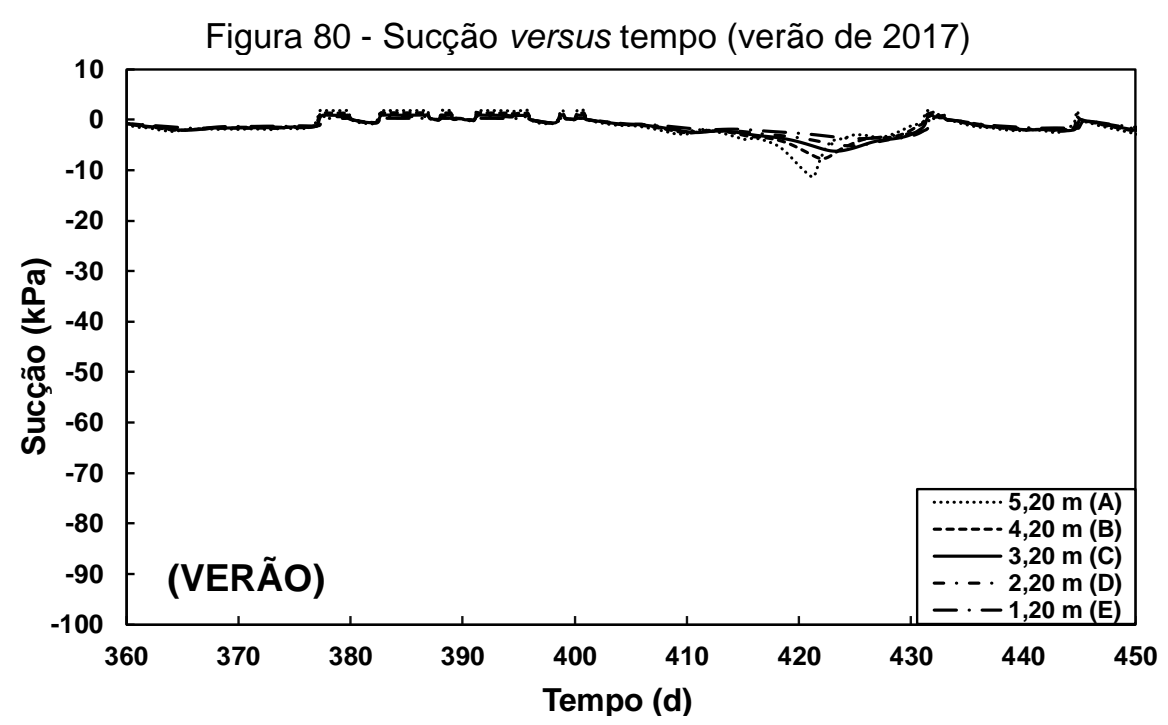

Observou-se que uma taxa de precipitação acumulada de $480 \mathrm{~mm}$ ocorrida do dia 0 ao dia 58 ocasionou a saturação do subleito compactado na umidade ótima no verão de 2016. Após esse período, uma taxa de precipitação acumulada de $140 \mathrm{~mm}$ induziu o solo a permanecer com elevado grau de saturação até o outono, totalizando 620 mm de chuva no verão.

Com relação verão de 2017, este foi caracterizado como um período muito úmido tanto quanto 2016, com uma taxa de precipitação acumulada de $610 \mathrm{~mm}$. A principal diferença entre o verão de 2016 e 2017 foi o tempo para que o solo alcançasse o equilíbrio com o clima.

No ano de 2016, o solo partiu da sua condição de contorno inicial (umidade ótima), sendo necessários 50 dias para que o mesmo atingisse a condição de equilíbrio, que para o clima local e este tipo de solo, é próxima à saturação ou baixos valores de sucção. Isso pode impactar de forma severa, o comportamento mecânico do subleito em termos de resistência e módulo de resiliência, como será abordado mais adiante neste trabalho (Tópico 4.4). As Figuras 81 e 82 apresentam os perfis de sucção vem função da profundidade para o verão de 2016 e 2017, respectivamente. 
Figura 81 - Sucção versus profundidade (verão de 2016)

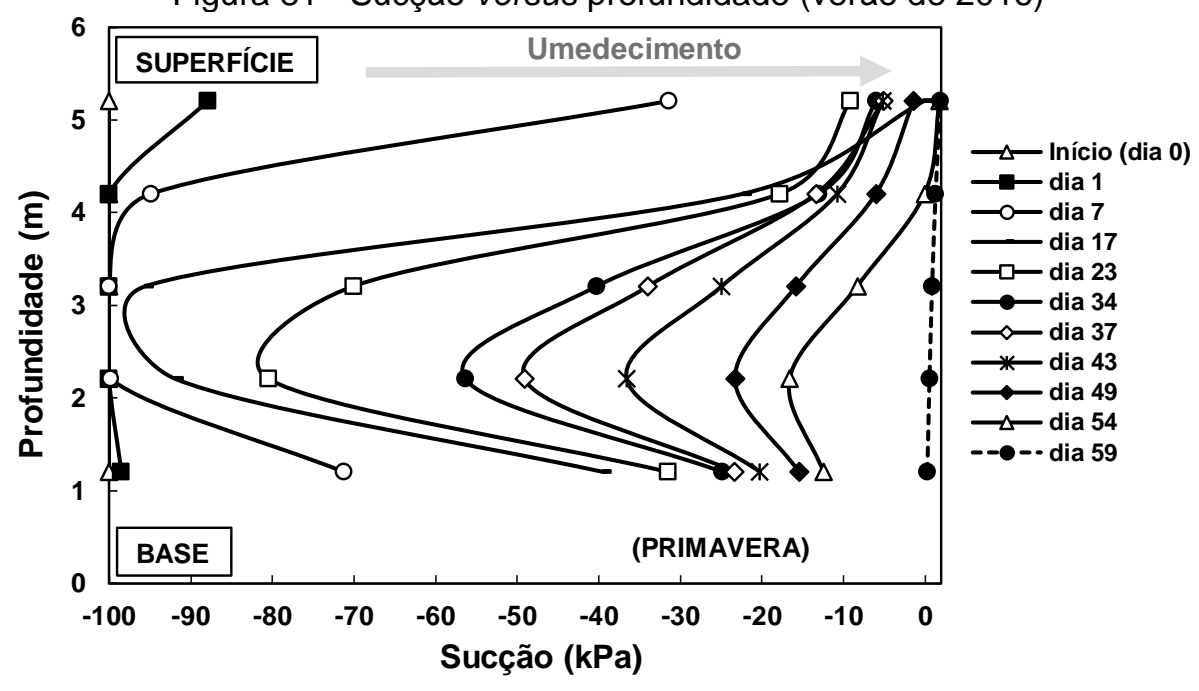

Figura 82 - Sucção versus profundidade (verão de 2017)

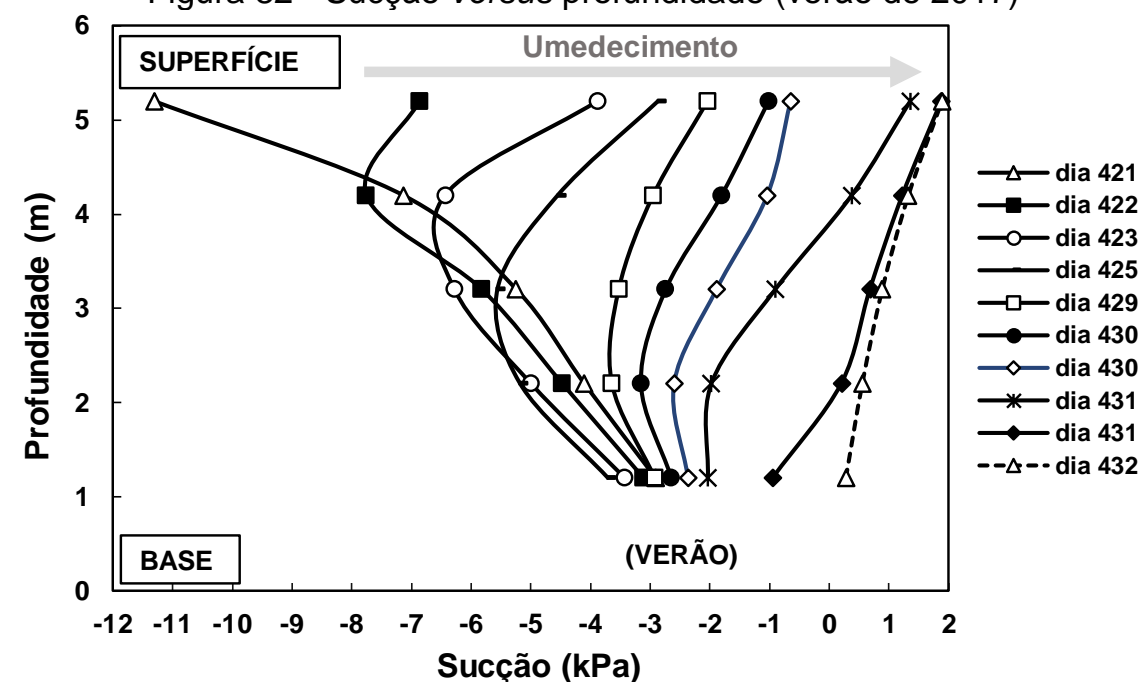

Verificou-se que, no ano de 2016, o solo começa o processo de umedecimento ou equilíbrio com clima na superfície do subleito, pela precipitação, e nas proximidades do lençol freático, pela capilaridade, do dia 1 ao dia 59. Logo em seguida, os pontos localizados entre o topo e base, inevitavelmente também começa a elevar sua umidade, em decorrência da quantidade de chuva deste período, que não permite o solo passar pelo processo de dessaturação.

Em ambos os anos, observam-se maiores variações de umidade e sucção no topo do subleito quando comparado com profundidades maiores, em decorrência da maior interação da superfície com o clima, ou seja, maior sensibilidade dos primeiros $2 \mathrm{~m}$ a variações das condições climáticas. Ressalta-se que a superfície do subleito se 
mantém com elevado grau de saturação durante todo verão, em decorrência da elevada taxa de precipitação. A fim de verificar a influência da via sobreposta ao solo de subleito durante o verão, foram analisadas as variações dos valores de sucção em função da distância transversal (Figuras 83 e 84).

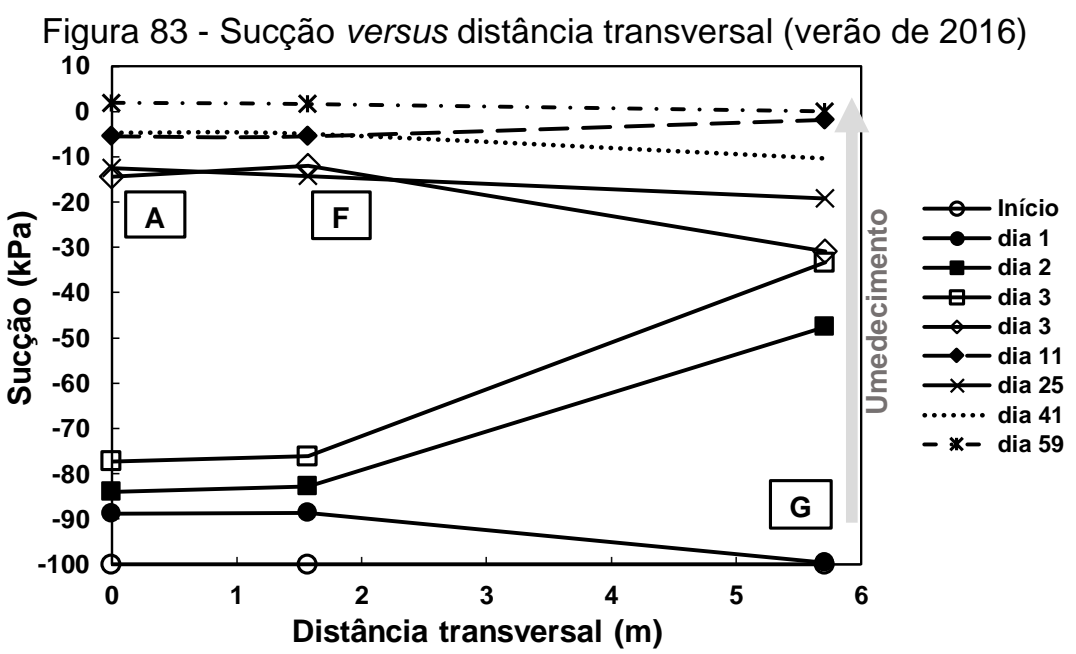

Figura 84 - Sucção versus distância transversal (2017)

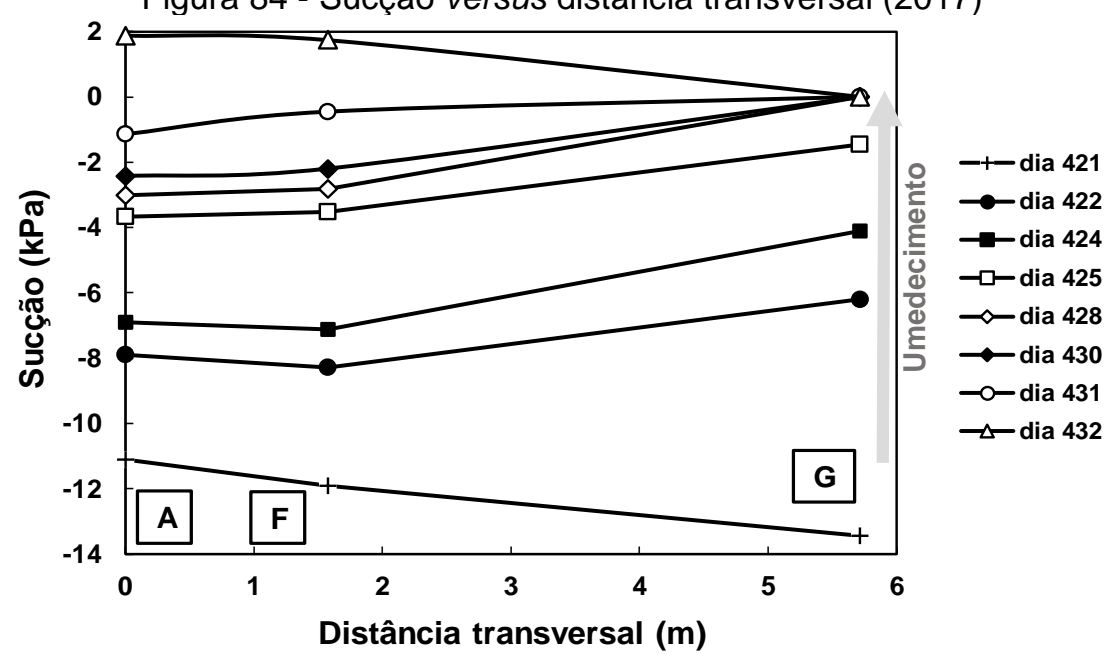

A partir dos perfis de sucção apresentados pelas Figuras 83 e 84, confirmou-se que foram necessários 58 dias para que o solo atingisse a saturação durante o verão inteiro após sua condição inicial de compactação, mostrando que este solo não é apropriado para este local em decorrência de períodos extremos de chuva. Além disso, os resultados apresentaram que a camada de sublastro granular é indispensável para estas condições climáticas particulares. Em outras palavras, verifica-se que o sublastro cumpre o seu papel drenante, mesmo durante pouco tempo 
(3 dias), tendendo a transportar a água da chuva que incide sobre a via para os pontos laterais mais distantes quando o mesmo está em condições não saturadas (menores condutividades hidráulicas), contribuindo para manter valores elevados de sucção até que o mesmo inicie o processo de umedecimento e possibilite a passagem de água para o subleito. Apesar disso, verificou-se que as características físicas (índice de vazios e porosidade) do sublastro aplicado, não foram suficientes para conter a água e proteger o subleito por muito tempo, como pôde ser observado após o subleito atingir valores de sucção de $0 \mathrm{kPa}$, correspondendo a condição saturada do material.

Como a capacidade de retenção de água do sublastro está relacionada à sua densidade (índice de vazios e porosidade), verificou-se que o estado de compactação na energia normal não foi satisfatório para que o sublastro pudesse alcançar valores maiores de sucções e consequentemente valores menores de condutividade hidráulica. Logo, recomenda-se a utilização de um material poroso com maior valor de entrada de ar que possa consequentemente atingir valores baixos de condutividade hidráulica. As Figuras 85 e 86 mostram um exemplo do sublastro realizando sua função drenante em condição não saturada e perdendo esta função logo após sua completa saturação, respectivamente.

Figura 85 - Exemplo de drenagem em sublastro granular em condição não saturada

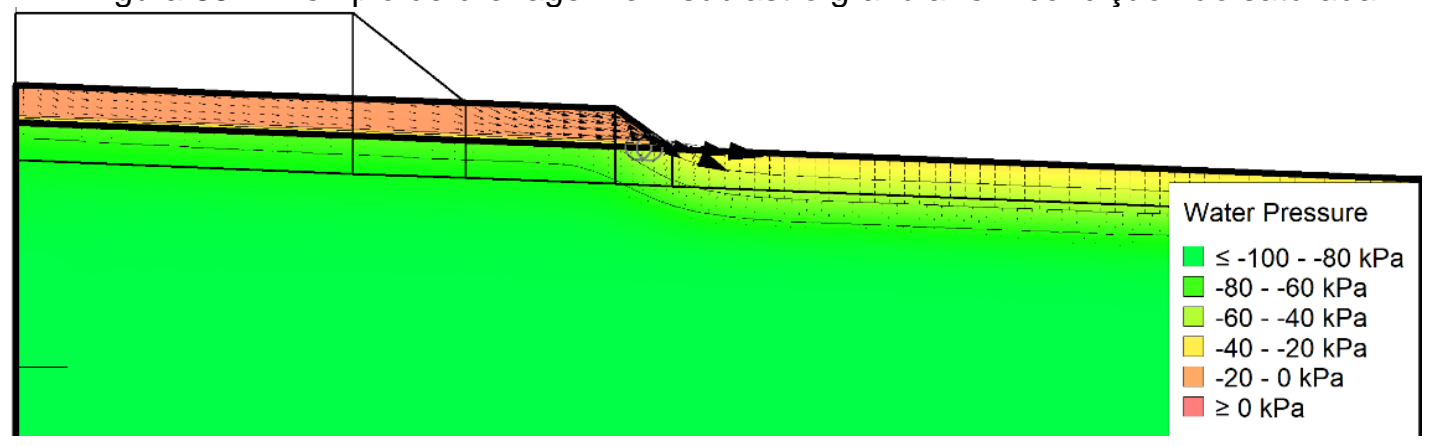

Figura 86 - Exemplo de saturação do sublastro granular

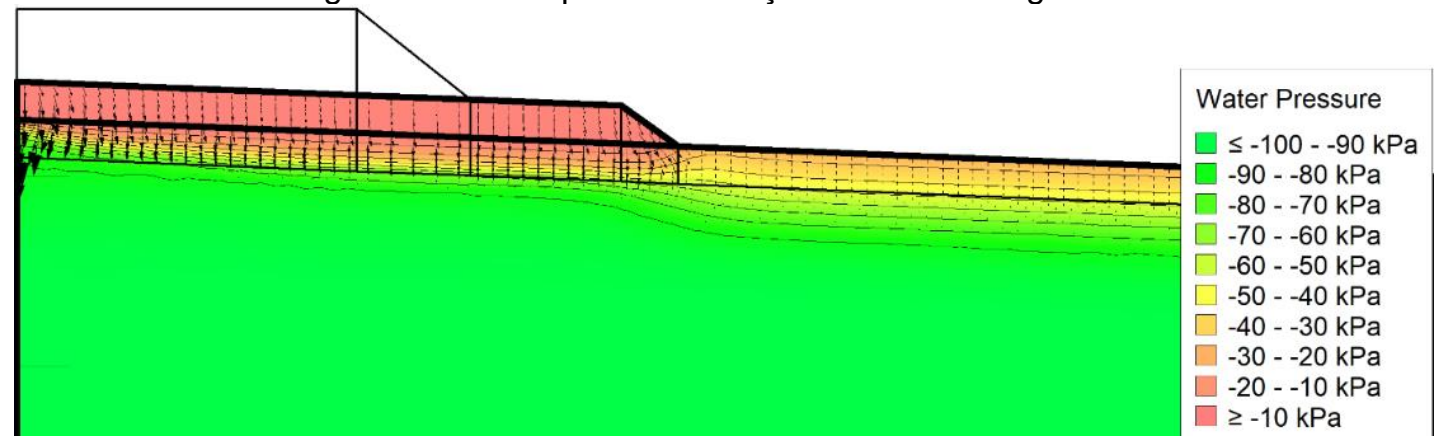




\section{$\underline{\text { Outono }}$}

As Figuras 87 e 88 apresentam a condição de saturação ou comportamento hidráulico do subleito durante o outono de 2016 e 2017, respectivamente.

Figura 87 - Sucção versus tempo (outono de 2016)

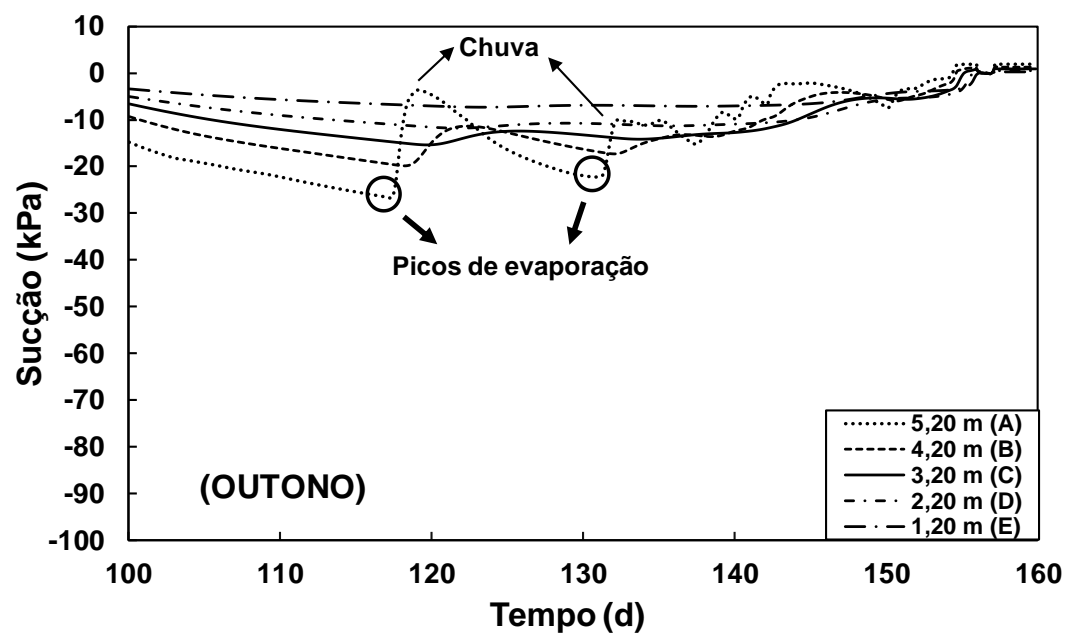

Figura 88 - Sucção versus tempo (outono de 2017)

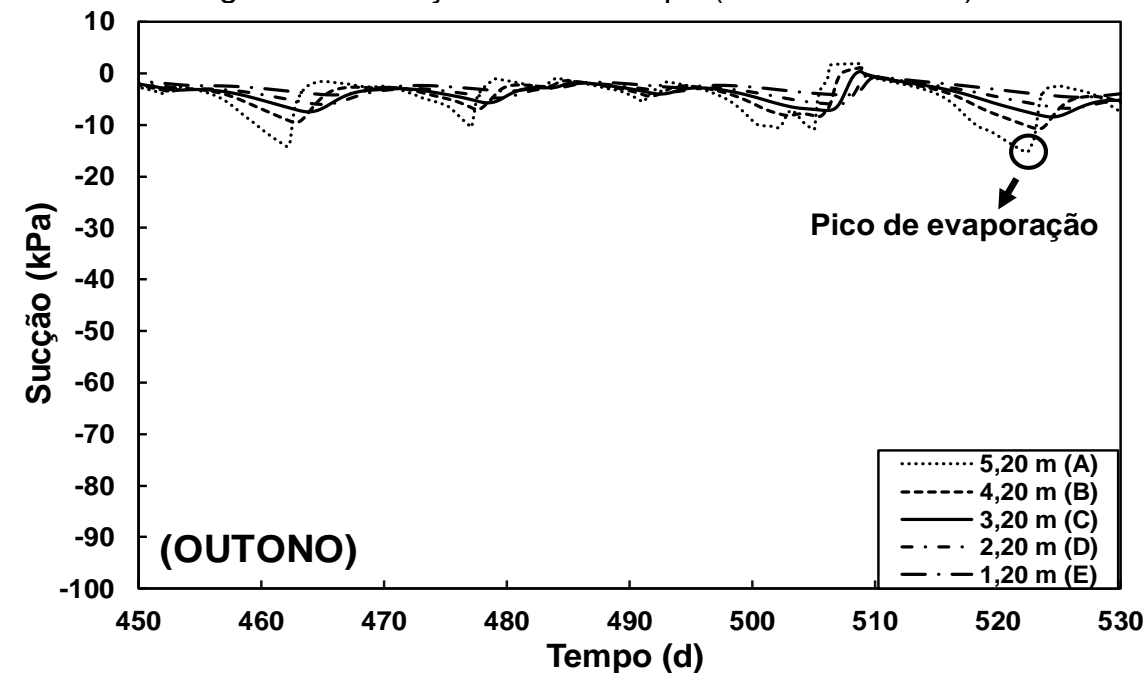

Observou-se que o outono apresenta alguns picos de evaporação, devido ao fato de ser um período de transição entre o verão e o inverno. Sabe-se que o subleito no verão apresenta na maior parte do tempo comportamento hidráulico prejudicado em decorrência da elevada taxa de precipitação, o qual gera um excedente hídrico. Como a taxa de precipitação começa a decrescer nesse período, a evaporação começa a se tornar maior que a precipitação, gerando um déficit hídrico. 


\section{$\underline{\text { Inverno }}$}

As Figuras 89 e 90 apresentam os gráficos dos perfis de sucção em função do tempo no inverno de 2016 e de 2017, respectivamente, quando ocorreu os picos máximos de evaporação.

Figura 89 - Sucção versus tempo (inverno de 2016)

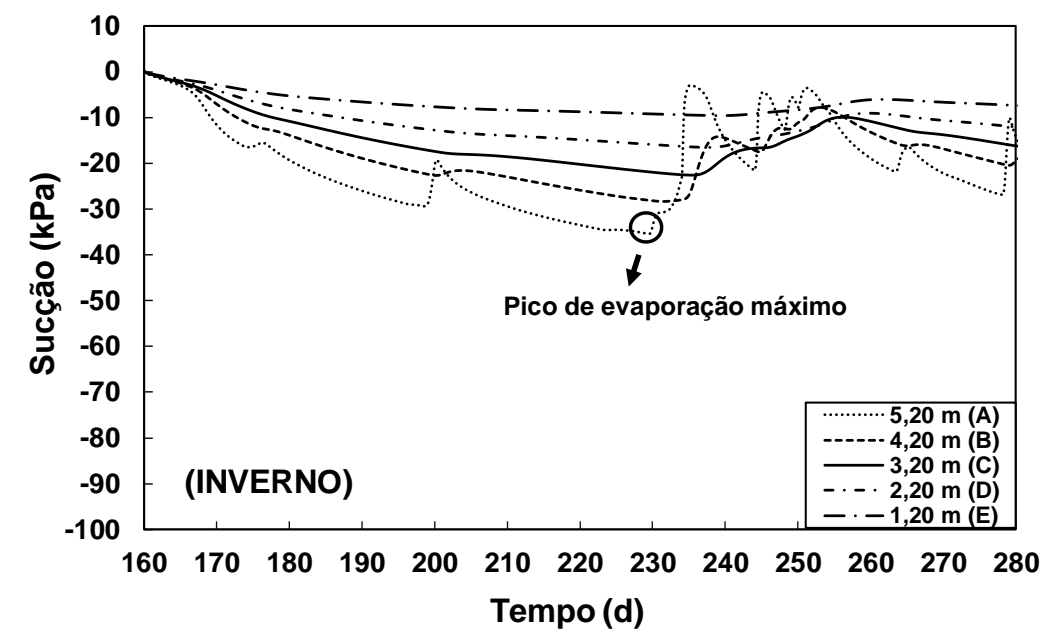

Figura 90 - Sucção versus tempo (inverno de 2017)

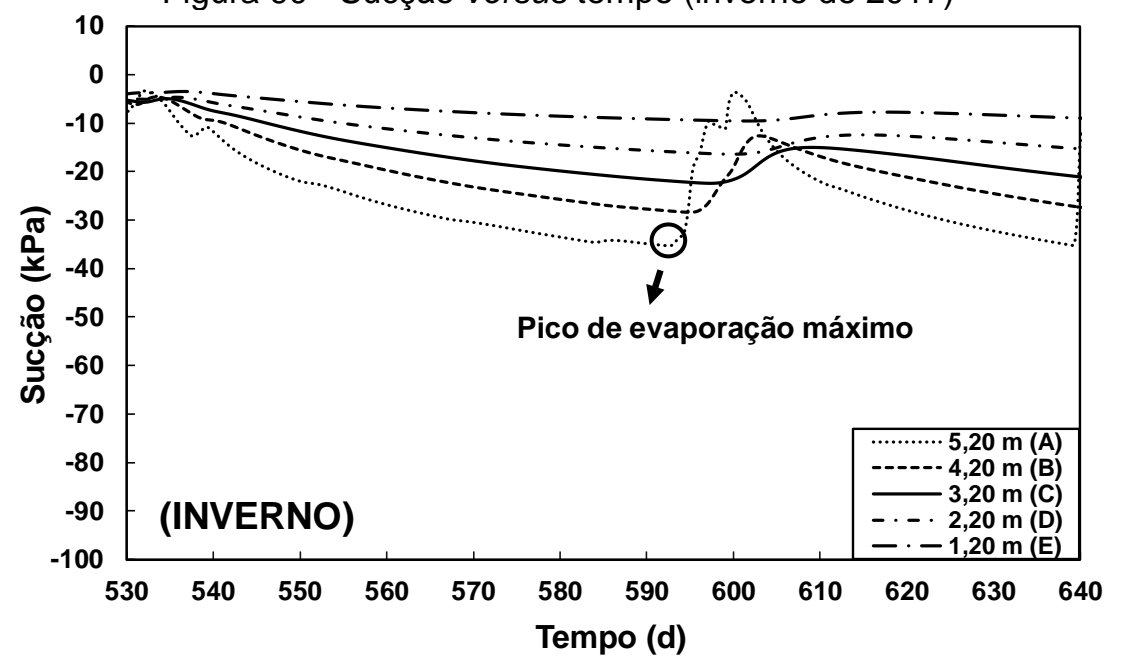

O fenômeno da evaporação em regiões de clima tropical são importantes e devem ser analisados levando em consideração a sua influência nos primeiros metros de profundidade ou próximo à superfície, onde a interação subleito-clima é mais intensa.

O inverno ou estação seca para o clima local, revela a influência do excesso da evaporação sobre a precipitação no perfil de sucção ao longo do tempo. Tal aumento 
de sucção interfere no estado de tensões do solo, aumentando a sua capacidade de carga. Observa-se que, os pontos A $(5,20 \mathrm{~m})$ e B $(4,20 \mathrm{~m})$, os quais estão localizados próximos à superfície do modelo, sofrem maior influência da evaporação quando comparados aos pontos mais distantes (C, D e E).

Desse modo, menores valores de umidade são verificados nas proximidades do topo do subleito, aumentando-se com a profundidade durante o inverno em 2016 e 2017. As Figuras 91 e 92 apresentam o perfil de sucção em função da profundidade para os invernos de 2016 e 2017, respectivamente, com o intuito de analisar a variação dessa variável na superfície do subleito.

Figura 91 - Sucção versus profundidade (inverno de 2016)

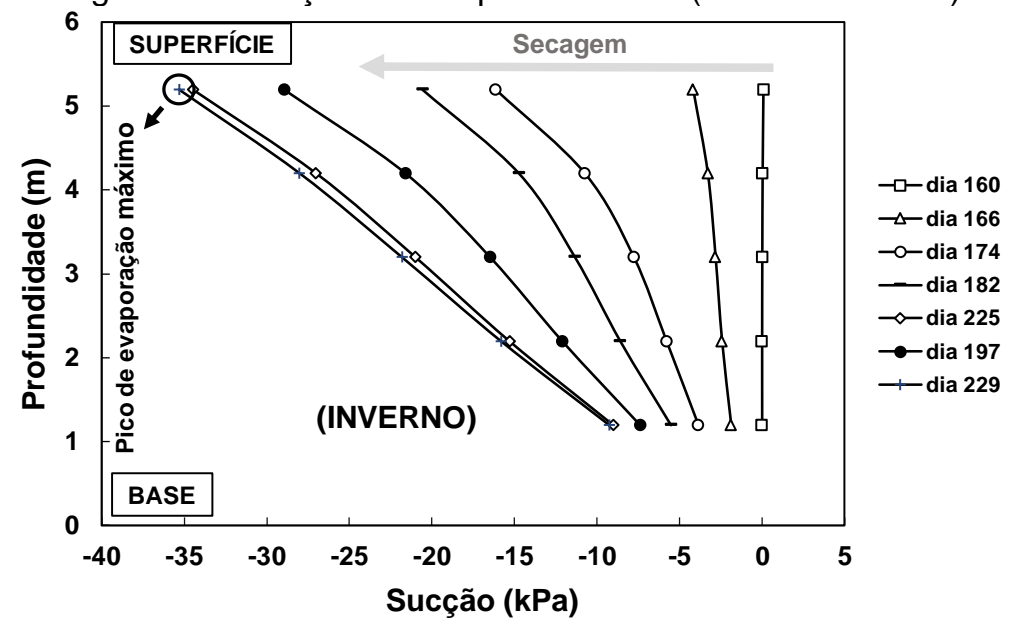

Figura 92 - Sucção versus profundidade (inverno de 2017)

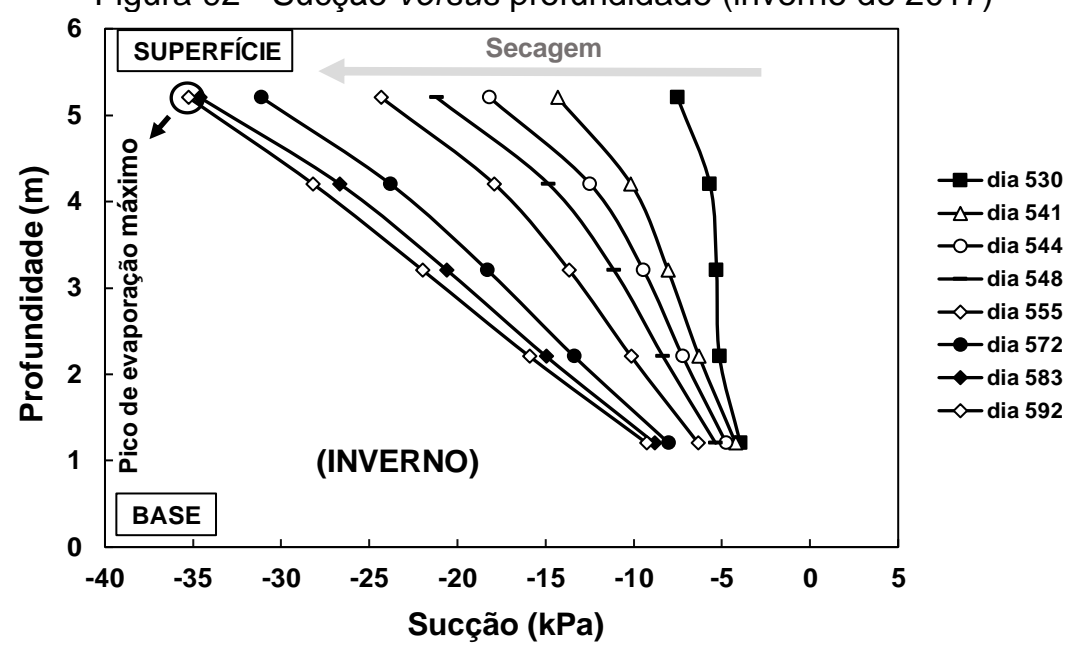

Além disso, o perfil de sucção em função da distância lateral ou transversal foi investigado objetivando-se verificar a influência do lastro, do sublastro e do clima na 
condição de saturação do subleito. Selecionou-se o mesmo intervalo das análises anteriores o qual corresponde a eventos extremos de evaporação. A Figura 93 apresenta a análise do perfil de sucção versus distância transversal.

Figura 93 - Sucção versus distância transversal (inverno de 2016)

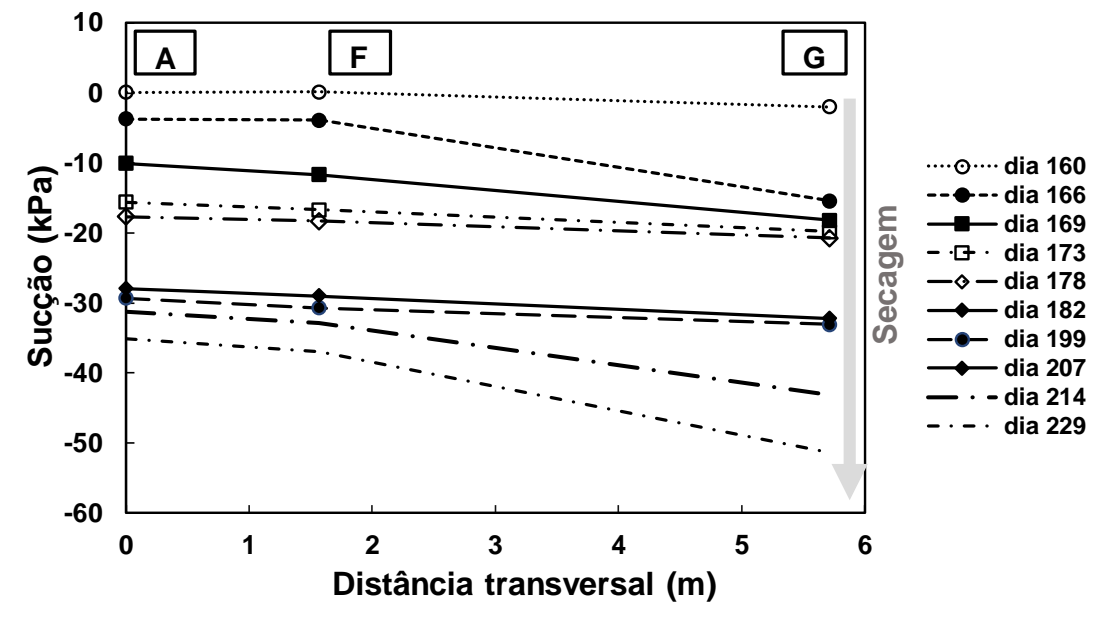

Verificou-se que os pontos do subleito localizados sob a camada de sublastro demonstraram menores valores de sucção ou maiores valores de umidade, quando comparados aos pontos mais expostos às interações via-clima durante ciclos de secagem. Isto esclarece o fato de que o clima aliado as camadas de lastro e sublastro, tende a manter este tipo de solo de subleito com elevada taxa de umidade ( $\mathrm{wot}_{\mathrm{t}}+7 \%$ ) sob a via, mesmo durante períodos de evaporação. A Figura 94 mostra uma ilustração do ciclo de secagem no dia 166 (inverno de 2016).

Figura 94 - Exemplo do processo de secagem no perfil da via

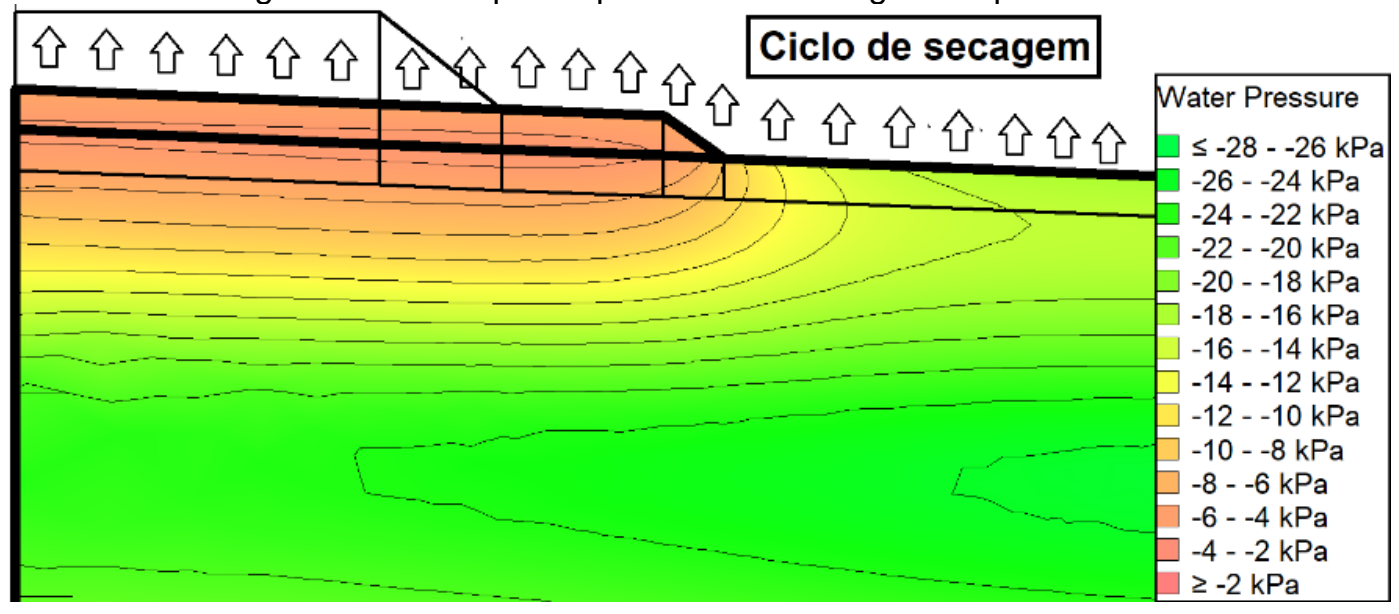


A partir das simulações numéricas, sabe-se que o inverno é a estação mais seca de maiores taxas de evaporação, e consequentemente, de maiores valores de sucção alcançados pelo subleito, o que pode favorecer seu comportamento mecânico. Apesar disso, alguns eventos de precipitação também podem ocorrer após períodos secos, fazendo com que o solo saia em um curto intervalo de tempo da condição não saturada para a condição saturada, podendo afetar o desempenho da via permanente e, assim, sua eficiência.

Ou seja, o solo sai de uma condição favorável em termos de resistência e deformabilidade devido à presença da sucção, para uma condição desfavorável, quando o mesmo perde essa variável de tensão fundamental para o comportamento mecânico do solo, em função da saturação dos seus poros com água.

Considerando-se o que foi exposto, ciclos de umedecimento do dia 228 ao 235 (7 dias de duração) e do dia 592 ao 600 (8 dias de duração) foram analisados com o intuito de se verificarem as consequências de eventos chuvosos durante o inverno de 2016 e 2017, respectivamente, logo após ciclos de secagem extremos.

Tais ciclos extremos de secagem foram considerados, possivelmente, os mais favoráveis ao comportamento mecânico do solo para o clima local após deixar a sua condição de compactação inicial, em decorrência do aumento dos valores da tensão de sucção. As Figuras 95 e 96 demonstram os períodos de umedecimento analisados durante o inverno em 2016 e 2017.

Figura 95 - Fenômeno de umedecimento do subleito no inverno de 2016 após evento chuvoso

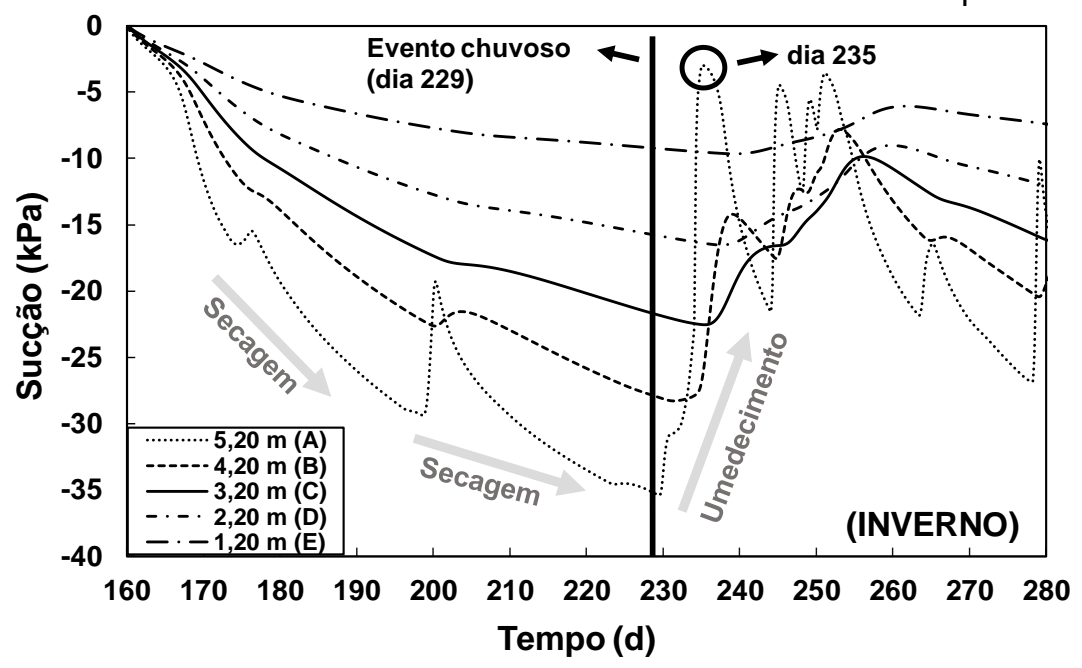


Figura 96 - Fenômeno de umedecimento do subleito no inverno de 2017 após evento chuvoso

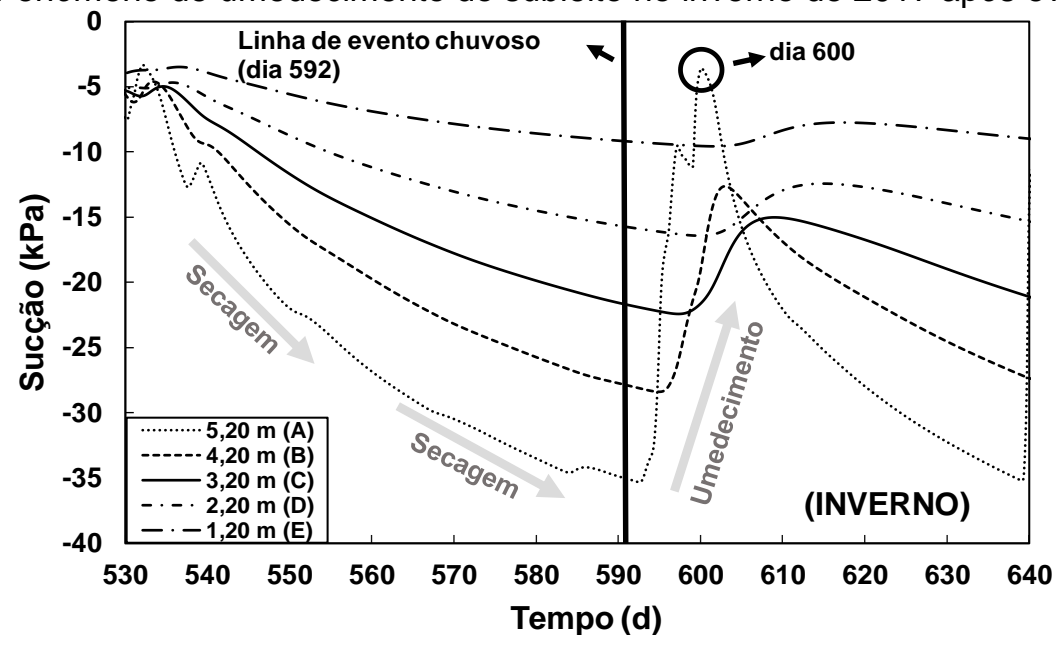

Verificou-se que com relação ao ano de 2016, uma precipitação acumulada de $43 \mathrm{~mm}$ do dia 229 ao 235, provocou um decréscimo dos valores de sucção nos pontos $A, B$, C, D e E, de $35 \mathrm{kPa}$ para 2,5 kPa, aproximadamente. Já no ano de 2017, $47 \mathrm{~mm}$ de precipitação foram necessários para ocasionar o decréscimo acentuado nos valores de sucção do solo.

Isso pode contribuir para a deterioração do comportamento mecânico do solo de subleito, à medida que, a elevação do seu teor de umidade aliada aos altos valores de cargas cíclicas pode provocar o aumento da sua taxa de deformabilidade. Considerando-se a análise da variação dos valores de sucção em profundidade, após o subleito ter sido submetido à processos de umedecimento, foram plotados os respectivos gráficos para o ano de 2016 e 2017 (Figuras 97 e 98).

Figura 97 - Chuva de inverno em 2016

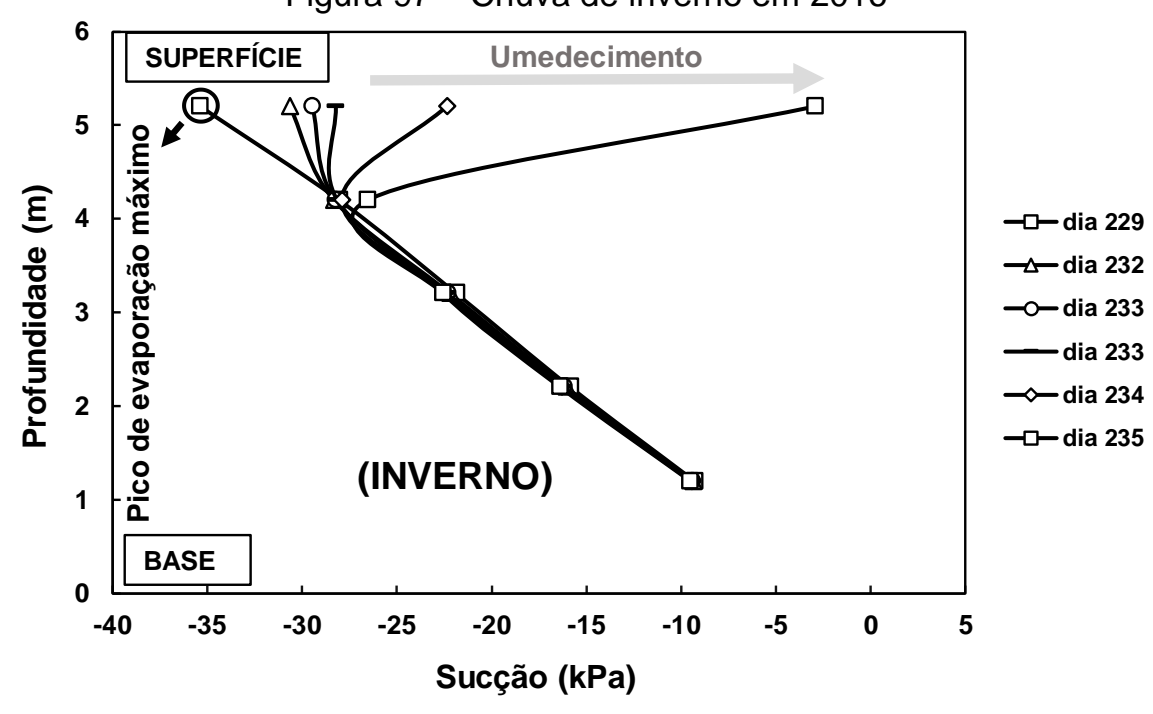


Figura 98 - Chuva de inverno em 2017

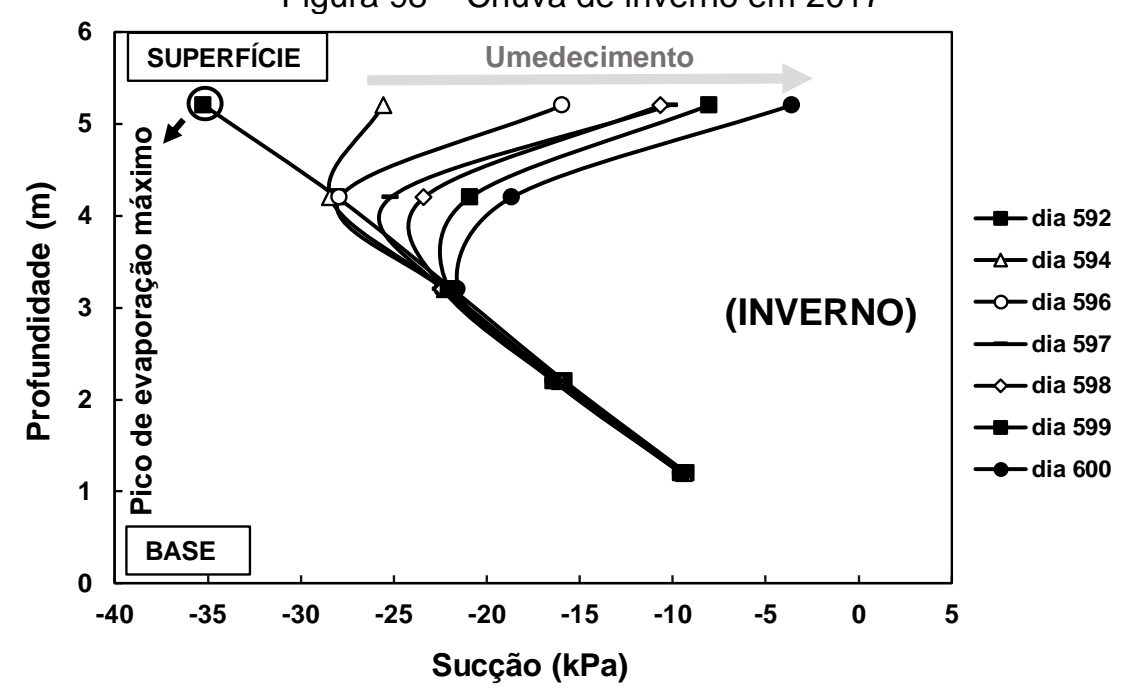

Verifica-se que para o ano de 2016 e 2017, assim como o processo de secagem provocado pela evaporação, os pontos nas proximidades da superfície do subleito são mais sensíveis à ação da precipitação. Porém, no ano de 2017, observa-se que a condição de saturação do subleito é alcançada mais lentamente, o que proporciona mais tempo para a água infiltrar e, consequentemente, alcançar maiores profundidades. Isso aconteceu devido a maior taxa de precipitação diária acumulada ocorrida no ano de 2016, quando comparada ao ano de 2017, para o intervalo de tempo de 6 dias. A Tabela 16 apresenta a precipitação acumulada diária e total, para os primeiros 6 dias de umedecimento do inverno de 2016 e 2017.

Tabela 16 - Precipitação diária acumulada após evaporação máxima

\begin{tabular}{|c|c|c|c|c|c|}
\hline \multicolumn{6}{|c|}{ Ano } \\
\hline \multicolumn{3}{|c|}{2016} & \multicolumn{3}{|c|}{2017} \\
\hline Dia & $\begin{array}{l}\text { Precipitação diária } \\
(\mathrm{mm})\end{array}$ & $\begin{array}{l}\text { Precipitação total } \\
\qquad(\mathrm{mm})\end{array}$ & Dia & $\begin{array}{l}\text { Precipitação diária } \\
(\mathrm{mm})\end{array}$ & $\begin{array}{c}\text { Precipitação total } \\
\text { (mm) }\end{array}$ \\
\hline 229 & 4,65 & \multirow{7}{*}{43,26} & 592 & 1,93 & \multirow{7}{*}{30,04} \\
\hline 230 & 0,15 & & 593 & 0,91 & \\
\hline 231 & 1,2 & & 594 & 6,99 & \\
\hline 232 & 2,56 & & 595 & 5,01 & \\
\hline 233 & 3,98 & & 596 & 7,8 & \\
\hline 234 & 28,83 & & 597 & 4,1 & \\
\hline 235 & 1,89 & & 598 & 3,3 & \\
\hline
\end{tabular}

A Tabela 16 demonstra que, apesar de o clima de 2016 e 2017 serem similares por serem da mesma região de estudo e proporcionarem a mesma tendência com relação 
ao comportamento hidráulico do subleito, a quantidade e a intensidade da chuva diária podem ser diferentes.

Verifica-se que somente no dia 234 do ano de 2016, houve uma taxa de precipitação de aproximadamente $30 \mathrm{~mm}$, a qual provocou a rápida saturação do subleito. Ou seja, a precipitação pode deteriorar o subleito em duas situações: (i) chuvas intensas; e (ii) chuvas duradouras. Isso também pode ser observado, através de outro ângulo, nos gráficos da variação dos perfis de sucção em relação à distância transversal (Figuras 99, 100 e 101).

Figura 99 - Sucção versus profundidade após evento chuvoso no inverno de 2016

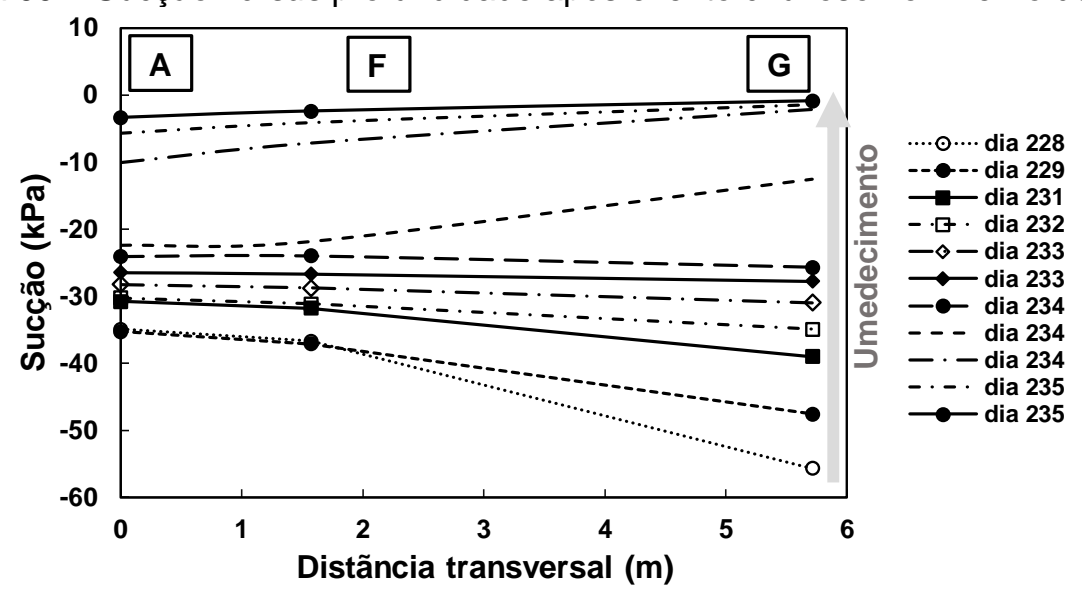

Figura 100 - Sucção versus profundidade após evento chuvoso no inverno de 2017

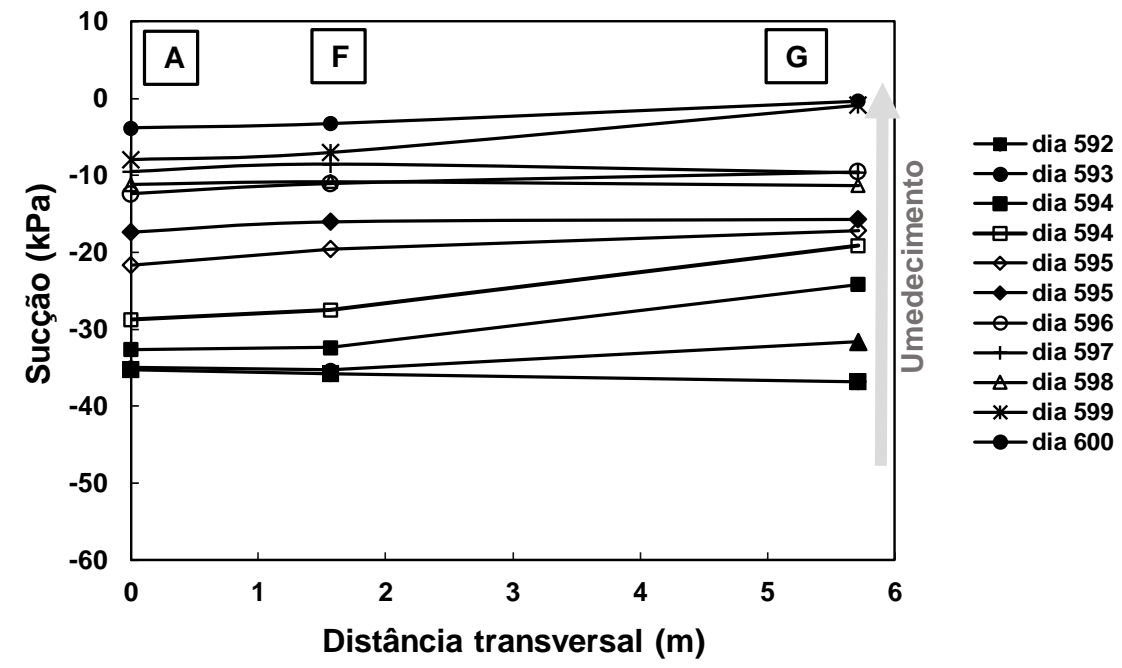

Como já foi comentado, sabe-se que os pontos de análise localizados embaixo da via, ou seja, cobertos pelo lastro e sublastro, são menos impactados pelas variações 
climáticas. Porém, nesse caso verifica-se que, a influência do clima é maior no inverno de 2016 quando comparado ao de 2017, em decorrência da diferença da taxa de precipitação entre ambos. Isso pode gerar uma deterioração mais rápida do subleito devido a sua região exposta, ser um meio pelo qual pode-se propagar a infiltração de água na região protegida.

Figura 101 - Exemplo do ciclo de umedecimento após período chuvoso em 2016

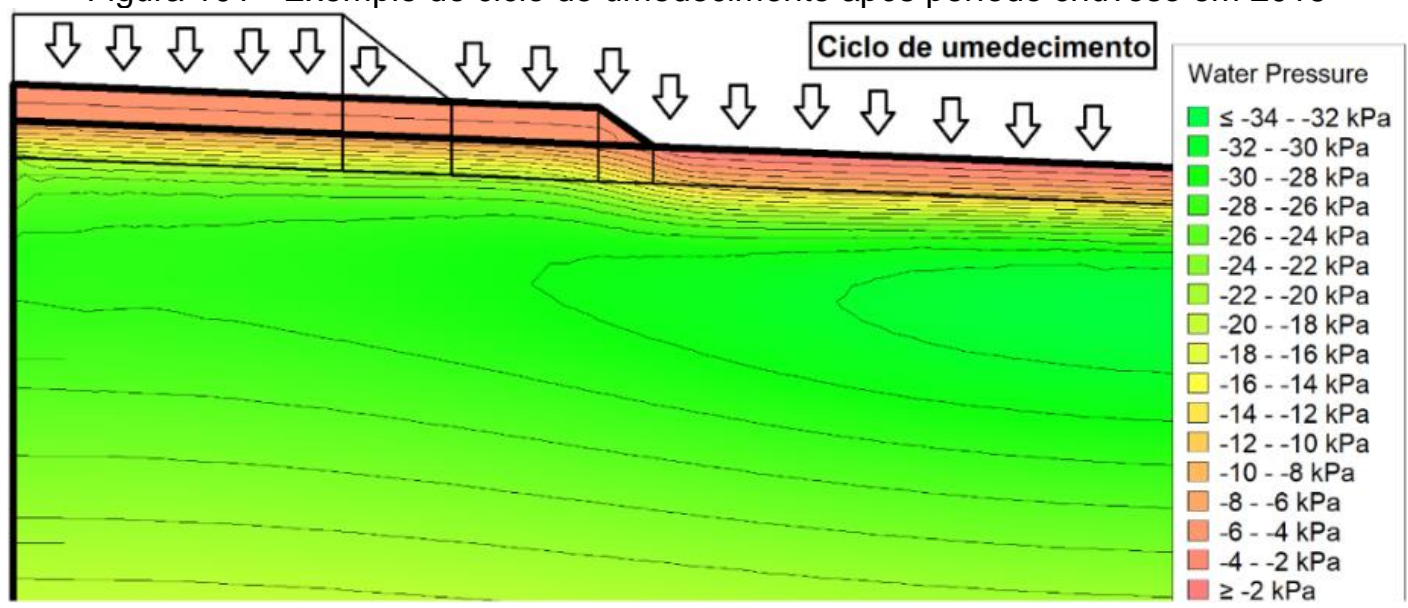

\section{Primavera}

As Figuras 102 e 103 apresentam os gráficos da variação da sucção em função do tempo para a primavera de 2016 e 2017 , respectivamente.

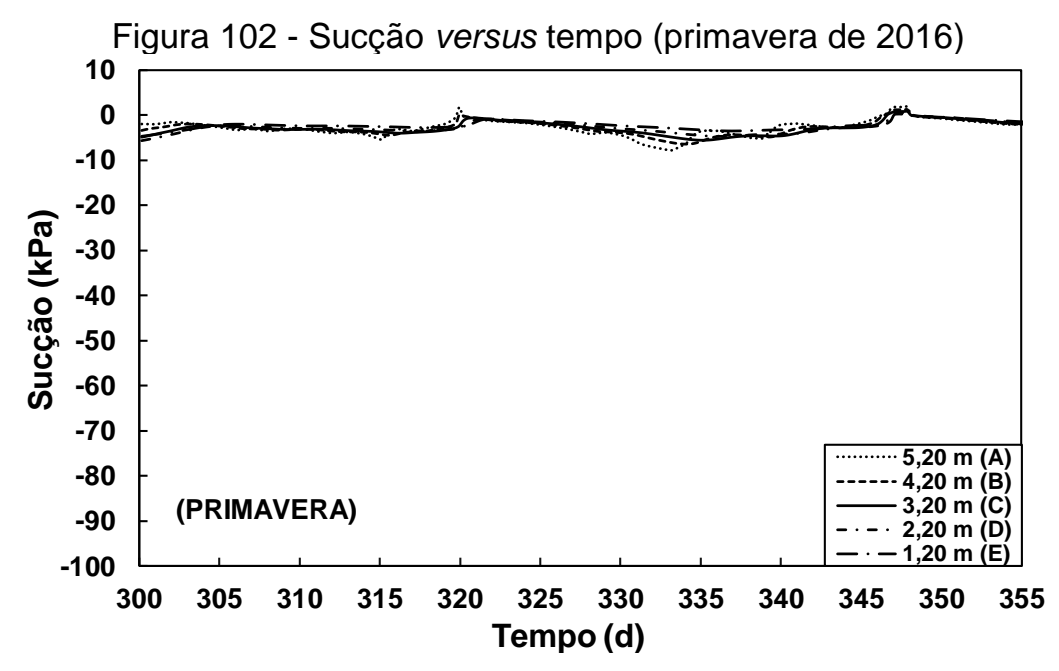


Figura 103 - Sucção versus tempo (primavera de 2017)

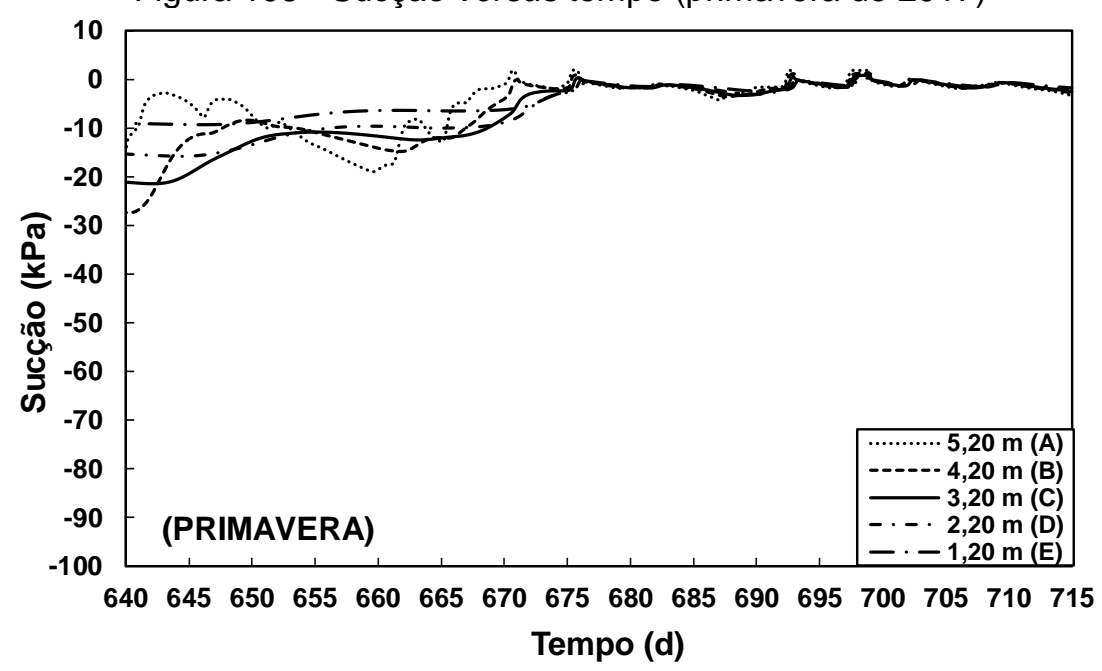

Verifica-se que, assim como outono é a estação de transição do verão para o inverno, a primavera é a estação de transição do inverno para o verão. Nesta estação, as taxas de precipitação começam a elevar-se enquanto que a taxa de evaporação decresce, aumentando o excedente hídrico. Desse modo, observa-se a partir dos gráficos apresentados, que durante o verão e a primavera, o solo tende a voltar para a sua condição saturada, com valores de sucção tendendo a $0 \mathrm{kPa}$.

\subsection{4 - Umidade de equilíbrio do subleito ao longo de três anos}

Apesar da importância da análise do subleito em função de cada ano com seus respectivos dados climáticos, foram avaliadas simulações numéricas considerandose dados climáticos referente a um ano em particular, por três anos (Figura 104).

Figura 104 - Sucção versus tempo em três anos para os dados climáticos de 2016

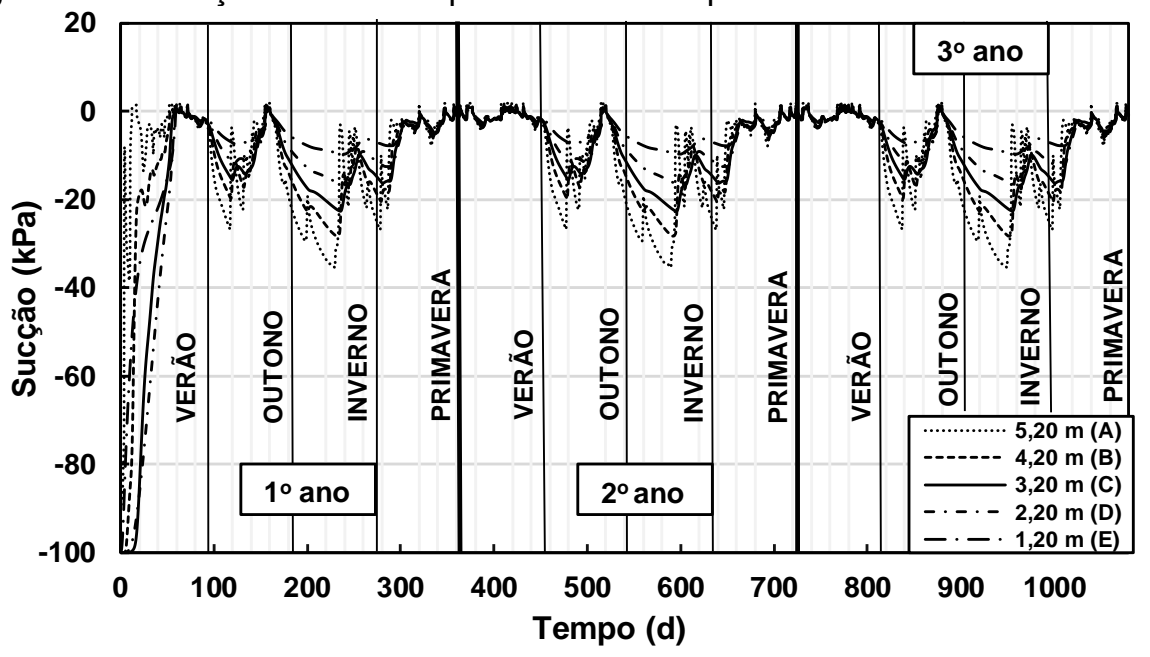


Com base no gráfico acima, verificou-se que, em decorrência das condições climáticas, existe uma tendência que, depois do segundo ano, os níveis de sucção média permanecem os mesmos, aproximadamente. Em outras palavras, a condição inicial do material não é atingida novamente e, os valores de sucção os quais estão relacionados com os valores de umidade, estão propensos a ocorrerem nas mesmas estações ao longo dos anos.

\subsection{5 - A influência da época de compactação e das características hidráulicas do subleito no seu comportamento hidráulico}

\section{Época e condição de compactação}

Foram apresentados até o momento, os dados provenientes das simulações do modelo numérico, considerando-se o subleito da via permanente compactado no verão, ou seja, período úmido ou chuvoso. Desse modo, afim de verificar a influência da época de compactação do solo no comportamento hidráulico do perfil da via, realizaram-se análises referente ao subleito compactado no inverno ou estação seca. Além disso, decidiu-se variar a condição de compactação inicial do mesmo, aplicandose sucções iniciais correspondentes à umidade ótima e 6\% acima da ótima (Figuras 105 e 106).

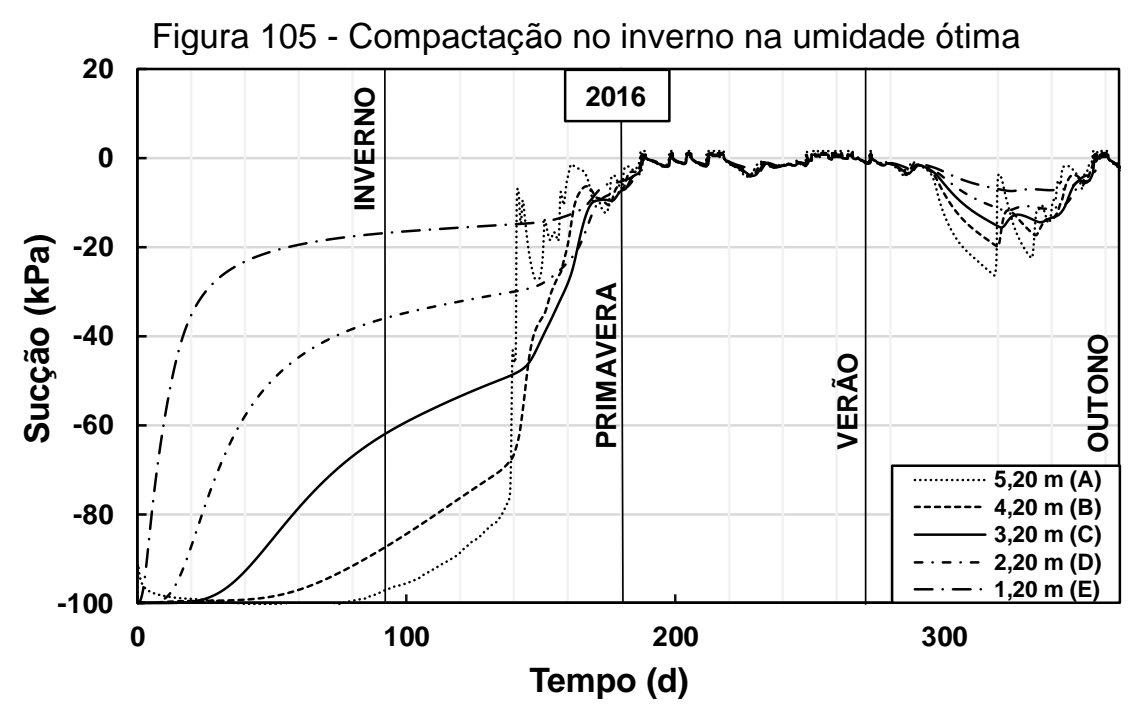


Figura 106 - Compactação no inverno com 6\% acima da umidade ótima

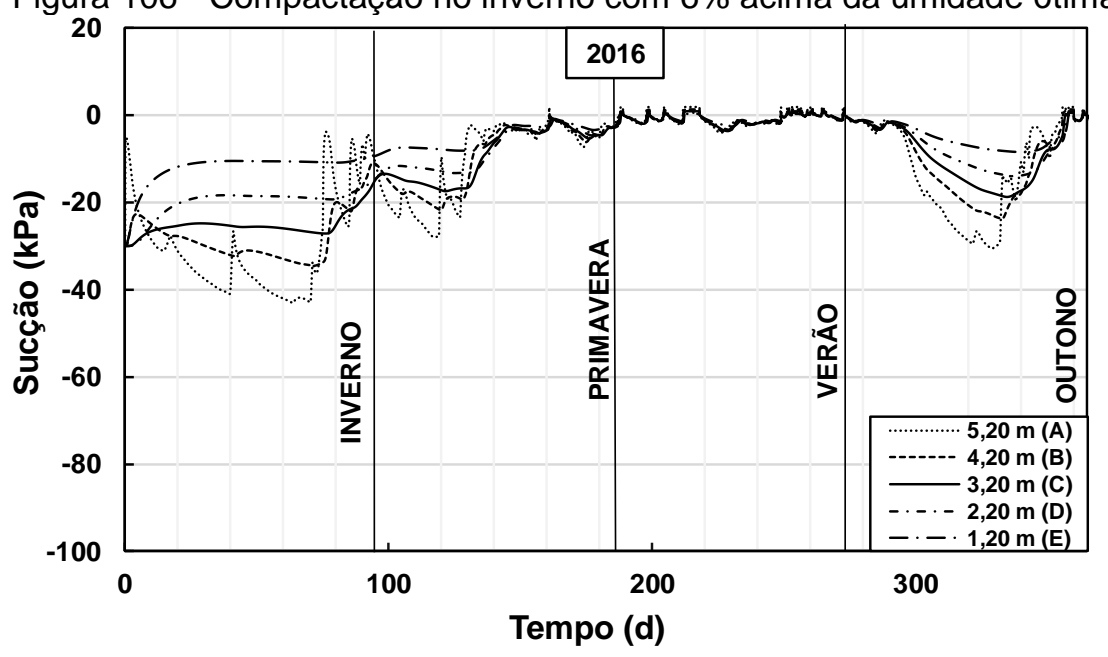

Verificou-se que, para o clima e o solo abordados nesse estudo, a compactação do subleito em diferentes estações do ano ou em diferentes umidades iniciais, influenciam a sua condição de saturação e o seu estado de tensões (sucção). Ressalta-se que, o inverno, por ser a estação mais seca, tende a manter o topo do subleito com valores de umidade próximos a sua condição ótima por 5 meses, até a primavera, quando o mesmo tende a saturar e atingir o estado de equilíbrio com o clima. Isso pode postergar a realização de manutenções, considerando que o subleito em condições de elevado grau de saturação, tem o potencial de deformar e provocar a perda de geometria. Já o cenário oposto, de compactação durante o verão ou período mais úmido (item 4.2.2), compromete a condição de saturação do subleito em apenas 5 dias, antes de alcançar o equilíbrio.

Entretanto, a época e a condição de compactação influenciam o comportamento hidráulico do subleito somente a curto prazo, pois o mesmo é bastante sensível a presença de água. Além disso, o sublastro granular utilizado, não cumpriu a sua função de drenagem a longo prazo, contribuindo ainda mais para os baixos valores de sucção alcançados pelo solo. Considerando-se esse mesmo solo, porém com um sublastro de baixa permeabilidade, ou um outro cenário com um subleito menos sensível a presença de água em um clima mais seco, a compactação do subleito na umidade ótima ou abaixo dela durante a estação seca, pode ser uma solução para preservar níveis de sucção elevados durante as três estações do ano restantes. Ferreira e Teixeira (2012) concluíram que, a utilização de um sublastro betuminoso ao invés de um granular, resulta em reduções significativas da variação do grau de 
saturação do subleito, mantendo-o com baixos valores de umidade ao longo do ano e, consequentemente, reduzindo sua deformabilidade ao longo do tempo.

\section{Curva característica}

Além da curva característica determinada em laboratório para o solo de campo, classificado como siltoso, foram simulados outros possíveis cenários, variando-se os parâmetros $\alpha, \mathrm{n}$ e $\mathrm{m}$ da mesma e mantendo-se a permeabilidade, a fim de representar solos arenosos e argilosos com baixos e elevados valores de entrada de ar, respectivamente (Figura 107).

Figura 107 - Sucção versus tempo para diferentes tipos de solo

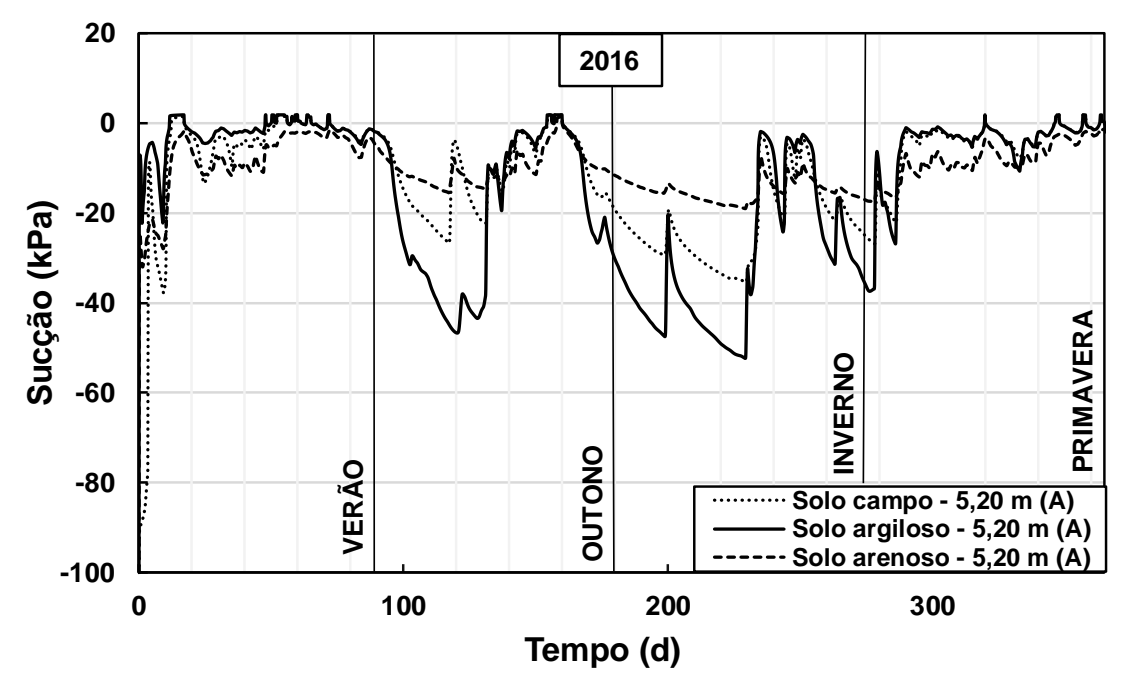

Observou-se que, considerando-se o ponto localizado no topo do subleito, caso fosse aplicado um solo mais arenoso como material de subleito da via em questão, o mesmo tenderia a atingir baixos valores de sucção e, então, pelo fato de serem mais permeáveis e possuírem menor capacidade de retenção de água, sendo menos sensíveis aos eventos extremos de evaporação e umedecimento ocasionados pelo clima da região. Por outro lado, solos mais argilosos ou com maior capacidade de retenção de água tendem a atingirem maiores valores de sucção quando submetidos a eventos de secagem, em decorrência da sua menor permeabilidade e menores dimensões dos poros. Em outras palavras, a aplicação de solos mais argilosos seria mais adequada para o clima estudado. 


\subsection{6 - A influência da variação das condições hidráulicas e geométricas do sublastro no comportamento hidráulico do subleito}

\section{$\underline{\text { Permeabilidade da camada }}$}

Foram analisados diferentes cenários considerando-se a variação da permeabilidade do sublastro, com o intuito de se verificar a sua influência no comportamento hidromecânico do subleito. As Figuras 108, 109 e 110 apresentam análises da variação da sucção em função do tempo para o sublastro granular com permeabilidade de $3,66 \times 10^{-4}, 3,66 \times 10^{-6}$ e $3,66 \times 10^{-8} \mathrm{~m} / \mathrm{s}$, respectivamente.

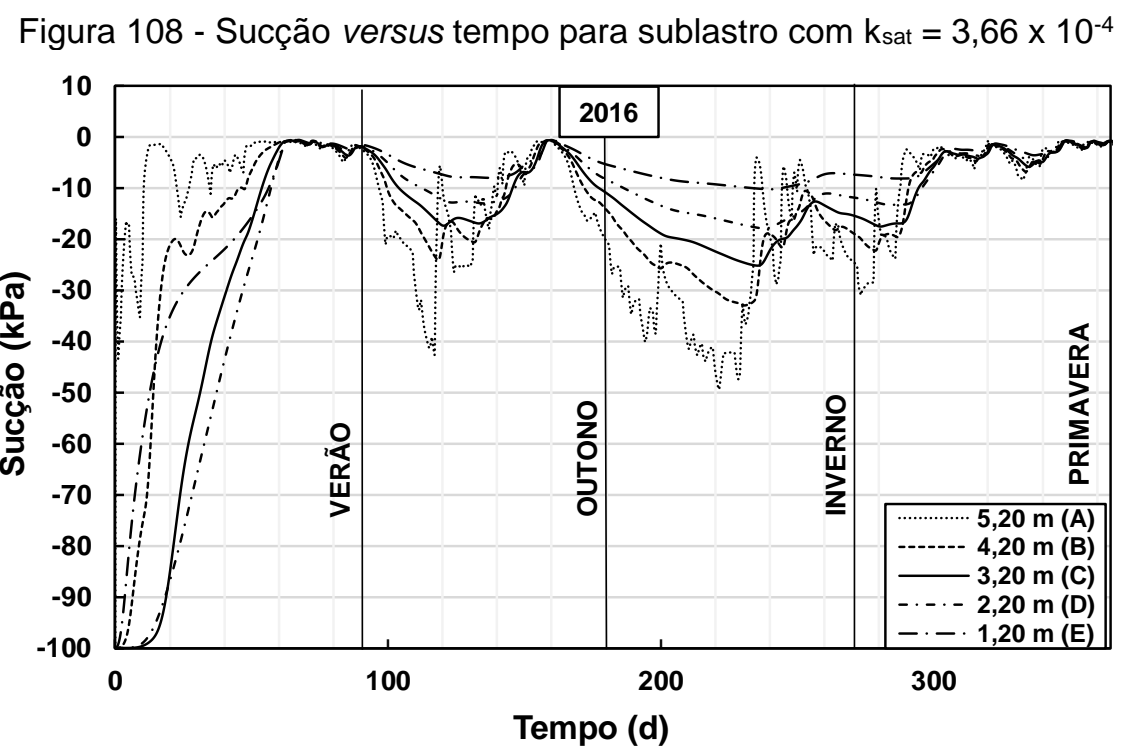

Figura 109 - Sucção versus tempo para sublastro com $\mathrm{k}_{\text {sat }}=3,66 \times 10^{-6}$

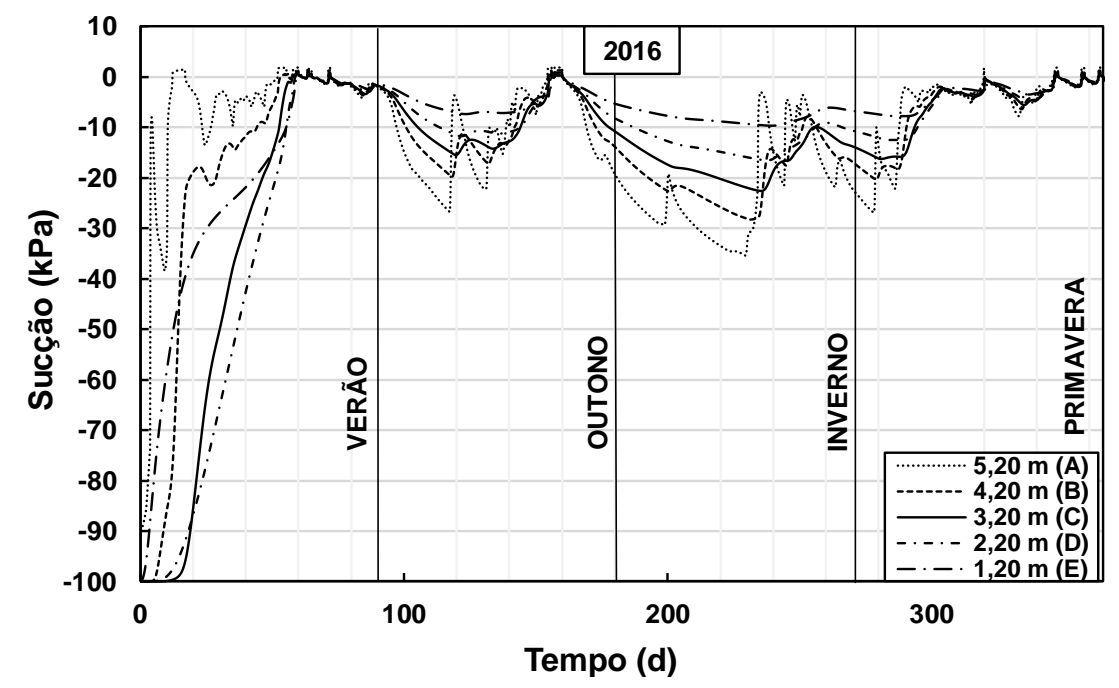


Figura 110 - Sucção versus tempo para sublastro com ksat $=3,66 \times 10^{-8}$

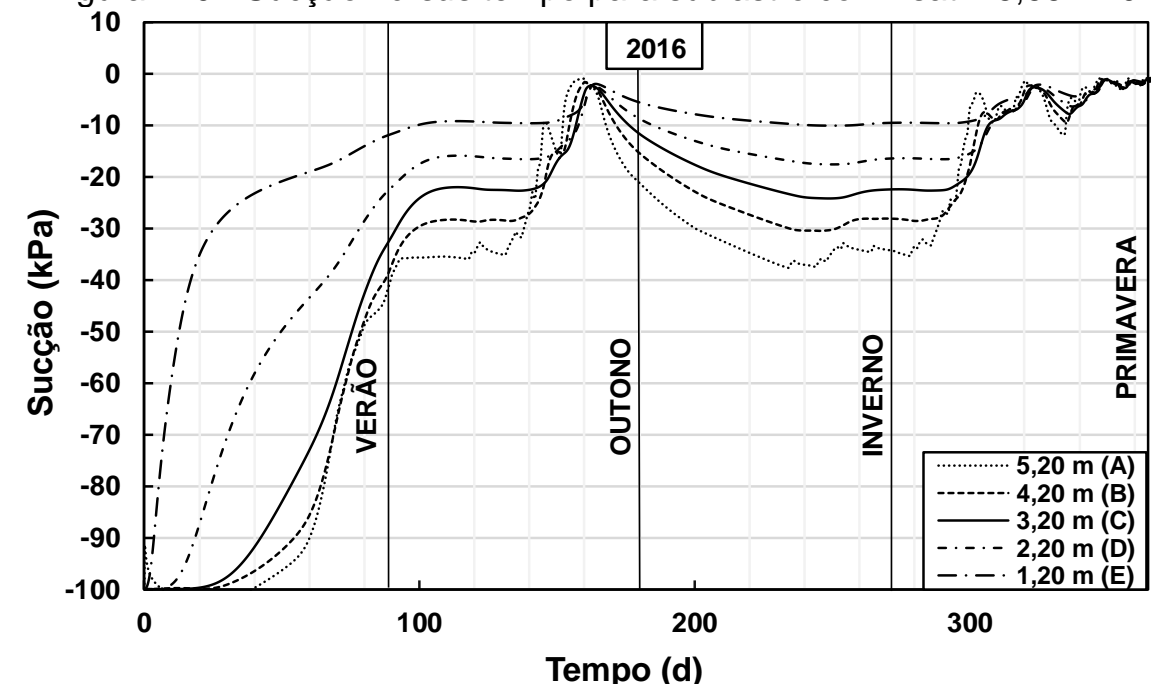

Verificou-se que, a variação da permeabilidade da BGS como sublastro granular, ocasiona variações na tensão de sucção do subleito abaixo dela. Uma BGS mais permeável ou com menores valores de massa específica aparente seca, torna o subleito mais sensível a variações sazonais, pois durante períodos de evaporação, o solo de subleito alcança maiores valores de sucção, quando comparado às condições onde a BGS é menos permeável, o que pode contribuir para um melhor comportamento mecânico do subleito.

Por outro lado, durante períodos de precipitação, uma camada de sublastro menos compacta pode provocar a saturação do subleito e uma possível deterioração do seu comportamento mecânico. Dessa forma, ressalta-se a importância, não somente dos eventos de precipitação, como também da evaporação no comportamento hidráulico do subleito, evidenciando que o conhecimento do comportamento do solo quanto ao seu ciclo de umedecimento e secagem em função do clima, deve ser aplicado na escolha dos materiais geotécnicos da via.

\section{Curva característica}

Foram realizadas simulações considerando possíveis variações na curva característica do sublastro granular, ou seja, no valor da sua umidade residual. Tais análises se basearam no fato de que Perera et al. (2005), comentaram que a umidade residual de materiais granulares não plásticos e não coesivos para pavimentação, 
correspondia a $100 \mathrm{kPa}$. Dessa forma, a Figura 111 apresenta uma comparação entre a variação de sucção em função do tempo para os dois cenários.

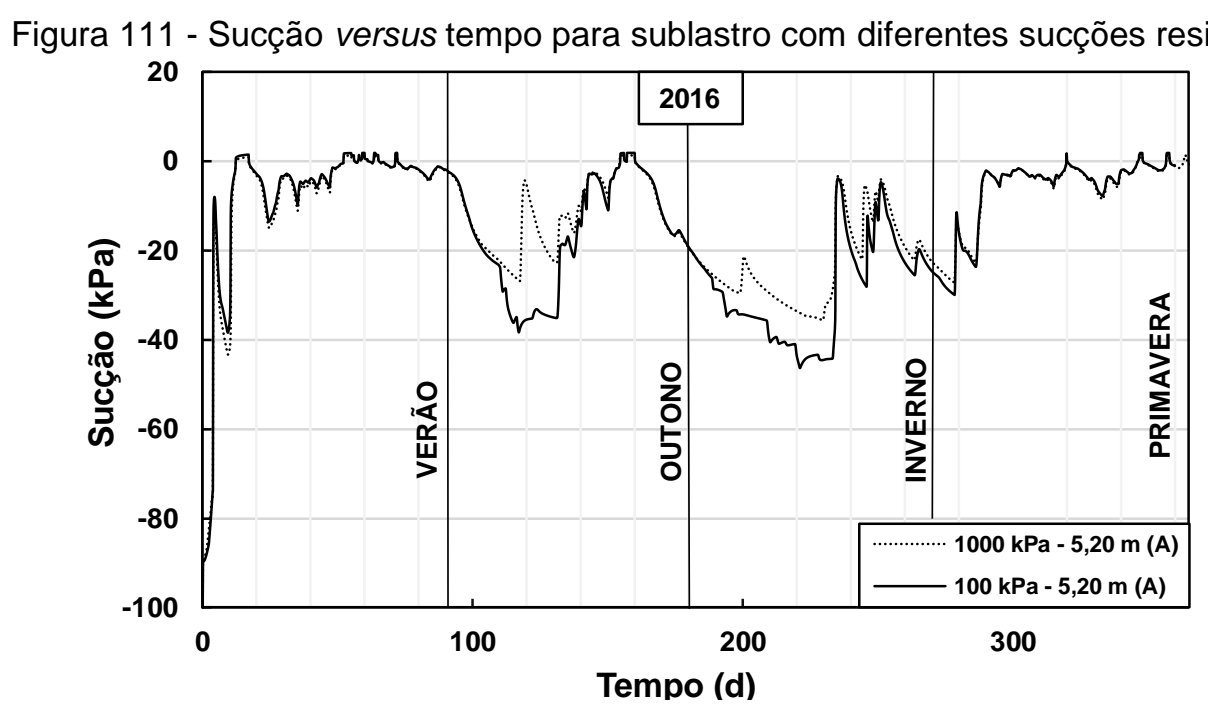

Verificou-se que a variação da umidade residual da curva de retenção da BGS, de 1000 para $100 \mathrm{kPa}$, provoca um aumento nos valores de sucção durante o inverno. Isso evidencia que, quanto menor for a umidade residual do sublastro granular aplicado, maior será a condutividade hidráulica não saturada, possibilitando assim maior fluxo. Dessa forma, se a umidade residual tiver uma variação de $1000 \mathrm{kPa}$ para $100 \mathrm{kPa}$, o solo de subleito abaixo da BGS, atingirá valores de sucção mais elevados, ou seja, o solo estará mais susceptível a influência climática ou menos protegido.

Além disso, adotando-se tanto os dados da curva granulométrica quanto da umidade volumétrica saturada do sublastro de campo (faixa C) e da BGS utilizada por Virgiliis (2013) (faixa B) no modelo numérico, os resultados de sucção em função do tempo foram iguais. Isso ocorreu devido ao fato de que os valores de massa específica aparente seca de ambos são muito próximos, resultando em características de permeabilidade e de retenção de água semelhantes, confirmando os valores iguais de permeabilidade calculados por Suzuki et al. (2013) através da equação de Moulton (1980) para BGS nas faixas B e C. 


\section{Umidade de compactação}

Foram adotadas diferentes umidades de compactação para a BGS considerando-se os dados de compactação obtidos em laboratório comentados no item 4.1.1, tais como $3 \%$ e de $7 \%$, com o intuito de verificar se o sublastro granular de BGS compactado em diferentes condições, pode influenciar no comportamento hidráulico do subleito para o clima e solo locais (Figura 112).

Figura 112 - Sucção versus tempo para diferentes condições de compactação do sublastro

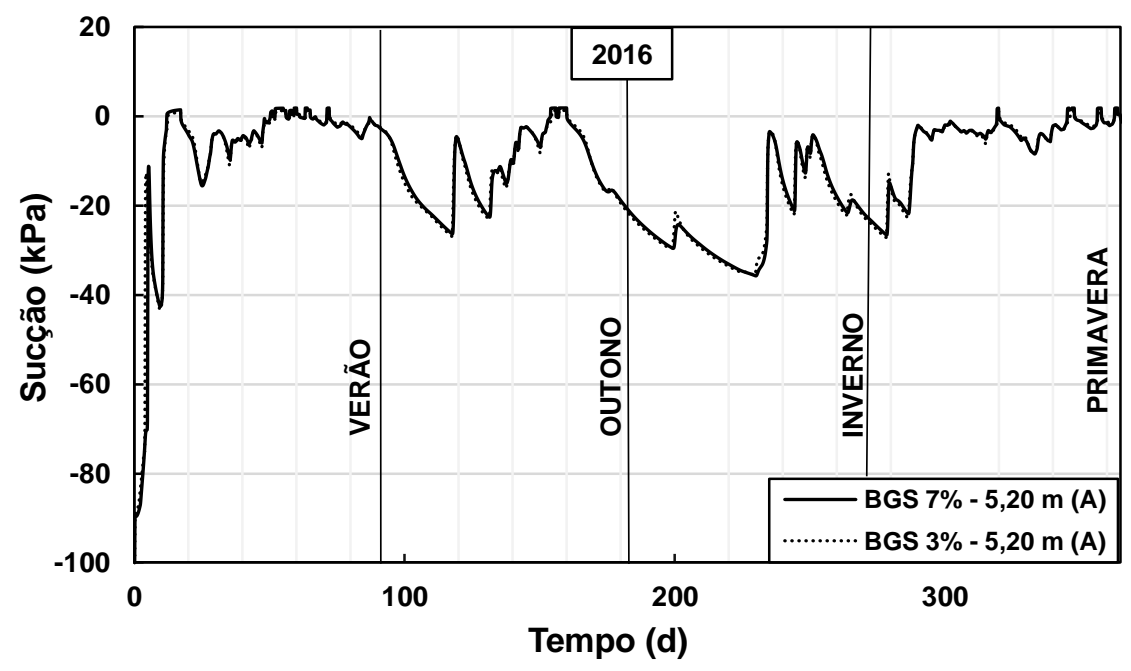

Diante dos resultados da variação de sucção em função do tempo para diferentes condições de compactação do sublastro, verificou-se que ambos os cenários não geram variações significativas da umidade do subleito em função do clima, tornando os valores de sucção praticamente constantes. Isso evidencia que o maior influenciador nessas condições é o clima.

\section{Extensão da camada}

A partir de observações de campo, pôde ser observado variações na extensão transversal do material de sublastro granular construído na via permanente, compreendendo distâncias laterais de até $5 \mathrm{~m}$, do eixo da via. Considerando-se que a extensão transversal total do modelo é de $7,5 \mathrm{~m}$, decidiu-se analisar a variação da infiltração no perfil da via permanente, considerando-se o sublastro com as seguintes 
dimensões (Figura 113): (i) 3,50 m (curto); (ii) 5,80 m (médio); (iii) 7,50 m; e (iv) 0 m (sem sublastro).

Figura 113 - Sucção versus tempo para diferentes extensões do sublastro granular de BGS

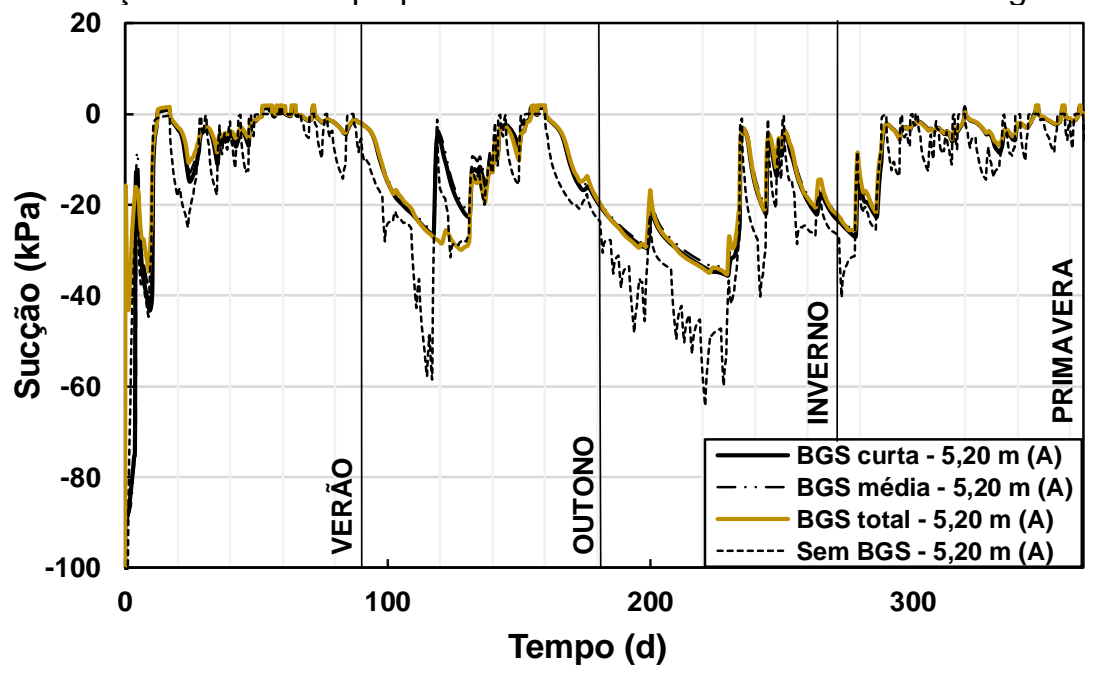

A partir da comparação dos cenários expostos acima, verificou-se que para uma mesma permeabilidade saturada da BGS, aumentando-se sua extensão lateral (área de cobertura), não ocorrem mudanças significativas nos valores de sucção do subleito ao longo do ano, tendendo aos mesmos valores de umidade de equilíbrio. Em períodos de intensa evaporação, o solo completamente exposto, ou seja, sem nenhum tipo de camada de proteção, atinge valores elevados de sucção, em direção a sua condição inicial de compactação, diferentemente do cenário com sublastro. Isso evidencia que nem sempre uma camada protetora sobre o subleito pode proporcionar uma melhora na sua condição de saturação, pois como pode ser observado, uma camada protetora pode dificultar o processo de evaporação, considerado prejudicial para o comportamento mecânico do solo, pois contribui para o acúmulo de água no subleito.

No caso do solo completamente coberto por um sublastro, as características hidráulicas dessa camada irão comandar a interação subleito-clima, considerando-se que, quanto mais permeável ela se comportar, maior será a sensibilidade do solo às variações de umidade, assim como a tendência de retornar a sua condição inicial. Além disso, quanto menos permeável a camada de sublastro se apresentar, maior é o obstáculo para o fluxo de água. Ou seja, valores de permeabilidade elevados podem 
tanto aumentar o escoamento superficial e diminuir a infiltração, como também diminuir a evaporação de água do solo.

\section{Espessura}

Diante da análise dos fatores geotécnicos e climáticos que podem influenciar no comportamento hidráulico do subleito ferroviário em questão, foram analisados diferentes cenários com relação a espessura da camada de sublastro (Figura 114).

Figura 114 - Sucção versus tempo para diferentes espessuras de sublastro granular

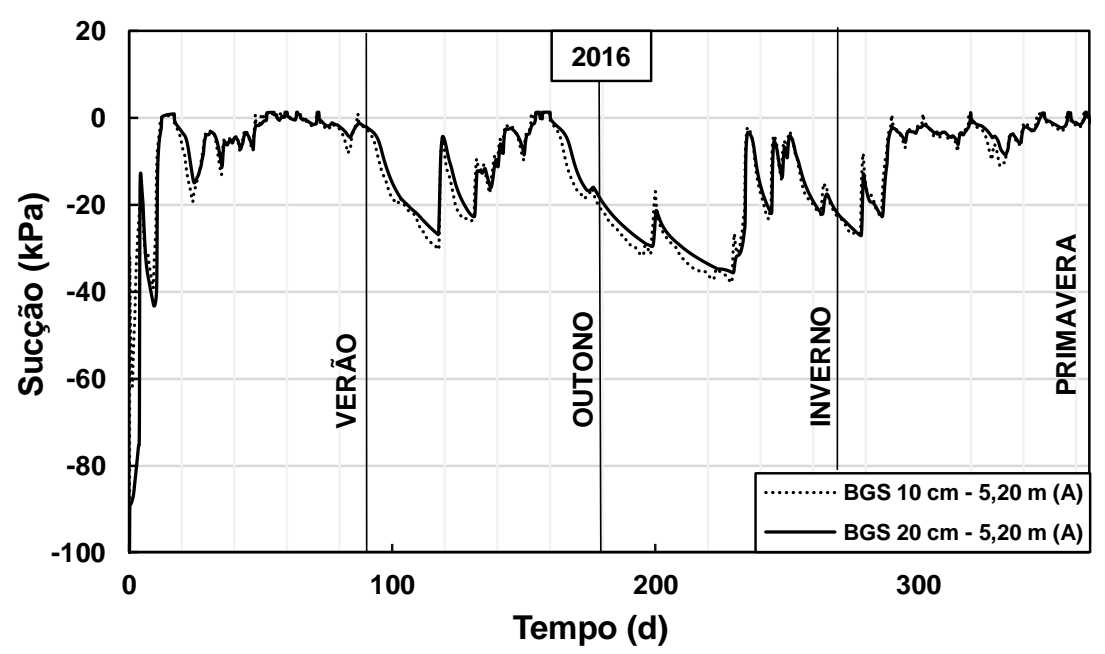

Verificou-se que ao aumentar-se a espessura da BGS de $0,10 \mathrm{~m}$ para $0,20 \mathrm{~m}$, pouco altera os resultados de sucção do subleito no ponto localizado no topo do subleito. Uma pequena variação é notável, somente durante os períodos de intensa evaporação e precipitação. Ou seja, quando o solo se apresenta mais desprotegido, o mesmo tende a ficar mais sensível a eventos de evaporação, alcançando maiores valores de sucção, e infiltração de água, alcançando maiores valores de sucção e tendo picos de saturação em curto intervalo de tempo, respectivamente.

\section{Inclinação}

Por fim, diante de diferentes cenários possíveis analisados para o sublastro granular, decidiu-se verificar também, a influência da inclinação no processo de escoamento superficial, infiltração e precipitação acumulados no ano 2016 (Figura 115, 116 e 117). 
Figura 115 - Escoamento superficial acumulado para diferentes condições de inclinação da via

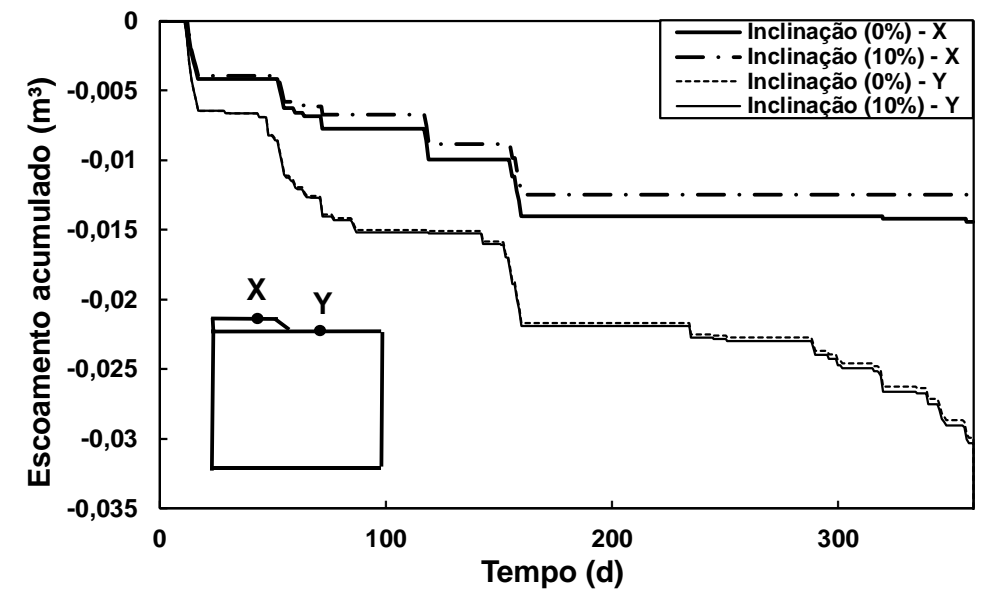

Figura 116 - Infiltração acumulada para diferentes condições de inclinação da via

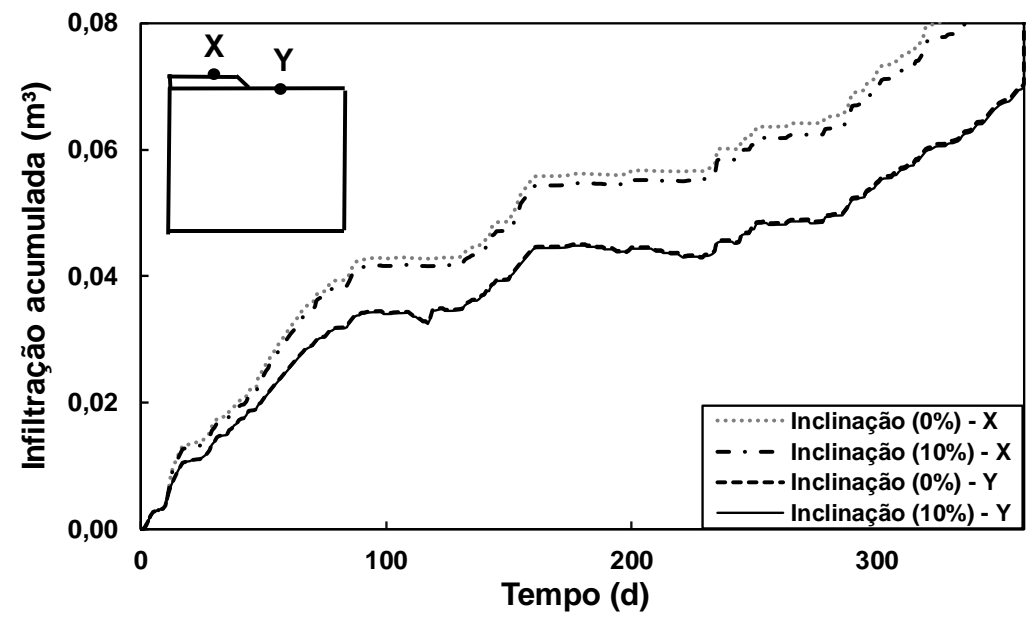

Figura 117 - Chuva acumulada para diferentes condições de inclinação da via

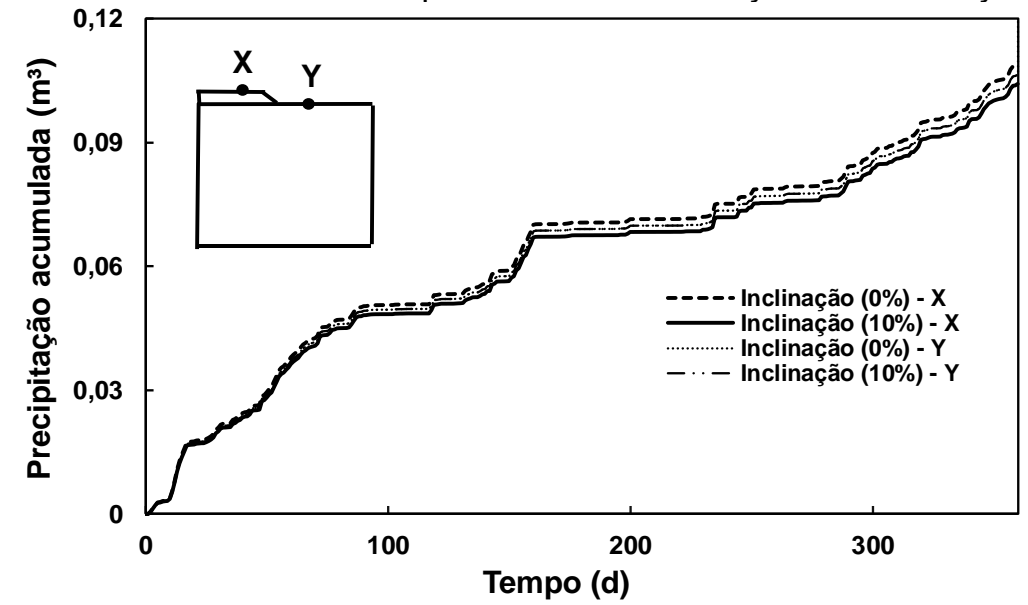

Diante dos resultados obtidos, observou-se que o ponto $X$ possuiu menor valor de escoamento, comparado ao $\mathrm{Y}$, devido à sua posição. Por outro lado, o ponto $\mathrm{X}$ apresentou maiores valores de infiltração, pois o sublastro é mais permeável que o 
subleito. A inclinação da via tende a propiciar um aumento do escoamento superficial, como era esperado, propiciando menores valores de infiltração. De acordo com balanço hídrico, os valores de precipitação foram próximos para as diferentes condições, apresentando uma sensível diferença. Isso ocorre, pois, a quantidade de precipitação na superfície do modelo é função da extensão da superfície do modelo e da inclinação, ou seja, quanto maior a inclinação, maior a área de contato e maiores serão os valores computados para a precipitação. Dessa forma, para que os valores de precipitação se elevem (ponto X), os valores de infiltração devem ser maiores, e consequentemente, o valor de escoamento menor.

Dessa forma, conclui-se que para essas condições geotécnicas e climáticas, a inclinação do sublastro não influenciou na quantidade de água líquida acumulada que infiltra no subleito durante o ano, apesar de melhorar a drenagem da via. Segundo Rushton e Ghataora (2014), o tempo para a água ser drenada de uma camada arenosa sobre um subleito com $5 \%$ de inclinação é duas vezes maior quando comparado com uma condição de $2,5 \%$ de inclinação, demonstrando que a inclinação é importante para o escoamento de água proveniente da chuva.

\subsection{7 - Nível freático versus comportamento hidráulico do subleito}

Objetivando-se verificar a influência da altura do nível freático no comportamento hidráulico do perfil estrutural da via permanente em estudo, simularam-se diferentes cenários com relação a profundidade do lençol freático (Figuras 118, 119 e 120).

Figura 118 - Sucção versus tempo para o ponto A para diferentes níveis freáticos

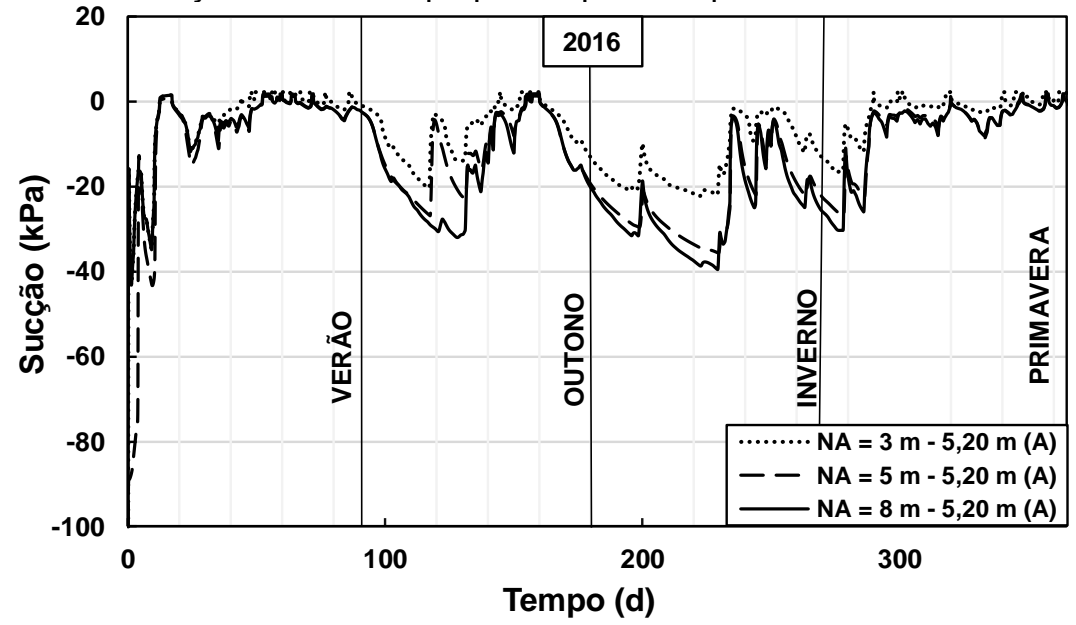


Figura 119 - Sucção versus tempo para o ponto B em diferentes cenários de níveis freáticos

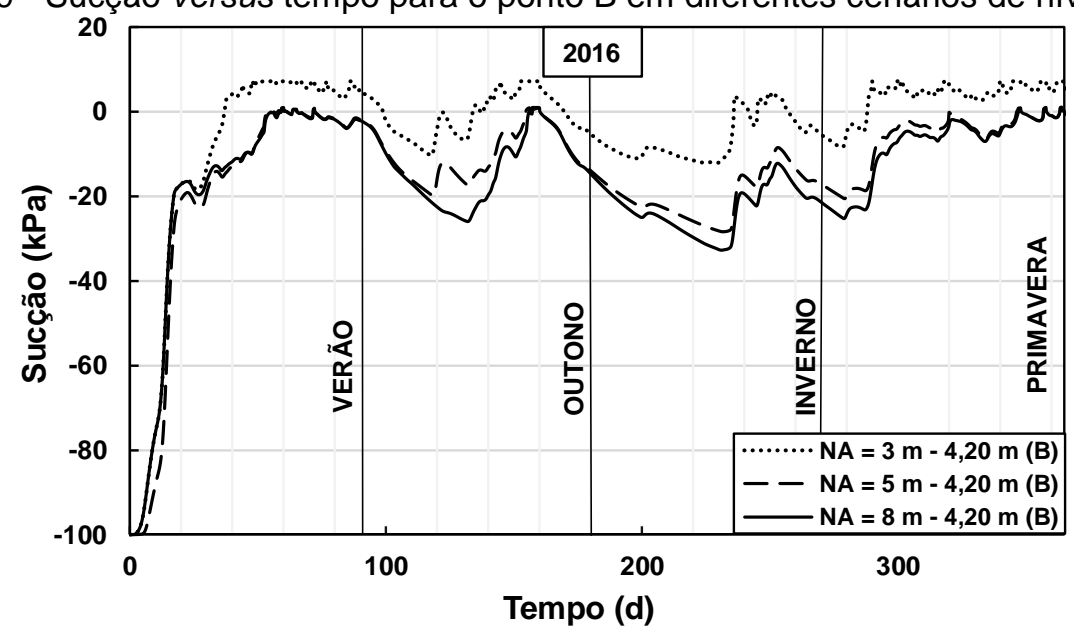

Figura 120 - Sucção versus tempo para o ponto E em diferentes cenários de níveis freáticos

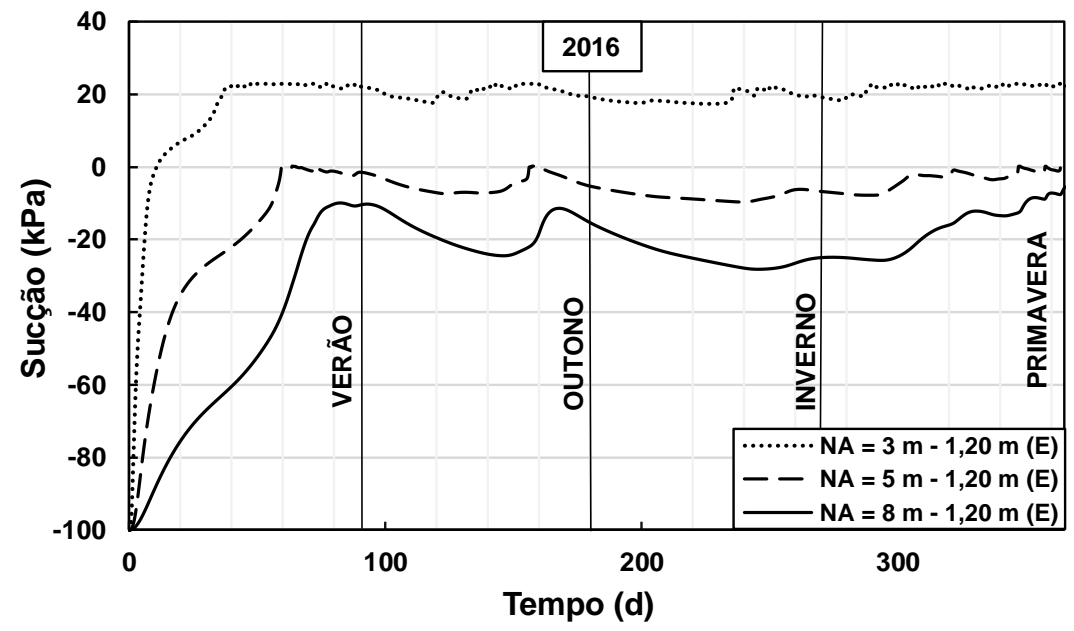

Verificou-se que a posição do nível freático provoca impacto na evolução do grau de saturação do subleito. Como esperado, níveis freáticos mais profundos resultaram em maiores valores de sucção, ou seja, menores valores de umidade iniciais, tendendo a elevar-se com o tempo até atingir o equilíbrio com o clima. Além disso, verifica-se que os pontos localizados no topo do subleito, como o ponto $A$, possuem elevados valores de grau de saturação somente durante o verão (estação úmida), não sofrendo efeitos significativos do nível freático, pois, segundo Ferreira e Teixeira (2012), os seus comportamentos hidrotérmicos são governados diretamente pelas ações climáticas.

Assume-se também que, nas Figuras 119 e 120, os pontos B e E, apresentam poropressões positivas por estarem abaixo do nível freático, sendo considerados 
saturados. Isso prova a importância da consideração de sistemas de drenagens subsuperficiais e profundas adequados, no dimensionamento da via férrea.

\section{3 - Monitoramento de campo}

Foram realizadas campanhas de medição semanais da sucção do subleito da via permanente na Baixada Santista de maio a dezembro (outono à primavera), com o intuito de verificar a variação da sua condição de saturação ao longo das estações do ano em função das condições climáticas. Nas três últimas campanhas, foram coletadas amostras de subleito e de sublastro, a fim de tentar calibrar a curva característica determinada em laboratório (Figura 121).

Figura 121 - Sucção versus tempo de campo em 2018

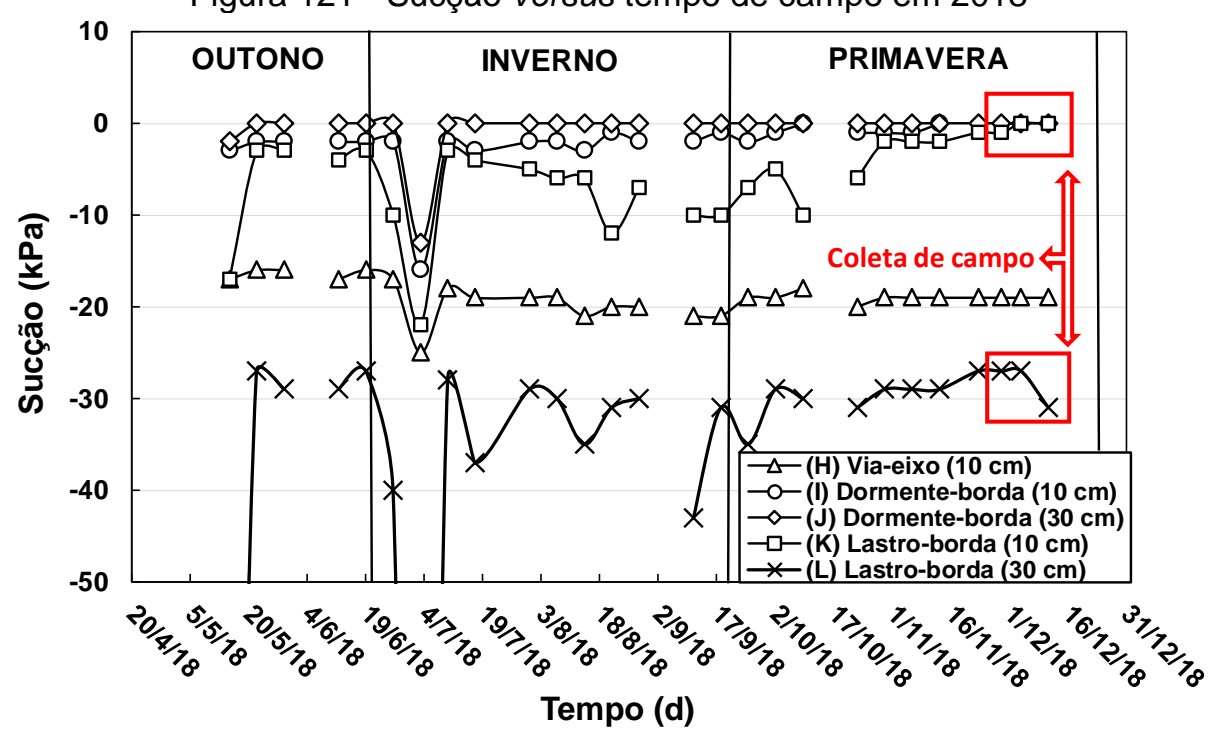

Primeiramente, é importante ressaltar que os dados climáticos utilizados nas simulações através do modelo numérico foram referentes aos anos de 2016 e 2017, diferentemente do campo que foi monitorado durante o ano de 2018, impossibilitando a calibração do modelo. Apesar disso, como o clima possui sempre a mesma tendência para uma mesma região e a curva característica determinada em laboratório é referente ao solo coletado em campo, é válido apresentar e analisar o comportamento hidráulico do subleito sob as duas perspectivas. Desse modo, foi possível observar que o subleito sofreu picos de evaporação durante o inverno 2018, assim como calculado pelo modelo numérico nos anos anteriores. Isso foi contrário 
aos dados obtidos por Cui (2016) no monitoramento do interlayer de uma ferrovia de clima temperado, que verificou constância nos valores de sucção ao longo do ano, evidenciando que o clima tropical influencia intensamente no comportamento hidráulico do subleito ferroviário.

Além disso, verifica-se que os pontos $\mathrm{I}, \mathrm{J}$ e $\mathrm{H}$ localizados abaixo da borda do dormente e do eixo da via, em condição coberta, levou mais tempo para dar início ao processo de secagem que os pontos $L$ e K, localizados nas adjacências da via. Isso era esperado, pois como apresentado pelos resultados do modelo, em períodos de evaporação, a secagem se inicia fora da via onde o sublastro e o subleito estão mais expostos às ações climáticas sendo, logo após, propagada para o eixo da via ou região mais protegida.

Os pontos I e $\mathrm{J}$ apresentaram valores menores de sucção quando comparados com os pontos $\mathrm{L}$ e K, devido ao fato de os mesmos estarem protegidos e assim, possuírem menor tendência de secagem ao longo do tempo em decorrência da camada de lastro, que impede a evaporação nessa região da via. O ponto I, localizado na superfície e abaixo da borda do dormente, apresentou valores maiores de sucção quando comparado ao ponto $\mathrm{J}$, no mesmo local, mas em profundidade, pois pontos superficiais tendem a ser mais sensíveis a eventos de secagem que pontos mais profundos. Além disso, verifica-se que a diferença de sucção entre eles tende a diminuir, assim como os valores aferidos no ponto $\mathrm{K}$, ao se aproximar da primavera, considerada a estação que se inicia o aumento da taxa de precipitação.

Com relação aos pontos $\mathrm{L}$ e $\mathrm{K}$, localizados nas adjacências da via, o primeiro apresentou valores de sucção maiores que o segundo, porém as mesmas intensidades de pico de evaporação, como era esperado. Cui (2016) verificou alguns picos discretos de sucção nas adjacências da via, e conclui que isso ocorre devido a exposição desses pontos as ações climáticas, por estarem desprotegidos. Com a finalidade de entender os menores valores de sucção no ponto $\mathrm{K}$ quando comparado ao ponto $\mathrm{L}$, foi realizado um furo na sua proximidade ( $1 \mathrm{~m}$ de distância longitudinal) em 29/11 para coleta de amostras de solo e comparação dos valores com a sua curva caraterística. Após a escavação, verificou-se que as amostras de solo se 
apresentavam bastante úmidas com umidade variando de 23 a $24 \%$ nos primeiros 30 $\mathrm{cm}$ de profundidade.

Na campanha de medição consecutiva (04/12), decidiu-se escavar o local dos sensores L e K. No decorrer da escavação, verificou-se que o sensor em superfície estava confinado pelo subleito e pelo sublastro, ou seja, com suas extremidades envolvidas pelo solo e pela BGS. Por isso, além do material de solo, foram coletadas amostras do sublastro granular no mesmo local.

Diante dos valores de umidade encontrados para os dois materiais, observou-se que o sublastro apresentava umidade elevada de $13 \%$, considerado saturado, enquanto que o subleito apresentou a mesma umidade daquela encontrada na investigação anterior. Ou seja, tanto os baixos valores de sucção $(0-1 \mathrm{kPa})$ aferidos pelo sensor de superfície nesse dia, quanto nos dias anteriores, devem ter sido influenciados pela condição de saturação da camada de sublastro.

Por fim, foi realizada a última campanha de medição no dia (11/12) e a continuação da coleta de amostras de campo para a verificação dos mesmos valores de 0-1 $\mathrm{kPa}$ obtidos novamente. Constatou-se que os valores de umidade de sublastro continuaram os mesmos, condição saturada, e amostras de subleito nas proximidades variando de $21 \%$ a $24 \%$.

Nessa ocasião, verifica-se que o sensor condiz com a condição de campo, saturada na superfície, e conclui-se que o sublastro granular de BGS, além de possuir a função drenante da água da chuva, ou seja, retenção e escoamento, se torna um obstáculo para a evaporação de água, mantendo úmida a região sob a mesma. A Figura 122 apresenta a calibração dos valores obtidos em campo de umidade e sucção, com a curva de retenção do solo obtida em laboratório. 
Figura 122 - Calibração dos valores obtidos em campo de umidade e sucção com a curva característica determinada através do método 2

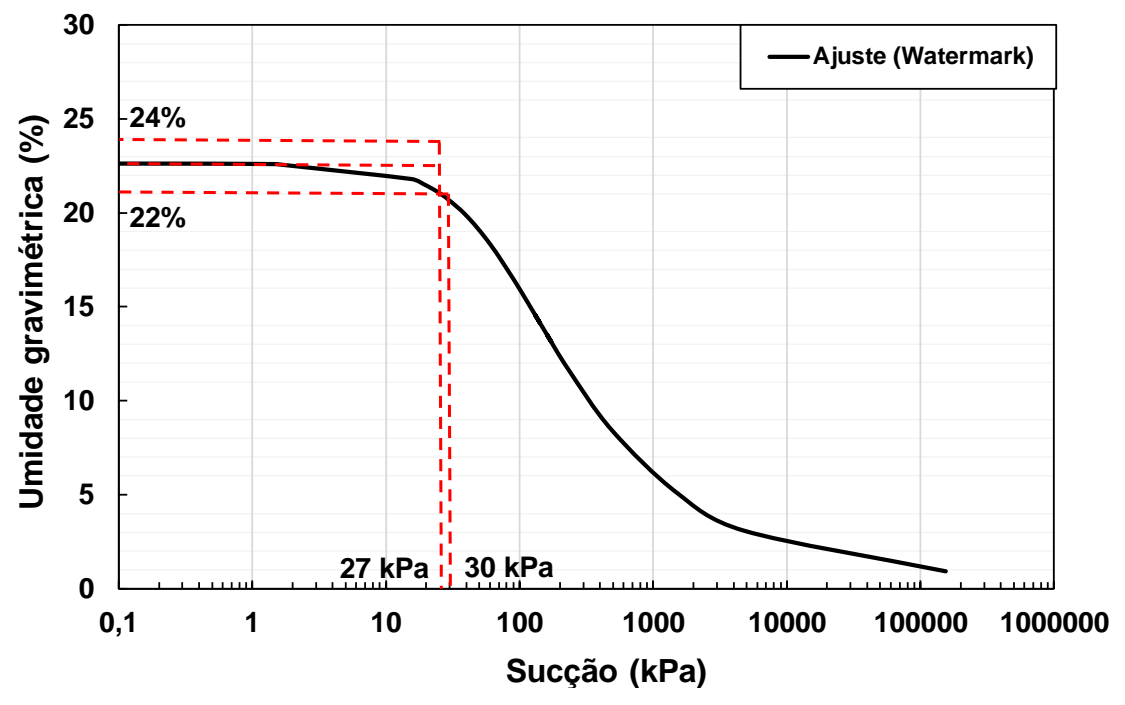

A partir da Figura 122, é possível verificar que, para os últimos três valores de umidade e sucção coletados em campo, foi possível calibrar a curva de retenção do solo obtida em laboratório pelos mesmos tipos de sensores instalados em campo, com um erro de $8 \%$ para a umidade gravimétrica $(2 \mathrm{kPa})$.

Realizaram-se análises da variação dos valores de sucção de uma outra perspectiva, através dos dados obtidos em campo em função da distância transversal, do eixo da via em direção a sua borda ou adjacência, para os sensores em superfície $(H, I$ l $K)$, e em profundidade ( $L$ e J). As Figuras 123, 124, 125 e 126 apresentam esses resultados.

Figura 123 - Sucção versus distância transversal em campo na superfície em 2018

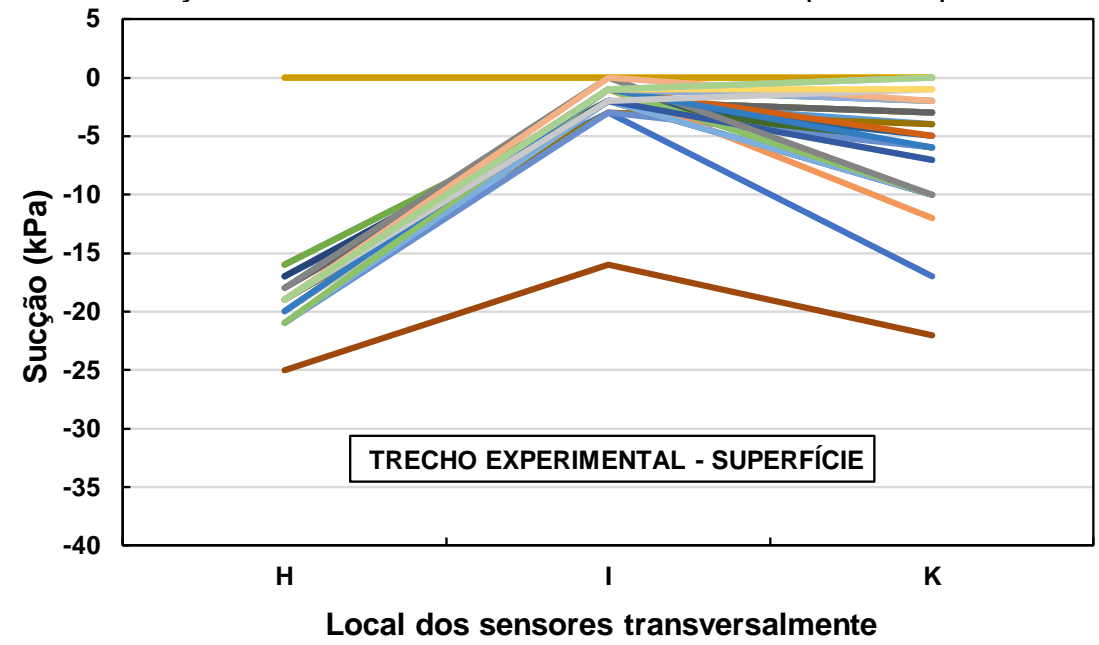


Figura 124 - Análise da tensão de sucção do subleito aferidas em campo na superfície

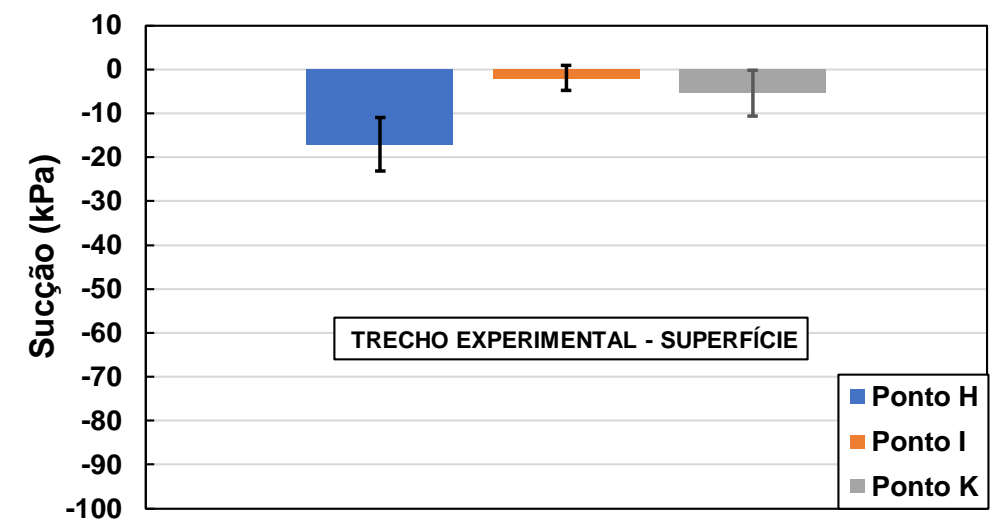

Figura 125 - Sucção versus distância transversal em campo em profundidade no ano de 2018

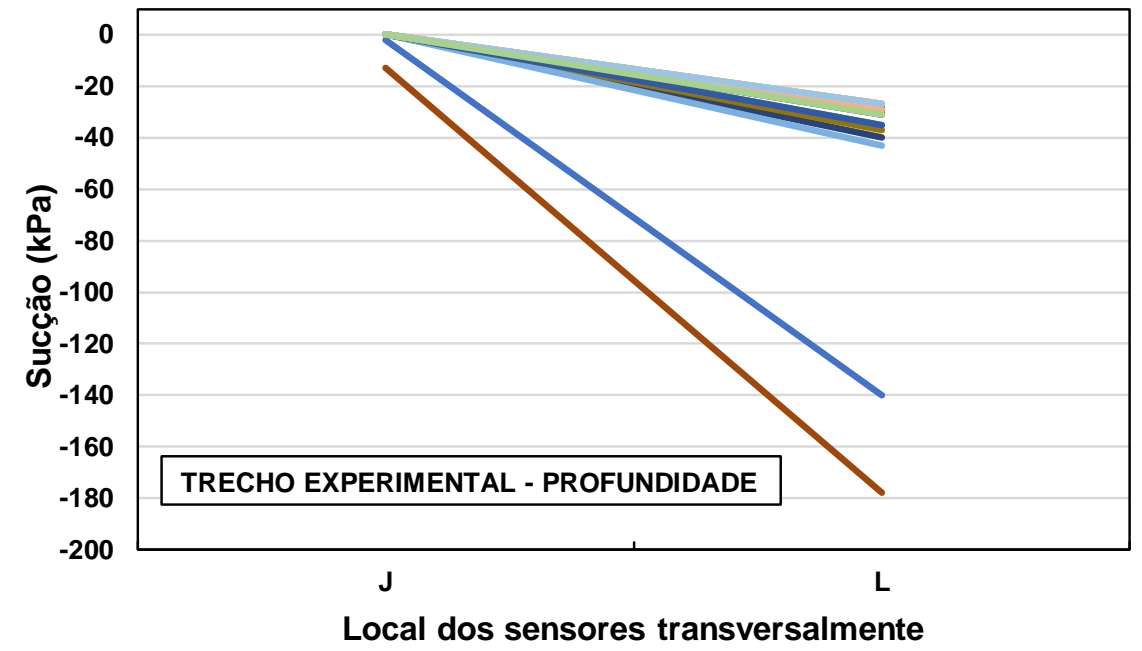

Figura 126 - Análise da tensão de sucção do subleito aferidas em campo em profundidade

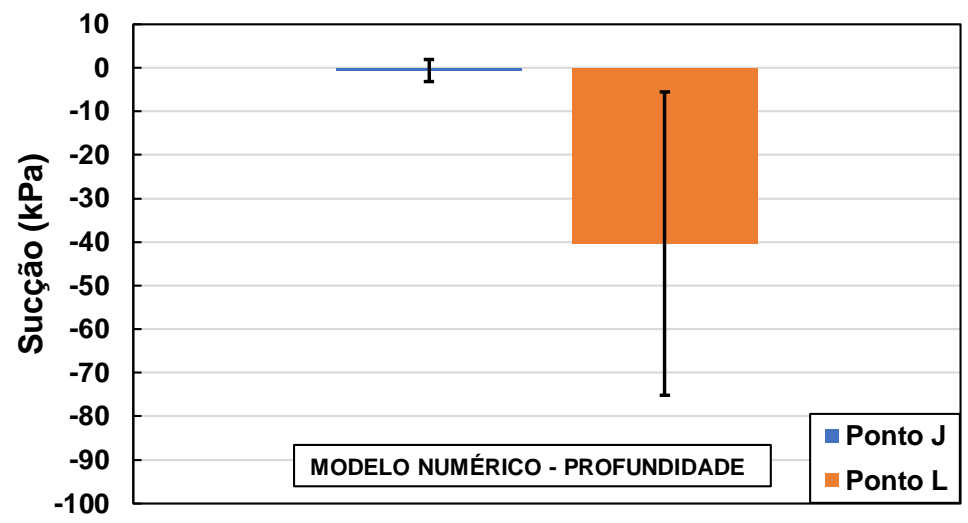

Referente aos sensores de superfície, podem ser observados maiores variações de sucção nos pontos de fora da via quando comparado com o ponto abaixo da mesma, como era esperado. A condição de saturação do sublastro, o qual se encontrou em contato com uma parte do sensor na superfície (ponto $\mathrm{K}$ ), provavelmente influenciou 
os valores de sucção e umidade aferidos e apresentados pelo subleito, impossibilitando a medição de maiores valores de sucção no solo. O ponto I, localizado abaixo da borda do dormente, demonstrou baixos valores de sucção, com pouca variação. Acredita-se que a cota desse ponto é menor do que a cota do ponto localizado sob o eixo da via e na sua adjacência, provavelmente em decorrência das cargas provenientes do tráfego, ocasionando um ponto de acúmulo de água.

Com relação aos dados obtidos pelos sensores em profundidade, verificou-se também um acúmulo de água na região abaixo da borda do dormente, apresentando valores baixos de sucção. Referente ao ponto localizado na adjacência da via, foram observados valores maiores de sucção, compreendendo o intervalo de -20 a $-40 \mathrm{kPa}$, condizente com os valores de umidade das amostras de solo coletadas, em função da curva característica do solo, assim como os valores de sucção obtidos através do modelo numérico.

No geral, os pontos superficiais tiveram uma maior tendência de variação dos valores de sucção quando comparados com os pontos em profundidade, em função do seu maior contato com o clima. Além disso, verificou-se que os pontos superficiais apresentaram menores valores de sucção, pois além de serem sensíveis à eventos de secagem, também são vulneráveis à eventos de umedecimento, os quais influenciam mais em regiões mais expostas ou superficiais. Diante disso, ressalta-se a importância de uma camada de sublastro com densidade e inclinação satisfatórias, para que além de facilitar a evaporação, possa ao mesmo tempo, contribuir para a drenagem da água da chuva e dificultar a infiltração no subleito.

\section{4 - Caracterização mecânica do subleito - Módulo de resiliência}

Pretendendo-se caracterizar mecanicamente o solo do subleito da via permanente estudada nessa pesquisa, foram realizados ensaios de módulo de resiliência em diferentes condições de umidade, e de sucção indiretamente, compactando-se o corpo de prova na umidade desejada e, além disso, submetendo-o à processos de secagem-umedecimento e umedecimento secagem, a fim de simular o efeito do clima no comportamento mecânico do solo. 
A primeira umidade imposta ao corpo de prova foi a ótima (18,0\%), correspondente à um valor de sucção de $100 \mathrm{kPa}$ pela trajetória de secagem (CP1). A norma técnica seguida para a realização do ensaio para essa condição de umidade foi a DNIT 134/2010. A Figura 127 apresenta os resultados da tensão desvio em função da deformação e do deslocamento durante o ensaio.

Figura 127 - Tensão desvio versus deformação para a umidade ótima $(w=18,0 \%)$

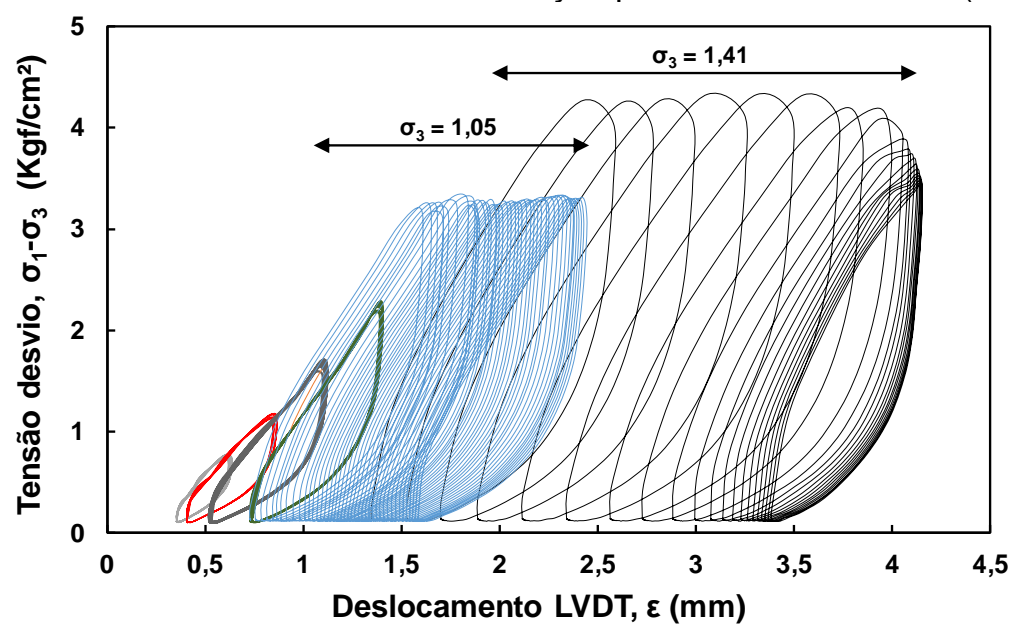

A partir dos resultados, verificou-se que a partir da combinação de tensões com a tensão confinante correspondente à $1,05 \mathrm{Kgf} / \mathrm{cm}^{2}$, o solo não se comportava mais de forma resiliente, apresentando deformações permanentes. Isso, pode mascarar os resultados do ensaio pelo fato de utilizar deformações plásticas e não resilientes no cálculo do módulo de resiliência. Além disso, verifica-se que o solo na sua condição ótima, é altamente deformável, devido a suas características físicas não favoráveis ao seu comportamento mecânico, como explicado no item 4.1.1.

Por isso, os ensaios seguintes, foram realizados conforme a norma DNIT 134/2017, a qual sugere que o ensaio seja realizado até a tensão confinante de 0,07 MPa para solos de subleito, em função da sua baixa capacidade de carga, e a execução de somente um estado de tensão para a fase de condicionamento $\left(\sigma_{3}=0,02\right.$ e $\sigma_{d}=$ $0,02 \mathrm{MPa}$ ). Assim, os resultados de tensão desvio em função do deslocamento para os corpos de prova submetidos aos processos de secagem-umedecimento (CP2) e umedecimento-secagem (CP3), ambos para 15\% de umidade, estão apresentados nas Figuras 128 e 129, respectivamente. 
Figura 128 - Tensão desvio versus deslocamento/deformação para a condição secagem-

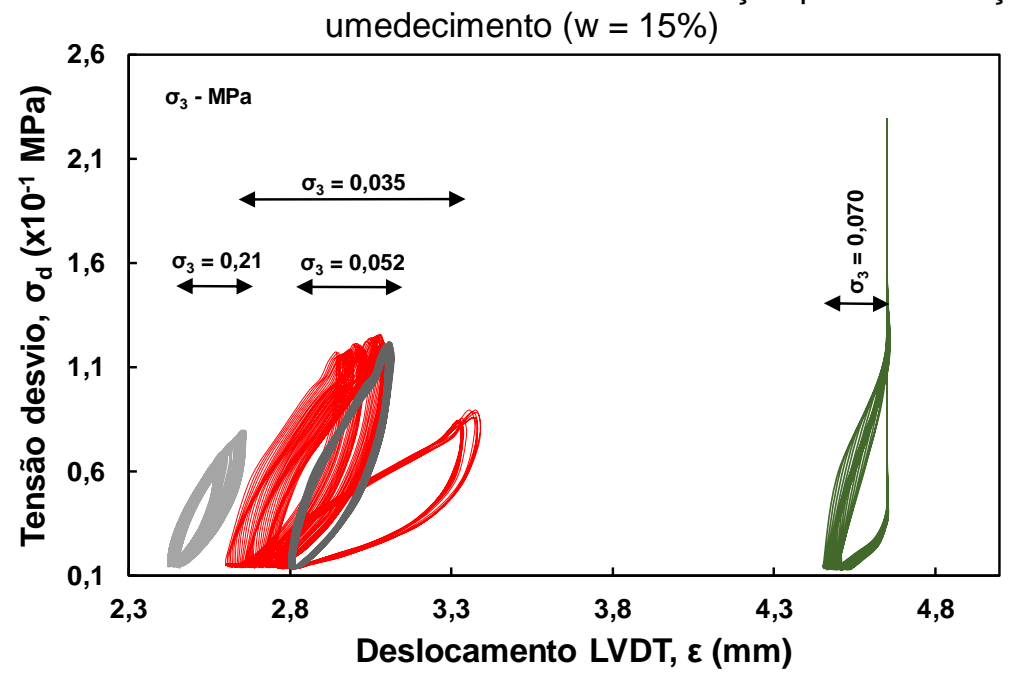

Figura 129 - Tensão desvio versus deslocamento/deformação para a condição de umedecimentosecagem $(w=15 \%)$

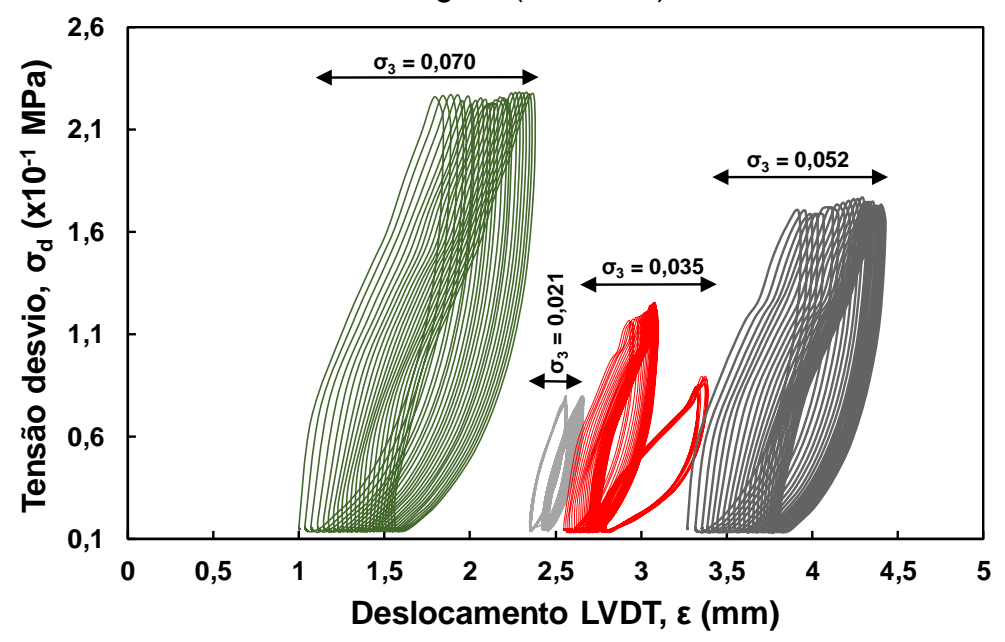

Verificou-se que, após os processos de umedecimento-secagem e secagemumedecimento, resultando em um teor de umidade abaixo da ótima, ou seja, submetido a maiores valores de sucção, o solo se apresentou altamente deformável. Para fins de comparação, os resultados de módulo de resiliência para uma condição de saturação correspondente a 3\% acima da ótima ( $w$ = Wót + 3\%) (CP4) foram obtidos em Alves (2018). As Figuras 130 e 131 apresentam os resultados de módulo de resiliência do CP1, CP2, CP3 e CP4. 
Figura 130 - Módulo de resiliência versus tensão desvio para o CP1, CP2, CP3 e CP4 (escala

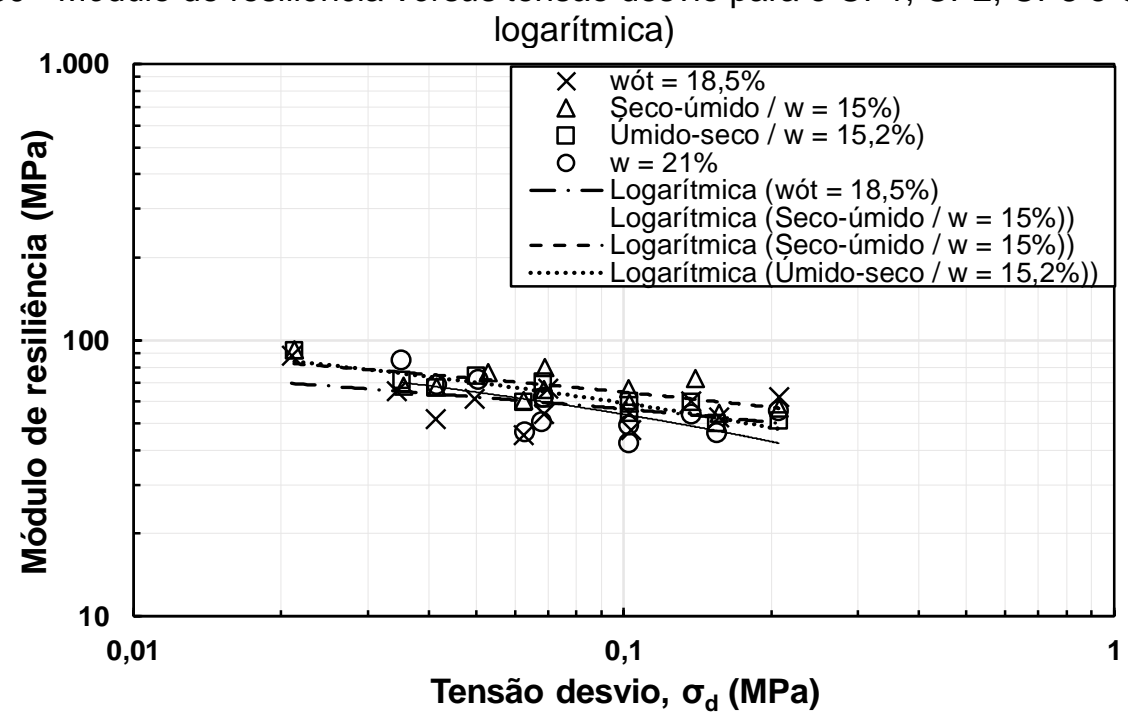

Figura 131 - Módulo de resiliência versus tensão desvio para o CP1, CP2, CP3 e CP4 (escala

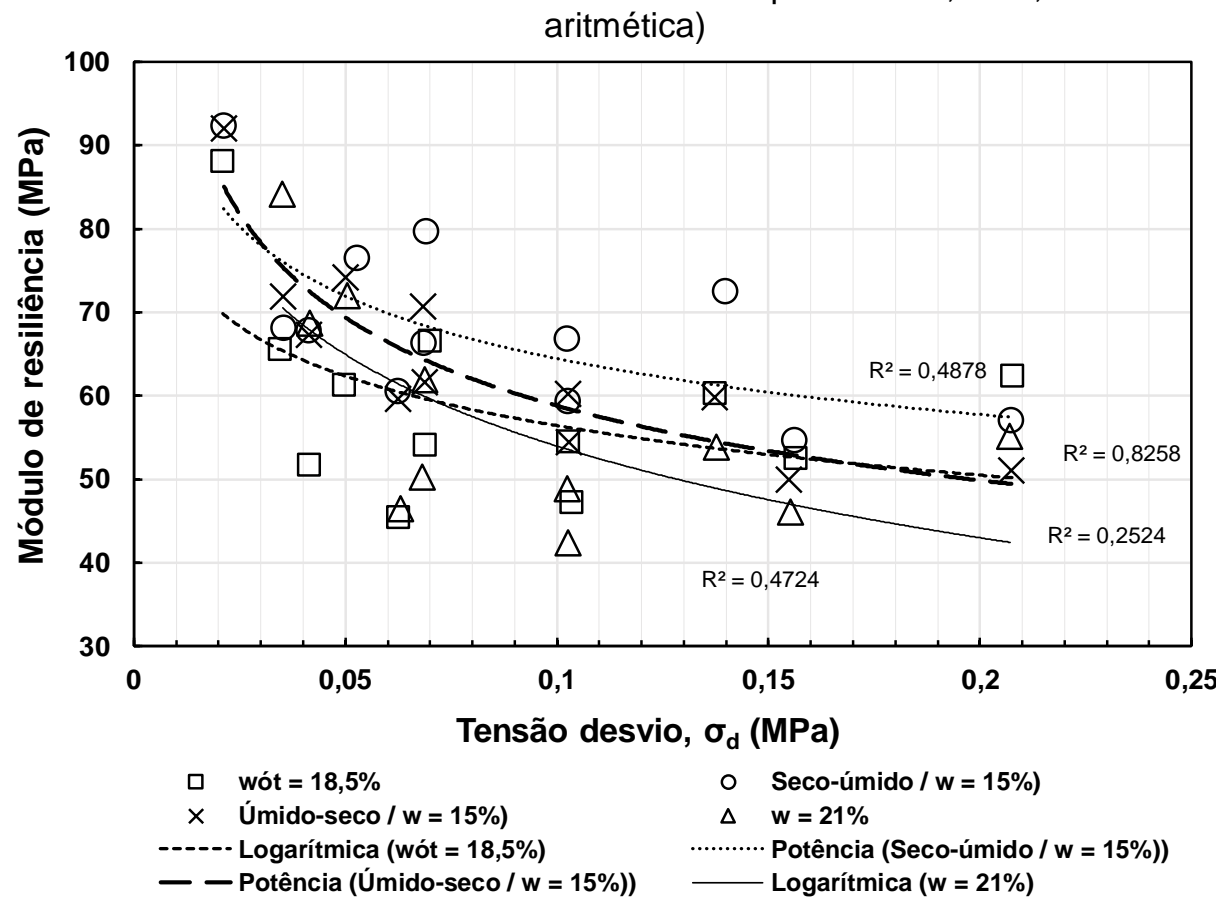

A partir dos resultados expostos nas Figuras 130 e 131, observou-se que esse tipo de solo variando de 15 a 21\% de umidade, correspondente a 100 e 60 kPa de sucção pela trajetória de secagem, apresentou módulo de resiliência de 54 a $65 \mathrm{MPa}$, ou seja, valores baixos e muito próximos, para um valor de tensão desvio de $100 \mathrm{kPa}$.

Ensaios realizados em campo por Selig e Waters (1994), Indraratna et al. (2011) e Anderson e Rose (2008), mostram tensões desviadoras ( $\left.\sigma_{d}\right)$ no subleito variando de 40 a $80 \mathrm{kPa}$, aproximadamente. Considerando-se esse intervalo de tensões para o 
subleito deste trabalho, os resultados de módulo variariam de 61 a $72 \mathrm{MPa}$ para condições de umidade de 15 a 21\%. Ressalta-se que a tensão no topo do subleito não é uma regra, pois varia em função da qualidade do subleito, dos componentes da via, da carga de roda proveniente do material rodante e do clima.

Foi visto, através dos dados de campo e do modelo numérico que o máximo valor de tensão de sucção alcançado pelo solo em função do clima foi de $40 \mathrm{kPa}$, correspondente a umidades gravimétricas acima de $22 \%$, durante a estação seca (inverno). Acima dessa condição de saturação, não foi possível se determinar o módulo de resiliência em função da elevada deformação permanente do corpo de prova durante o ensaio, a qual consumiu o intervalo máximo de medida dos Linear Variable Displacement Transducers (LVDT's) e dos calantes do dispositivo, retratando o seu possível comportamento em campo nessas condições durante a estação úmida (verão).

Por outro lado, segundo Profillidis (2006), caso este solo de subleito permanecesse com esses valores de módulo (61 a $72 \mathrm{MPa}$ ) ao longo do ano, o que não é verídico, o mesmo se enquadraria nos limites do grupo $S_{2}$, de acordo com a classificação da União Internacional de Ferrovias (UIC). Tal grupo é considerado de comportamento médio para subleitos em termos de deformações permanentes, o qual é capaz de suportar as cargas provenientes do tráfego (Figura 132).

Figura 132 - Classificação da qualidade do subleito pela União Internacional de Ferrovias

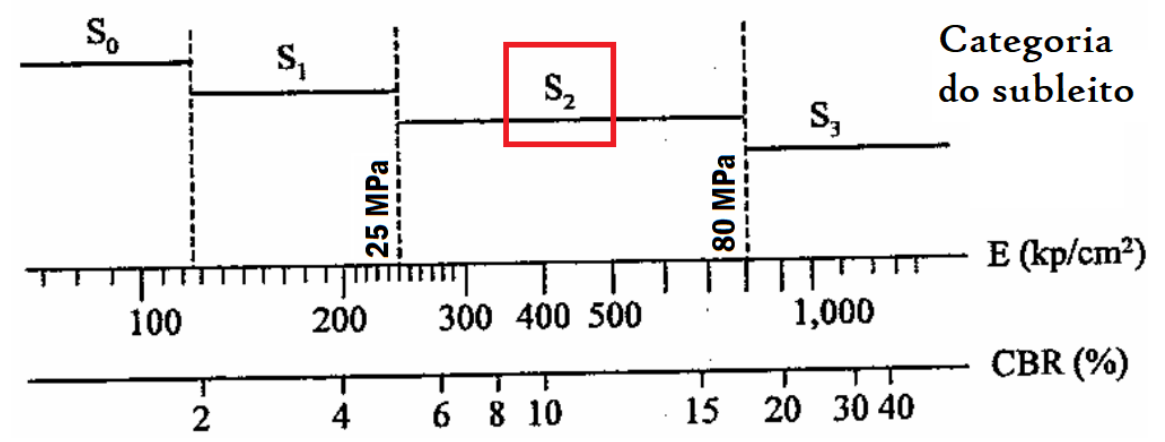

A partir dos resultados para os corpos de prova submetidos a processos de secagemumedecimento e umedecimento-secagem, verificou-se que o segundo apresentou praticamente o mesmo valor (65 MPa) quando comparado ao primeiro (60 $\mathrm{MPa})$, para uma tensão desvio de $100 \mathrm{kPa}$, porém sensivelmente maior, o que não era esperado. 
A curva caraterística do solo obtida pelo método 1, evidenciou que o mesmo ao ser submetido ao processo de umedecimento após ter sido seco, tende a apresentar valores de sucção menores que aqueles submetidos somente a processos de secagem, até a mesma umidade, apresentando um melhor comportamento mecânico.

Rodrigues (1997) solicitou o corpo de prova a ensaios mecânicos de módulo de resiliência, em um ponto na trajetória de secagem após a amostra ter sido compactada, e em outro na trajetória do umedecimento após a mesma ter sido seca, até que ambas possuíssem a mesma umidade, e verificou um aumento da resistência do material nesta última.

No caso deste trabalho, diferentemente de Rodrigues (1997), o corpo de prova referente ao umedecimento-secagem, foi compactado, umedecido e seco e não somente compactado e logo após seco. Tal acontecimento desperta a necessidade de verificar se, a trajetória de secagem após o umedecimento, é a mesma que a trajetória somente de secagem após a compactação para o solo deste trabalho, sem sofrer qualquer tipo de umedecimento.

Em outras palavras, considerar somente a trajetória de secagem, pode não ser suficiente para analisar e compreender o comportamento hidráulico do solo. $\mathrm{Ng}$ e Pang (2000) e Ng et al. (2001) apresentam os ajustes para as curvas características do solo estudado por eles, através de trajetórias de secagem e umedecimento realizadas em duas ou mais vezes consecutivas. Os autores evidenciam e concluem que o solo, no processo de umedecimento, não retorna pela mesma trajetória, atingindo a sua condição saturada com um valor menor daquele que se deu início ao processo de secagem, devido a presença de ar ocluso nos poros.

Dessa forma, o novo ponto de saturação máxima apresenta menores valores de umidade, dando origem a uma nova curva de secagem, abaixo da anterior, ou seja, com menores valores de sucção. Nesse caso, é evidente que os fenômenos climáticos tendem a diminuir o módulo de resiliência do solo, em função dos ciclos de secagem e umedecimento (histerese). A Figura 133 mostra o local dos pontos obtidos pelos dois processos, e verificou-se que, para este solo, os corpos de prova tenderam a 
apresentar o mesmo valor de sucção, para a umidade de $15 \%$, comprovando os mesmos valores de módulo encontrados para os dois casos.

Figura 133 - Valores de sucção obtidos após o ensaio de módulo pelos processos de umedecimento-

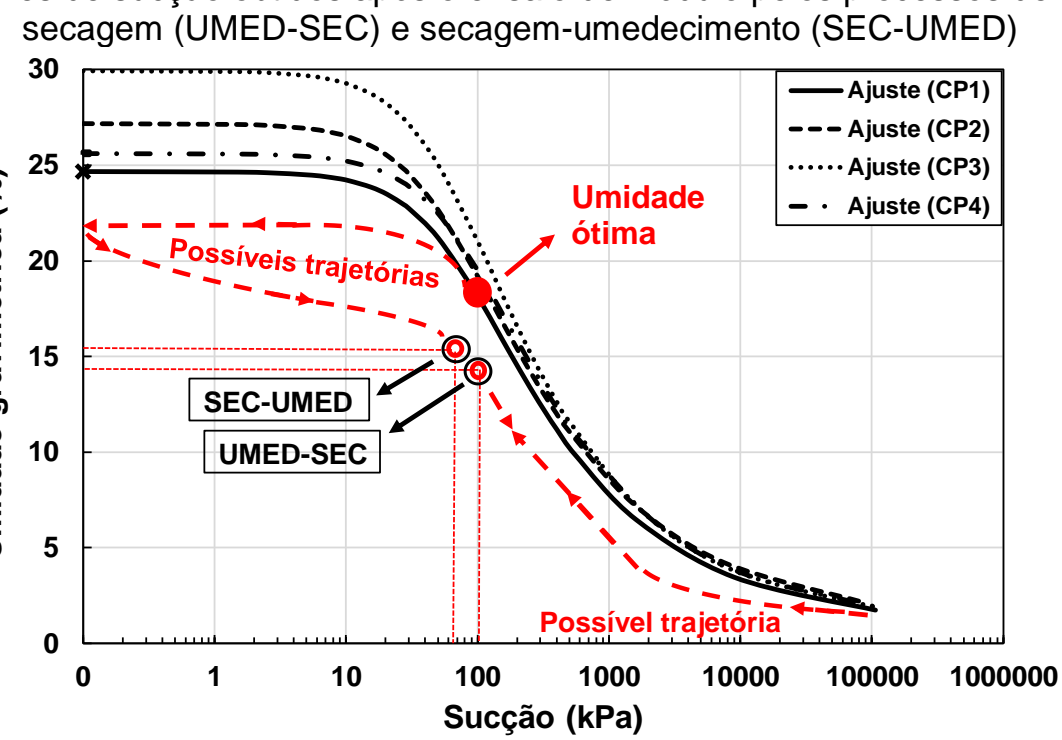

Por fim, verificou-se que os corpos de prova na condição de umidade de $15 \%$, apresentaram maiores valor de módulo quando comparado com a condição ótima e a acima desta, em decorrência do aumento da tensão de sucção à medida que o solo tende a ficar mais seco.

Nesse caso, baseando-se nos dados hidráulicos e mecânicos encontrados até o momento, é evidente que o comportamento mecânico do solo de subleito é diretamente impactado pelas condições climáticas constantemente, apresentando maiores deformabilidades para maiores valores de grau de saturação e menores valores de sucção. Isso pode potencialmente, contribuir para a ocorrência de deformações permanentes e, consequentemente, para a perda de geometria da via, o que é comum no histórico de defeitos do local, de acordo com relatos da equipe de manutenção da ferrovia. Assim, é necessário se considerar o clima e seus efeitos, nos ensaios laboratoriais, no dimensionamento e nos planos de manutenção preditiva do subleito ferroviário. 


\section{5- CONCLUSÕES E COMENTÁRIOS}

Este trabalho se baseou na avaliação do comportamento hidromecânico de um subleito ferroviário, exposto às diferentes condições climáticas do local onde o mesmo foi utilizado, objetivando-se um melhor entendimento sobre a interação via-clima. Com relação ao comportamento hidráulico, foi desenvolvido um modelo numérico de infiltração utilizando-se o software SEEP/W, com o intuito de se simular um trecho experimental de uma via permanente, o qual foi devidamente instrumentado com sensores no subleito para o monitoramento dos dados de sucção. Para a caracterização mecânica, foram realizados ensaios de módulo de resiliência com o material de campo em diferentes condições de saturação, simulando situações reais de campo.

Com relação ao modelo numérico, observou-se que a infiltração de água proveniente de eventos chuvosos, atuante diretamente no subleito em condição não saturada, depende da taxa de precipitação do local onde a via foi construída, do coeficiente de permeabilidade, da função de condutividade hidráulica e da curva característica. A frente de umidade, ocorrente no perfil da via em decorrência da infiltração de água, tende a manter, nas proximidades do topo de subleito, com maiores valores de grau de saturação, o qual decresce em função da profundidade. Além disso, o perfil de umidade tende a entrar em equilíbrio com o clima ao longo das estações do ano. A média de umidade do subleito tende a variar em maior quantidade, nas adjacências da via ou zona desprotegida, onde está mais exposta às ações climáticas. Os resultados enfatizaram a importância não somente da precipitação, mas também do fenômeno de evaporação, mesmo possuindo baixos valores ao longo do ano. Por fim, o nível freático demonstrou importância quanto aos valores de sucção e umidade do subleito ferroviário, podendo provocar problemas estruturais, caso não existam sistemas de drenagem superficial, subsuperficial e profundo adequados.

O inverno (estação seca) foi analisado, considerando-se a influência de eventos chuvosos, mesmo não sendo predominantes nesse período. Concluiu-se que após um intenso período de secagem, o qual elevou a sucção do solo ao seu maior nível ao longo do ano, chuvas repentinas (intensas e/ou duradouras) podem ocorrer e 
alterar bruscamente a condição de saturação do subleito, principalmente quando o solo utilizado é muito sensível às variações climáticas, como o desta pesquisa. Além disso, verificou-se que os pontos localizados abaixo da via, tendem a se manter com valores elevados de sucção, quando comparados aos pontos mais expostos (fora da via), mostrando a importância do sublastro como camada protetora. Apesar disso, o sublastro granular não demonstrou ser eficiente a longo prazo, permitindo um elevado índice de infiltração de água no subleito em eventos de chuva, quando o mesmo atinge a sua saturação. Por fim, observou-se que uma camada protetora sobre o subleito também torna-se prejudicial ao mesmo, pois ao impedir a água retida de evaporar-se durante os períodos de estiagem, também mantêm elevado o seu grau de saturação e baixo o valor de sucção, podendo provocar deformações permanentes, perda de geometria e, consequentemente, aumentar os custos com manutenções.

O verão (estação úmida) também foi abordado, a fim de se analisar o comportamento hidráulico da via no período de chuvas mais intensas. Observou-se que, após a condição inicial do subleito (umidade ótima), o seu grau de saturação começa a se elevar até alcançar elevados níveis de saturação (baixos valores de sucção). Assim como durante o inverno, tal redução é mais perceptível nos pontos do subleito localizados nas adjacências da via, em decorrência da ausência das camadas de proteção. Ressalta-se que, apesar da existência de um sublastro granular, o solo de subleito sob a via alcança níveis de umidade bastante elevados. Cardoso et al. (2012) relata que tal incremento de umidade é responsável pelo acúmulo de deformação permanente ao longo do ano. Desse modo, sugere-se uma camada menos porosa e mais extensa (transversalmente), a fim de que, o solo aplicado seja resiliente aos eventos climáticos. Por fim, é importante destacar-se que a umidade ótima do solo de subleito compactado durante o verão é reduzida bruscamente em um curto espaço tempo, diferentemente do inverno, o qual mantém umidades próximas à sua condição ótima por mais tempo.

O modelo desenvolvido demonstrou ser uma ferramenta confiável para se simular infiltração não saturada em um perfil de via permanente ferroviária em função das características geotécnicas e climáticas. Foi possível, analisarem-se os perfis de sucção e umidade na estrutura da via férrea, assim como o balanço hídrico na sua 
superfície, em cada estação do ano, com base em dados climáticos locais, podendo ser importante a sua consideração, no processo de seleção de materiais e na previsão de seu comportamento hidráulico, antes da sua aplicação em campo.

Referente ao monitoramento de campo, verificou-se que os pontos localizados nas adjacências da via, apresentaram maiores variações de sucção, assim como evidenciou o modelo numérico, devido a maior exposição ao clima. Picos de sucção foram observados no inverno, assim como apresentado pelo modelo, mostrando o possível efeito positivo do período de estiagem, no comportamento hidromecânico do subleito. Além disso, observou-se que é imprescindível uma inclinação e execução adequadas do subleito da via (terraplenagem), dificultando possíveis acúmulos de água sob o mesmo e facilitando a sua drenagem. O sublastro granular apresentou-se saturado nas três últimas medições, enquanto que o subleito, se mostrou não saturado no mesmo ponto de análise. Isso mostra o potencial de retenção e drenagem da camada de sublastro, caso a mesma possua inclinação e execução adequadas. A partir do material de subleito coletado para caracterização física e hidráulica em laboratório, foi possível calibrarem-se as três últimas leituras de sucção de campo com a curva característica do solo de laboratório, obtida através do mesmo tipo de sensor utilizado em ambos.

Diante dos dados de sucção e umidade obtidos através do modelo numérico e do monitoramento de campo, foram realizados ensaios de caracterização mecânica do material de subleito estudado. Os ensaios de módulo de resiliência mostraram que, é determinante analisarem-se as possíveis condições de saturação (secagem e umedecimento) de campo provocadas pelo clima, antes de se analisar o solo em laboratório e de selecioná-lo no processo de dimensionamento e/ou planejamento de manutenções, com base na sua umidade ótima. Analisar o material sempre em sua condição ótima, mascara a verdadeira condição na qual o material pode ser submetido. Desse modo, verificou-se que o material de solo utilizado como subleito nessa via, possui elevada deformabilidade (baixos valores de sucção) nas suas condições reais de campo, pois o seu tipo e o clima local, não permitem que o mesmo, saia de uma condição de elevado grau de saturação (comportamento mecânico precário), para condições mais secas (comportamento mecânico tolerável). 


\section{6 - SUGESTÕES PARA PESQUISAS FUTURAS}

- Analisar a influência do clima no comportamento hidráulico do subleito, considerando-se a curva de caraterística do solo com histerese (secagemumedecimento), o fluxo de vapor e térmico;

- Simular, através de elementos finitos, a infiltração na via permanente com diferentes condições de colmatação do lastro, a fim de verificar a influência de tal camada nos perfis de sucção do subleito;

- Modelar, em elementos finitos, a deformabilidade do subleito ao longo do tempo em função das variáveis climáticas em clima tropical, considerando-se solos lateríticos e não lateríticos;

- Instrumentar a via permanente com estações meteorológicas, para o monitoramento real do clima, com sensores de sucção e umidade, a fim de se obter a calibração de campo e com células de pressão, settlement pegs, e dispositivos para a medição do deslocamento, a fim de buscar-se o entendimento em condições reais, sobre a verdadeira influência da variação do comportamento hidráulico do subleito, no comportamento mecânico global da via permanente;

- Desenvolver um dispositivo de medição de módulo de resiliência em laboratório, com variação do estado de tensão do corpo de prova, com o intuito de se simularem diversas condições de saturação de campo em laboratório;

- Desenvolver modelos analíticos de módulo de resiliência em função da curva característica do solo, com o intuito de se estimar o módulo através desta, para se utilizar como metodologia de seleção de materiais para subleito;

- Desenvolver modelos analíticos de deformação permanente com base na análise não saturada do subleito, com o intuito de prever a sua deformabilidade com o tempo e como isso pode provocar a evolução da geometria da via.

- Analisar, através dos princípios da mecânica dos solos não saturados, diferentes tipos de sublastro como proteção do subleito quanto à umidade e redução de deformação permanente. 


\section{REFERÊNCIAS BIBLIOGRÁFICAS}

ABNT NBR NM 248/2003 Agregados - Determinação da composição granulométrica. Associação Brasileira de Normas Técnicas, Rio de Janeiro. 2003.

ABNT NBR 13292/1995 - Determinação do coeficiente de permeabilidade de solos granulares à carga constante. 1995 .

ABNT NBR 6457. Amostras de solo - Preparação para ensaios de compactação e ensaios de caracterização. Associação Brasileira de Normas Técnicas. Rio de Janeiro. 2016.

ABNT NBR 6459. Solo - Determinação do limite de liquidez. Associação Brasileira de Normas Técnicas. Rio de Janeiro. 2016.

ABNT NBR 7180. Solo - Determinação do limite de plasticidade. Associação Brasileira de Normas Técnicas. Rio de Janeiro. 2016.

ABNT NBR 7181. Solo - Análise granulométrica. Associação Brasileira de Normas Técnicas. Rio de Janeiro. 2016.

ABNT NBR 7182. Solo - Ensaio de compactação. Associação Brasileira de Normas Técnicas. Rio de Janeiro. 2016.

ANTT. Anuário do setor ferroviário. Agência Nacional de Transportes Terrestres. 2017.

ALMEIDA, J. R. Estudo do comportamento de barreira capilar em aterros de resíduos. Dissertação de mestrado. Universidade Federal do Rio de Janeiro. 2011.

ALVES, T. F. Análise do comportamento de via permanente lastrada com emprego de sublastro betuminoso. Dissertação de mestrado. Universidade de São Paulo. São Paulo. 2018.

ANDERSON, J. S.; ROSE, J. G. In-situ test measurement techniques within railway track structures. IEEE/ASME/ASCE 2008 Joint Rail Conference. Delaware: USA. 2008.

AREMA. American Railway Engineering and Maintenance of Way Association. Manual for Railway Engineering. Vol. 1 a 4. 2013.

ASTM D2487-17, Standard practice for classification of soils for engineering purposes (Unified Soil Classification System), American Society of Testing Materials, 2017.

ASTM D2488-17e1, Standard practice for description and identification of soils (Visual-Manual Procedures), American Society of Testing Materials, 2017. 
ASTM D5084-16a, Measurement of hydraulic conductivity of saturated porous materials using a flexible wall permeameter, American Society of Testing Materials, 2016.

ASTM D5298-16, Standard test method for measurement of soil potential (suction) using filter paper. American Society of Testing Materials, 2016.

AUBERTIN, M; MBONIMPA; BUSSIĖRE, B.; CHAPUIS, R. P. A model to predict the water retention curve from basic geotechnical properties, Canadian Geotechnical Journal, 40 (6): 1104 - 1122, 2003.

AZEVEDO NETTO, J. M. Manual de hidráulica. Ed. Edgard Blutcher, São Paulo, 669p. 1998.

BALBO, J. T. Pavimentação asfáltica: materiais, projetos e restauração. São Paulo: Oficina de Textos, 2007.

BERNUCCI, L. Considerações sobre o dimensionamento de pavimentos utilizando solos lateríticos para rodovias de baixo volume de tráfego. Tese de doutorado. Universidade de São Paulo. São Paulo. 1995.

BLIGHT, G. E. Aspects of the capillary model for unsaturated soils. Proc. 7th. Asian Conference. SMFE.. Haifa. 1983.

BROOKS, R. H.; COREY, A. T. Hydraulic properties of porous media. Colorado State University, Fort Collins. Hydrology Paper, v.3, p.27. 1964.

CAMACHO, J. Peculiaridades de distribuição de umidades em bases de pavimento de solo arenoso fino laterítico. Tese de doutorado, Universidade de São Paulo. São Paulo, 180 p. 2002.

CARDOSO, C. Estudo do comportamento de um solo residual de gnaisse não saturado para avaliar a influência da infiltração na estabilidade de taludes. Dissertação de mestrado. Universidade de São Paulo. São Paulo. 2006.

CARDOSO, R.; FERNANDES, V.; FERREIRA, T.; TEIXEIRA, P. F. Settlement prediction of high speed highway embankments considering the accumulation of wetting and drying cycles. Unsaturated Soils: research and applications. 2012.

CHARD, J. Watermark soil moisture sensors: characteristics and operating instructions. 2004.

CHOW, V. T. Open channel hydraulics. McGraw-Hill Book Company, New York, 1959, Reissued. 1988.

CONFEDERAÇÃO NACIONAL DE TRANSPORTES. Pesquisa CNT de ferrovias. Brasília. CNT. 2015.

CORDEIRO, W. R.; GUIMARÃES, A. C. R.; MARQUES, M. E.. Manutenção preditiva de infraestrutura ferroviária em um trecho da malha de SP. n. 1, p. 1-18, 2015. 
COSTA, R. C. Proposição de dispositivo de medidas "in situ" para avaliação do comportamento mecânico de lastro ferroviário: Estudo de caso na Estrada de Ferro Carajás. Dissertação de mestrado, Universidade de São Paulo. São Paulo, 176 p. 2016.

CUI, Y. J. Unsaturated railway track-bed materials. E3S Web of Conferences, v. 9, p. 1001, 2016.

DERSA ET-DE-P00/008. Sub-base ou base de brita graduada. Desenvolvimento Rodoviário S.A. São Paulo. 2005.

DNER. DNER-CLA 259/96. Classificação de solos tropicais para finalidades rodoviárias utilizando corpos-de-prova compactados em equipamento miniatura. Departamento Nacional de Estradas e Rodagens. [S.I.], p. 01-06. 1996.

DNER-ME 093/94. Solos compactados em equipamento miniatura Determinação da perda de massa por imersão. Departamento Nacional de Estradas e Rodagens. p. 01-06. 1994.

DNER-ME 228/94. Compactação em equipamento miniatura. Departamento Nacional de Estradas e Rodagens. p. 01-14. 1994.

DNER-ME 256/94. Solos - Determinação da densidade real. Departamento Nacional de Estradas e Rodagens. p. 01-04. 1994.

DNER-ME 258/94. Solos compactados em equipamento miniatura - Mini- MCV. Departamento Nacional de Estradas e Rodagens. p. 01-16. 1994.

DNIT 134/2010 - ME Pavimentação - Solos - Determinação do módulo de resiliência - Método de ensaio. Rio de Janeiro. 2010.

DNIT 134/2017 - ME Pavimentação - Solos - Determinação do módulo de resiliência - Método de ensaio. Rio de Janeiro. 2017.

DOYLE, N. F. Railway track design a review of current practice. Bureau of Transport Economics. BHP Melbourne Research Laboratories. 1980.

EDIL, T. B.; MOTAN, S. E. Soil-water potencial and resilient behavior of subgrade soils. Transportation Research Record, n. 705, p. 54-63, 1979.

ESVELD, C. Modern Railway Track. 2nd. ed. [S.I.]: Delft University of Technology. 2001.

FERREIRA, T. M.; TEIXEIRA, P. F. Rail track performance with different subballast solutions: traffic and environmental effects on subgrade service life. Journal of Transportation Engineering, v. 138, n. 12, p. 1541-1550, 2012.

FERREIRA, T. M.; TEIXEIRA, P. F.; CARDOSO, R. Impact of bituminous subballast on railroad track deformation considering atmosferic actions. Journal of 
Geotechnical and Geoenvironmental Engineering. 2011.

FORTUNATO, E. M. C. Renovação de plataformas ferroviárias: estudos relativos à capacidade de carga. Ph.D Thesis. 2005.

FREDLUND, D. G. The emergence of unsaturated soil mechanics. The fourth Spencer J. Buchanan Lecture, College Station, Texas, A\&M University Press, 39 pp. 1996.

FREDLUND, D. G.; BERGAN, A. T.; SAUER, E. K. Deformation characteristcs of subgrade soils for highways and runways in Northern enviorments. Canadian Geotechnical Journal, v.12, n.2, p. 213-223, 1975.

FREDLUND, D. G.; MORGENSTERN, N. R. Stress state variables for unsaturated soils. Journal of Geotechnical Engineering Division. v. 103. p. 447-466. 1977.

FREDLUND, D. G.; MORGENSTERN, N. R.; WIDGER, R. A. The shear strength oh unsaturated soil. Canadian Geotechinical Journal, Vol. 15, n. 3, pp. 313-321, 1978.

FREDLUND, D. G.; RAHARDJO, H. Soil mechanics for unsaturated soils. John Wiley and Sons, Inc., 1993.

FREDLUND, D. G.; RAHARDJO, H.; FREDLUND, M. G. Unsaturated soil mechanics in engineering practice. 2012.

FREDLUND, D. G.; XING, A. Equations for the soil-water characteristic curve. University of Saskatchwan. Canadian Geotechnical Journal, 31(3): 521-532. Canada. 1994.

FREDLUND, D.G; XING, A.; HUANG, S. Predicting the permeability function for unsaturated soils using the soil-water characterstic curve. Canadian Geotechnical Journal. 31(3). 521-532. 1994.

GANJEGUNTE, G. K.; SHENG, Z.; CLARK, J. Evaluation the accuracy of soil water sensors for irrigation scheduling to conserve freshwater. Applied Water Science. v.2. 119-125. 2012.

GEOSLOPE International. Seepage modeling with SEEP/W Manual. An Engineering Methodology. 2012b.

GEOSLOPE International. Seepage modeling with VADOSE/W Manual. An Engineering Methodology. 2012a.

GERSCOVICH, D. M. S. Equações para modelagem da curva característica aplicadas a solos brasileiros. IV Simpósio Brasileiro de Solos Não-Saturados. Porto Alegre. pp. 76-92. 2001.

GERSCOVICH, D. M. S.; SAYÃO, A. F. S. J. Evaluation of the soil-water characteristic curve equations for soils from Brazil. The International Conference on Unsaturated Soils. Recife. pp. 295-300. 2002. 
GHATAORA, G. S., RUSHTON, K. Movement of water through ballast and subballast for dual-Line railway track. Transportation Research Record(2289), 7886, 2012.

GHATAORA, G. S.; BURNS, B.; BURROW, M.; EVDORIDES, H. Development of an index test for assessing anti-pumping materials in railway track foundations. First International Conference on Railway Foundations, University of Birmingham, Birmingham, UK, pp. 355-366. 2006.

GLENDINNING, S., HALL, J., e MANNING, L. Asset-management strategies for infrastructure embankments. Proceedings of the ICE - Engineering Sustainability, 162, 111-120, 2009.

HAN, Z.; MIHAMBANOU, B.; VANAPALLI, S. K. A new approach for estimating the influence of soil suction on the resilient modulus of pavement subgrade soils. Airfield and Highway Pavements 2015: Innovative and Cost-Effective Pavements for a Sustainable Future - Proceedings of the 2015 International Airfield and Highway Pavements Conference, v. 4, p. 593-604, 2015.

HAN, Z.; VANAPALLI, S. K. Relationship between resilient modulus and suction for compacted subgrade soils. Engineering Geology, v. 211, p. 85-97, 2016.

HASNAYN, M. M.; MCCARTER, W. J.; WOODWARD, P. K.; CONNOLY, D. P. STARRS, G. Railway subgrade perfomance during flooding and the postflooding (recovery) period. Transportation Geotecchnics. 2017.

HAY, W. W. Railroad Engineering, 1982.

INDRARATNA, B.; SALIM, W.; RUJIKIATKAMJORN, C. Advanced rail geotechnology - ballasted track. CRC Press. Taylor \& Francis Group, London, UK. 2011.

INMET. INSTITUTO NACIONAL DE METEREOLOGIA. Normais climatológicas de 1961 a 1990 e 1981 a 2010. 2018.

INTERGOVERNMENTAL PANEL ON CLIMATE CHANGE. Climate change 2013: The physical science basis. IPCC. 2013.

KOVACS, G. Seepage hydraulics. Developments in Water Science 10. Elsevier Scientific Publishing Co. Amsterdam. Oxford. New York. 1981.

LAMBE, T. W.; WHITMAN, R. V. Soil Mechanics. Massachussets Institute of Technology. New York: John Wiley e Sons. 1969.

LEE, H. C., WRAY, W. K. Techniques to evaluate soil suction - avital unsaturated soil water variable, Unsaturated Soils, v. 2, pp. 615-622. 1995.

LI, B. D. Railway track granular layer thickness design based on subgrade performance under repeated loading. Tese de doutorado. University of Massachusetts Amherst, 321, 1994. 
LI, B. D.; MEMBER, A.; SELIG, E. T. Resilient modulus for fine-grained subgrade soils. v. 120, n. 6, p. 939-957, 1994.

LI, D.; SELIG, E. T. Evaluation of railway subgrade problems. Transportation Research Record, n. 1489, p. 17-25, 1995.

LI, D.; SELIG, E. T. Method for railroad track foundation design I: development. Journal of Geotechnical and Geoenvironmental Engineering, 124(4), 316-322. 1998.

LOPES, L. S. Análise experimental do comportamento hidráulico e mecânico do pavimento ferroviário. Dissertação de mestrado. Universidade Federal do Rio de Janeiro. Rio de Janeiro. 2017.

LOPES, R. L. Infiltração de água e emissão de metano em camadas de cobertura de aterros de resíduos sólidos. Tese de doutorado. Universidade Federal de Pernambuco. Recife. 2011.

LÓPEZ PITA, A.; TEIXEIRA, P. F.; CASAS, C.; UBALDE, L.; ROBUSTÉ, F. Evolution of track geometric quality in high-speed lines: ten years experience of the Madrid-Seville line. Proc. Inst. Mech. Eng., 221(F2), 147-155. 2006.

LOTTMAN, R. Practical laboratory measurement and application of stiffness or resilient properties of soils and granular base materials for Idaho flexible pavement. Idaho flexible pavement design procedure. Final Report. Division of Highways. Idaho. 1976.

LU, N.; LIKOS, W. Unsaturated soil mechanics. v. 19. 2004.

MACHADO, S. L.; ZUQUETTE, L. V. Transporte de massa e mecanismos de retenção em solos não saturados. V Simpósio Brasileiro de Solos Não Saturados. 2004.

MACIEL, F. J. Estudo da geração, percolação e emissão de gases no aterro de resíduos sólidos da Muribeca/PE. Dissertação de mestrado. Universidade Federal de Pernambuco. Recife. 2003.

MARIANO, M. O. H. Avaliação da retenção de gases em camadas de cobertura de aterros de resíduos sólidos. Tese de doutorado. Universidade Federal de Pernambuco. Recife. 2008.

MARINHO, F. A. M. A técnica do papel filtro para medição de sucção. Encontro sobre Solos Não Saturados, Porto Alegre, Brasil, pp.112-125, 1995.

MARINHO, F. A. M. Medição de sucção em solos. In: Simpósio Brasileiro de solos não saturados, 3, Rio de Janeiro, 373-397. 1997.

MARINHO, F. A. Shrinkage behaviour of some plastic soils. PhD. Thesis. Imperial College. London. 1994. 
MASSAD, F. Propriedades dos solos à luz de sua gênese: uma reflexão crítica sobre alguns aspectos da experiência brasileira. In: CONGRESSO BRASILEIRO DE MECÂNICA DOS SOLOS E ENGENHARIA DE FUNDAÇÕES, 8. Porto Alegre. São Paulo. ABMS. V.7, p. 7-44. 1986.

MEDINA, J. Mecânica dos pavimentos. Editora UFRJ. Rio de Janeiro. 1997.

MENDES, R. M. Estudo das propriedades geoténicas de Solos Residuais Não Saturados de Ubatuba (SP). Tese de doutorado. Universidade de São Paulo. São Paulo. 2008.

MENEZES, L. C. A.; GUIMARÃES, A. C. R.; CASTRO, C. D. Estudo da influência do perfil da plataforma ferroviária submetida à água da chuva no seu comportamento estrutural. XXXI Congresso Nacional de Pesquisa em Transportes da ANPET. Recife. 2017.

MERHEB, A. H. M. Análise mecânica do lastro ferroviário por meio de ensaios triaxiais cíclicos. Dissertação de mestrado. Escola Politécnica da Universidade de São Paulo, São Paulo. 148 p. 2014.

MOULTON, L. K. Highway subdrainage design, Report No. FHWA-TS-80-224, Federal Highway Administration, 1980.

MRS Logística. https://www.mrs.com.br/empresa, acesso em 14/04/2018.

NABAIS, R. J. S. Manual básico de engenharia ferroviária. São Paulo: Oficina de Textos. 2014.

NG, C. W.; ZHOU, C.; YUAN, Q; XU, J. Resilient modulus of unsaturated subgrade soil: experiemental theoretical investigations. Canadian Geotechnical Journal. v. 50. 223-232. 2012.

NG, C. W.; MENZIES, B. Advanced Unsaturated Soil Mechanics and Engineering. Taylor and Francis Group LCC. 2007.

NG, C. W.; PANG, Y. W. Experimental investigations of the soil-water characteristics of a volcanic soil. Canadian Geotechnical Journal, 37, 1252-1264, 2000.

NG, C. W.; WANG, B.; GONG, B. W. A new triaxial apparatus for studying stress effects on soil-water characteristics of unsaturated soils. Proceedings $15^{\text {th }}$ Conference of International Society of Soil Mechanics and Geotechnical Engineering, Istanbul, vol. 1, Balkema, Rotterdam, 611-614, 2001.

NOGAMI, J. S., VILLIBOR, D. F. Identificação expedita dos grupos de classificação MCT para solos tropicais. In: 10ํㅡㄹ Congresso Brasileiro de Mecânica dos Solos e Fundações, Foz do Iguaçu, Anais. Foz do Iguaçu, ABMS, Vol.4, p.12931300. 1994.

NOGAMI, J. S., VILLIBOR, D. F. Pavimentação de baixo custo com solos 
lateríticos. São Paulo, 1995.

NOGAMI, J. S., VILLIBOR, D. F. Uma nova classificação de solos para finalidades rodoviárias. In: Simpósio Brasileiro de Solos Tropicais em Engenharia, Rio de Janeiro, Anais... Rio de Janeiro: COPPE UFRJ. v. 1. p. 30-41. 1981.

OLIVEIRA, O. M. Estudo sobre a resistência ao cisalhamento de um solo residual compactado não saturado. Tese (doutorado) - Escola Politécnica da Universidade de São Paulo - Departamento de Engenharia de Estruturas e Fundações, São Paulo, 2004.

PAIVA, C.; FERREIRA, M.; FERREIRA, A. Ballast drainage in Brazilian railway infrastructures. Construction and Building Materials, v. 92, p. 58-63, 2015.

PARK, K. D.; FLEMING, I. R. Evaluation of a geosynthetic capillary barrier. Geotextile and Geomembranes. University of Saskatchewan. Canada. Vol. 24. P. 6471. 2006.

PEIXOTO, J. P.; KETTANI, M. A. The control of the water cycle. Sci. Am., 228, 4661.1973.

PERERA, Y.; ZAPATA, C.; HOUSTON, W.; HOUSTON, S. Prediction of the soil water characteristic curve based on grain-size-distribution and index properties. Advances in Pavement Engineering, Geotechnical Special Publication, 130, 49-60, 2005.

PHILLIP, A. W. The relationship between resilient modulus and soil suction of fine-grained soil in pavement design. Tese de Doutorado. University of South Australia. 1996.

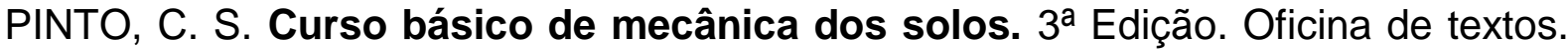
São Paulo. 2006.

PIRES, J. J. Integrated maintenance model for heavy haul tracks, Ph.D. Thesis, École Polytechnique Fédérale de Lausanne, Suisse, 2015.

PROFILLIDIS, V. A. Raiway management and engineering. 2006.

RAHARDJO, H.; MELINDA, F.; LEONG, E. C.; REZAUR, R. B. Stiffness of a compacted residual soil. Engineering Geology, v. 120, n. 1-4, p. 60-67, 2011.

RIANNA, G.; PAGANO, L.; URCIUOLI, G. Investigation of soil-atmosphere interaction in pyroclastic soils. Journal of Hydrology, v. 510, p. 480-492, 2014.

RICHARDS, L. A. Capillary conduction of liquids through porous mediums. Physics 1, No. 5, 318-333. 1931.

RIDLEY, A. M.; WRAY, W. K. Suction measurement: a review of current theory and practices. Proc. Conf. on Unsaturated Soils, Paris, Alonso and Delage eds, Balkema, Rotterdam, pp. 1293-1322. 1995. 
RODRIGUES, M. R. Influência da sucção no módulo de resiliência do solos típicos de subleito de pavimentos do Rio Grande do Sul. Dissertação de Mestrado. Escola de Engenharia. Universidade Federal do Rio Grande do Sul. Porto Alegre. 1997.

ROSSI, M.; DONNINI, M. Estimation of regional scale effective infiltration using an open source hydrogeological balance model and free/open data. Environmental Modelling and Software, v. 104, p. 153-170, 2018.

RUSHTON, K. R.; GHATAORA, G. Design for efficient drainage of railway track foundations. Proceedings of the Institution of Civil Engineers. Transport, 167(1), n. 3. 2014.

SANT'ANNA-NETO, J. L. A Gênese da climatologia no Brasil: o despertar de uma ciência. Geografia, v. 28, n. 1, p. 5-27, 2003.

SELIG, E. T.; WATERS, J. M. Track geotechnology and substructure management. 1994.

SHOCK, C.; BARNUM, J.; SEDDIGH, M. Calibration of watermark soil moisture sensors for irrigation management. In: Proc. Irrigation Assn., Intl. Irr. Show. P. 139146. 1998.

SILVA, L. F. M. Fundamentos teóricos-experimentais da mecânica dos pavimentos ferroviários e esboço de um sistema de gerência aplicado à manutenção da via permanente. Tese de Doutorado, COPPE/UFRJ. Rio de Janeiro, 333 p. 2002.

SOUKEF JUNIOR, A.; BUSNARDO FILHO, A. The São Paulo Railway São Paulo: Threatened Railway Heritage in Brazil. Furnace Journal Issue 3, v.1, p. 55-65, 2016.

SPADA, J. L. G. Uma abordagem de mecânica dos pavimentos aplicada ao entendimento do mecanismo de comportamento tensão-deformação da via férrea. D.Sc., COPPE/UFRJ, Rio de Janeiro. 2003.

STUERMER, M.M. Estudo da capacidade de retenção de água em um solo residual compactado. - Dissertação de Mestrado, EPUSP, 122 p. 1998.

SUZUKI, C. Y.; AZEVEDO, A. M.; KABBACH, F. I. Drenagem subsuperficial de pavimentos. Oficina de textos. 2013.

TAKEDA, M. C. A influência da variação da umidade pós-compactação no comportamento mecânico de solos de rodovias do interior Paulista. Tese de doutorado. São Carlos. 2006.

TENNAKOON, N.; INDRARATNA, B.; RUJIKIATKAMJORN, C.; NIMBALKAR, S. The role of ballast fouling characteristics on the drainage capacity of rail substructure, ASTM Geotechnical Testing Journal, 35(4), 1-12, 2012.

TEROS 21 MANUAL. www.publications.metergroup.com (acesso em 25 Janeiro de 
2018).

THOMPSON, R. B.; GALLARDO, M.; AGILERA, T.; VALDEZ, L. C.; FERNANDEZ, M. $D$. Evaluation of watermark sensor for use with drip irrigated vegetable crops. Irrig Sci 24:185-202. 2006.

TREVIZO, M. C. FAST/HAL ballast and subgrade experiments. AAR Report R-788 FRA/ORD-91/10. Association of American Railroads Transportation Test Center Pueblo, Colorado. 1991.

TUCCI, C. Hidrologia - ciência e aplicação. Editora da Universidade, ABRH, Porto Alegre. 2000.

USMAN, K.; BURROW, M.; GHATAORA, G. Railway track subgrade failure mechanisms using a fault chart approach. The 5th International Conference of Euro Asia Civil Engineering Forum (EACEF-5). 2015.

VAN GENUCHTEN, M. T. A closed-form equation for redicting the Hhydraulic conductivity of unsaturated soils. Soil Science Society of America Journal. 44. 1980.

VANAPALLI, S. K.; FREDLUND, D. G.; PUFAHL, D. E. The influence of soil structure and stress history on the soil-water characteristics of a compacted till. Géotechnique, 49(2): 143-159, 1999.

VIRGILIIS, A. L. C. Procedimentos de projeto e execução de pavimentos permeáveis visando retenção e amortecimento de picos de cheias. Dissertação de mestrado, University of São Paulo, São Paulo, 2009.

WILSON, G. W.; FREDLUND, D. G; BARBOUR, S. L.; The effect of soil suction on evaporative fluxes from soil surfaces. Canadian Geotechnical Journal, v. 34, n. 1, p. 145-155. 1997.

WNEK, M. A.; TUTUMLUER, E.; MOAVENI, M.; GEHRINGER, E. Investigation of aggregate properties influencing railroad ballast performance, Transportation Research Record: Journal of the Transportation Research Board, v. 2374, 180-189, 2013.

YAGHOUBI, E.; DISFANI, M.; ARULRAJAH, A.; KODIKARA, J. Impact of Compaction Methods on Resilient Response of Unsaturated Granular Pavement Material. Advances in Transportation Geotechnics. V. 143, pp. 323-330, 2016.

YANG, S. et al. Suction-crontrolled laboratory test on resilient modulus of unsaturated compacted subgrade soils. Geotechnical and Geoenvironmental Engineering, v. 134, n. September, p. 1375-1385, 2008.

YANG, S.; HUANG, W.; TAI, Y. Variation of resilient modulus with soil suction for compacted subgrade soils. Transportation Research Record: Journal of the Transportation Research Board, No. 1913, Transportation Research Board of the National Academies, Washington, D.C., pp. 99-106. 2005. 